\title{
Niże \\ śródziemnomorskie jako czynnik klimatu Polski
}


卷 
Jan Degirmendžić, Krzysztof Kożuchowski

Niże

śródziemnomorskie

jako czynnik

klimatu Polski 
Jan Degirmendžić - Uniwersytet Łódzki, Wydział Nauk Geograficznych

Katedra Geografii Fizycznej, 90-139 Łódź, ul. Narutowicza 88

Krzysztof Kożuchowski - Instytut Nauk Leśnych, Uniwersytet Łódzki

Filia w Tomaszowie Mazowieckim, 97-200 Tomaszów Mazowiecki, ul. Konstytucji 3 Maja 65/67

RECENZENT

Rajmund Przybylak

REDAKTOR INICJUJĄCY

Iwona Gos

SKŁAD I ŁAMANIE

Tomasz Minkiewicz

KOREKTA TECHNICZNA

Leonora Wojciechowska

PROJEKT OKŁADKI

Stämpfli Polska Sp. z o.o.

Zdjęcie wykorzystane na okładce: (C) Shutterstock.com

Wydrukowano z gotowych materiałów dostarczonych do Wydawnictwa UŁ

(C) Copyright by Authors, Łódź 2016

(C) Copyright for this edition by Uniwersytet Łódzki, Łódź 2016

Wydane przez Wydawnictwo Uniwersytetu Łódzkiego

Wydanie I. W.07500.16.0.K

Ark. druk. 10,375

ISBN 978-83-8088-435-9

e-ISBN 978-83-8088-436-6

Wydawnictwo Uniwersytetu Łódzkiego

90-131 Łódź, ul. Lindleya 8

www.wydawnictwo.uni.lodz.pl

e-mail: ksiegarnia@uni.lodz.pl

tel. (42) 6655863 


\section{Spis treści}

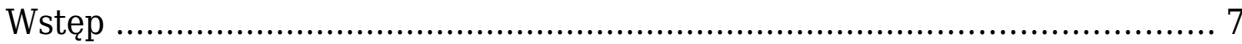

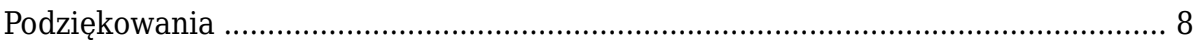

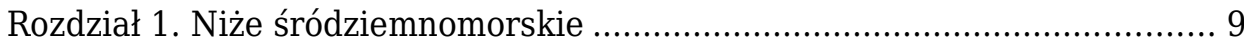

Rozdział 2. Cele opracowania, problemy i hipotezy badawcze .................... 13

Rozdział 3. Dane i metody ….................................................................... 17

Baza danych niżów śródziemnomorskich MEC ……………............................... 17

Parametry charakteryzujące dynamikę niżów ………………………………….... 18

Klasyfikacja trajektorii ....................................................................................... 18

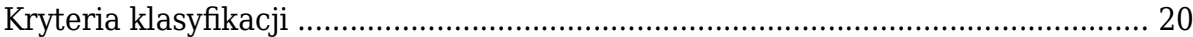

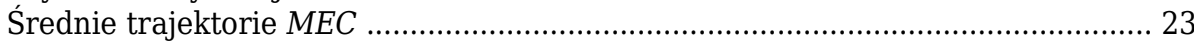

Zmiany sezonowe liczby MEC ……………………….................................... 23

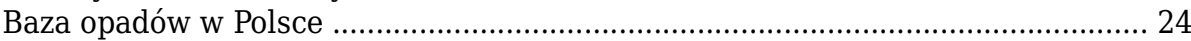

Odcinek opadotwórczy trajektorii ....................................................................... 24

Geneza śródziemnomorska opadu w Polsce .................................................... 26

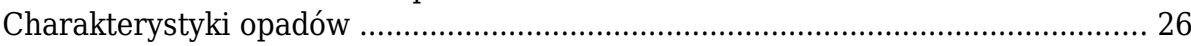

Baza danych wilgotnościowych, termicznych oraz cyrkulacyjnych ...................... 27

Trendy MEC, makrotypów cyrkulacji V-G, opadów oraz zawartości wilgoci w atmosferze .......................................................................................... 29

Czynniki wpływające na opady $M C P$ w Polsce ....................................................... 29

Trajektorie wsteczne mas powietrza …………………….................................... 29

Rozdział 4. Trajektorie ruchu i frekwencja niżów środziemnomorskich nad

Europą Środkowo-Wschodnią ............................................................. 31

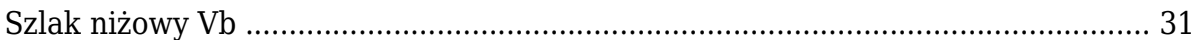

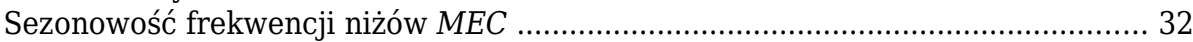

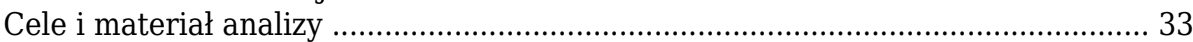

Typy trajektorii ruchu niżów MEC ........................................................................ 33

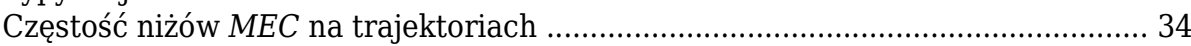

Zmiany sezonowe frekwencji niżów ............................................................ 37

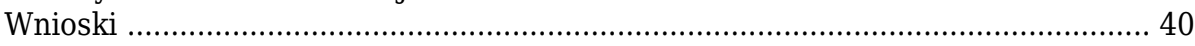

Rozdział 5. Niże śródziemnomorskie i opady w Polsce ............................... 41

Opady o genezie śródziemnomorskiej w Polsce ...................................................... 41

Materiał analizy opadów o genezie śródziemnomorskiej ...................................... 42

Udział opadów o genezie śródziemnomorskiej w całkowitych sumach opadów .... 45

Obfitość opadów o genezie śródziemnomorskiej .................................................... 48

Sezonowe zmiany opadów o genezie śródziemnomorskiej ...................................... 54

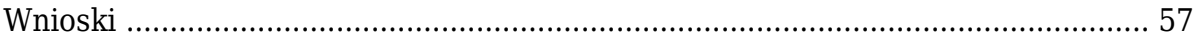


Rozdział 6. Szlaki niżów śródziemnomorskich a rozkład opadów $M C P$

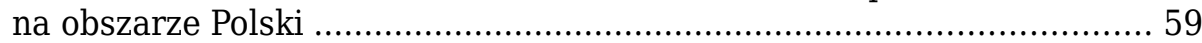

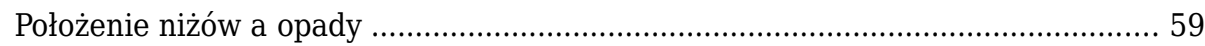

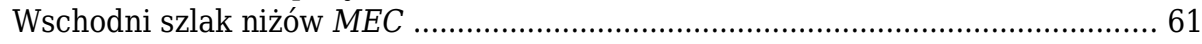

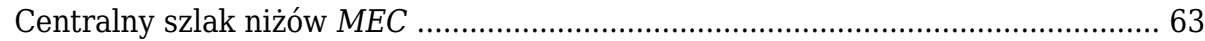

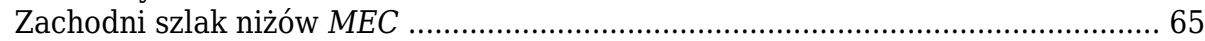

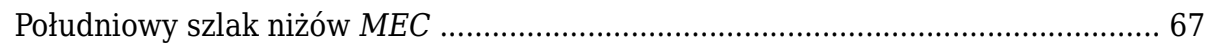

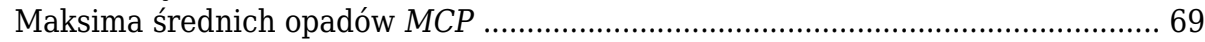

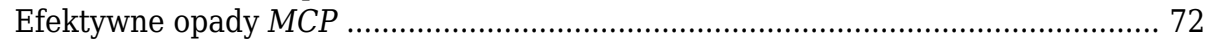

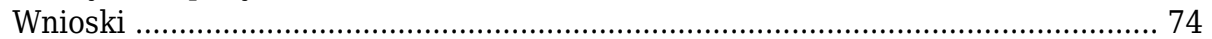

Rozdział 7. Niże śródziemnomorskie, zawartość wilgoci w atmosferze

i temperatura powietrza ............................................................. 75

„Precipitable water" .................................................................................... 75

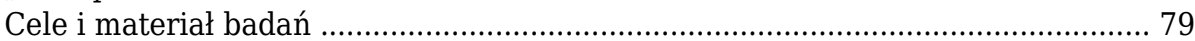

Szlaki niżów $M E C$, zawartość wilgoci w atmosferze i opady w Polsce ................... 81

Ekstremalne opady i zawartość wilgoci w atmosferze ........................................... 85

Niże $M E C$ a zawartość wilgoci w atmosferze nad Europą i północnym

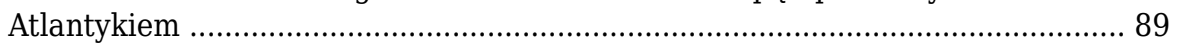

Niże $M E C$, pole temperatury w Europie i nad północnym Atlantykiem

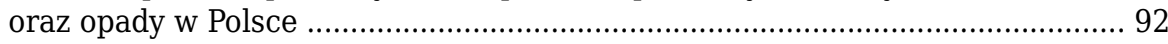

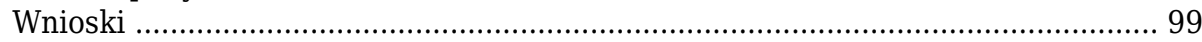

Rozdział 8. Tendencje zmian wieloletnich ............................................... 101

Ocieplenie, cyrkulacja atmosferyczna i opady od połowy XX wieku .................... 101

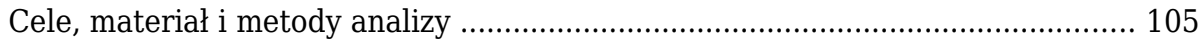

Liczba i cechy niżów śródziemnomorskich w okresie 1958-2008 ........................ 107

Zmiany opadów pochodzenia śródziemnomorskiego …………………………..... 109

Zmiany zawartości wilgoci w atmosferze ....................................................... 112

Makroforma cyrkulacji południkowej E i niże śródziemnomorskie ....................... 113

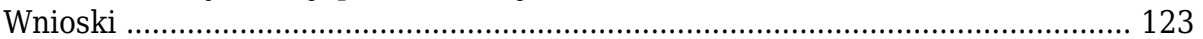

Rozdział 9. Niże śródziemnomorskie a warunki cyrkulacyjne w górnej

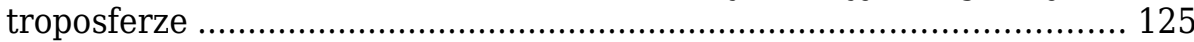

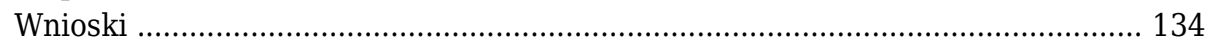

Rozdział 10. Podsumowanie i wnioski ..................................................... 135

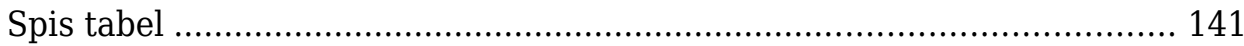

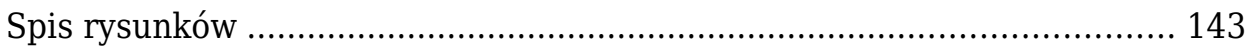

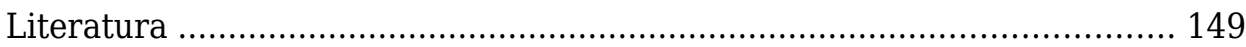

Summary - Mediterranean Cyclones as a Factor of the Climate of Poland 159

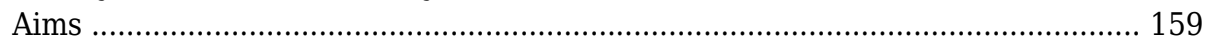

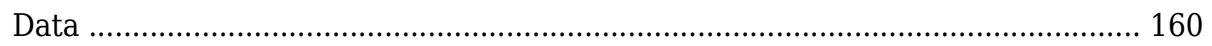

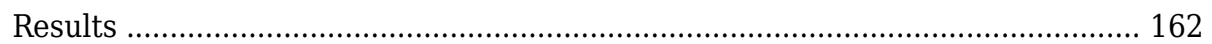


http://dx.doi.org/10.18778/8088-435-9

\section{Wstęp}

Prezentowana tu praca stanowi wynik realizacji projektu badawczego pt. „Współczesne zmiany aktywności niżów śródziemnomorskich jako czynnik ryzyka ekstremalnych zdarzeń hydrometeorologicznych i zmian klimatycznych w Polsce" ${ }^{\prime 1}$. Zebrano w niej wyniki klimatologicznych badań niżów śródziemnomorskich, oddziałujących na warunki klimatyczne w Polsce w latach 1958-2008.

Projekt realizowano w Katedrze Geografii Fizycznej Uniwersytetu Łódzkiego, a cząstkowe wyniki publikowano w artykułach, zamieszczonych w kilku czasopismach naukowych ${ }^{2}$. Treść tych artykułów, po stosownej modyfikacji, wykorzystano także w niniejszej, zbiorczej publikacji. Zawiera ona ponadto inne, jeszcze nie publikowane rezultaty wykonanych badań.

Opracowanie składa się z wprowadzenia, przedstawiającego specyfikę badanych cyklonów - niżów śródziemnomorskich ${ }^{3}$ i odwołującego się m.in. do klasycznego ujęcia tych niżów, wędrujących szlakiem „Vb” nad Europą i zobrazowanego mapą torów niżowych van Bebbera z 1891 roku. Drugi rozdział poświęcono prezentacji celów i zakresu opracowania; przedstawiono problemy i hipotezy badawcze. W kolejnym rozdziale opisano wykorzystane dane i materiały oraz zastosowane metody ich analizy.

W rozdziale 4. zawarto wyniki oceny częstości występowania niżów śródziemnomorskich, jej zmienność sezonową oraz wyróżniono typy szlaków wędrówki niżów nad Europą Środkowo-Wschodnią. Rozdział 5. zawiera ocenę wysokości opadów o genezie śródziemnomorskiej oraz ich udział w całkowi-

1 Grant NCN nr N N306313739.

2 „Acta Universitatis Lodziensis” 2014, „Przegląd Geofizyczny” 2014, 2015, „Quaestiones Geographicae” 2015, „Przegląd Geograficzny” 2015, „Geographia Polonica" 2016 (w druku).

3 Terminów „niże śródziemnomorskie” i „cyklony śródziemnomorskie” - na ogół ze względu na stylistykę tekstu - używano wymiennie, bowiem oba odnoszą się do przedmiotu opracowania: oznaczają odpowiednio układ pola barycznego i cyrkulację atmosferyczną w tym polu. 
tych sumach opadów w Polsce. W rozdziale 6. przedstawiono m.in. obraz rozmieszczenia opadów pochodzenia śródziemnomorskiego w Polsce i ich związek z torami ruchu niżów. Rozdział 7. zawiera ocenę zawartości wilgoci („precipitable water") w warunkach działalności niżów śródziemnomorskich na obszarze Polski oraz ocenę wpływu tej zawartości na wysokość opadów. Pokazano także strukturę pól temperatury i wilgotności w Europie związanych z niżami śródziemnomorskimi. Kolejny, 8. rozdział prezentuje wyniki badania wieloletnich zmian częstości i aktywności niżów śródziemnomorskich, zmian opadów pochodzenia śródziemnomorskiego w Polsce i zmian zawartości wilgoci w atmosferze. Przedstawiono także m.in. próbę wyjaśnienia tych zmian, wskazując na równoległą ewolucję makroform cyrkulacji atmosferycznej. W rozdziale 9 przedstawiono wyniki analizy cyrkulacji atmosferycznej w górnej troposferze (na poziomie $300 \mathrm{hPa}$ ), która najwyraźniej kształtuje aktywność badanych niżów i potwierdza dywergencyjną teorię cyklogenezy.

W podsumowaniu (rozdz. 10) zebrano najważniejsze wyniki, w tym m.in. wniosek, że wykonane analizy statystyczne nie potwierdziły popularnej hipotezy o rosnącej częstości zdarzeń ekstremalnych (tu: częstości i aktywności niżów $\mathrm{Vb}$ ) w epoce postępującego ocieplenia klimatu.

\section{Podziękowania}

Podstawową bazę danych, wykorzystaną w pracy, stanowiły serie dobowych sum opadów oraz wartości średniej temperatury powietrza w Polsce - uzyskano je dzięki uprzejmości Instytutu Meteorologii i Gospodarki Wodnej w Warszawie.

Autorzy niniejszego opracowania składają serdeczne podziękowania dr Żanecie Papiernik i dr. Markowi Walischowi za pomoc w przygotowaniu i uzupełnieniu bazy danych o niżach śródziemnomorskich. W szczególności dziękujemy Tomkowi Minkiewiczowi za weryfikację bazy „Northern Hemisphere Cyclone Locations and Characteristics" opublikowanej przez National Snow and Ice Data Center, University of Colorado oraz pomoc edytorską i graficzną w przygotowaniu maszynopisu do druku. Mgr Ani Szymańskiej oraz dr. Aleksandrowi Szmidtowi dziękujemy za pomoc w przygotowaniu map średnich trajektorii niżów śródziemnomorskich.

Wyrazy podziękowania kierujemy również do prof. dr hab. Andrzeja Marsza za udostępnienie bazy danych o makrotypach cyrkulacji Vangengeima-Girsa. Dane o zawartości wilgoci w atmosferze nad Polską zweryfikowano, porównując je z serią skonstruowaną przez prof. dr hab. Joannę Wibig. 


\section{Rozdział 1 Niże śródziemnomorskie}

Niże śródziemnomorskie nad Europą Środkowo-Wschodnią wyróżniają się specyficzną genezą, a przede wszystkim charakterystyczną trajektorią swojego ruchu znad basenu Morza Śródziemnego.

W basenie śródziemnomorskim zlokalizowana jest strefa cyklogenezy, dzięki której przeważająca część układów cyklonalnych występujących na tym obszarze (niżów śródziemnomorskich) ma autochtoniczny charakter: wg Martyn (2000) spośród średniej rocznej liczby 76 cyklonów tam występujących, aż 69 powstaje nad Morzem Śródziemnym, z czego kolejna większość (52 niże) tworzy się nad Zatoką Genueńską - są to tzw. „niże genueńskie”.

Działalność cyklonalna nad Morzem Śródziemnym rozwija się w chłodnej połowie roku w związku z oddziaływaniem śródziemnomorskiej gałęzi frontu polarnego. Bartoszek (2006) wspomina jednak o dużej liczbie niżów termicznych, powstających w ciepłej połowie roku i wiąże ten fakt „z warunkami fizyczno-geograficznymi Niziny Padańskiej”. Dodaje również, że na wiosnę wiele niżów śródziemnomorskich powstaje w Afryce, na południe od Atlasu. Obszarem cyklogenezy są także wybrzeża Półwyspu Iberyjskiego. Letnie niże mają najczęściej stacjonarny charakter, co potwierdza ich termiczną genezę.

Pewna część cyklonów śródziemnomorskich wędruje ku północy, obejmując swym zasięgiem Europę Środkowo-Wschodnią. Ta właśnie grupa cyklonów stanowi przedmiot niniejszego opracowania i w tym znaczeniu piszemy dalej o niżach śródziemnomorskich (cyklonach śródziemnomorskich), oznaczając je akronimem MEC (Mediterranean European Cyclones).

Układy cyklonalne, przemieszczające się nad Europą wędrują najczęściej z zachodu na wschód szlakami, które stanowiły przedmiot wielu badań klimatologicznych, zapoczątkowanych pracami W. Köppena (1882) i van Bebbera (1891). Wśród trajektorii cyklonów europejskich, na mapie van Bebbera wyróżnia się szlak $\mathrm{Vb}$ (Zugstrasse $\mathrm{Vb}$ ), inaczej niż pozostałe, biegnący południkowo przez Europę Środkowo-Wschodnią od Adriatyku aż do granic Finlandii 
(rys. 1.1). Osobliwa trajektoria i obszar cyklogenezy są przyczyną istotnej roli, jaką odgrywają cyklony, przemieszczające się szlakiem Vb w kształtowaniu warunków klimatycznych, a zwłaszcza wielkości opadów atmosferycznych w Europie Środkowo-Wschodniej.

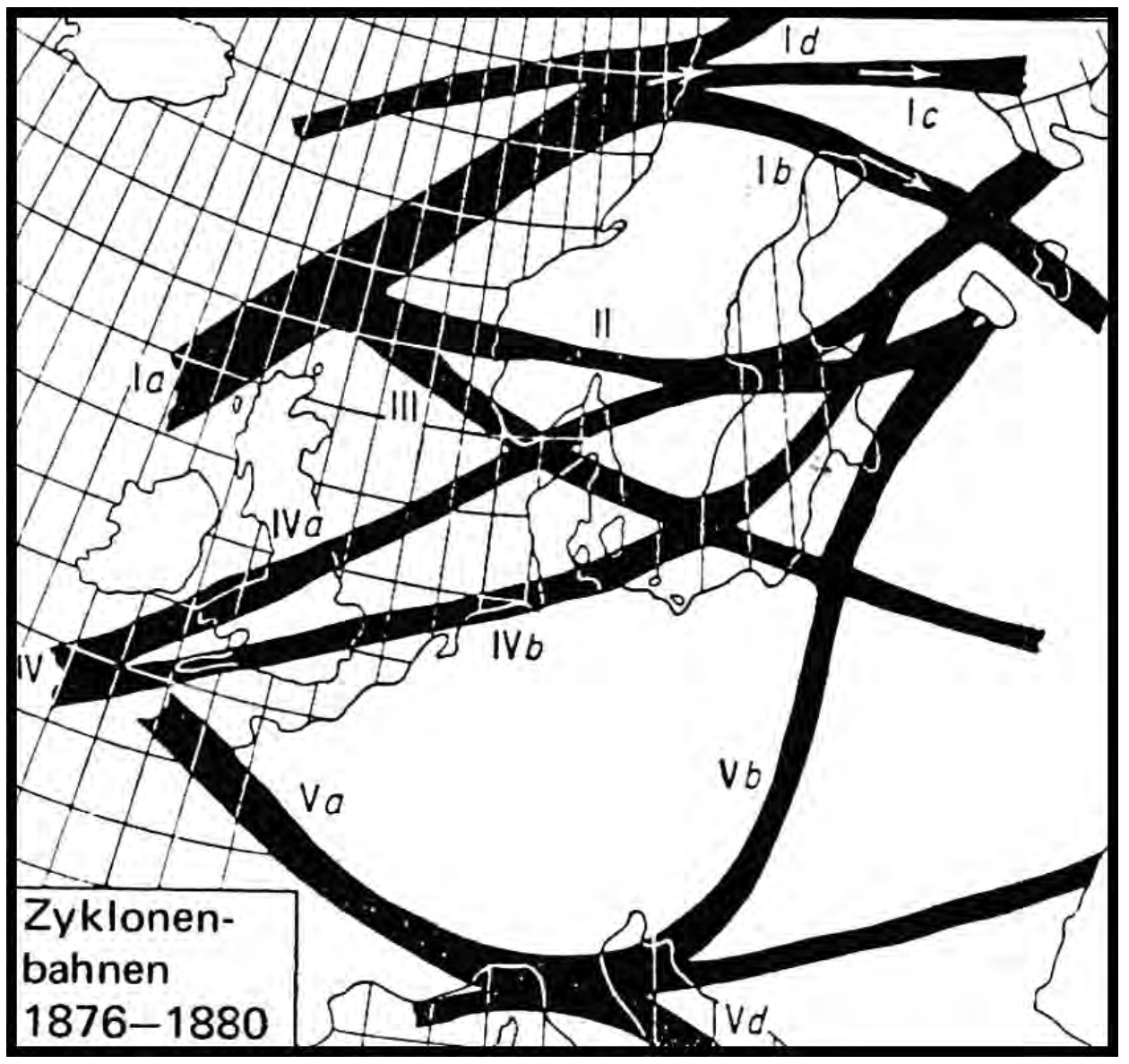

Rys. 1.1. Szlaki niżowe w Europie (wg van Bebbera, 1891)

Mudelsee i in. (2004) podkreślają, że Zugstrasse Vb stanowi nadal aktualne narzędzie, umożliwiające śledzenie warunków tworzenia się rozlewnych opadów i powodzi w Europie Środkowej. Zaprezentowana przez tych autorów historia powodzi w dorzeczach Łaby i Odry w ciągu ubiegłych 500 lat jest przykładem wnikliwych studiów tego zagadnienia. Układy baryczne na szlaku $\mathrm{Vb}$ powodują powodzie albo śnieżyce w Polsce i krajach sąsiednich. Już Hann (1906) opisywał „burze śnieżne”, które przeszły nad Wiedniem i wschodnią 
częścią Niemiec (czyli zapewne i nad zachodnią częścią Polski) na wiosnę w 1903 i w 1905 roku i powiązał je z niżami śródziemnomorskimi.

Ten sam badacz stwierdził, że w latach 1876-1889 cyklony na szlaku Vb stanowiły około 15\% wszystkich cyklonów występujących nad Europą.

Według Bielec-Bąkowskiej (2010) ponad 10\% głębokich cyklonów, występujących nad Polską reprezentują układy, przemieszczające się znad Morza Śródziemnego szlakiem T7, który odpowiada wyróżnionemu przez van Bebbera (1891) szlakowi Vb (rys. 1.2).

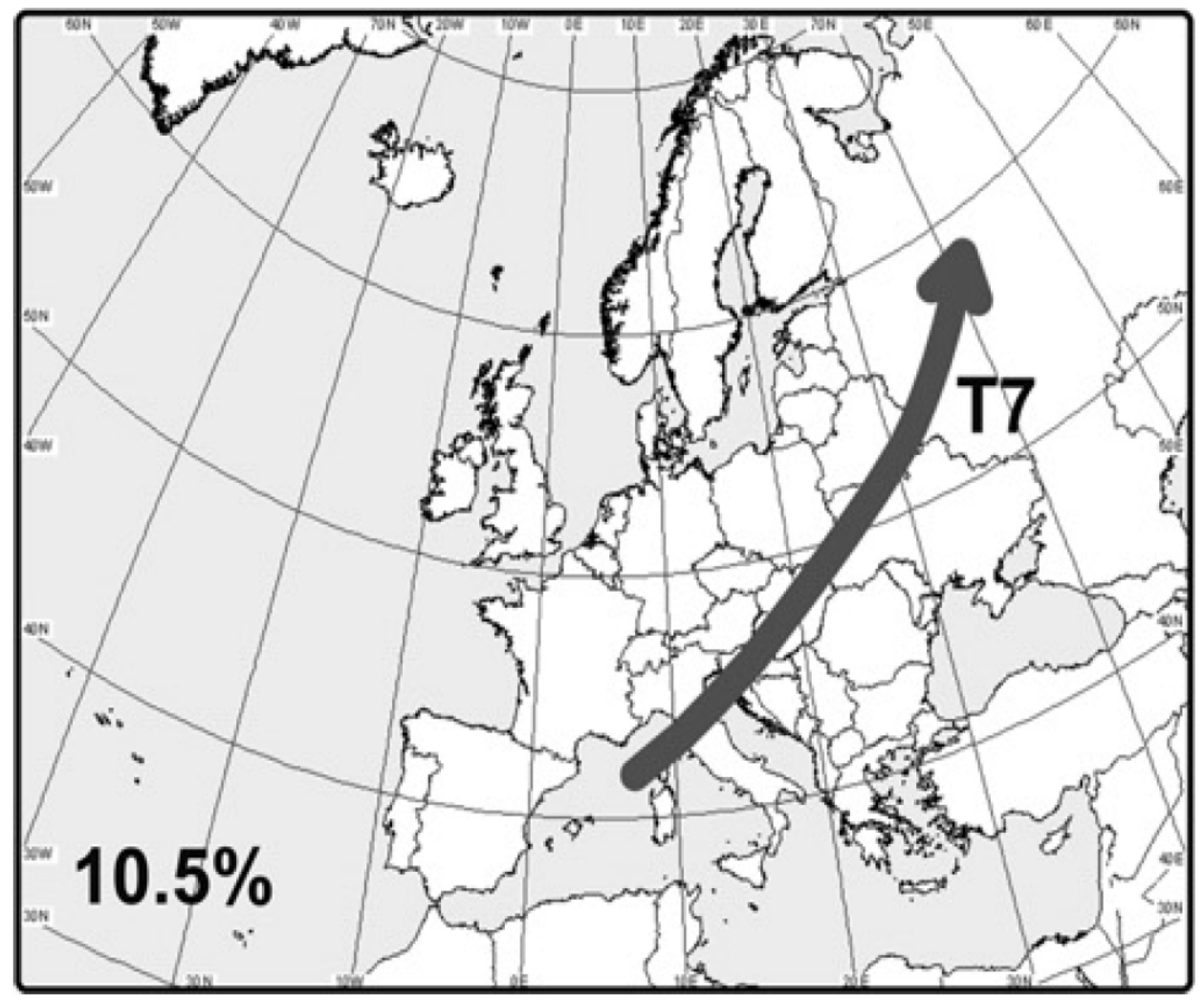

Rys. 1.2. Szlak niżowy T7 i częstość występowania głębokich niżów na tym szlaku (wg Bielec-Bąkowskiej, 2010)

Niże śródziemnomorskie przemieszczają się w kierunku Europy Środkowo-Wschodniej podczas kształtowania się południkowych form cyrkulacji w środkowej i górnej troposferze. „Układy powstające nad północną częścią Włoch wędrują niemal wzdłuż osi prądu strumieniowego, przecinają Nizinę Węgierską i docierają do Karpat Wschodnich" (Bartoszek, 2006). 
Ulbrich i in. (2003), którzy analizowali warunki, towarzyszące powodzi w dorzeczu Łaby w 2002 r. ustalili, że czynnikami aktywizującymi niże śródziemnomorskie są zatoka w polu powierzchni izobarycznej $300 \mathrm{hPa}$ nad zachodnią Europą, silna dywergencja w pobliżu tropopauzy oraz znaczne kontrasty termiczne uczestniczących $\mathrm{w}$ południkowej wymianie mas powietrznych.

Mudelsee i in. (2004) sytuacje baryczne odpowiadające położeniu niżów na szlaku $\mathrm{Vb}$ zakwalifikowali do typu cyrkulacji „Troglage Mitteleuropa” (TrM), który oznacza bruzdę nad Europa Środkową.

Spostrzeżenia te pozwalają uznać, iż poza „geograficznymi” czynnikami cyklogenezy w basenie Morza Śródziemnego, takimi jak termiczne oddziaływania ciepłego podłoża akwenów oraz orografia, wędrówka niżów $M E C$ nad kontynent zależy od cyrkulacji górnotroposferycznej. Ma tu zastosowanie teoria dywergencyjna $R$. Scherhaga - Ulbrich i in. (2003) wskazują na istnienie strefy silnej dywergencji nad układami $M E C$ w warstwie 500-250 hPa. Geneza i aktywność tych niżów jest pochodną chwiejności baroklinowej, kształtującej się wskutek południkowej wymiany mas powietrza. Generalnym czynnikiem cyrkulacyjnym jest tu położenie i amplituda fali długiej w środkowej i górnej troposferze. Dolina tej fali, umiejscowiona nad środkową Europą, umożliwia kształtowanie się systemu cyrkulacyjnego, sprzyjającego wędrówce niżów szlakiem $\mathrm{Vb}$. Fronty atmosferyczne, związane z tymi niżami i bezpośrednio oddziałujące na panującą $\mathrm{w}$ ich zasięgu pogodę, w tym szczególnie wysokie opady, są przede wszystkim efektem obecności i rozwoju północnej adwekcji chłodnego powietrza i południowej adwekcji mas ciepłych odpowiednio po zachodniej i wschodniej stronie bruzdy „TrM”.

Niże o genezie śródziemnomorskiej stanowią pewną osobliwość klimatu Polski; pojawiają się nie często, ale znacząco wpływają na zmienność elementów klimatu, przede wszystkim na wysokość opadów atmosferycznych. Niektóre epizody opadowe, powstające $\mathrm{w}$ związku z działalnością niżów śródziemnomorskich, zwłaszcza w okresie letnim, odznaczają się wyjątkową obfitością i są odpowiedzialne za najwyższe notowane w Polsce sumy opadów. $\mathrm{Z}$ tego względu niże śródziemnomorskie można uznać za czynnik, generujący ekstremalne zjawiska meteorologiczne w Polsce. 


\section{Rozdział 2 \\ Cele opracowania, problemy i hipotezy badawcze}

Wstępnym celem klimatologicznej analizy działalności niżów śródziemnomorskich w Polsce jest zdefiniowanie przedmiotu badań. W tym zakresie określono pewien typ cyrkulacji atmosferycznej ${ }^{4}$ - niż śródziemnomorski w Europie Środkowo-Wschodniej (MEC), czyli układ cyklonalny przemieszczający się trajektorią, pierwotnie obejmującą basen Morza Śródziemnego i docierający nad stosownie zdefiniowany obszar Europy (patrz: rozdz. 3). Niżom MEC przyporządkowano - jako skutek ich aktywności - opady pochodzenia śródziemnomorskiego w Polsce (Mediterranean Cyclonal Precipitation - MCP). Sposób wydzielenia tego typu opadów przedstawiono także w rozdz. 3. Kalendarz występowania $M E C$ oraz opadów $M C P$ wraz z ich charakterystykami stanowi w ten sposób zasadniczą, empiryczną podstawę i materiał niniejszego opracowania.

W polskiej literaturze klimatologicznej nie mamy dotąd syntetycznego opisu niżów MEC. Wzmianki o nich pojawiały się wprawdzie w wielu pracach, a najpełniejszą syntezę informacji o niżach śródziemnomorskich zawiera artykuł Bartoszka (2006). Niemniej, nie wiemy jeszcze jak często MEC pojawiają się w Europie Środkowo-Wschodniej, jakie są ich faktyczne trajektorie ruchu (czy „klasyczna” droga Vb jest jedyna?), czy częstość występowania niżów MEC ma sezonowy charakter i wreszcie - czy mamy do czynienia z wieloletnimi zmianami frekwencji $M E C$ ?

4 „Typ MEC” nie znajduje odpowiednika w istniejących klasyfikacjach typów cyrkulacji atmosferycznej (Kaszewski, 2012). W szczególności nie można go utożsamiać ze śródziemnomorskim typem cyrkulacji (Śr.), który na podstawie analizy składowych głównych pola izopowierzchni 500 hPa wyróżniła Wibig (2001). MEC stanowi jedynie specyficzną postać wspomnianego w rozdz. 1. typu TrM z klasyfikacji „Grosswetterlagen Europas" (Hess i Brezowsky, 1952). 
Szereg pytań dotyczy także opadów pochodzenia śródziemnomorskiego, ich ogólnej wysokości, udziału w całkowitej sumie opadów na obszarze Polski, rozkładu przestrzennego i zmian wieloletnich. Należałoby ponadto sprawdzić, czy zasadna jest teza, iż o znacznej wysokości opadów MCP decydują zasoby wilgoci w powietrzu uczestniczącym w cyrkulacji cyklonalnej MEC. Istotnym zagadnieniem jest ponadto struktura termiczna i wilgotnościowa $M E C$ : czy ze względu na obszar cyklogenezy i osobliwy tor wędrówki niże te wyróżniają się też charakterystycznymi, specyficznymi cechami?

Opracowanie niniejsze ma na celu uszczegółowienie klimatologicznego opisu niżów $M E C$ - ocenę częstości ich występowania oraz zmienności sezonowej i wieloletniej. Celem pracy jest także klimatologiczna charakterystyka opadów pochodzenia śródziemnomorskiego w Polsce.

W ramach prezentowanego opracowania zweryfikowano kilka hipotez badawczych:

1) niże śródziemnomorskie należą do rzadkich układów cyrkulacyjnych w Europie Środkowej;

2) częstość występowania $M E C$ charakteryzuje się sezonową zmiennością;

3) niże $M E C$ docierają do Europy Środkowej i Środkowo-Wschodniej charakterystycznymi, ale różnymi szlakami;

4) opady pochodzenia śródziemnomorskiego w Polsce wyróżniają się dużą obfitością i stanowią znaczącą część całkowitej sumy opadów;

5) rozkład przestrzenny opadów $M C P$ na obszarze Polski zależy od trajektorii przemieszczania się $M E C$;

6) opady $M C P$ formują się w warunkach podwyższonej, ponadprzeciętnej zawartości wilgoci w atmosferze;

7) układy $M E C$ i związane $\mathrm{z}$ nimi wysokie opady pojawiają się w okresach panowania południkowych makroform cyrkulacji atmosferycznej;

8) $M E C$ i $M C P$ należą do klasy ekstremalnych zjawisk hydrometeorologicznych, a ich częstość i intensywność wzrasta wraz z postępującym globalnym ociepleniem klimatu.

Rozpatrzenie hipotez (1-6) powinno doprowadzić nie tylko do niekiedy oczywistych rozstrzygnięć w kategoriach „tak/nie”, ale przede wszystkim do ilościowej oceny formułowanych wniosków.

Hipotezy (7) i (8) mają w badaniach klimatologicznych szczególne znaczenie ze względu na prognostyczny aspekt ich treści.

(7) Makroformy cyrkulacyjne wykazują tendencję do formowania tzw. epok cyrkulacyjnych - wieloletnich okresów dominującego panowania określonych form cyrkulacji. Mogą to być okresy sprzyjające bądź nie sprzyjające 
wędrówce niżów na szlaku $\mathrm{Vb}^{5}$. Charakter epoki decydować więc może o frekwencji niżów.

(8) Hipoteza o wzrastającej współcześnie częstości i intensywności zjawisk ekstremalnych - w odniesieniu do niżów śródziemnomorskich $M E C$ - jest co najmniej problematyczna. Scenariusze klimatyczne nie są jednoznaczne w kwestii prognozowanej zmiany liczby oraz aktywności niżów śródziemnomorskich. Modele globalnego ocieplenia prognozują przesunięcie się podzwrotnikowego pasa antycyklonów ku wyższym szerokościom geograficznym, co w prostej konsekwencji mogłoby prowadzić do spadku częstości cyklonów śródziemnomorskich. Modele regionalne jednak nie potwierdzają takiego scenariusza. Muskulus i Jacob (2005), na podstawie wyników modelu REMO, przewidują wzrost ogólnej liczby cyklonów w basenie Morza Śródziemnego, szczególnie wyraźnie zaznaczony latem. Jednak w przypadku tylko „głębokich" niżów (< 950 hPa w centrum) obserwuje się spadek ich częstości. Odmienny scenariusz zaprezentowali Anagnostopoulou i in. (2006). Autorzy studiowali aktywność niżów w trzech regionach basenu Morza Śródziemnego: w Zatoce Genueńskiej, nad południowymi Włochami oraz w rejonie Cypru. Według modelu HadAMP3 częstość niżów śródziemnomorskich w okresie 2071-2100 ma się zmniejszyć, ale jednocześnie ma wzrosnąć ich intensywność.

Zarówno wzrost liczby niżów śródziemnomorskich prognozowany przez model REMO oraz/lub wzrost aktywności tych układów prognozowany przez model HadAMP3 może istotnie zmienić reżim anomalii pogodowych w Polsce związanych z niżami Vb.

Rezultaty badań empirycznych, zrealizowanych w ramach prezentowanego tu opracowania, pozwalają na sprawdzenie realizacji modelowych scenariuszy na podstawie analizy trendów, obecnych w seriach czasowych frekwencji niżów MEC i opadów MCP i obejmujących okres 1958-2008.

${ }^{5}$ Począwszy od lat 1980. sprzyjająca niżom Vb makroforma cyrkulacji południkowej „E” (wg klasyfikacji Vangengeima-Girsa) wykazuje regres; można sądzić, że od tego czasu panuje epoka „W+C" i dominują formy strefowe $\mathrm{W}$ i południkowe $\mathrm{C}$ (zob. też rozdz. 8). 



\section{Rozdział 3 Dane i metody}

\section{Baza danych niżów śródziemnomorskich MEC}

W pracy wykorzystano bazę „Northern Hemisphere Cyclone Locations and Characteristics from NCEP/NCAR Reanalysis Data” zawierającą listę układów niskiego ciśnienia rozwijających się nad półkulą północną w okresie od 1.01.1958 r. do 31.12.2008 r. (Serreze, 2009). Jest ona wynikiem zastosowania automatycznej procedury detekcji i śledzenia cyklonów. Pozycje niżów określono w czterech terminach: 00, 06, 12 i 18 UTC. Każde wystąpienie niżu zarchiwizowane $\mathrm{w}$ bazie charakteryzuje:

1) data tego wystąpienia [rok, miesiąc, dzień, godzina];

2) wartość ciśnienia w centrum układu zredukowana do poziomu morza [hPa];

3) wartość lokalnego laplasjanu ciśnienia charakteryzującego intensywność układu [mPa km²];

4) dystans przebyty w ciągu minionych 6 godzin [km];

5) tendencja ciśnienia w centrum niżu za minione $6 \operatorname{godzin}\left[\mathrm{hPa}(6 \mathrm{~h})^{-1}\right]$;

6) szerokość geograficzna środka niżu;

7) długość geograficzna środka niżu;

8) informacja o tym, czy dane wystąpienie niżu stanowi cyklogenezę czy cyklolizę;

9) numer identyfikacyjny niżu, do którego przynależy dana sekwencja wystąpień na mapach terminowych.

W celu wyselekcjonowania cyklonów śródziemnomorskich wędrujących znad Morza Śródziemnego oraz Morza Czarnego i Azowskiego nad Europę Środkową zastosowano dwa kryteria:

1) na dowolnym etapie rozwoju układu cyklonalnego jego centrum znajduje się nad basenami Morza Śródziemnego, Czarnego lub Azowskiego; 
2) w późniejszym etapie rozwoju centrum cyklonu przemieszcza się nad obszarem leżącym nie dalej niż $350 \mathrm{~km}$ od granic Polski.

W ten sposób wyselekcjonowano 351 układów MEC (Mediterranean European Cyclones) spełniających powyższe warunki w latach 1958-2008. Podobną metodę służącą do obiektywnej identyfikacji układów Vb zastosowali Nissen i in. (2013).

\section{Parametry charakteryzujące dynamikę niżów}

Do opisu intensywności cyrkulacji MEC wykorzystano laplasjan ciśnienia obliczony dla centrum układu niżowego. Funkcją laplasjanu ciśnienia jest wirowość geostroficzna niżu ( $\zeta_{g}$ ) (Peixoto i Oort, 1992, s. 44):

$$
\zeta_{g}=\frac{1}{\rho f} \nabla^{2} p
$$

gdzie: $\rho$ - gęstość powietrza, $f$ - parametr Coriolisa, $\nabla^{2} p$ - laplasjan ciśnienia $(p)$ na powierzchni poziomej.

Ponadto analizowano wartości ciśnienia w centrum niżu zredukowane do poziomu morza (CCP - Cyclone Central Pressure) oraz 6-godzinne wartości tendencji ciśnienia w centrum układu $(\Delta \mathrm{p})$. Laplasjan ciśnienia, w odróżnieniu od wartości ciśnienia w centrum niżu, stanowi parametr charakteryzujący intensywność cyklonu w znacznej mierze niezależnie od zmian średniego klimatologicznego pola ciśnienia, w tle którego rozwija się dany niż (Murray i Simmonds, 1991). Pożądana jest więc jednoczesna analiza obu parametrów: tendencji ciśnienia oraz laplasjanu ciśnienia.

\section{Klasyfikacja trajektorii}

Trajektorie niżów śródziemnomorskich MEC pogrupowano w klasy. W procedurze klasyfikacji uwzględniono przebieg trajektorii na odcinku od basenu Morza Śródziemnego lub Morza Czarnego do terytorium Polski wraz z pasem o szerokości $350 \mathrm{~km}$ otaczającym Polskę. Usytuowanie początkowego odcinka trajektorii - od punktu cyklogenezy do punktu wejścia w granice basenu Morza Śródziemnego lub Czarnego nie zostało uwzględnione w procedurze klasyfikacji. Elementem istotnym natomiast było położenie punktu cyklolizy - dalekie lub bliskie względem granic Polski. Niż, który daleko od teryto- 
rium kraju podlegał cyklolizie nie wpływał na pogodę w Polsce w fazie zokludowanej, natomiast mógł oddziaływać w dojrzałej fazie cyklu życiowego. W procedurze klasyfikacyjnej wykorzystano siatkę czterech południków i czterech równoleżników. Wydzielono na tej podstawie sektory: centralny (C), obejmujący obszar Polski, wschodni (E), zachodni (W), północny (N) i południowy (S), a cały obszar 5. sektorów określono umownie jako Europę Środkowo-Wschodnią $\left(45^{\circ} 39^{\prime}-58^{\circ} 11^{\prime} \mathrm{N}, 7^{\circ} 32^{\prime}-30^{\circ} 44^{\prime} \mathrm{E}\right)$. Siatka ta pozwoliła w sposób obiektywny określić orientację trajektorii w przestrzeni i ich przynależność do klas (rys. 3.1).

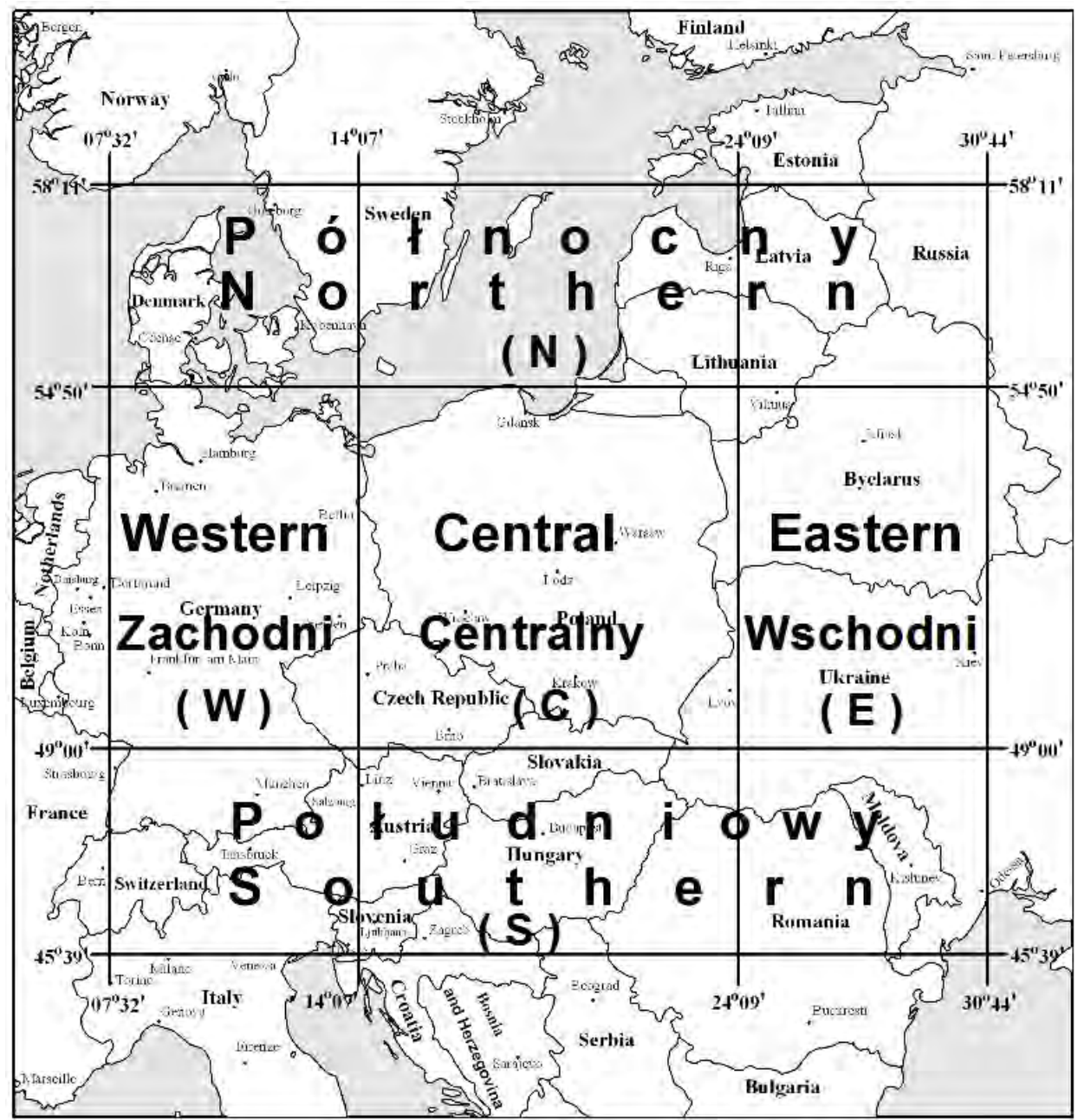

Rys. 3.1. Siatka równoleżników i południków wyznaczająca sektory Europy Środkowo-Wschodniej - W, E, S, N i C (wg Degirmendžića i Kożuchowskiego, 2014) 
W wyniku zastosowania procedury klasyfikacji wyróżniono 12 typów trajektorii wzdłuż, których niże śródziemnomorskie przemieszczają się znad Morza Śródziemnego, Czarnego lub Azowskiego nad środkową lub wschodnią Europę:

- typy wschodnie: E (E1, E2) (trajektorie przebiegające na wschód od Polski, odpowiadają trajektorii Vb van Bebbera);

- typy zachodnie: W (W1, W2) (trajektorie przebiegające na zachód od Polski);

- typy centralne: C $(\mathrm{C} 1, \mathrm{C} 2)$ (trajektorie przechodzące centralnie przez Polskę);

- typy południowe: S (S1, S2) (trajektorie przebiegające na południe od Polski);

- typy czarnomorskie (BS - Black Sea):

- BSS (trajektorie przebiegające na południe od Polski),

-BSN (trajektorie przebiegające na północ od Polski),

- BSE (trajektorie przebiegające na wschód od Polski),

-BSC (trajektorie wchodzące na terytorium Polski).

\section{Kryteria klasyfikacji}

\section{Klasa S1}

Jeżeli układ niskiego ciśnienia od chwili, w której znalazł się w sektorze południowym (zob. rys. 3.1) już go nie opuścił, czyli punkt cyklolizy jest usytuowany również w tym sektorze, to trajektoria takiego niżu klasyfikowana jest jako S1. Niż klasy S1 oddziałuje na Polskę od południa w fazie dojrzałej oraz $\mathrm{w}$ fazie dyssypacji.

\section{Klasa S2}

Jeżeli cyklon znalazł się w sektorze południowym ale w dalszych etapach cyklu życiowego opuścił ten sektor, przy czym nie przekroczył północnej granicy sektora $\left(49^{\circ} 00^{\prime} \mathrm{N}\right)$, to trajektoria takiego układu klasyfikowana jest jako S2. Szlakiem tym przemieszczają się niże oddziałujące na Polskę od południa i będące w większości w fazie dojrzałej cyklu życiowego. Punkt cyklolizy jest oddalony od terytorium Polski, a więc cyklon w fazie dyssypacji nie wpływa na pogodę w Polsce. 


\section{Klasa E1}

Jeżeli cyklon przeszedł przez sektor południowy i znalazł się w sektorze wschodnim przy czym punkt cyklolizy nie przekroczył równoleżnika $58^{\circ} 11^{\prime} \mathrm{N}$ (Gotlandia) oraz umiejscowił się nie dalej na wschód niż południk $30^{\circ} 44^{\prime} \mathrm{E}$ (Odessa) oraz nie dalej na południe niż równoleżnik $45^{\circ} 39^{\prime} \mathrm{N}$ (Triest), to trajektoria takiego układu jest klasyfikowana jako E1. Układy przemieszczające się tym szlakiem oddziałują na warunki pogodowe w Polsce od południowego wschodu oraz wschodu będąc w dojrzałej oraz końcowej fazie rozwoju.

\section{Klasa E2}

Jeżeli cyklon klasy E1 w dalszych etapach rozwoju przekroczył, jeden z dwóch wspomnianych wyżej równoleżników (Triest lub Gotlandia) lub południk Odessy, to taką trajektorię określono jako E2. Niże należące do klasy trajektorii E2 oddziałują na Polskę z południowego-wschodu oraz wschodu, będąc w większości przypadków w dojrzałej fazie cyklu życiowego.

\section{Klasa W1}

Jeżeli cyklon po przejściu przez sektor południowy (lub z jego pominięciem) wszedł w sektor zachodni oraz w dalszych etapach cyklu życiowego nie przekroczył równoleżnika $58^{\circ} 11^{\prime} \mathrm{N}$ (Gotlandia) oraz południka $7^{\circ} 32^{\prime} \mathrm{E}$ (Dortmund) oraz równoleżnika $45^{\circ} 39^{\prime} \mathrm{N}$ (Triest), to taką trajektorię klasyfikujemy jako W1. Układy te oddziałują na Polskę od południowego-zachodu i zachodu znajdując się w większości przypadków w fazie dojrzałej cyklu życiowego oraz $\mathrm{w}$ fazie dyssypacji.

\section{Klasa W2}

Jeżeli układ niżowy po wejściu w sektor zachodni przekroczył następnie ograniczające ten sektor równoleżniki lub południk oraz punkt cyklolizy znalazł się w pewnym oddaleniu od granic Polski to taki typ trajektorii nazywamy W2. Niże przemieszczające się wzdłuż takiej trajektorii oddziałują na Polskę od południowego-zachodu i zachodu będąc w przewadze w dojrzałej fazie rozwoju.

\section{Klasa C1}

Jeżeli niż znalazł się w sektorze centralnym nad Polską i w trakcie dalszego rozwoju nie przekroczył równoleżnika $58^{\circ} 11^{\prime} \mathrm{N}$ (Gotlandia) ani równoleżnika $45^{\circ} 39^{\prime} \mathrm{N}$ (Triest) ani południka $30^{\circ} 44^{\prime} \mathrm{E}$ (Odessa) ani południka $7^{\circ} 32^{\prime} \mathrm{E}$ (Dortmund), to wtedy klasyfikujemy jego trajektorię jako C1. Takie układy 
przechodzą centralnie przez Polskę z południa na północ. Punkty cyklolizy znajdują się w wyznaczonym przez ww. południki i równoleżniki sektorze (większym aniżeli sektor centralny). Układy te przechodzą fazę okluzji i dyssypacji w pobliżu terytorium kraju.

\section{Klasa C2}

Jeżeli niż, który wszedł do sektora centralnego, przekroczył następnie ww. ograniczające południki i równoleżniki to takie trajektorie klasyfikujemy jako C2. Niże typu C2 oddziałują centralnie na Polskę raczej w dojrzałej fazie rozwoju. Ich cykloliza ma miejsce w pewnym oddaleniu od terytorium Polski.

\section{Klasa BSS}

Obejmuje ona takie przypadki niżów, które przemieszczając się znad Morza Śródziemnego nad środkową Europę wchodzą w granice basenu Morza Czarnego lub powstają nad Morzem Czarnym, natomiast ich punkt cyklolizy znajduje się w sektorze południowym.

\section{Klasa BSN}

Klasa dotyczy niżów opisanych w powyższej kategorii, z tą różnicą, że ich punkty cyklolizy usytuowane są na północ od Polski, w sektorze północnym.

\section{Klasa BSE}

Klasa dotyczy niżów wyżej opisanych, z tą różnicą, że ich punkty cyklolizy usytuowane są na wschód od Polski, w sektorze wschodnim lub poza jego granicami.

\section{Klasa BSC}

Klasa dotyczy niżów wyżej opisanych, z tą różnicą, że ich punkty cyklolizy usytuowane są w sektorze centralnym, nad Polską.

W sytuacjach spornych gdy cyklon w kolejnych etapach rozwoju przeszedł przez sektor centralny, a następnie znalazł się w sektorze wschodnim lub zachodnim, to jego trajektorię przyporządkowano do klasy wschodniej (E1 lub E2), centralnej (C1 lub C2) lub zachodniej (W1 lub W2) w zależności od tego, w którym sektorze długość trajektorii jest wyraźnie większa. 


\section{Średnie trajektorie MEC}

Wyznaczono średnie trajektorie w klasach niżów: E, C, W, S oraz w klasach BS (BSN, BSC, BSE, BSS). W tym celu sporządzono rozkłady częstości niżów w poszczególnych klasach w siatce $10^{\circ} \times 5^{\circ}(\lambda, \varphi)$, następnie przeliczono wartości na jeden termin obserwacji i powierzchnię gridu $10^{9} \mathrm{~km}^{2}$. Średnia trajektoria jest linią łączącą maksima rozkładu częstości niżów MEC. Koniec i początek trajektorii określa izolinia o wartości 1 . Kolejne punkty trajektorii wyznaczono z rozdzielczością co $1^{\circ}$ długości i szerokości geograficznej.

\section{Zmiany sezonowe liczby MEC}

Określono zmienność sezonową niżów MEC w latach 1958-2008. Zliczając trajektorie w danym miesiącu, uwzględniono czy trajektoria w całości (od punktu cyklogenezy do punktu cyklolizy), czy częściowo sytuuje się w obrębie miesiąca. W pierwszym przypadku każdą trajektorię liczono raz, w drugim natomiast, zliczono procent określający jaka część cyklu życiowego niżu mieści się w przedziale od początku do końca danego miesiąca. Przeanalizowano zmiany sezonowe częstości wszystkich trajektorii łącznie, każdej klasy trajektorii (E1, E2, W1, W2, S1, S2, C1, C2, BSN, BSE, BSC, BSS) oraz grup trajektorii (E, W, S, C, BS). Scharakteryzowano cykliczność roczną oraz półroczną. Wykorzystując 12-miesięczne szeregi częstości obliczono 12 i 6-miesięczne harmoniki. Następnie wyznaczono współczynniki korelacji między daną harmoniką a wyjściową serią danych. Z uwagi na fakt, że wartość oczekiwana rozkładu współczynników korelacji między losowym szeregiem a harmoniką wyznaczoną na podstawie tego szeregu jest większa od zera, gdyż nie występują ujemne wartości współczynników, zastosowano metodę Monte Carlo do określenia istotności uzyskanych wyników. Symulacja ta składa się z kilku etapów: 1) każdą trajektorię (bez podziału na klasy, w klasie lub w grupie klas) przypisano losowo do danego miesiąca, wykorzystując generator liczb losowych Lahey Fujitsu Fortran 95. Tyle trajektorii podlegało losowaniu ile liczy dana klasa, grupa klas lub cała baza MEC - czyli 351 obiektów, 2) losowe szeregi miesięcznych częstości wykorzystano do obliczenia harmonik, 3) następnie wyznaczono współczynniki korelacji między seriami losowymi a harmonikami, 4) przeprowadzono 100000 losowań w przypadku każdej klasy, grupy klas oraz dla całej bazy $M E C, 5$ ) otrzymano tyleż samo współczynników korelacji wygenerowanych przez proces losowy. Hipoteza alternatywna (H1) 
określona w tym eksperymencie w brzmieniu: „współczynnik korelacji przewyższa zdecydowaną większość współczynników generowanych przez proces losowy" sugeruje zastosowanie testu jednostronnego. Obliczone p-wartości informują o prawdopodobieństwie przewyższenia otrzymanego współczynnika korelacji przy założeniu, że działa jedynie czynnik losowy. P-wartości mniejsze niż 0,05 wskazują na istotne statystycznie cykle w szeregach częstości trajektorii niżów $M E C$.

\section{Baza opadów w Polsce}

Analizę opadów oparto na seriach dobowych sum z 66 stacji meteorologicznych rozmieszczonych równomiernie na terytorium Polski. Serie obejmują lata 1958-2008. Dane uzyskano z Instytutu Meteorologii i Gospodarki Wodnej. Serie sum dobowych z 46 stacji (70\% wszystkich stacji meteorologicznych) nie posiadają braków danych i są jednorodne. Serie z 7 stacji zawierają krótkie luki (<100 dni), co oznacza, że 53 serie opadowe (80\% wszystkich stacji) są prawie kompletne. Serie z dłuższymi lukami (>610 dni) dotyczą stacji rozmieszczonych równomiernie na obszarze Polski. W przypadku braku danych średnią obszarową liczono z mniejszej liczby stacji. Lokalizację stacji pokazano na rysunku 3.2 - zaznaczono także stacje górskie i przedgórskie (13 stacji).

\section{Odcinek opadotwórczy trajektorii}

Aby określić zmiany opadów w Polsce związane z ruchem MEC wzdłuż trajektorii, określono daty wystąpienia tych układów w okręgach o promieniu $250 \mathrm{~km}$ i środkach w kolejnych punktach trajektorii (np. w przypadku szlaku E punkty ponumerowano od 1 do 34).

Średnie obszarowe sumy dobowe opadów (z 66 stacji meteorologicznych w Polsce) wyznaczono na podstawie wartości z dni, kiedy $M E C$ znajdowały się w polu danego okręgu. Procedurę powtarzano dla każdego kolejnego okręgu. Otrzymano tyle wartości średnich obszarowych, ile punktów wyznaczono na danej trajektorii. Dodatkowo, zestawiono wartości maksymalne dla obszaru Polski, wybrane spośród wartości odpowiadających 66 stacjom meteorologicznym. Innymi słowy wartości maksymalne wybrano spośród sum dobowych uśrednionych dla kolejnych stacji z terminów kiedy niże $M E C$ znalazły się 
w granicach danego okręgu. Otrzymano tyle wartości maksymalnych ile punktów znajduje się na danej trajektorii. Wyznaczono opadotwórczy odcinek trajektorii, czyli taki, z którym związane są najwyższe opady w Polsce. Odcinek opadotwórczy jest wyróżniony przez punkty trajektorii, dla których spełnione są dwa kryteria: 1) średni obszarowy opad w Polsce przekracza wartość średnią policzoną dla całej trajektorii (wszystkich punktów trajektorii), 2) maksymalny opad, wybrany spośród 66 stacji w Polsce, przekracza wartość uśrednioną dla całej trajektorii.

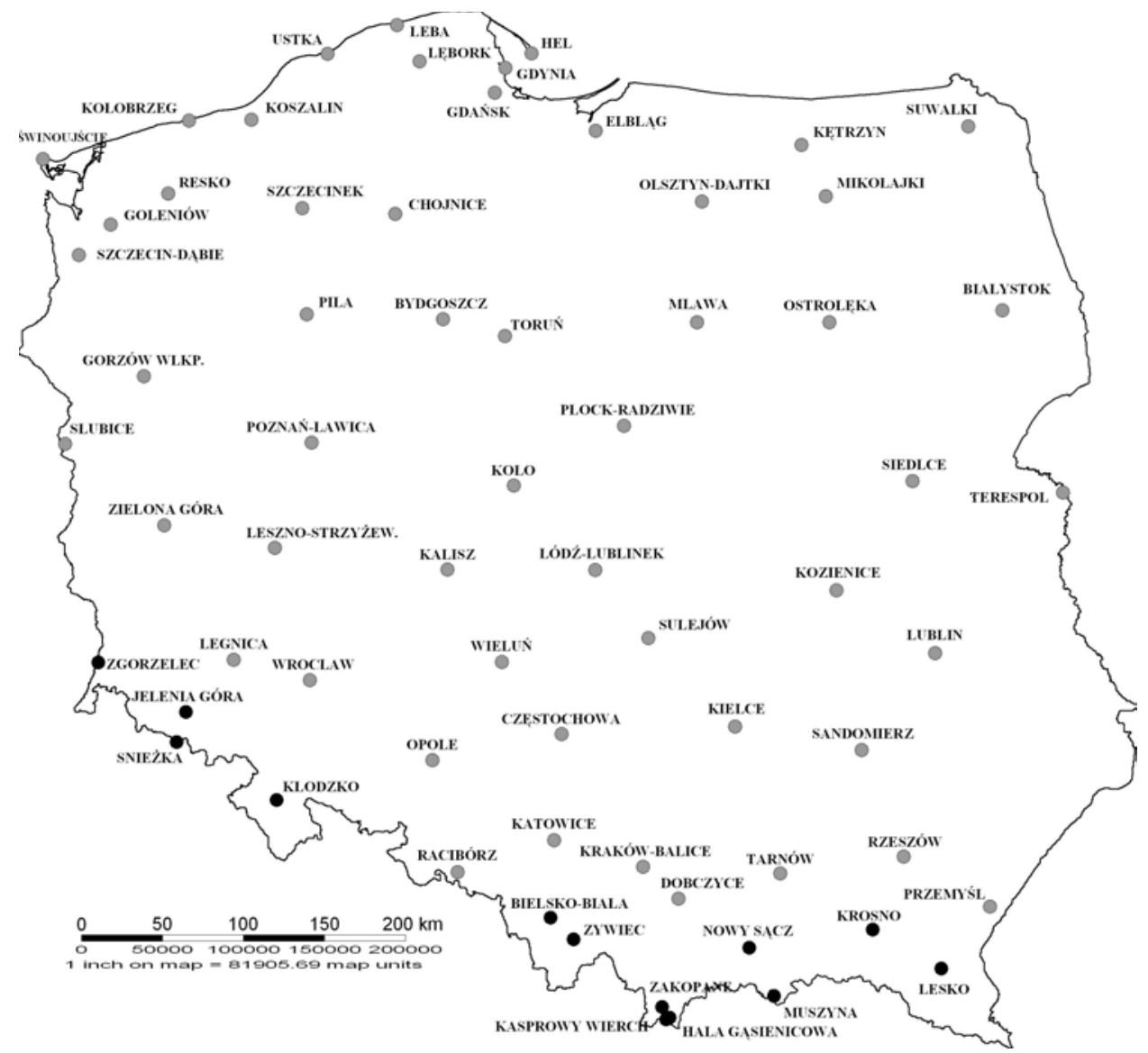

Rys. 3.2. Stacje meteorologiczne wykorzystane w opracowaniu. Stacje górskie i przedgórskie oznaczono czarnymi kropkami (wg Degirmendžića i Kożuchowskiego, 2015a) 
Pola opadów w Polsce związane z daną trajektorią MEC przedstawiono jako rozkłady przestrzenne sum dobowych uśrednione $\mathrm{z}$ terminów związanych z wszystkimi punktami opadotwórczego odcinka trajektorii - tzn. z terminów kiedy $M E C$ znalazły się w granicach okręgów o środkach w punktach wyznaczających odcinek opadotwórczy trajektorii.

\section{Geneza śródziemnomorska opadu w Polsce}

Zastosowano dwie metody określania genezy śródziemnomorskiej opadów w Polsce (MCP - Mediterranean Cyclonal Precipitation). Według pierwszej za „opad śródziemnomorski” uznano opad dobowy, który wystąpił na danej stacji w Polsce w dniu, kiedy centrum cyklonu śródziemnomorskiego znajdowało się najbliżej tej stacji w porównaniu z pozycją innych układów cyklonalnych, rozwijających się tego dnia na półkuli północnej. Obliczono wartość ortodromy łączącej stację notującą opad z centrum każdego cyklonu. Jeśli najmniejsza wartość ortodromy dotyczyła $M E C$ - opad na danej stacji zaklasyfikowano do klasy „opadów śródziemnomorskich”. W ten sposób wyznaczone wartości $M C P$ wykorzystano do oszacowania sum miesięcznych, sezonowych i rocznych opadu. Obliczono udziały $M C P$ w całkowitej sumie opadów w Polsce. Określono także zmiany sezonowe oraz trendy opadów o genezie śródziemnomorskiej w Polsce (zob. rozdz. 5 i 8).

Druga metoda oparta jest na założeniu, że opad $M C P$ występuje w dniach kiedy niże $M E C$ usytuowane są na opadotwórczych odcinkach trajektorii. W ten sposób zdefiniowane $M C P$ wykorzystano w analizie badającej wpływ toru $M E C$ na pole opadów w Polsce (zob. rozdz. 6).

\section{Charakterystyki opadów}

Wyznaczono wskaźniki efektywności opadów MCP zdefiniowane jako ilorazy średniej dobowej sumy $M C P$ i średniej obfitości opadów całkowitych w danym miejscu. Wskaźniki efektywności opadów MCP (Ie, wyrażone w \%) informują, jak wysokie są opady o genezie śródziemnomorskiej w relacji do średniej wysokości całkowitych sum opadów w dniach z opadem. Efektywność opadów śródziemnomorskich oznacza zatem ich znaczenie dla kształtowania całkowitych sum opadowych; wskaźnik Ief $>1$ (czyli Ie >100\%) ozna- 
cza, że opad MCP charakteryzuje się ponadprzeciętną obfitością i wpływa na wzrost całkowitej sumy opadów.

Obliczono ponadto ilorazy wysokości dobowych opadów MCP (DP - Daily Precipitation) i odpowiadającej im zawartości wilgoci PW. Ilorazy DP/PW stanowią odpowiednik współczynnika efektywności układu opadotwórczego, który na przykładzie opadów w Kieleckiem badał Suligowski $(2004,2013)$.

\section{Baza danych wilgotnościowych, termicznych oraz cyrkulacyjnych}

Sprawdzono w jaki sposób MEC modyfikują warunki termiczne i wilgotnościowe w dolnej troposferze nad Europą. Scharakteryzowano również pole geopotencjału $500 \mathrm{hPa}$ oraz pole wiatru i dywergencji w górnej troposferze związane z wystąpieniem $M E C$ na trasach przechodzących przez Europę Środkowo-Wschodnią. Wykorzystano do tej analizy poniższe serie danych:

- zawartość wilgoci w atmosferze [mm] $(P W)$ oraz wilgotność właściwą na powierzchni $1000 \mathrm{hPa}\left[\mathrm{g} \mathrm{kg}^{-1}\right.$;

- temperaturę powietrza na wys. $2 \mathrm{~m}$ npt. $\left[{ }^{\circ} \mathrm{C}\right]$;

- składowe wiatru na powierzchni 1000 i $300 \mathrm{hPa}\left[\mathrm{m} \mathrm{s}^{-1}\right.$;

- geopotencjał powierzchni 500 i $300 \mathrm{hPa}$ [m].

Serie pochodzą z bazy NCEP-NCAR Reanalysis (Kalnay i in., 1996) i udostępnione są na stronie Climate Research Unit, University of East Anglia (Harris, dostęp on-line: listopad 2014). Dane charakteryzują się rozdzielczością czasową 6-godzinną oraz przestrzenną $2,5^{\circ} \times 2,5^{\circ}$. Obejmują okres 1958-2008. W pracy przedstawiono średnie pola wybranych parametrów w sektorze $70^{\circ} \mathrm{W}-70^{\circ} \mathrm{E}$ oraz $20^{\circ}-80^{\circ} \mathrm{N}$. Na podstawie pola wiatru i wilgotności właściwej na powierzchni $1000 \mathrm{hPa}$ policzono strumienie wilgoci zgodnie z wzorem (Malik i Taylor, 2011):

$$
Q=q V
$$

gdzie: $Q$ - strumień wilgoci $\left[\mathrm{g} \cdot \mathrm{kg}^{-1} \cdot \mathrm{m} \cdot \mathrm{s}^{-1}\right], q$ - wilgotność właściwa $\left[\mathrm{g} \cdot \mathrm{kg}^{-1}\right]$, $V$ - wektor wiatru $\left[\mathrm{m} \cdot \mathrm{s}^{-1}\right]$, a także konwergencję strumienia wilgoci (MFC) według formuły (Banacos i Schultz, 2005):

$$
M F C=-U \frac{\partial q}{\partial x}-V \frac{\partial q}{\partial y}-q\left(\frac{\partial U}{\partial x}+\frac{\partial V}{\partial y}\right)
$$

gdzie: $U$ i $V$ to składowa równoleżnikowa i południkowa wiatru, $q$ to wilgotność właściwa, $x$ oraz y stanowią odcinki równoleżnika i południka. 
Obliczono również średnie wartości PW na obszarze Polski na podstawie sześciu punktów gridowych o współrzędnych $15^{\circ} \mathrm{E}, 17,5^{\circ} \mathrm{E}, 20^{\circ} \mathrm{E}$ i $22,5^{\circ} \mathrm{E}$ na równoleżniku $52,5^{\circ} \mathrm{N}$ oraz $20^{\circ} \mathrm{E}$ i $22,5^{\circ} \mathrm{E}$ na szerokości geograficznej $50^{\circ} \mathrm{N}$. Wyznaczono średnie dobowe wartości PW dla każdego dnia w roku, a następnie obliczono względne odchylenia PW od średniej wieloletniej wartości PW w dniach występowania $M C P(\Delta)$. Odchylenia $\Delta$ pozwalają na ocenę zmian zawartości wilgoci w atmosferze niezależnie od rocznego cyklu PW.

Dywergencję ( $\delta$ ) obliczono $\mathrm{z}$ wzoru definiującego ten parametr w układzie odniesienia związanym z powierzchnią sfery, w którym oś $x$ skierowana jest na wschód, a oś y na północ (Bluestein, 1992, s. 114):

$$
\delta=\frac{\partial u}{\partial x}+\frac{\partial v}{\partial y}-\frac{v}{a} \tan \varphi
$$

Pierwszy człon prawej strony równania stanowi pochodną składowej strefowej wiatru $(u)$ po odcinku równoleżnika $(x)$, drugi człon wzoru jest pochodną składowej południkowej $(v)$ po odcinku południka $(y)$, trzeci człon jest tzw. poprawką na zbieżność południków, w tym $a$ jest promieniem Ziemi, a $\varphi$ stanowi szerokość geograficzną punktu, w którym szacowana jest dywergencja. Obliczona powyższą metodą dywergencja jest czuła na błędy pomiarowe wiatru, nie znajduje więc zastosowania $\mathrm{w}$ procedurach prognostycznych, natomiast średnie wartości tego parametru, uśrednione w okresie czasu nad danym obszarem, mogą stanowić wiarygodną ocenę warunków meteorologicznych lub klimatologicznych (Gordon i in., 1998, s.115; Nakamura, 1993; Sechrist i Whittaker, 1979). Znak średniej dywergencji informuje o tym, czy nad danym obszarem występują warunki sprzyjające czy też hamujące aktywność cyklonalną.

Dywergencję związaną z jet streak obliczono z dywergentnych składowych wiatru ageostroficznego normalnych względem wektorów wiatru geostroficznego. Dywergentne składowe wiatru ageostroficznego oszacowano na podstawie wzorów:

$$
u_{a g-d}=\frac{\partial \phi}{\partial x} \quad v_{a g-d}=\frac{\partial \phi}{\partial y}
$$

gdzie $\phi$ stanowi potencjał prędkości. Wartości $\phi$ w gridach wewnętrznych badanego obszaru uzyskano, stosując metodę nadrelaksacji sekwencyjnej. Szczegóły metody opisano m. in. w pracy Loughe'a i in. (1994). 


\section{Trendy MEC, makrotypów cyrkulacji V-G, opadów oraz zawartości wilgoci w atmosferze}

Wieloletnie zmiany niżów MEC w okresie 1958-2008 opisano na podstawie ich rocznej i sezonowej częstości oraz średnich rocznych i sezonowych wartości maksymalnej wirowości (laplasjanu ciśnienia), największej spadkowej tendencji ciśnienia oraz minimalnego ciśnienia w centrum każdego MEC. Maksymalną wirowość, maksymalną ujemną tendencję ciśnienia oraz minimalne ciśnienie wybrano spośród terminowych pomiarów (co 6 godz.) składających się na cykl życiowy niżu. W ten sposób, poza frekwencją niżów, otrzymano charakterystyki aktywności niżów i określono ich zmiany w wieloleciu. Określono także tendencje wieloletnie opadów $M C P$, opadów całkowitych, zawartości wilgoci w atmosferze nad Polską. Istotność współczynników trendu zweryfikowano testem Mann-Kendalla.

Określono wpływ czynników cyrkulacyjnych w skali makro na częstość występowania $M E C$. Wykorzystano do tego zadania informacje o makrotypach cyrkulacji Vangengeima-Girsa (V-G) zawarte w katalogu Dimitrieeva i Belyazo (2006) wraz z jego uaktualnieniem.

\section{Czynniki wpływające na opady MCP w Polsce}

Analizując związki korelacyjne między zawartością wilgoci w atmosferze, polem temperatury w Europie a opadami o genezie śródziemnomorskiej w Polsce, zastosowano m.in. współczynnik korelacji cząstkowej. Współczynnik ten wyraża się wzorem (Panofsky i Brier, 1958):

$$
r_{23.1}=\frac{r_{23}-r_{12} r_{13}}{\sqrt{1-r_{12}^{2}} \sqrt{1-r_{13}^{2}}}
$$

gdzie: $r_{23.1}$ - korelacja zmiennej 2 i 3 z wyeliminowanym wpływem zmiennej 1 , $r_{\mathrm{xy}}$ - korelacja prosta między zmienną x oraz y.

\section{Trajektorie wsteczne mas powietrza}

Wykorzystano Hysplit Trajectory Model, dostępny on-line na stronie NOAA Air Resources Laboratory, do konstrukcji trajektorii mas powietrza. Wykreślono trajektorie wsteczne 96-godzinne w dniach 3-10 lipca $1997 \mathrm{r}$. 
(„powódź tysiąclecia”). Docelowe punkty trajektorii stanowią macierz o rozdzielczości $2^{\circ} \times 2^{\circ}$ szerokości oraz długości geograficznej ograniczonej przez równoleżniki $49^{\circ}, 55^{\circ} \mathrm{N}$ oraz południki $14^{\circ}, 24^{\circ} \mathrm{E}$. Punkty docelowe znajdują się na wysokości $500 \mathrm{~m}$ npt. Obliczenia modelu Hysplit oparto na bazie NCEP-NCAR Reanalysis. 


\section{Rozdział 4 \\ Trajektorie ruchu i frekwencja niżów środziemnomorskich nad Europą Środkowo-Wschodnią}

\section{Szlak niżowy Vb}

Trajektorie ruchu cyklonów przemieszczających się nad Europą są przedmiotem badań klimatologicznych od czasu ukazania się prac W. Köppena (1882) i van Bebbera (1891). Klasyczny przykład rozmieszczenia charakterystycznych trajektorii cyklonów europejskich stanowi mapa van Bebbera, na której zobrazowano położenie pięciu grup szlaków niżowych (Zugstrassen der Minima). Wśród nich wyróżnia się szlak Vb, inaczej niż pozostałe, biegnący południkowo znad Adriatyku przez Europę Środkowo-Wschodnią aż do granic Finlandii. Liczba wędrujących tym szlakiem cyklonów nie jest mała; Hann (1906) podawał, że w latach 1876-1889 stanowiły one około 15\% wszystkich cyklonów występujących nad Europą. Nieco więcej (18\%) pojawiało się ich wtedy w półroczu ciepłym, mniej w półroczu chłodnym (13\%).

Szlaki wędrówek niżów śródziemnomorskich, mimo długoletnich badań, nie są nadal usystematyzowane. Już Defant (1926, s. 127) zauważył „brak porządku" (ziemlich konfusen Bilde) w obrazie trajektorii niżów. Kendrew (1930) w swej książce zamieścił różne ujęcia szlaków wędrówek cyklonów nad Europą (s. 254-255), przy czym wśród ich wielkiej liczby... nie ma szlaku, przypominającego dyskutowany tu tor $\mathrm{Vb}$ !

Prezentowane w późniejszych pracach szlaki niżów nawiązują w większości do trasy Vb van Bebbera: analogiczne lub podobne do niej są na przykład szlak 3a według Ujvari (za: Apostol, 2008), szlak I według Sorodoc (za: Apostol, 2008), szlak II według Pribisch i Bordeianu (za: Apostol, 2008) i szlak III według Grimami i Beseaga (za: Apostol, 2008), a także trasa T7 ustalona przez Bielec-Bąkowską (2010). HMSO (1962) wykazuje istnienie trasy 3a, 
wzdłuż której wędrują cyklony w kierunku wschodniej Europy. Maheras (1983) określił występowanie szlaku SW1, podobnego do Vb, ale dzielącego się nad kontynentem na dwa odcinki, z których jeden przechodzi przez południowo-wschodnią część Polski, a drugi - omija Polskę od wschodu.

\section{Sezonowość frekwencji niżów MEC}

Działalność cyklonalna nad Morzem Śródziemnym rozwija się w chłodnej połowie roku w związku z oddziaływaniem śródziemnomorskiej gałęzi frontu polarnego (Martyn, 2000). W basenie śródziemnomorskim ma miejsce intensywna cyklogeneza, dzięki której przeważająca część układów cyklonalnych występujących na tym obszarze ma autochtoniczny charakter: spośród średniej rocznej liczby 76 cyklonów tam występujących, aż 69 powstaje nad Morzem Śródziemnym, z czego kolejna większość (52 niże) tworzy się nad Zatoką Genueńską („niże genueńskie”). Jednakże sezonowe zróżnicowanie częstości niżów śródziemnomorskich tylko częściowo potwierdza ich związek z chłodną połową roku: $33 \%$ cyklonów notuje się na wiosnę, $28 \% \mathrm{w}$ zimie, $22 \%$ jesienią i $17 \%$ latem. Podobne wartości sezonowe dotyczą niżów genueńskich: wiosna - 27\%, zima - 30\%, jesień - $24 \%$ i lato - 19\%. (H.M.S.O., 1962). Cyklony śródziemnomorskie tworzą się więc także w ciepłej porze roku.

Hann (1906) pisał, że częstość niżów pojawiających się na szlaku Vb osiąga maksima na wiosnę i w październiku i że od lipca do września klin wyżowy znad zachodniej Europy blokuje ruch tych niżów ku północy. Van Bebber (1891) wyznaczył jedną trasę Vb dla cyklonów zimowych oraz trzy szlaki, na których cyklony śródziemnomorskie pojawiają się latem.

Mapy szlaków niżowych Alperta i in. (1990) pozwalają sądzić, iż niże znad basenu śródziemnomorskiego mogą przemieszczać się w kierunku północno-wschodnim zarówno w zimie, zwłaszcza w lutym, jak i w czerwcu, lipcu i sierpniu.

Wobec nie w pełni jednoznacznych ocen sezonowych wahań występowania niżów na szlaku $\mathrm{Vb}$, dla zrozumienia zmian ich frekwencji w ciągu roku ważna staje się teza wskazująca, że niże śródziemnomorskie przemieszczają się w kierunku Europy Środkowo-Wschodniej podczas kształtowania się południkowych form cyrkulacji w środkowej i górnej troposferze. „Układy powstające nad północną częścią Włoch wędrują niemal wzdłuż osi prądu strumieniowego, przecinają Nizinę Węgierską i docierają do Karpat Wschodnich" (Bartoszek, 2006). Inaczej mówiąc, niże mogą wędrować szlakiem Vb i docie- 
rać do Europy Środkowo-Wschodniej w tych porach roku, w których cyrkulacja strefowa słabnie. Sezonami takimi są przejściowe pory roku, zwłaszcza wiosna (Wibig, 1999a, 1999b).

\section{Cele i materiał analizy}

Weryfikacja hipotezy o zwiększającej się na wiosnę i w jesieni frekwencji niżów śródziemnomorskich, przemieszczających się w głąb kontynentu i wpływających na warunki atmosferyczne w Polsce i krajach sąsiednich oraz ocena liczby oraz trajektorii ruchu tych układów, są przedmiotem niniejszego rozdziału.

Materiałem opracowania jest 351 niżów śródziemnomorskich (MEC), które pogrupowano według kryteriów, uwzględniających umiejscowienie punktu cyklolizy oraz przebieg trajektorii. W klasyfikacji niżów posłużono się schematem siatki 4 równoleżników i 4 południków, przedstawionych na rys. 3.1 i pozwalającym na wydzielenie sektorów: centralnego (C), obejmujący obszar Polski, wschodniego (E), zachodniego (W), północnego (N) i południowego (S). Niże, według tego schematu, przypisano odpowiednio do klasy (typu) C, E, W lub S.

\section{Typy trajektorii ruchu niżów MEC}

W wyniku zastosowania przyjętej procedury klasyfikacji wyróżniono 12 typów trajektorii, wzdłuż których niże przemieszczają się znad Morza Śródziemnego, Czarnego lub Azowskiego nad środkową lub wschodnią Europę.

Centralne typy trajektorii cyklonów (C) przebiegają z południa na północ przez sektor centralny, przy czym w typie C1 okluzja i dyssypacja tych układów następują na terytorium Europy Środkowo-Wschodniej, a w typie C2 - poza nim. Zachodnie typy trajektorii cyklonów (W) przebiegają przez sektor zachodni. W typie W1 niże ulegają cyklolizie w pobliżu terytorium Polski, w typie W2 - w pewnym oddaleniu (patrz: rozdz. 3 - Kryteria klasyfikacji). Analogicznie, typy wschodnie (E) mają tory przebiegające przez sektor wschodni, miejsce cyklolizy w sąsiedztwie obszaru Polski (typ E1) lub poza terytorium Europy Środkowo-Wschodniej (typ E2). Typy E reprezentują trajektorie, najbardziej odpowiadające szlakowi niżów Vb van Bebbera. Południowe typy trajektorii (S) leżą w sektorze południowym; do typu S1 należą te szlaki 
niżowe, które kończy dyssypacja układów w sektorze południowym, do typu S2 należą tory wybiegające poza przyjętą granicę Europy Środkowo-Wschodniej, tj. poza południk $30^{\circ} 44^{\prime} \mathrm{E}$.

Wydzielono ponadto trajektorie niżów czarnomorskich (BS): BSS (miejsca cyklolizy na południe od Polski), BSN (miejsca cyklolizy na północ od Polski), BSE (trajektorie zbliżające się od wschodu do terytorium Polski), BSC (trajektorie wchodzące do sektora centralnego).

Niże pochodzące znad basenu Morza Śródziemnego przemieszczają się nad Europą po różnych torach, z których najczęściej wykorzystywany jest szlak typu C - przechodzący centralnie przez Polskę. Dość wysoką frekwencją charakteryzuje się też szlak biegnący na wschód od Polski (typ E), który w przybliżeniu odpowiada torowi $\mathrm{Vb}$, wskazanemu przez van Bebbera.

\section{Częstość niżów MEC na trajektoriach}

Średnio w roku nad Europą Środkowo-Wschodnią pojawia się około 7 cyklonów śródziemnomorskich. Ponad 20\% niżów reprezentuje typ C1 - są to układy przemieszczające się przez Polskę i ulegające dyssypacji na obszarze Europy Środkowo-Wschodniej (rys. 4.1). Łącznie z typem C2 niże przechodzące przez Polskę stanowią 34,2\% ogólnej liczby niżów śródziemnomorskich. Drugie miejsce w rankingu frekwencji zajmuje typ S1 - niże wędrujące przez sektor południowy (rys. 4.2). Niże należące do typu południowego (S) stanowią 25,9\% wszystkich układów.

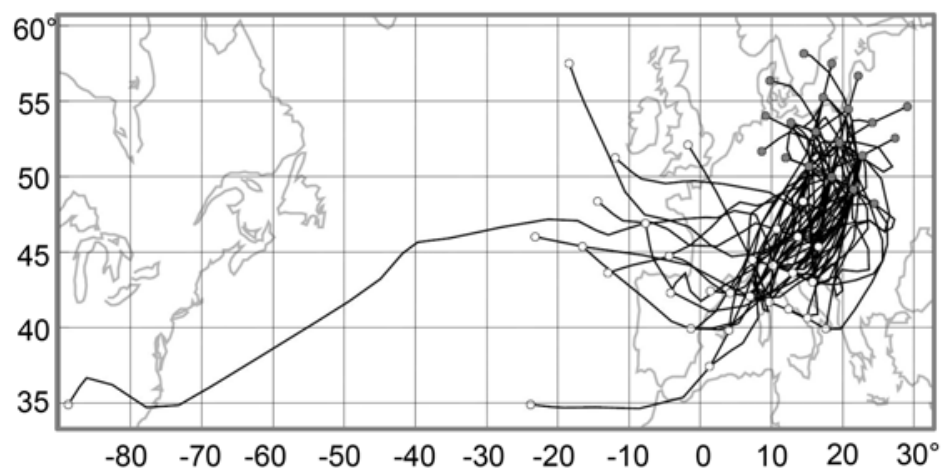

Rys. 4.1. Trajektorie niżów śródziemnomorskich typu C1. Zaznaczono miejsca cyklogenezy (puste koła) i cyklolizy (szare koła) (wg Degirmendžića i Kożuchowskiego, 2014) 


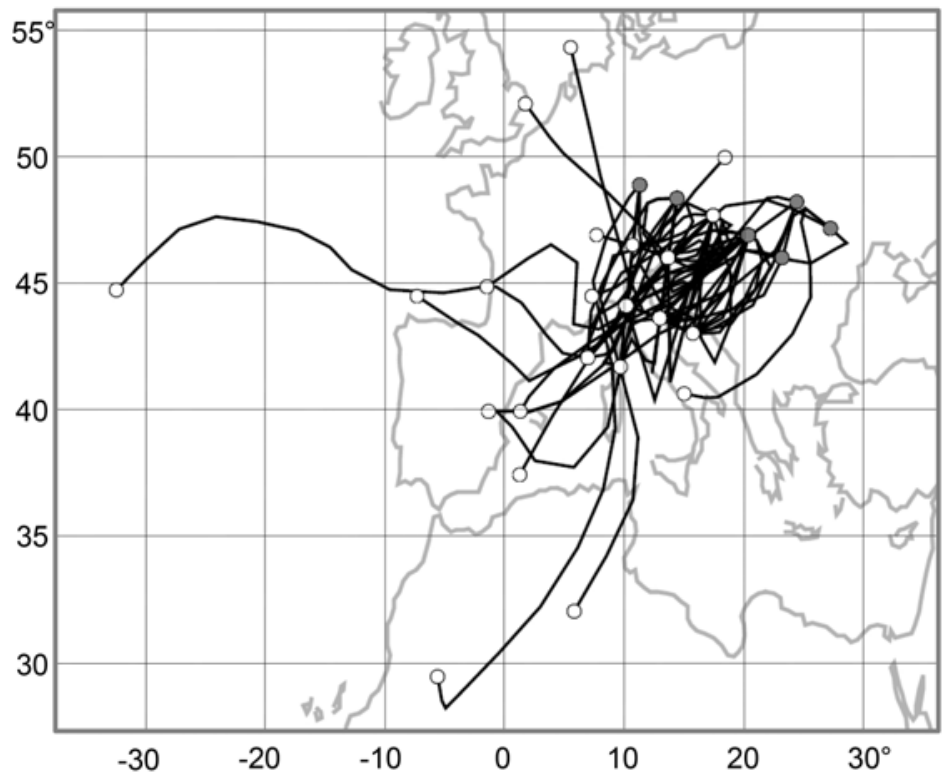

Rys. 4.2. Trajektorie niżów śródziemnomorskich typu S1. Oznaczenia jak na rys. 4.1 (wg Degirmendžića i Kożuchowskiego, 2014)

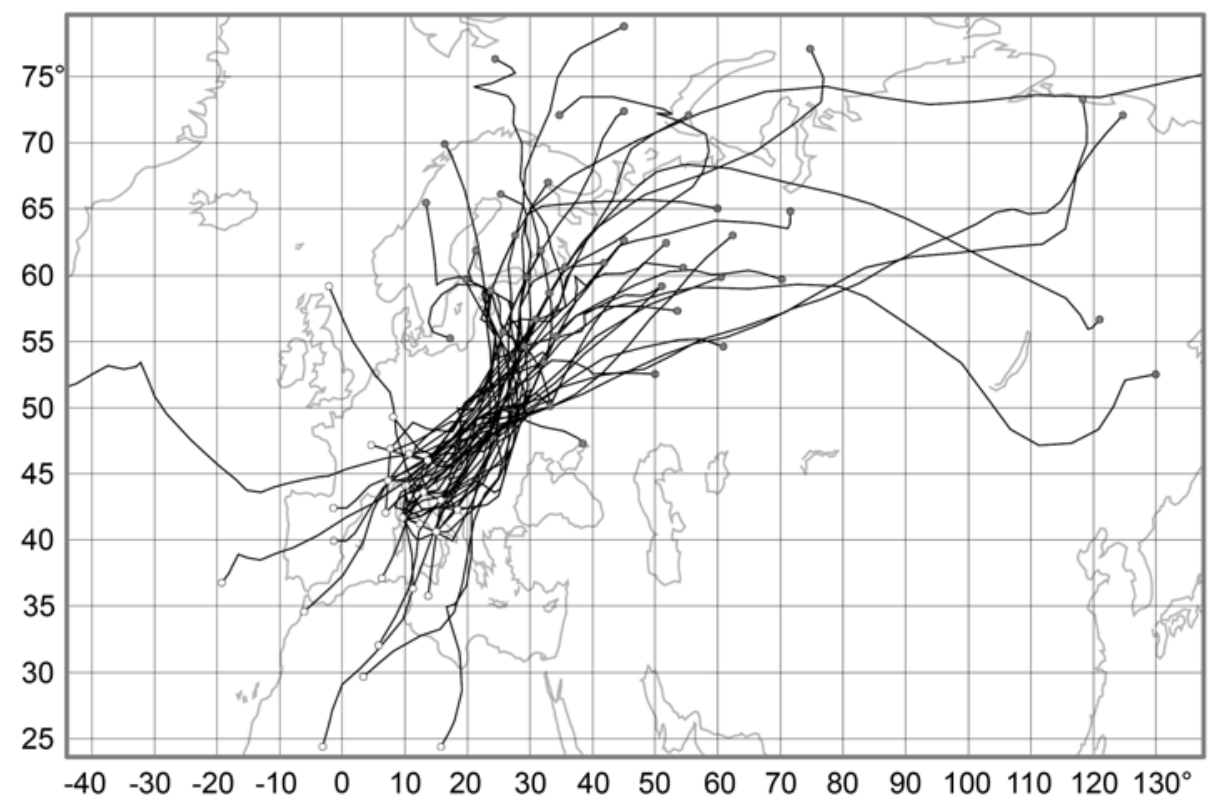

Rys. 4.3. Trajektorie niżów śródziemnomorskich typu E2. Oznaczenia jak na rys. 4.1 (wg Degirmendžića i Kożuchowskiego, 2014) 
Na trzecim miejscu pod względem frekwencji znajdują się niże przemieszczające się w sektorze wschodnim i ulegające dyssypacji poza terenem Europy Środkowo-Wschodniej; jest to typ E2 (rys. 4.3). Typy wschodnie (E) stanowią łącznie 22,8\% przypadków, niże czarnomorskie (BS) - 9,4\%, a niże należące do typu W - 7,7\% (tab. 4.1).

Tab. 4.1. Liczba niżów śródziemnomorskich w Europie Środkowo-Wschodniej w latach 1958-2008 (wg Degirmendžića i Kożuchowskiego, 2014)

\begin{tabular}{lrrrr}
\hline Typy & $\mathbf{n}_{\text {typ }}$ & $\mathbf{n}$ & $\%$ & $\mathbf{w / c}$ \\
\hline C1 & 72 & 1,4 & 20,5 & 1,0 \\
C2 & 48 & 0,9 & 13,7 & 1,4 \\
C & 120 & 2,4 & 34,2 & 1,1 \\
W1 & 13 & 0,3 & 3,7 & 1,6 \\
W2 & 14 & 0,3 & 4,0 & 2,5 \\
W & 27 & 0,5 & 7,7 & 2,0 \\
E1 & 29 & 0,6 & 8,3 & 0,6 \\
E2 & 51 & 1,0 & 14,5 & 1,1 \\
E & 80 & 1,6 & 22,8 & 0,9 \\
S1 & 63 & 1,2 & 17,9 & 1,2 \\
S2 & 28 & 0,5 & 8,0 & 1,0 \\
S & 91 & 1,8 & 25,9 & 1,1 \\
BSS & 10 & 0,2 & 2,8 & 9,0 \\
BSN & 11 & 0,2 & 3,1 & 1,7 \\
BSE & 8 & 0,2 & 2,3 & 1,0 \\
BSC & 4 & 0,1 & 1,1 & 1,0 \\
BS & 33 & 0,6 & 9,4 & 2,0 \\
IMEC & $\mathbf{3 5 1}$ & $\mathbf{6 , 9}$ & $\mathbf{1 0 0}$ & $\mathbf{1 , 2}$
\end{tabular}

$\mathrm{n}_{\text {typ }}$ - liczba MEC z podziałem na typy ich trajektorii,

$\mathrm{n}$ - średnia liczba roczna,

$\%$ - udział poszczególnych typów w całkowitej liczbie nizów,

w/c - stosunek liczby niżów w półroczu ciepłym (IV-IX) do liczby niżów w pótroczu chłodnym (X-III).

W półroczu ciepłym częstość niżów jest nieco większa od częstości w półroczu chłodnym - 54\% niżów odnotowano w okresie od kwietnia do września, $46 \%$ - w pozostałej części roku. Przewaga liczby niżów w ciepłym półroczu dotyczy większości wyróżnionych typów trajektorii; ilorazy częstości niżów w półroczu ciepłym i półroczu chłodnym są na ogół wyższe od 1 (tab. 4.1). 


\section{Zmiany sezonowe frekwencji niżów}

Wykazano sezonową zmienność częstości pojawiania się niżów śródziemnomorskich w Europie Środkowo-Wschodniej; zmienność ta charakteryzuje się półroczną cyklicznością z maksimami w kwietniu i październiku. Maksimum wiosenne jest najbardziej rozwinięte i wiąże się najprawdopodobniej $\mathrm{z}$ dominującymi w tej porze roku południkowymi formami cyrkulacji nad Europą, które sprzyjają wędrówce niżów znad Morza Śródziemnego na północ.

Niże śródziemnomorskie stosunkowo rzadko zdarzają się w lipcu, chociaż wtedy ryzyko związanych z nimi skrajnie wysokich opadów atmosferycznych w środkowej Europie jest szczególnie duże.

Największa miesięczna częstość niżów śródziemnomorskich występuje w kwietniu, najmniej jest ich w styczniu i w lipcu (tab. 4.2). Po lipcowym minimum częstości niżów przejściowo podnoszą się, tworząc drugorzędne maksimum jesienne. Wiosenne maksimum pojawia się w przebiegu rocznym częstości niżów, reprezentujących wszystkie typy trajektorii i przypada na kwiecień lub maj. Majowe maksimum niżów „zachodnich” (typ W) jest najwyraźniejsze; na ten miesiąc przypada prawie $1 / 4$ wszystkich niżów „W”. Jesienny wzrost częstości niżów śródziemnomorskich jest słabiej zaznaczony; osiąga on maksima w różnych miesiącach jesieni, w przypadku niżów czarnomorskich - jest to maksimum jesienno-zimowe (tab. 4.2). Najsilniej rozwiniętą sezonowość, określoną na podstawie współczynnika nierównomierności miesięcznych liczb notowanych niżów (tzw. współczynnik sezonowości), reprezentują niże typu „W”, znaczną nierównomiernością charakteryzują się tez niże południowe (S) i czarnomorskie (BS). Stosunkowo małą nierównomierność rocznego rozkładu wykazują niże należące do typu centralnego (C). Wszystkie układy ( $\Sigma M E C)$ charakteryzuje współczynnik nierównomierności $\mathrm{V}_{\mathrm{n}}=0,25$ (tab. 4.2). Przedstawione tu oceny wskazują wyraźnie, że sezonowość niżów śródziemnomorskich stanowi znaczącą cechę ich występowania w Europie ŚrodkowoWschodniej.

Analiza harmoniczna miesięcznych częstości niżów wskazuje, że w ich rocznym przebiegu dominuje cykliczność półroczna, odzwierciedlająca wiosenne i jesienne maksima MEC. Półroczna harmonika ma maksima przypadające na kwiecień i październik, minima - na styczeń i lipiec, przy czym maksima są dwukrotnie wyższe od minimów (rys. 4.4). 
Tab. 4.2. Udział miesięcznej liczby niżów śródziemnomorskich w ich liczbie rocznej

(\%) oraz współczynniki nierównomierności miesięcznych częstości niżów ( $\left.\mathrm{V}_{\mathrm{n}}\right)$ (wg Degirmendžića i Kożuchowskiego, 2014)

\begin{tabular}{lrrrrrrrrrrrrr}
\hline Typy niżów & I & II & III & IV & $\mathbf{V}$ & VI & VII & VIII & IX & X & XI & XII & Vn \\
\hline C & 4,1 & 8,6 & 7,4 & $\mathbf{1 5 , 7}$ & 13,9 & 6,5 & 3,6 & 10,6 & 3,3 & 11,6 & 7,5 & 7,6 & 0,37 \\
W & 0,0 & 7,4 & 3,7 & 12,1 & $\mathbf{2 4 , 9}$ & 1,9 & 1,9 & 7,4 & 18,5 & 7,4 & 11,1 & 3,7 & 0,67 \\
E & 5,3 & 9,5 & 11,6 & $\mathbf{1 4 , 2}$ & 7,2 & 6,2 & 2,5 & 3,9 & 13,6 & 9,9 & 7,5 & 8,5 & 0,35 \\
S & 1,1 & 9,7 & 12,3 & $\mathbf{1 5 , 1}$ & 10,7 & 4,9 & 4,3 & 12,2 & 5,4 & 4,4 & 14,3 & 5,5 & 0,49 \\
BS & 9,1 & 9,1 & 3,0 & $\mathbf{1 8 , 2}$ & 3,5 & 17,7 & 12,1 & 8,8 & 6,4 & 0,0 & 3,0 & 9,1 & 0,51 \\
I MEC & 3,7 & 9,1 & 8,9 & $\mathbf{1 5 , 1}$ & 11,4 & 6,7 & 4,2 & 9,1 & 7,7 & 7,9 & 9,1 & 7,1 & 0,25 \\
\hline
\end{tabular}

pogrubiona czcionka oznacza najwyższe wartości miesięczne

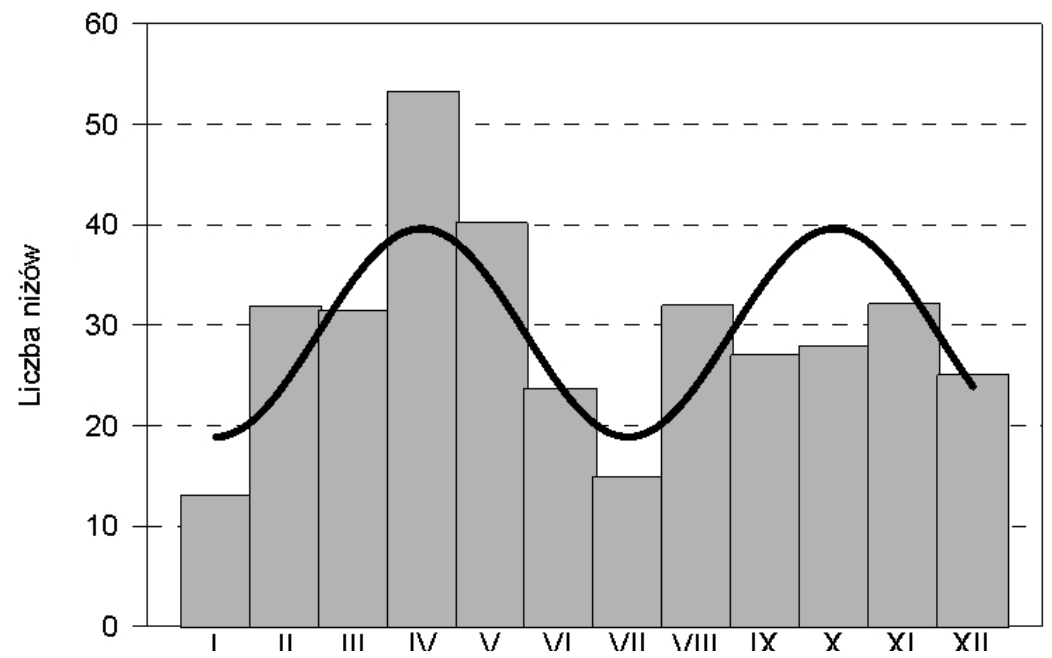

Rys. 4.4. Miesięczne liczby niżów śródziemnomorskich w Europie Środkowo-Wschodniej w okresie 1958-2008 oraz ich półroczna składowa harmoniczna (wg Degirmendžića i Kożuchowskiego, 2014)

Harmonika półroczna jest istotnie skorelowana z częstościami empirycznymi; współczynnik korelacji wynosi 0,72 i jest istotny na poziomie 0,01 (tab. 4.3). Najwyraźniejszy cykl półroczny reprezentują niże wschodnie (typu E). Słabszą cykliczność półroczną można przypisać niżom typu S, a zwłaszcza BS; te ostatnie mają za to wyraźniejszą cykliczność roczną. Cykl roczny nie jest jednak znaczący; współczynniki korelacji harmoniki rocznej i częstości empirycznych nie osiągają poziomu istotności 0,05 . 
Tab. 4.3. Współczynniki korelacji miesięcznych częstości niżów śródziemnomorskich i harmoniki półrocznej (r6) oraz rocznej (r12) (wg Degirmendžića i Kożuchowskiego, 2014)

\begin{tabular}{lrr}
\hline Typy niżów & $\mathbf{r 6}$ & $\mathbf{r 1 2}$ \\
\hline C & $\mathbf{0 , 6 1}$ & 0,36 \\
W & $\mathbf{0 , 6 1}$ & 0,25 \\
E & $\mathbf{0 , 8 0}$ & 0,33 \\
S & 0,52 & 0,32 \\
BS & 0,39 & 0,51 \\
$\Sigma$ MEC & 0,72 & 0,41 \\
\hline
\end{tabular}

Pogrubioną czcionkq wyróżniono współczynniki istotne na poziomie $\alpha=0,05$ (wg symulacji Monte Carlo - patrz: rozdz. 3)

Trzeba podkreślić, że wykryte prawidłowości występowania niżów śródziemnomorskich w Europie Środkowo-Wschodniej są opisem zdarzeń rzadkich. Empiryczne prawdopodobieństwo pojawienia się niżu śródziemnomorskiego na badanym obszarze jest niewielkie. W skali rocznej dzień z MEC zdarza się z prawdopodobieństwem nie sięgającym $2 \%$. W porze wiosennego maksimum frekwencji niżów prawdopodobieństwo to wzrasta do zaledwie 2-3\%, a w odniesieniu do najczęściej występujących niżów typu C - wynosi około $1 \%$ (tab. 4.4).

Tab. 4.4. Prawdopodobieństwo empiryczne dnia z niżem śródziemnomorskim $M E C$ (w \%) i z niżem typu centralnego (C) w poszczególnych miesiącach oraz w ciągu roku (I-XII) (wg Degirmendžića i Kożuchowskiego, 2014)

\begin{tabular}{lrrrrrrrrrrrrr}
\hline Typ niżu & I & II & III & IV & V & VI & VII & VIII & IX & X & XI & XII & I-XII \\
\hline MEC & 0,8 & 2,2 & 2,0 & 3,4 & 2,5 & 1,5 & 0,9 & 2,0 & 1,9 & 1,8 & 2,1 & 1,6 & 1,9 \\
C & 0,3 & 0,7 & 0,6 & 1,2 & 1,1 & 0,5 & 0,3 & 0,8 & 0,3 & 0,9 & 0,6 & 0,6 & 0,6 \\
\hline
\end{tabular}

Warto jednak zauważyć, że to właśnie sporadyczne i w znacznym stopniu losowe zjawisko przemieszczania się niżów śródziemnomorskich nad centralną częścią kontynentu staje się zjawiskiem ekstremalnym, w szczególności ze względu na ryzyko powodowania przez nie skrajnie wysokich opadów w Europie. 


\section{Wnioski}

Niże pochodzące znad basenu Morza Śródziemnego przemieszczają się nad Europą po różnych torach, z których najczęściej wykorzystywany jest szlak typu C - przechodzący centralnie przez Polskę. Dość wysoką frekwencją charakteryzuje się też szlak biegnący na wschód od Polski (typ E), który w przybliżeniu odpowiada torowi Vb, wskazanemu przez van Bebbera.

Częstość występowania niżów śródziemnomorskich nad Europą Środkowo-Wschodnią jest stosunkowo niewielka: rocznie notuje się przeciętnie 7 takich przypadków, a prawdopodobieństwo wystąpienia w danym dniu roku niżu śródziemnomorskiego nie sięga $2 \%$.

Wykazano sezonową zmienność częstości pojawiania się niżów śródziemnomorskich w Europie Środkowo-Wschodniej; zmienność ta charakteryzuje się półroczną cyklicznością z maksimami w kwietniu i październiku. Maksimum wiosenne jest najbardziej rozwinięte i wiąże się najprawdopodobniej z dominującymi w tej porze roku południkowymi formami cyrkulacji nad Europą, które sprzyjają wędrówce niżów znad Morza Śródziemnego na północ.

Niże śródziemnomorskie stosunkowo rzadko zdarzają się w lipcu, chociaż wtedy ryzyko związanych z nimi skrajnie wysokich opadów atmosferycznych w środkowej Europie jest szczególnie duże.

Degirmendžić J., Kożuchowski K., 2014, Sezonowe wahania liczby niżów śródziemnomorskich w Europie Środkowo-Wschodniej. Przegląd Geofizyczny, t. LIX, z. 1-2, s. 5-18. 


\section{Rozdział 5 \\ Niże śródziemnomorskie i opady w Polsce}

\section{Opady o genezie śródziemnomorskiej w Polsce}

Cyklony śródziemnomorskie, w swym położeniu na południe i na wschód od Polski, tworzą układ cyrkulacji cyklonalnej wschodniej i północno-wschodniej Eo (wg klasyfikacji Osuchowskiej-Klein, 1978), przynoszący wysokie opady zarówno we wschodniej części polskiego Wybrzeża (Świątek, 2008), w Polsce Północno-Zachodniej (Kirschenstein, 2013), jak i w głębi kraju, m.in. w Łodzi (Wibig i Fortuniak, 1998) oraz w górach i na ich przedpolu, na przykład we Wrocławiu (Dubicka, 1991) i w Krakowie (Twardosz, 1997).

Absolutne maksima opadów dobowych w wielu miejscach na południu kraju związane są z działalnością niżów śródziemnomorskich: były to m.in. sumy dobowe z dnia 21.08.1972 r. w Bielsku Białej (147 mm), z dnia 20.07.2001 r. w Jeleniej Górze (119 mm) i z dnia 30.07.1977 r. na Śnieżce (150 mm). Co czwarty niż śródziemnomorski przynosi w Polsce opady dobowe $>50 \mathrm{~mm}$ (Bartoszek, 2006). Morozowska (1987) oraz Stachy i Bogdanowicz (1998, 2002) podają, że 88 \% silnych powodzi w Polsce związanych jest z działalnością niżów na szlaku Vb. Podobną ocenę stopnia zagrożenia powodziowego, związanego z wysokimi opadami pochodzenia śródziemnomorskiego przedstawili Buchert i in. (2013).

Przykładami działalności niżów śródziemnomorskich w ostatnich latach były m.in. nawalne opady i powodzie w Czechach i Polsce w 2010 r. oraz obfite opady śniegu w krajach Europy Środkowej i na Ukrainie w jesieni, zimą i na wiosnę w 2012/2013 roku.

W fazie wypełniania się niże śródziemnomorskie nad środkową Europą przyjmują quasi-stacjonarny charakter, a opady z nimi związane stają się długotrwałe. Ekstremalnie wysoki poziom osiągają w związku z tym 2-5 dniowe sumy opadów, niejednokrotnie przewyższające średnią miesięczną wysokość 
opadu. Na przykład na Śnieżce opad z dnia 30.07.1977 r. równy był średniej sumie miesięcznej w lipcu, a opad z dnia 1.08.1977 r. - był bliski sumie sierpniowej (Otop, 2003). Opad w Raciborzu, trwający w dniach 5-9.07.1977 r. stanowił 266\% średniej sumy opadów w lipcu, opady w Małopolsce w maju 2010 r. stanowiły 352\% średniej miesięcznej sumy opadów (Świątek, 2013a).

Wysokie, w tym także ekstremalne sumy opadów atmosferycznych w Polsce związane są niewątpliwie z działalnością niżów śródziemnomorskich.

Celami tej części opracowania są: ocena średniej wysokości opadów o genezie śródziemnomorskiej (dalej: opadów $M C P$ ) na obszarze Polski, określenie udziału $M C P$ w ogólnej sumie opadów atmosferycznych w Polsce oraz określenie sezonowej zmienności MCP w Polsce. Sprawdzono kilka prostych hipotez badawczych:

1) wysokość i udział $M C P$ w sumie ogólnej opadów w Polsce zmienia się sezonowo, odpowiednio do zmian występowania w ciągu roku układów $M E C$, których częstość wzrasta na wiosnę i w jesieni (Degirmendžić i Kożuchowski, 2014); podobna korelacja dotyczy wieloletnich zmian wysokości opadów MCP i trendu częstości występowania cyklonów $M E C$;

2) sumy dobowe „opadów śródziemnomorskich” należą do najwyższych w Polsce, a więc udział MCP w całkowitych sumach opadowych wzrasta wraz z wysokością tych sum;

3) zróżnicowanie przestrzenne opadów $M C P$ na obszarze Polski kształtuje się pod wpływem oddziaływania barier orograficznych Karpat i Sudetów; zarówno sumy bezwzględne, jak i udział MCP w całkowitych sumach opadu są najwyższe w górach i na obszarach przedgórskich kraju, tj. w Polsce Południowej i Południowo-Zachodniej.

\section{Materiał analizy opadów o genezie śródziemnomorskiej}

W analizie opadów atmosferycznych wykorzystano serie sum dobowych opadu z okresu 1958-2008, pochodzące z 66 stacji meteorologicznych, z których 13 reprezentuje góry i „obszar przedgórski” (rys. 3.2).

W celu wyróżnienia opadów o genezie śródziemnomorskiej w Polsce $(M C P)$ zastosowano kryterium, według którego za „opad śródziemnomorski” uznano opad dobowy, który wystąpił na danej stacji w Polsce w dniu, kiedy 
centrum cyklonu śródziemnomorskiego znajdowało się najbliżej tej stacji w porównaniu z pozycją innych układów cyklonalnych, rozwijających się tego dnia na półkuli północnej. Obliczono wartość ortodromy, łączącej stację notującą opad z centrum każdego cyklonu. Jeśli najmniejsza wartość ortodromy dotyczyła cyklonu $M E C$ - opad w danej stacji zaklasyfikowano do klasy „opadów śródziemnomorskich" (MCP).

Centra cyklonów $M E C$ generujących opady śródziemnomorskie w Polsce są oddalone od stacji rejestrującej opad MCP najczęściej o 300-400 km (rys. 5.1). Jest to odległość, odpowiadająca w przybliżeniu dystansowi, dzielącemu granice Polski od miejsca na trajektorii cyklonów śródziemnomorskich, uznanego według niezależnego kryterium (Degirmendžić i in., 2014) za ich położenie odpowiadające najwyższym opadom w Polsce (rys. 5.2). Punkt ten znajduje się w pobliżu granicy węgiersko-rumuńskiej, na $21^{\circ}$ E i $47^{\circ} \mathrm{N}$.

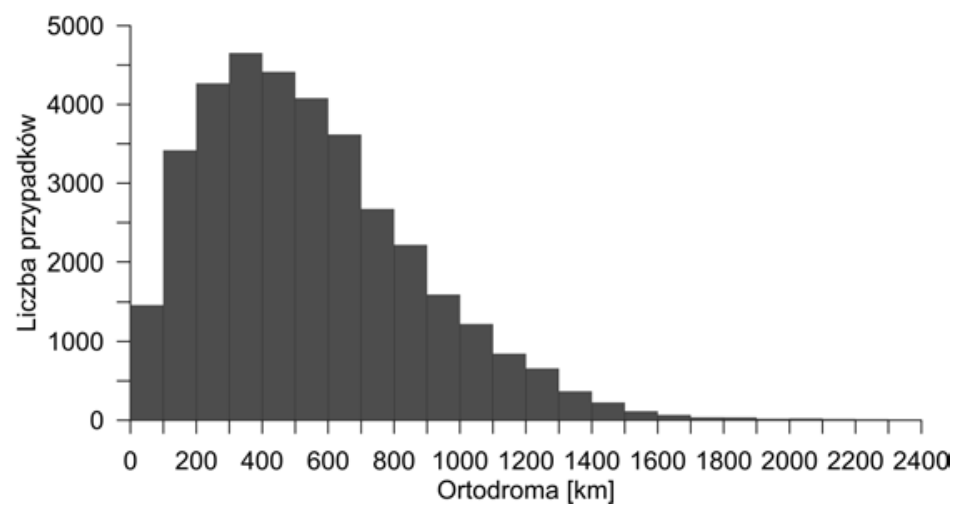

Rys. 5.1. Rozkład wartości ortodrom [km] określających odległość stacji, na której wystąpił opad MCP od położenia centrum niżu śródziemnomorskiego ( $M E C)$.

Okres 1958-2008 (wg Degirmendžića i Kożuchowskiego, 2015a)

Niemniej, przyjęta metoda kwalifikacji opadów śródziemnomorskich nie uwzględniająca specyfiki sytuacji synoptycznej (na przykład położenia frontów, linii nieciągłości, stref dodatniej adwekcji wirowości w wyższych warstwach atmosfery itp.) nie wskazuje na rodzaj procesu, formującego opad. Wskazuje jedynie na możliwy udział znajdującego się najbliżej obszaru Polski cyklonu $M E C \mathrm{w}$ generowaniu strefy opadów. Biorąc pod uwagę średnie rozmiary frontów, związanych z niżami, można przypuszczać, że w większości przypadków przedstawionych na rys. 5.1, strefy opadów mogły się znajdować nie dalej niż $300 \mathrm{~km}$ od linii frontu, czyli mogły mieć charakter frontalny. W przypadkach bardziej oddalonych układów MEC (np. >1000 km) frontalna geneza opadów jest mniej prawdopodobna. 


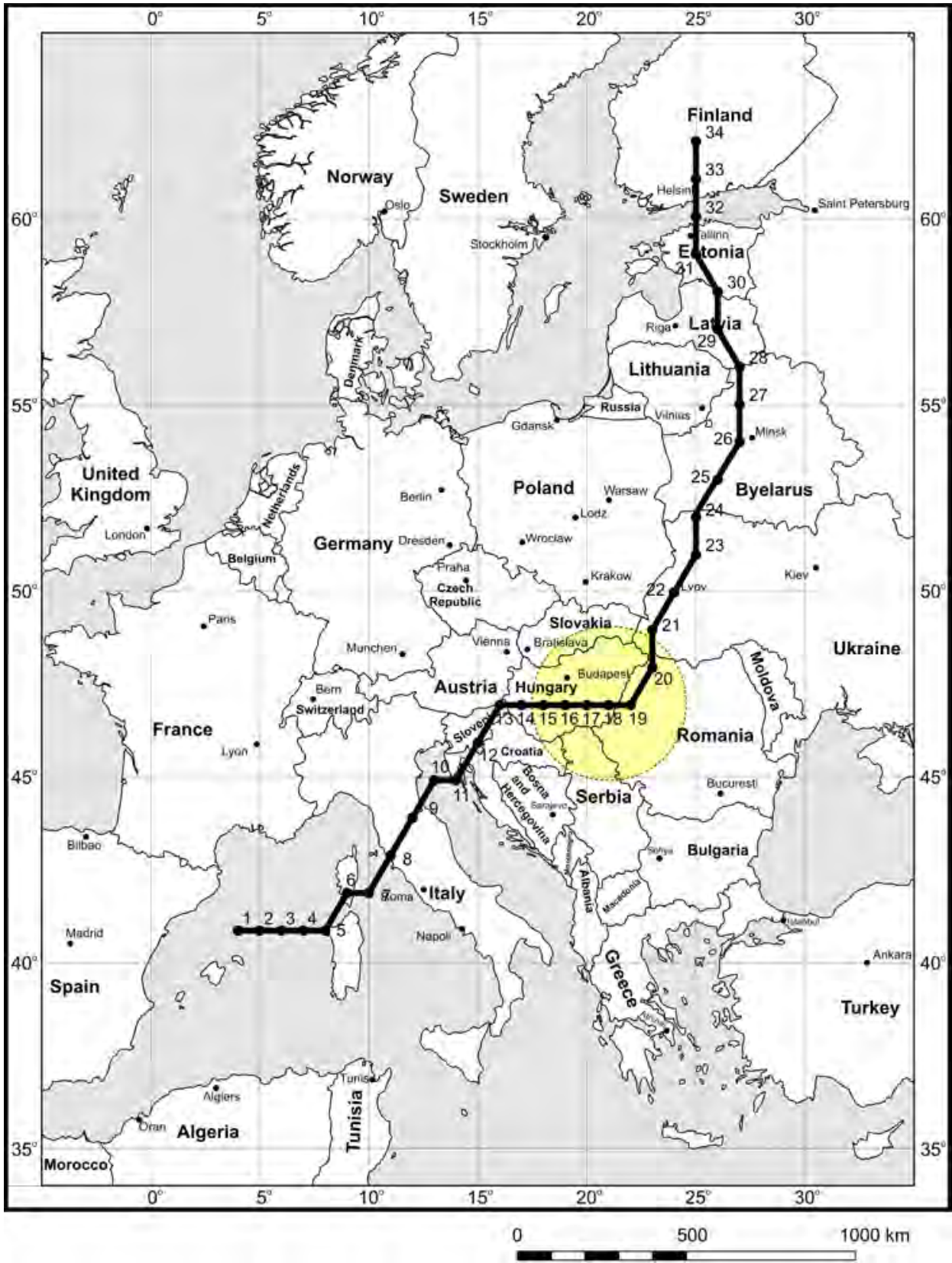

Rys. 5.2. Średnie położenie toru Vb niżów śródziemnomorskich (MEC) oraz usytuowanie obszaru (okrąg o promieniu $250 \mathrm{~km}$ i środku w danym punkcie trajektorii), z którym związane są najwyższe opady $M C P$ na obszarze Polski (wg Degirmendžića i in., 2014) 
Zauważono jednak, że nawet znacznie oddalone od Polski cyklony śródziemnomorskie przyczyniają się do wystąpienia opadów na terytorium kraju. Przykładem może być sytuacja pogodowa z dnia 23.03.2014 r., kiedy niż usytuowany nad Zatoką Genueńską, czyli w typowym miejscu cyklogenezy układów $M E C$, łączył się bruzdą obniżonego ciśnienia z niżem znad Bałtyku. Opady występujące wówczas w rejonach górskich południowej Polski związane były z zaburzeniem zachodniego przepływu i rozwijająca się linią zbieżności prądów powietrza w obrębie bruzdy, a w przepływie powietrza nad Sudetami dominowała składowa północna.

Analizując wyróżnione opady MCP obliczono ich sumy roczne, sezonowe (miesiące III-V, VI-VIII, IX-XI i XII-II) oraz pentadowe w poszczególnych stacjach, sumy uśrednione dla całej Polski (66 stacji) oraz sumy uśrednione dla obszarów górskich i przedgórskich (13 stacji) i pozostałej części kraju (53 stacje). Udział $M C P \mathrm{w}$ rozkładzie całkowitych sum opadów wyznaczono trzema sposobami: 1) obliczono ilorazy sum pentadowych, sezonowych oraz rocznych opadów MCP i odpowiednich całkowitych sum opadów z tych okresów, które wskazują, jaka część występujących w Polsce opadów ma genezę śródziemnomorską, 2) na podstawie całkowitych sum opadów wyznaczono decyle rozkładu opadów w każdej stacji, a następnie obliczono udział opadów $M C P$ w zakresach opadów określonych przez wartości decyli, 3) obliczono udział MCP w przyjętych jednolitych przedziałach opadu (0-10, 10-20, 20-30 mm itd.).

\section{Udział opadów o genezie śródziemnomorskiej w całkowitych sumach opadów}

W tab. 5.1 przedstawiono wyniki obliczeń wysokości opadów o genezie śródziemnomorskiej $(M C P)$ na tle całkowitych sum opadów atmosferycznych w Polsce. Podano średnie wieloletnie (1958-2008) sumy sezonowe i roczne opadów, uśrednionych dla całego obszaru kraju (66 stacji), dla obszarów górskich i przedgórskich oraz dla pozostałej części kraju - „Polski nizinnej”. Tabela informuje jaką część występujących w Polsce opadów stanowią MCP i jakie są sezonowe zmiany udziału opadów $M C P$ w całkowitych sumach opadowych. Mapy zamieszczone na rys. 5.4 przedstawiają przestrzenny rozkład udziału opadów MCP w rocznych i sezonowych sumach opadów na terenie kraju.

Całkowita średnia roczna suma opadów w Polsce nizinnej (605 mm) zawiera 55 mm (tj. 9,1\%) opadów o genezie śródziemnomorskiej. W górach i na 
obszarach przedgórskich średnia suma MCP wynosi $112 \mathrm{~mm}$ (tj. 11\% sumy rocznej). Dla całego kraju udział ten wynosi 9,6\%, co oznacza, że średnio w roku na obszar Polski spada ponad $66 \mathrm{~mm}$ opadu o genezie śródziemnomorskiej. Jest to więcej, niż wynosi przeciętna suma miesięczna opadów w Polsce i więcej niż spada w maju (średnio $58 \mathrm{~mm}$ ) lub we wrześniu (52 mm) i tyle co 3/4 średnich opadów w lipcu.

Tab. 5.1. Średnie sezonowe i roczne sumy opadów o genezie śródziemnomorskiej

$(M C P)$, całkowite sumy opadów i udział MCP w całkowitych sumach opadów na obszarze Polski, na obszarach górskich i przedgórskich oraz w pozostałej części Polski (1958-2008) (wg Degirmendžića i Kożuchowskiego, 2015a)

\begin{tabular}{llrrrrr}
\hline Obszar & Średni opad & Wiosna & Lato & Jesień & Zima & Rok \\
\hline \multirow{4}{*}{ Polska } & MCP $(\mathrm{mm})$ & 21,3 & 21,4 & 15,8 & 7,6 & 66,2 \\
& całkowity $(\mathrm{mm})$ & 150,9 & 256,3 & 160,5 & 119,1 & 686,8 \\
& udział MCP $(\%)$ & 14,1 & 8,4 & 9,9 & 6,4 & 9,6 \\
\hline \multirow{3}{*}{$\begin{array}{l}\text { Obszary górskie } \\
\text { i przedgórskie }\end{array}$} & MCP $(\mathrm{mm})$ & 36,1 & 38,8 & 24,9 & 12,5 & 112,4 \\
& całkowity $(\mathrm{mm})$ & 233,3 & 400,9 & 220,5 & 164,8 & 1019,5 \\
& udział MCP (\%) & 15,5 & 9,7 & 11,3 & 7,6 & 11,0 \\
\hline \multirow{3}{*}{$\begin{array}{l}\text { Pozostała część } \\
\text { Polski }\end{array}$} & MCP $(\mathrm{mm})$ & 17,7 & 17,1 & 13,6 & 6,4 & 54,9 \\
& całkowity (mm) & 130,7 & 220,8 & 145,7 & 107,9 & 605,2 \\
& udział MCP (\%) & 13,6 & 7,8 & 9,3 & 5,9 & 9,1 \\
\hline
\end{tabular}

Udział opadów MCP w strukturze rozkładu dobowych sum opadowych wzrasta wraz w wysokością tych sum (rys. 5.3). Opady dobowe o wysokości należącej do 10 decyla (1/10 obserwowanych sum opadu o maksymalnej wysokości) zawierają średnio w Polsce 12,8\% opadów o genezie śródziemnomorskiej. Niższe sumy (1-9 decyl) - od 5 do 8\% opadów MCP (rys. 5.3). Aż 23,7\% opadów należących do przedziału sum dobowych 80-90 mm ma genezę śródziemnomorską. Stwierdzono ponadto, że począwszy od zakresu sum opadu 50-60 mm/dobę można znaleźć w Polsce dość liczne stacje, w których opady MCP stanowią całą sumę opadu całkowitego.

Największymi udziałami MCP w sumie rocznej opadów charakteryzuje się Polska Południowo-Zachodnia (Kłodzko 14\%, Legnica 13,5\%, Jelenia Góra 13,3\%, Racibórz 12,9\%, Żywiec 12,7\%, Śnieżka i Wrocław 12,3\%) oraz wschodni obszar obejmujący Lubelszczyznę (Lublin 11\%). Na Wybrzeżu 
udział opadów MCP jest najmniejszy: w Łebie wynosi on zaledwie 5,6\%, w Ustce 5,7\%, w Świnoujściu 5,8\% (rys. 5.4).

W okresie wiosennym dobowa częstość występowania układów MEC jest najwyższa (wynosi 2,7\%) i zarazem udział MCP w sumach opadów sezonowych osiąga największe wartości: w całej Polsce wynosi 14,1\%, w górach - 15,5\% (tab. 5.1). Maksima tego udziału stwierdzono w Kłodzku (19,8\%), w Raciborzu (19,0\%), na Śnieżce (18,2\%), w Legnicy $(18,0 \%)$ i w Opolu $(17,9 \%)$. Na mapie udziału MCP (rys. 5.4) w całkowitych sumach opadów wiosennych widać, jak maleje on z południa na północ kraju; przede wszystkim zmniejsza się w kierunku od Sudetów i ich Przedgórza do Pomorza Zachodniego (w Koszalinie stanowi 8,8 \% całkowitej sumy opadów) i od Karpat do Mazur i Suwalszczyzny (w Mikołajkach wynosi 10,7\%).
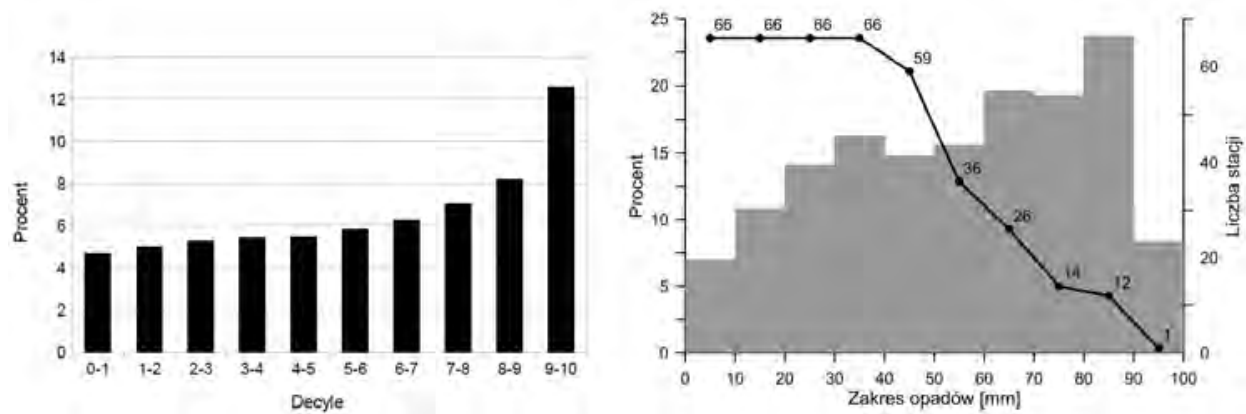

Rys. 5.3. Udział procentowy dobowych sum $M C P$ w całkowitych sumach opadów na obszarze Polski: według decyli rozkładu sum dobowych (lewy wykres) i według przedziałów sum dobowych 0-10, 10-20, 20-30 mm itd. (przedziały prawostronnie domknięte; prawy wykres). Na prawym wykresie zaznaczono liczbę stacji meteorologicznych, na których zanotowano opad MCP

(wg Degirmendžića i Kożuchowskiego, 2015a)

W sezonie letnim maksymalne udziały $M C P$ w sumach opadów sezonowych najwyraźniej związane są z Sudetami (Jelenia Góra 13,8\%, Śnieżka i Legnica $13 \%$, rys. 5.4). Najmniejsze udziały opadów tego typu pojawiają się na północy kraju: w Olsztynie 5,6\%, w Goleniowie 5,3\%, w Świnoujściu zaledwie $5 \%$. Zarówno najwyższe, jak i najniższe opady $M C P$ w okresie letnim są większe niż na wiosnę, ale ich udział w całkowitych sumach opadów w tym sezonie jest mniejszy; podobnie jak mniejsza jest letnia częstość niżów śródziemnomorskich od ich częstości na wiosnę (odpowiednio 1,5 i 2,7\%). W skali krajowej udział opadów letnich o genezie śródziemnomorskiej w całkowitej sumie opadów wynosi 8,4\%, na obszarze gór i ich przedpolach - 9,7\% (tab. 5.1). 
W sezonie jesiennym udział $M C P$ w sumach sezonowych ponownie wzrasta i w przeważającej części Polski przekracza 10\%, dochodząc do 16,5\% w Kłodzku i 15\% w Żywcu (rys. 5.4). W jesieni, podobnie jak na wiosnę, wysoki udział MCP w całkowitych sumach opadowych występuje też we wschodniej części kraju; w Lublinie i Sandomierzu przekracza on 13\%, w Siedlcach wynosi 12,9, w Terespolu 12,6\%. Na Wybrzeżu i Pomorzu udział ten jest najmniejszy: w Ustce wynosi 4,9\%, w Resku, Łebie i Kołobrzegu 5,2\%, w Lęborku 5,4\%. Średni udział jesiennych opadów MCP w Polsce wynosi 9,9\%, w górach i na obszarach przedgórskich - 11,3\% i jest nieco niższy niż na wiosnę, odpowiednio do zmniejszonej liczby układów cyklonalnych $M E C$ w tej porze roku $(1,7 \%)$.

W zimie częstość $M E C$ jest najmniejsza $(1,4 \%)$, najniższy jest też udział MCP w sumach opadów zimowych: na obszarze Polski waha się on od $11 \%$ w Sandomierzu, 10,6\% w Kłodzku i 10,5\% w Żywcu do zaledwie 3,1\% w Ustce i 3,3\% w Szczecinie i w Świnoujściu (rys. 5.4). Średnia wartość krajowa udziału opadów MCP $w$ zimowych sumach opadu wynosi 6,4\%, w górach $-7,6 \%$ (tab. 5.1).

Sezonowe wartości udziału $M C P$ w całkowitych sumach opadów sezonowych korelują najwyraźniej z częstością występowania MEC: są największe na wiosnę i w jesieni. Bezwzględne wysokości opadów $M C P$ w sezonie letnim są jednak zbliżone lub nawet nieco wyższe niż na wiosnę. Uwzględniając sezonową częstość występowania układów $M E C$ generujących „opady śródziemnomorskie" w Polsce można dowieść, że obfitość opadów MCP jest największa w sezonie letnim. Jeden cyklon śródziemnomorski przynosi w Polsce średnio prawie $16 \mathrm{~mm}$ opadu w okresie lata, $9 \mathrm{~mm}$ w jesieni i na wiosnę oraz $6 \mathrm{~mm}$ w zimie. Częstość opadów śródziemnomorskich w sezonie letnim nie jest wielka (średnio 2-3 dni z opadem $M C P$ ), ale ich obfitość jest w tym sezonie największa.

\section{Obfitość opadów o genezie śródziemnomorskiej}

Obfitość opadów jest wskaźnikiem, określającym średnią sumę opadu w dniach z opadem; według Kosiby (1972) jest to miara „średniej wydajności dnia opadowego". Na podstawie danych z literatury można stwierdzić, że na obszarze Polski średnia roczna obfitość opadów wynosi od 3 do $4 \mathrm{~mm} / \mathrm{dobę,}$ jedynie na południu kraju przekracza $4 \mathrm{~mm} /$ dobę, wysoko w górach sięgając prawie do $8 \mathrm{~mm} /$ dobę (Tamulewicz, 1993). 

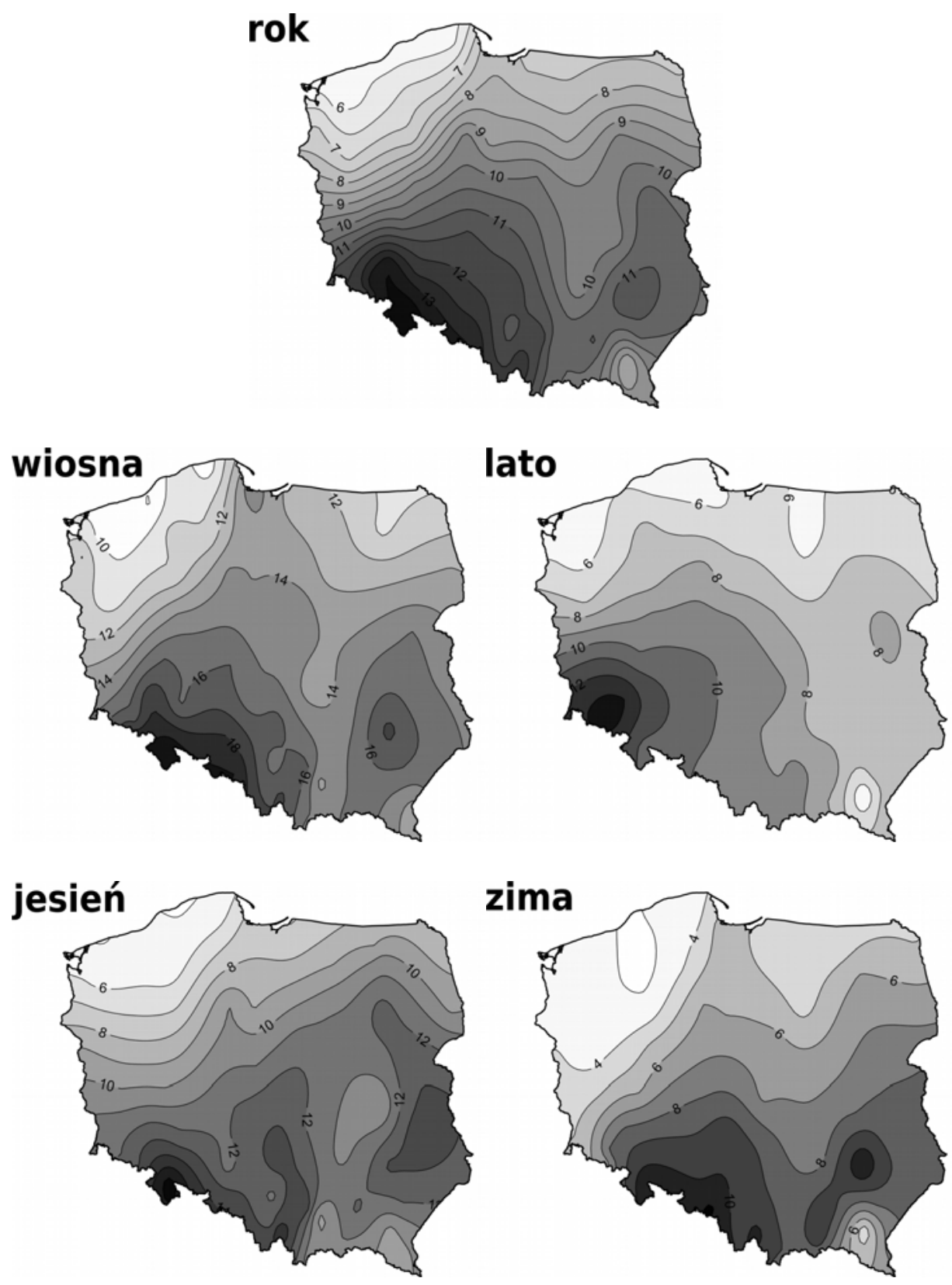

Rys. 5.4. Średni udział MCP [\%] w całkowitych sumach opadów rocznych i sezonowych na obszarze Polski w okresie 1958-2008 (wg Degirmendžića i Kożuchowskiego, 2015a) 
W miesiącach letnich średnia obfitość opadów wzrasta do 5-6 mm/dobę, w Tatrach przekracza $10 \mathrm{~mm} /$ dobę. W sezonie od listopada do marca obfitość opadów zmniejsza się i na ogół nie przekracza średnio $3 \mathrm{~mm} /$ dobę, a w górach 5-6 mm/dobę (Kożuchowski, 2015a).

Wskaźnik obfitości opadów stanowi istotną informację o opadach śródziemnomorskich, zwłaszcza w odniesieniu do ich przestrzennego zróżnicowania w Polsce oraz zmian sezonowych. Według opinii Tamulewicza (1993), wskaźnik ten umożliwia też porównanie średniego natężenia opadów. Warto też dodać, że średnia obfitość opadów jest wprost proporcjonalna do średniej zawartości wilgoci w atmosferze (precipitable water).

Tab. 5.2. Całkowita liczba dni z opadem, liczba dni z opadem MCP i obfitość tych opadów [mm/doba] (wg Degirmendžića i Kożuchowskiego, 2015a)

\begin{tabular}{|c|c|c|c|c|c|c|}
\hline Obszar & Charakterystyki opadów & Wiosna & Lato & Jesień & Zima & Rok \\
\hline \multirow{4}{*}{ Polska } & Liczba dni z opadem & 39,7 & 40,5 & 40,8 & 47,1 & 168,1 \\
\hline & Obfitość opadów & 3,8 & 6,3 & 4,2 & 2,5 & 4,1 \\
\hline & Liczba dni z opadem MCP & 3,98 & 2,35 & 2,77 & 2,24 & 11,35 \\
\hline & Obfitość opadów MCP & 5,4 & 9,1 & 5,7 & 3,4 & 5,8 \\
\hline \multirow{4}{*}{$\begin{array}{l}\text { Góry } \\
\text { i pogórza }\end{array}$} & Liczba dni z opadem & 49,5 & 48,8 & 44,9 & 50,1 & 193,3 \\
\hline & Obfitość opadów & 4,7 & 8,2 & 4,9 & 3,3 & 5,3 \\
\hline & Liczba dni z opadem MCP & 4,93 & 3,14 & 3,40 & 2,56 & 14,05 \\
\hline & Obfitość opadów MCP & 7,3 & 12,4 & 7,3 & 4,9 & 8,0 \\
\hline \multirow{4}{*}{ Niziny } & Liczba dni z opadem & 38,8 & 39,7 & 36,6 & 47,4 & 162,5 \\
\hline & Obfitość opadów & 3,4 & 5,5 & 3,9 & 2,3 & 3,7 \\
\hline & Liczba dni z opadem MCP & 3,75 & 2,15 & 2,62 & 2,16 & 10,68 \\
\hline & Obfitość opadów MCP & 4,7 & 8,0 & 5,2 & 3,0 & 5,1 \\
\hline
\end{tabular}

Tab. 5.3. Ilorazy obfitości opadów MCP i pozostałej części opadów (wg Degirmendžića i Kożuchowskiego, 2015a)

\begin{tabular}{lrrrrr}
\hline Obszar & Wiosna & Lato & Jesień & Zima & Rok \\
\hline Polska & 1,49 & 1,50 & 1,35 & 1,36 & 1,47 \\
Góry i pogórza & 1,68 & 1,56 & 1,56 & 1,52 & 1,58 \\
Niziny & 1,48 & 1,48 & 1,35 & 1,31 & 1,42 \\
\hline
\end{tabular}


W tab. 5.2 zamieszczono sezonowe i roczne wysokości opadów dobowych, uśrednione dla całego obszaru Polski, regionu gór i pogórzy oraz dla Polski nizinnej. Średnioroczna obfitość opadów o genezie śródziemnomorskiej jest wyraźnie wyższa od obfitości wyznaczonej na podstawie całkowitych sum opadowych i łącznej liczby dni z opadami. „Nadwyżka” ta występuje we wszystkich porach roku, tak w górach jak i w nizinnej części kraju. Średnia roczna obfitość wszystkich opadów w Polsce w okresie 1958-2008 wynosiła 4,1 mm/dobę, na obszarze górskim i podgórskim 5,3, w nizinnej części kraju 3,7 mm/dobę, natomiast obfitość opadów śródziemnomorskich wynosiła odpowiednio 5,8, 8,0 i 5,1 mm/dobę (tab. 5.2). Przewagę obfitości opadów śródziemnomorskich nad obfitością pozostałych opadów - o innej genezie - wyrażają ilorazy obu tych wielkości, zamieszczone w tab. 5.3. Na tej podstawie można ocenić, że obfitość MCP stanowi około 150\% obfitości opadów, związanych z działaniem pozostałych procesów opadotwórczych. Na wiosnę, w obszarze górskim średnia obfitość opadów śródziemnomorskich wzrasta do 168\% wartości, charakteryzującej inne, „nie śródziemnomorskie” opady.

Obfitość MCP ma wyraźny cykl roczny z letnim maksimum, podobny do cyklu zmian całkowitych sum opadów i ich obfitości w ciągu roku. Można ponadto zauważyć, że amplituda rocznych zmian obfitości opadów śródziemnomorskich jest nieco większa od amplitudy zmian całkowitych sum opadu: iloraz obfitości $M C P$ lata i zimy w Polsce wynosi 2,67, podczas gdy iloraz obfitości całkowitych sum opadów w tych sezonach wynosi 2,52. Na wiosnę obfitość opadów MCP jak i całkowitych jest nieco mniejsza niż w jesieni, jedynie na obszarze górskim w obu tych sezonach obfitość $M C P$ jest równa (tab. 5.2). Na mapach (rys. 5.5) przedstawiono obrazy przestrzennego zróżnicowania obfitości opadów o genezie śródziemnomorskiej na obszarze Polski w ciągu roku i w sezonach. Generalną cechą tego zróżnicowania jest gradient obfitości $M C P$ skierowany z południa (ściślej: z SSW) na północ i przyjmujący najwyższe wartości na obszarze pogórzy i obniżeń przedgórskich, gdzie kontrasty tego wskaźnika opadów są największe.

Średnia roczna obfitość $M C P$ (rys. 5.5) maleje od 11-12 mm/dobę w Tatrach i $10 \mathrm{~mm}$ na Śnieżce do około $6 \mathrm{~mm}$ na Pogórzu Karpackim i na Nizinie Śląskiej. Na terenach Polski nizinnej obfitość $M C P$ wynosi około 5-6 mm/dobę z opadem, na Wybrzeżu i na Pomorzu - zmniejsza się do około $4 \mathrm{~mm} /$ dobę, wszędzie jest jednak większa od obfitości całkowitych sum opadowych i stanowi przeważnie blisko $150 \%$ jej wartości.

Na wiosnę (rys. 5.5) największa obfitość opadów MCP występuje w górach (Hala Gąsienicowa 11, Kasprowy Wierch, Śnieżka $9 \mathrm{~mm} /$ dobę). Dość 
wysoka obfitość (około $5 \mathrm{~mm} /$ dobę) charakteryzuje $M C P$ pojawiające się w pasie Polski Południowej, łącznie z południową Wielkopolską, Niziną Śląską oraz Wyżyną Lubelską. Obfitość MCP na Wybrzeżu i Ziemi Lubuskiej (Gorzów Wlkp.) maleje do $4 \mathrm{~mm} /$ dobę.

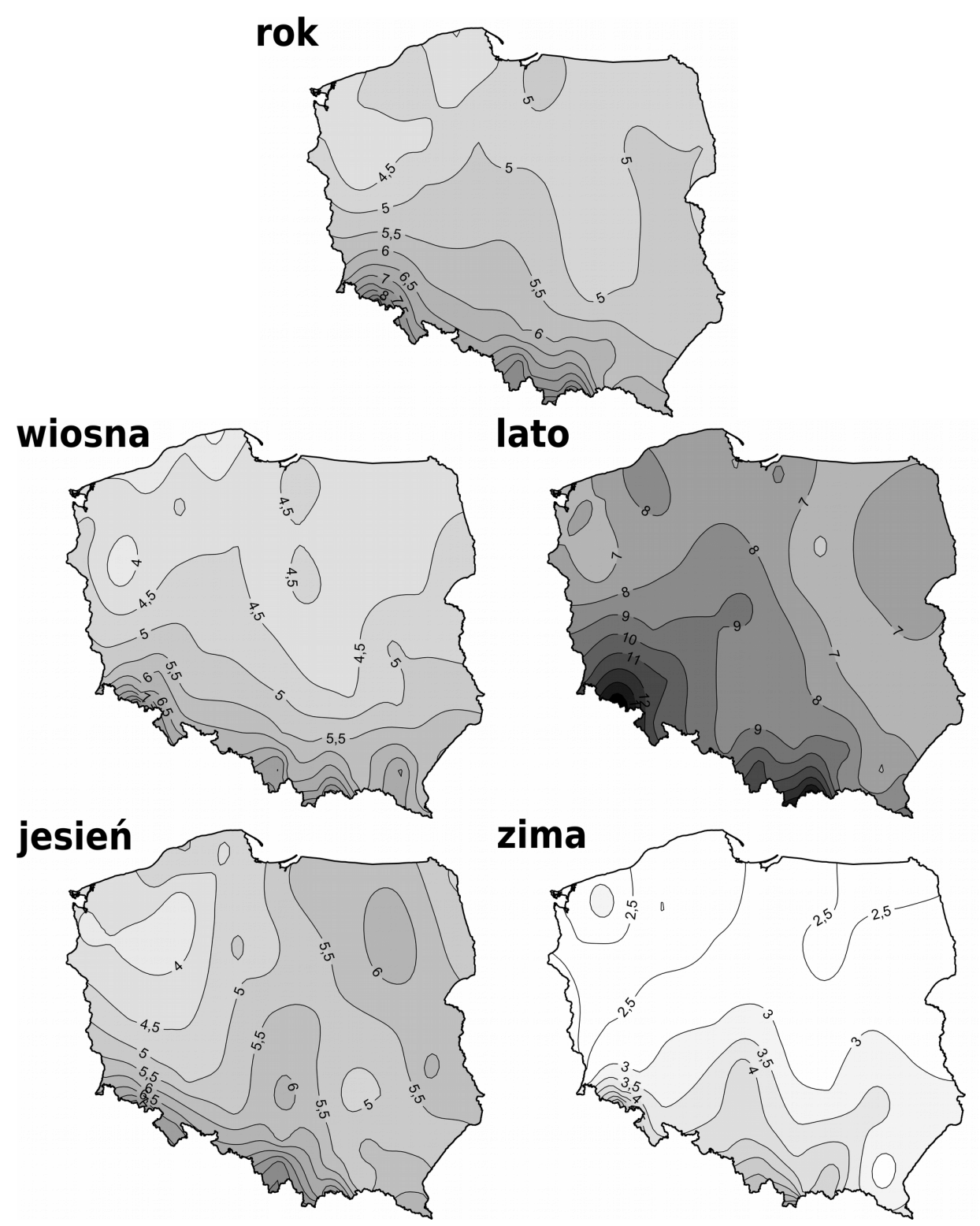

Rys. 5.5. Średnia roczna i sezonowa obfitość $M C P$ w Polsce [mm/doba] w okresie 1958-2008 (wg Degirmendžića i Kożuchowskiego, 2015a) 
Letni obraz zróżnicowania obfitości $M C P$ wykazuje istnienie dużego kontrastu między Polską Południowo-Zachodnią a wschodnią i północną częścią kraju. Izolinia $8 \mathrm{~mm} /$ dobę obejmuje cały obszar, leżący na południe i na zachód od Poznania, Torunia, Sulejowa i Tarnowa. Najwyższe wartości są w Tatrach i Karkonoszach (Hala Gąsienicowa 19 mm, Kasprowy 17, Śnieżka $15 \mathrm{~mm} /$ dobę), względnie dużą obfitością charakteryzują się rejony podgórskie i leżące dość daleko na przedpolu gór (Bielsko Biała i Legnica 12, Wrocław i Częstochowa 11, Kalisz $9 \mathrm{~mm} /$ dobę). Nawet w Toruniu i Poznaniu średnia obfitość opadów MCP przekracza $8 \mathrm{~mm} /$ dobę, podobnie wysokie wartości pojawiają się w środkowej części Pojezierza Pomorskiego (w Chojnicach, Szczecinku i w Koszalinie). Słabiej zarysowany obszar dość dużej obfitości MCP (>7 mm/dobę) leży w północno-wschodniej części kraju. Najmniejsze wartości (6 mm/dobę) odnotowano w Świnoujściu i w Mławie (rys. 5.5).

W jesieni „opady śródziemnomorskie” o największej obfitości występują w górach (Hala Gąsienicowa 10, Kasprowy Wierch 9, Śnieżka 8 mm/dobę) i w pasie, ciągnącym się od Beskidu Żywieckiego (Żywiec 8, Bielsko-Biała $9 \mathrm{~mm} /$ dobę) przez Górny Śląsk i Wyżynę Częstochowską aż po Łódź (Katowice, Częstochowa i Łódź $6 \mathrm{~mm} /$ dobę). Drugi pas podwyższonej obfitości MCP biegnie przez Polskę Wschodnią - od Wyżyny Lubelskiej przez Podlasie aż po Mazury. Średnia obfitość MCP w tym pasie przekracza miejscami (np. w Lublinie i Ostrołęce) $6 \mathrm{~mm} /$ dobę. Najmniejszą obfitość (około 3,5 mm/dobę) wykazują w jesieni opady $M C P$ na Pomorzu Zachodnim (rys. 5.5).

W zimie obfitość $M C P$ jest najmniejsza; w północnej połowie Polski nie osiąga $3 \mathrm{~mm} /$ dobę. Większa jest w górach, zwłaszcza w Tatrach (Kasprowy Wierch $9 \mathrm{~mm} /$ dobę) i w Karkonoszach (Śnieżka $7 \mathrm{~mm} /$ dobę). Pasma względnie dużej obfitości zimowych opadów $M C P$ rozciągają się z południa na północ przez Polskę Środkową oraz przez wschodnią część kraju (rys. 5.5).

Izarytmy obfitości „opadów śródziemnomorskich”, poza tym, że odzwierciedlają występowanie najobfitszych opadów w górach, ujawniają skłonność do pasmowego, w przybliżeniu południkowego układu obfitości opadów MCP. W układzie wartości sezonowych, a także i rocznych, można zauważyć istnienie dwóch pasm podwyższonej obfitości $M C P$ : pasmo zachodnie od podnóża Sudetów i Beskidów Zachodnich rozciąga się nad Wielkopolskę, drugie, bardziej zmienne w ciągu roku pasmo (wschodnie) lokuje się we wschodniej bądź północno-wschodniej Polsce. Południkowy przebieg mają strefy maksymalnych opadów w Polsce; przykład podali już Mycelska i Michalczewski (1972), którzy pokazali rozmieszczenie sum nawalnych opadów w lipcu 1970 roku, związanych z „południowoeuropejską” cyrkulacją cyklonalną i powodujących 
powódź w dorzeczu Wisły. O istnieniu dwu szlaków nawalnych opadów, biegnących od Sudetów i Karpat na północ, pisali też Kożuchowski i Wibig (1988). Nakładanie się tych południkowo zorientowanych szlaków opadów nawalnych i równoleżnikowo przebiegających stref średnich sum opadowych, związanych w znacznej części z rzeźbą podłoża atmosfery (wybrzeże i pojezierza, niziny, wyżyny, góry) tworzy w Polsce „rusztowy” charakter pola opadów (Kożuchowski, 2010). Opady MCP charakter ten współkształtują. Obraz pola najwyższej miesięcznej sumy opadów o genezie śródziemnomorskiej w Polsce (sierpień 1972 r., średnia opadu MCP w Polsce 69,4 mm) stanowi potwierdzenie tej tezy: wyraźnie rysują się dwa południkowe pasma najwyższych opadów, które ciągną się wzdłuż wschodniej granicy kraju oraz wzdłuż linii, biegnącej od Beskidu Żywieckiego przez Polskę Środkową aż po Zalew Wiślany (rys. 5.6).

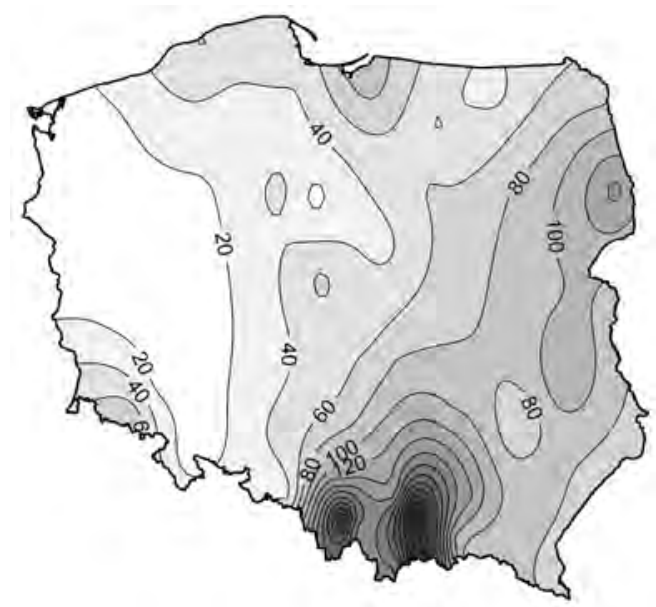

Rys. 5.6. Sumy miesięczne MCP [mm] w Polsce w sierpniu 1972 r. (wg Degirmendžića i Kożuchowskiego, 2015a)

\section{Sezonowe zmiany opadów o genezie śródziemnomorskiej}

Analiza średnich sezonowych wysokości opadów o genezie śródziemnomorskiej, ich udziału w całkowitych sumach opadów oraz średniej obfitości MCP wskazuje na istnienie różnych rytmów zmian tych wskaźników opadu w ciągu roku. Wysokość opadu (sumy sezonowe $M C P$ ) jest najwyższa w lecie i na wiosnę, udział opadów $M C P$ w sumach całkowitych ma maksima wiosną 
i jesienią, a obfitość MCP osiąga największe wartości w sezonie letnim. Wartości sezonowe tworzą jednakże tylko zgeneralizowany obraz rocznego rytmu zmian opadów. W celu uzyskania bardziej szczegółowych danych o sezonowej zmienności MCP wykorzystano średnie sumy pentadowe opadów. Uwzględniono ich uśrednione wartości z całego obszaru Polski.

Średnie pentadowe sumy opadów o genezie śródziemnomorskiej z wielolecia 1958-2008 odznaczają się znaczną zmiennością w ciągu roku, której przyczyną jest z jednej strony mała częstość zdarzeń opadu MCP, co sprawia, że obraz ich rocznego przebiegu jest dość chaotyczny, a z drugiej - wspomniane już rytmy częstości występowania, wysokości i obfitości $M C P$ powodują, iż sumy pentadowe wahają się w zależności od interferencji tych rytmów.

Na rys. 5.7 przedstawiono roczne przebiegi średnich pentadowych sum opadów $M C P$ na tle średnich całkowitych sum opadów w Polsce. Najwyższa suma 5-dniowa plasuje się w 20 pentadzie, tj. w okresie 6-10 kwietnia. Jej średnia wysokość (blisko $3 \mathrm{~mm}$ ) stanowi 1/3 średniej całkowitej sumy opadów, które wystąpiły w tych dniach. Kolejne najwyższe sumy pentadowe $M C P$ występują w 44, 48, 31 i 58 pentadzie, tj. odpowiednio w dniach 4-8.08, 24-28.08, 31.05-4.06 i 13-17.10. Udział tych sum kształtuje się na poziomie około $20 \%$ całkowitych sum opadów w Polsce.

Przebieg roczny sum pentadowych pozwala zatem wyróżnić dwie główne fazy nasilenia opadów o genezie śródziemnomorskiej w Polsce: pierwsza rozpoczyna się w 15. pentadzie roku (12-16.03.) kiedy to opady MCP zaczynają wzrastać po depresji zimowej, druga rozwija się na początku sierpnia i utrzymuje się aż do końca roku kalendarzowego. W tej fazie wysokości opadów MCP stopniowo maleją, ale ich udział w całkowitych sumach opadów utrzymuje się na dość wysokim poziomie, okresami przekraczając znacznie średnioroczną wartość 9,6\% (rys. 5.7c). Uwzględniając wygładzone przez średnią ruchomą wysokości opadów $M C P$, maksimum pierwszej fazy można zlokalizować w końcu kwietnia (21-25.04), maksimum drugiej - w połowie sierpnia (14-18.08). Osobliwością rocznego przebiegu wysokości opadów MCP jest depresja od końca czerwca do końca lipca. Zaznacza się ona szczególnie w odniesieniu do wysokich całkowitych sum opadowych tego okresu. Druga taka depresja obejmuje miesiące zimowe - styczeń i luty (rys. 5.7a). Oba te minima wiążą się zapewne z nasiloną cyrkulacją strefową, która nie sprzyja przemieszczaniu się na północ cyklonów śródziemnomorskich. Minimum zimowe można ponadto tłumaczyć obniżoną w tym sezonie zawartością wilgoci w atmosferze i stabilnością stratyfikacji termicznej, czyli warunkami nie sprzyjającymi powstawaniu dużych opadów. 
a)

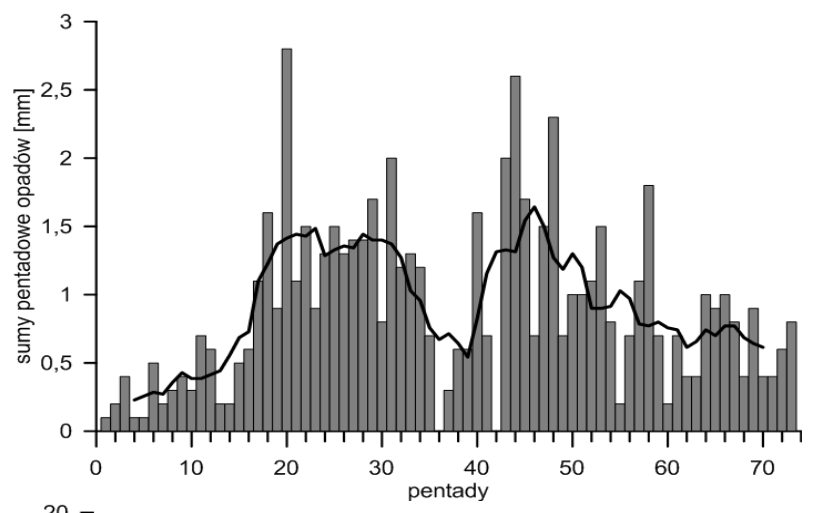

b)

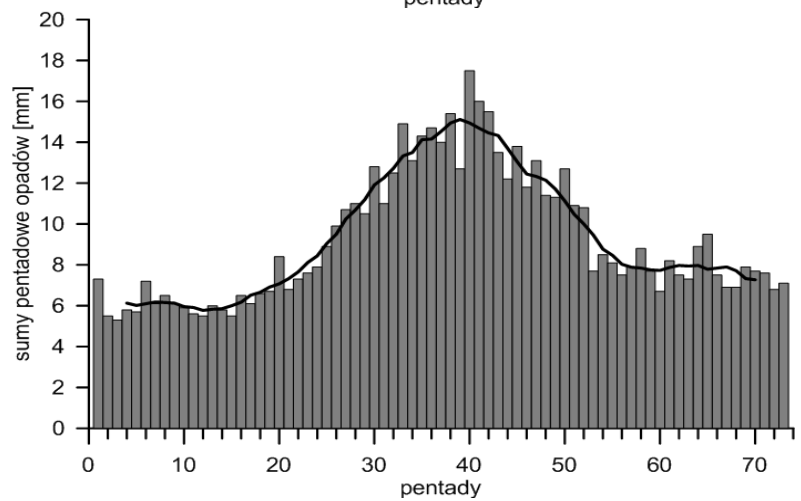

c)

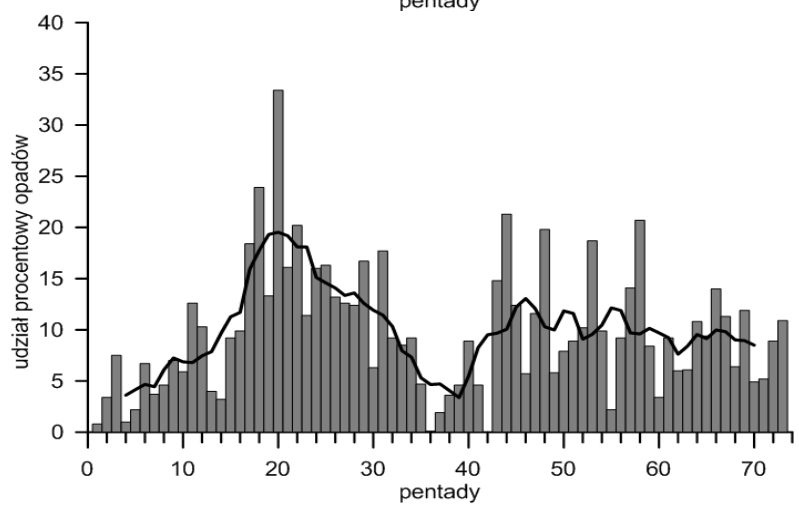

Rys. 5.7. Średnie pentadowe sumy opadów $M C P$ (a) i całkowite sumy opadów na obszarze Polski (b) oraz udział MCP w całkowitej sumie opadów (c). Dodano średnią ruchomą 7-elementową (wg Degirmendžića i Kożuchowskiego, 2015a)

Roczny rytm „opadów śródziemnomorskich” różni się zasadniczo od przebiegu całkowitych sum opadów w Polsce. Opisana depresja lipcowa MCP przypada na porę najwyższych opadów w Polsce. Wysokie opady $M C P$ w okresie wiosennym przypadają na porę małych całkowitych sum opadu w tym 
sezonie; opady MCP mają w związku z tym swój znaczny udział w kształtowaniu warunków pluwialnych na wiosnę. Bez opadów śródziemnomorskich wiosna w Polsce byłaby zapewne znacznie bardziej sucha.

\section{Wnioski}

Opady związane $\mathrm{z}$ działalnością niżów śródziemnomorskich MEC, przemieszczających się nad Europę Środkowo-Wschodnią, stanowią średnio około $10 \%$ całkowitej wysokości opadów atmosferycznych występujących w Polsce. Udział ten nie jest mały, zważywszy, że częstość MEC i związanych z nimi opadów jest bardzo niska. W skrajnych przypadkach sumy miesięczne opadów śródziemnomorskich są bliskie lub nieco wyższe od średnich całkowitych sum opadów w Polsce. Niektóre absolutne maksima sum dobowych opadów mają także genezę śródziemnomorską.

Opady związane z niżami $M E C$ należą do najintensywniejszych w Polsce. Udział MCP w całkowitych sumach opadowych wzrasta wraz $\mathrm{z}$ wysokością tych sum. Opady dobowe o wysokości $>80 \mathrm{~mm}$ składają się średnio prawie $\mathrm{w}^{1 / 4} \mathrm{z}$ opadów MCP.

Opady o genezie śródziemnomorskiej wyróżniają się względnie dużą obfitością. Średnia obfitość opadów śródziemnomorskich (wysokość opadu MCP/dzień z opadem) stanowi około 150\% średniej obfitości wszystkich opadów w Polsce.

Wysokość opadów MCP oraz ich udział w całkowitych sumach opadów zmieniają się sezonowo, osiągając maksima w końcu kwietnia oraz w połowie sierpnia. W kwietniu (6-10.04) opady śródziemnomorskie stanowią blisko $1 / 3$ całkowitych sum opadów w Polsce. Charakterystyczną cechą rocznego przebiegu $M C P$ jest depresja, przypadająca na okres od końca czerwca do końca lipca, która rozdziela dwie fazy nasilonych opadów MCP - pierwszą, wiosenną i drugą, trwająca od końca lata do jesieni.

Degirmendžić J., Kożuchowski K., 2015a, Precipitation of the Mediterranean origin in Poland - its seasonal and long-term variability. Quaestiones Geographicae, vol. 34, z. 1, Bogucki Wydawnictwo Naukowe, Poznań, s. $37-52$ 



\section{Rozdział 6 \\ Szlaki niżów śródziemnomorskich \\ a rozkład opadów $M C P$ na obszarze Polski}

\section{Położenie niżów a opady}

Najwyższe opady o genezie śródziemnomorskiej pojawiają się w strefach, objętych północną, północno-wschodnią bądź wschodnią cyrkulacją cyklonalną, czyli w układach bliskich typowi cyrkulacji cyklonalnej wschodniej i północno-wschodniej Eo (wg klasyfikacji Osuchowskiej-Klein, 1978). Typ ten, według wielu autorów przynosi wysokie opady zarówno w Polsce PółnocnoZachodniej (Świątek, 2008; Kirschenstein, 2013), jak i w Polsce Środkowej (Wibig i Fortuniak, 1998) oraz na południu kraju (Dubicka, 1991; Twardosz, 1997).

Spostrzeżenia te pozostają w zgodzie z wnioskami Świątek (2013b), która stwierdziła, że najwyższe opady w Polsce Północnej związane są z niżami położonymi na wschód lub północny-wschód od miejsc ich wystąpienia. Także Sobik i Błaś (2010) oraz Wrona (2008) zauważyli, że wysokie sumy opadowe na Dolnym Śląsku wiążą się z niżami, ulokowanymi na wschód lub południowy wschód od tego regionu.

Sobik i Błaś (2010) przedstawili uproszczony model układu cyrkulacyjnego, prowadzący do „makroskalowej konwergencji” i rozlewnych opadów w niżach śródziemnomorskich („Vb”). Układ ten składa się ze strumienia zimnego powietrza napływającego z północy (a więc po zachodniej stronie niżu) oraz strumienia powietrza ciepłego i wilgotnego, napływającego z północnego wschodu i wznoszącego się po powierzchni frontalnej, ponad masą powietrza zimnego. Opady MCP mają zatem charakter frontalny, podobnie jak większość (ponad 2/3) ekstremalnych opadów w Polsce (Łupikasza, 2010a). Czynnik orograficzny niewątpliwie wpływa na wzrost intensywności tych opadów 
w górach i na ich przedpolu wskutek kierunku adwekcji, prostopadłego do układu pasm górskich.

Największe prawdopodobieństwo wysokich opadów związanych z aktywnością niżów Vb obejmuje obszar Polski ciągnący się od Beskidu Śląskiego i Żywieckiego przez wyżyny aż do Bugu na odcinku Terespol-Włodawa (Projekt KLIMAT, 2010). Jak widać, jest to obszar leżący po zachodniej stronie szlaku niżowego Vb w „klasycznym ujęciu” van Bebbera (1891).

Mudelsee i in. (2004) zwracają ponadto uwagę na chwiejność atmosfery, generującą powstawanie bądź nasilanie się opadów w układach cyklonalnych. Termiczne warunki kształtowania się chwiejnej równowagi powietrza występują przede wszystkim w strefie adwekcji chłodu, czyli po zachodniej stronie niżów.

Celem niniejszej części opracowania jest określenie związków między położeniem niżów śródziemnomorskich na ich szlakach przebiegających przez Europę i wysokością opadów atmosferycznych na obszarze Polski. Wyniki badań mają pokazać, w jakim stopniu szlak niżów wpływa na wysokość opadów w Polsce i jak kształtuje się pole opadów pochodzenia śródziemnomorskiego $w$ Polsce $w$ relacji do toru niżów MEC. Sprawdzona zostanie hipoteza, że poszczególnym torom niżów odpowiadają odmienne wysokości oraz rozmieszczenie opadów śródziemnomorskich na obszarze Polski, a w szczególności - że najwyższe opady lokują się na zachód od MEC.

W analizie związków opadów z położeniem niżów uwzględniono cztery klasy $M E C$ :

E - wschodnia klasa niżów, których szlak wędrówki przebiega na wschód od

Polski i zarazem jest najbardziej zbliżony do szlaku Vb van Bebbera;

C - centralna klasa niżów ze szlakami przechodzącymi przez obszar Polski;

W - zachodnia klasa niżów, przemieszczających się szlakiem położonym na zachód od Polski;

S - południowa klasa niżów, wędrujących z zachodu na wschód szlakiem położonym na południe od Polski.

Wykorzystano opadotwórcze odcinki trajektorii niżów, czyli takie, z którymi związane są najwyższe opady w Polsce.

Pola opadów w Polsce związane z daną trajektorią MEC przedstawiono jako rozkłady przestrzenne sum dobowych uśrednione z terminów, w których niże $M E C$ znajdowały się $\mathrm{w}$ pobliżu opadotwórczego odcinka trajektorii (szczegółowy opis procedury w rozdz. 3.) 
Sumy opadów dobowych związanych z określonymi szlakami niżów porównano ze średnimi sumami opadów $\mathrm{w}$ dniach $\mathrm{z}$ opadem (tzn. $\mathrm{z}$ obfitością opadów) w poszczególnych stacjach na obszarze Polski. Wyznaczono wskaźniki efektywności opadów, związanych z niżami śródziemnomorskimi, zdefiniowane jako ilorazy średniej dobowej sumy opadów MCP i średniej obfitości opadów całkowitych w danym miejscu.

\section{Wschodni szlak niżów MEC}

Wschodni szlak niżowy (E) rozpoczyna się nad Balearami, następnie przebiega na północny-wschód nad Korsykę, przekracza Półwysep Apeniński oraz północny Adriatyk (rys. 6.1). Na dalszym etapie wędrówki niże śródziemnomorskie kierują się nad Słowenię i Węgry. Odcinek nad Węgrami ma charakter równoleżnikowy, co wiąże się to prawdopodobnie z orografią Karpat. Nad północno-zachodnią Rumunią niże klasy E zmieniają kierunek na północnowschodni i przedostają się nad zachodnią Ukrainę przez przewężenie Karpat między Bieszczadami a Gorganami. Następnie układy niżowe przemieszczają się na północ przez Białoruś i kraje nadbałtyckie. Trajektoria E kończy się nad południową Finlandią. Spośród 351 zidentyfikowanych niżów śródziemnomorskich $22,8 \%$ przemieszczało się szlakiem E.

Opadotwórczy odcinek szlaku wschodniego niżów śródziemnomorskich (E) obejmuje środkowy fragment tego szlaku, położony między północnym Adriatykiem i zachodnią Ukrainą. Dalsze przemieszczanie się tych niżów na północ wiąże się z wyraźnym osłabieniem opadów na obszarze Polski (rys. 6.2).

Średnie sumy opadów dobowych, związanych z opadotwórczym odcinkiem szlaku niżowego E, osiągają wysokość około $15 \mathrm{~mm}$ wysoko w Tatrach i w Beskidzie Śląskim (Bielsko Biała), a w Zakopanem, w Żywcu, w Dobczycach oraz na Śnieżce wynoszą 10-11 mm. Dość wysokie (>6 mm) średnie wartości obejmują całą południowo-wschodnią połowę kraju, na północnym zachodzie natomiast średnie te szybko zmniejszają się do zaledwie $1 \mathrm{~mm}$ w Świnoujściu (rys. 6.3). Średnia krajowa wysokość opadów śródziemnomorskich związana z opadotwórczym odcinkiem szlaku E jest najwyższa i wynosi $5,9 \mathrm{~mm}$ (tab. 6.1). Jest to wysokość, stanowiąca 154\% średniej obfitości opadów w Polsce (3,82 mm/dzień). 


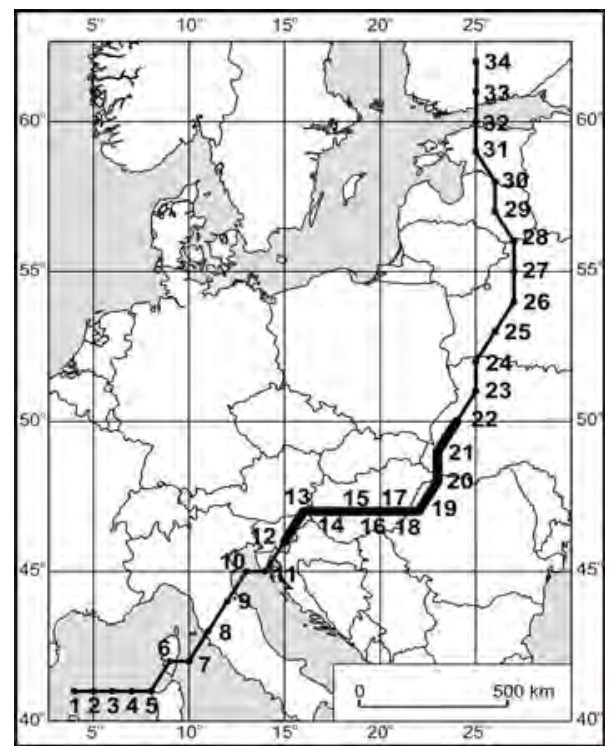

Rys. 6.1. Średnie położenie szlaku wschodniego (E) niżów śródziemnomorskich. Punkty trajektorii ponumerowano zgodnie z kierunkiem ruchu niżów. Linią pogrubioną oznaczono opadotwórczy odcinek trajektorii (wg Degirmendžića i Kożuchowskiego, 2015c)

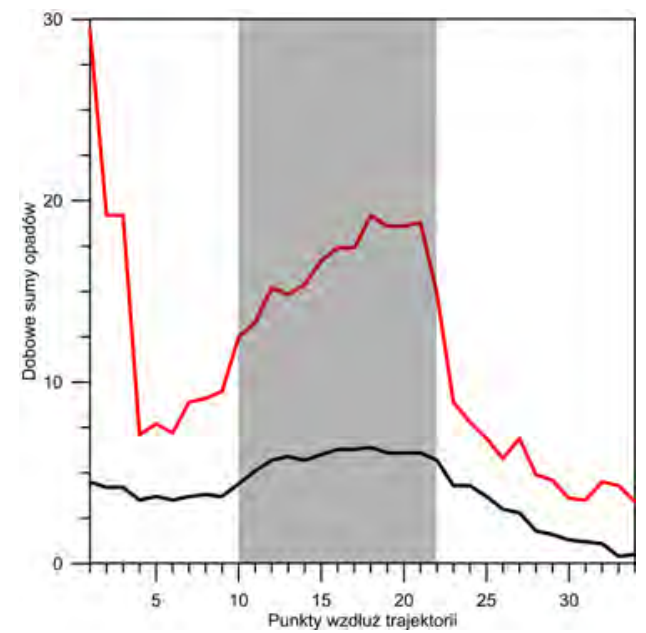

Rys. 6.2. Średnie dobowe wysokości opadów $M C P$ [mm] w Polsce w zależności od położenia ośrodków niżów $M E C$ na szlaku wschodnim. Linia czerwona oznacza najwyższe średnie dobowe w Polsce, linia czarna - średnie obszarowe sumy opadów na obszarze Polski. Pole zaciemnione odpowiada opadotwórczemu odcinkowi szlaku (wg Degirmendžića i Kożuchowskiego, 2015c) 


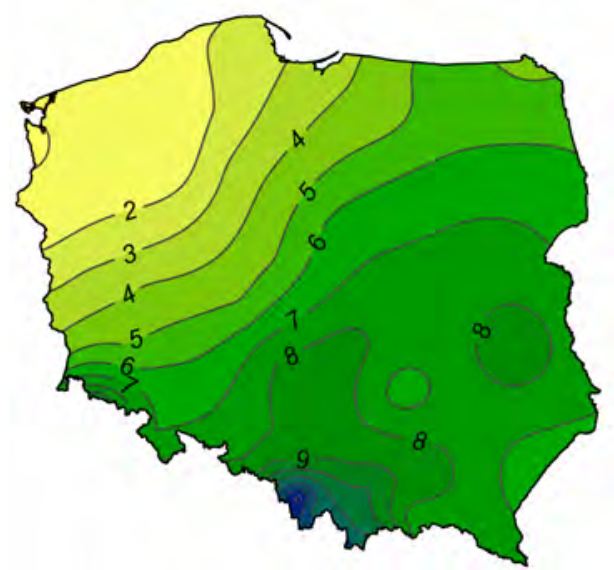

Rys. 6.3. Średnie dobowe sumy $M C P$ [mm] na obszarze Polski, odpowiadające położeniu niżów $M E C$ na opadotwórczym odcinku szlaku wschodniego (wg Degirmendžića i Kożuchowskiego, 2015c)

\section{Centralny szlak niżów MEC}

Centralny szlak niżów (C) zaczyna się nad Półwyspem Iberyjskim. Jego przebieg przez akwen Morza Śródziemnego jest zbliżony do szlaku E. Niże po wejściu na ląd kierują się bardziej na północ w porównaniu ze szlakiem E - przez Austrię i Czechy. Kierunek przemieszczania niżów na północnywschód jest zachowany aż do granicy Polski. Następnie trajektoria C dzieli się i niże przemieszczają się szlakiem zachodnim (CW), usytuowanym nad zachodnią Polską, Szwecją i Norwegią lub wschodnim (CE), który przebiega nad wschodnią częścią Polski i przez Litwę, Łotwę, Estonię i Finlandię dociera aż w okolice Morza Białego (rys. 6.4). Na szlaku C zarejestrowano ogółem 34,2\% układów MEC.

W przypadku niżów przechodzących centralnie przez Polskę (C) opadotwórczy odcinek ich szlaku ciągnie się od Zatoki Genueńskiej i sięga do terenów południowo-zachodniej (gałąź CW) lub północno-wschodniej Polski (gałąź CE). Wyraźnie zaznaczone maksimum opadów w Polsce odpowiada położeniu ośrodka niżowego nad północną Austrią (rys. 6.5).

Średnie wysokości opadów związanych ze szlakami CW i CE zmieniają się od 16-17 mm na Śnieżce do 3-4 mm na wschodzie kraju i na Wybrzeżu (rys. 6.6). Średnie wartości dobowych opadów $M C P$ na całym obszarze wynoszą 5,5 mm (CW) i 5,6 mm (CE), stanowiąc 143 i 147\% średniej obfitości całkowitych opadów w Polsce (tab. 6.1). 


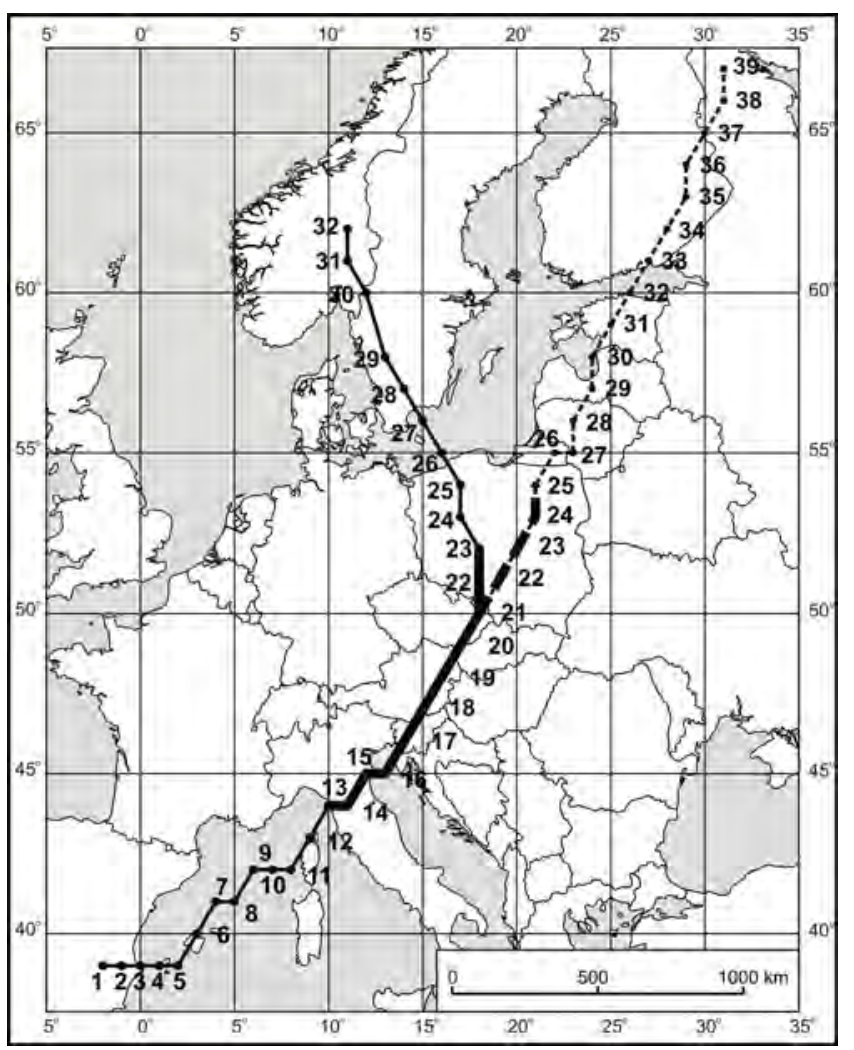

Rys. 6.4. Średnie położenie szlaku centralnego $(\mathrm{C})$ niżów śródziemnomorskich $\mathrm{z}$ gałęzią wschodnią (CE) i zachodnią (CW). Oznaczenia jak na rys. 6.1 (wg Degirmendžića i Kożuchowskiego, 2015c)

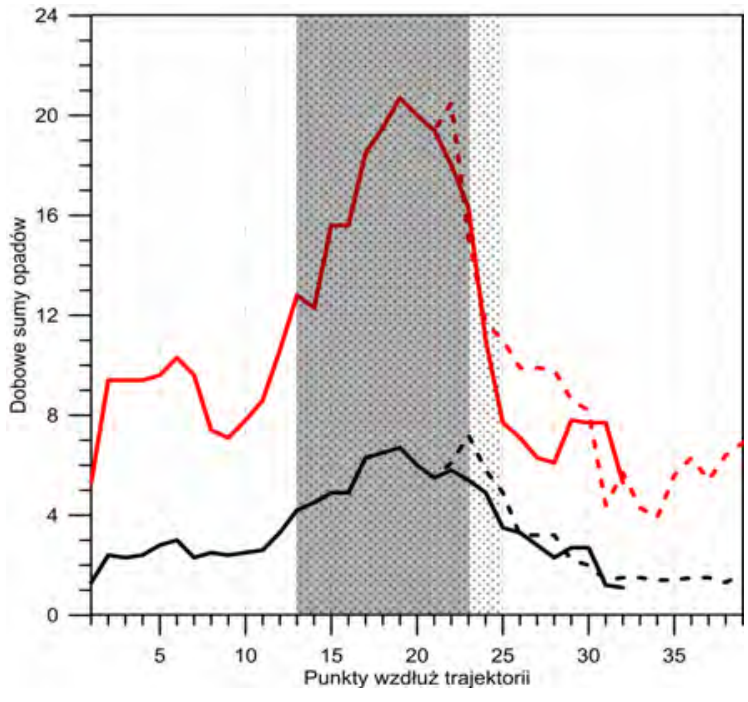

Rys. 6.5. Średnie dobowe wysokości opadów MCP [mm] w Polsce $\mathrm{w}$ zależności od położenia ośrodków niżów $M E C$ na szlaku centralnym. Linia czerwona oznacza najwyższe średnie dobowe w Polsce, linia czarna - średnie obszarowe sumy opadów na obszarze Polski (linie przerywane - odpowiednio opady związane z położeniem niżów na wschodniej gałęzi szlaku). Pole zaciemnione odpowiada opadotwórczemu odcinkowi szlaku centralnego, szraf dotyczy opadotwórczego odcinka wschodniej gałęzi szlaku (wg Degirmendžića i Kożuchowskiego, 2015c) 

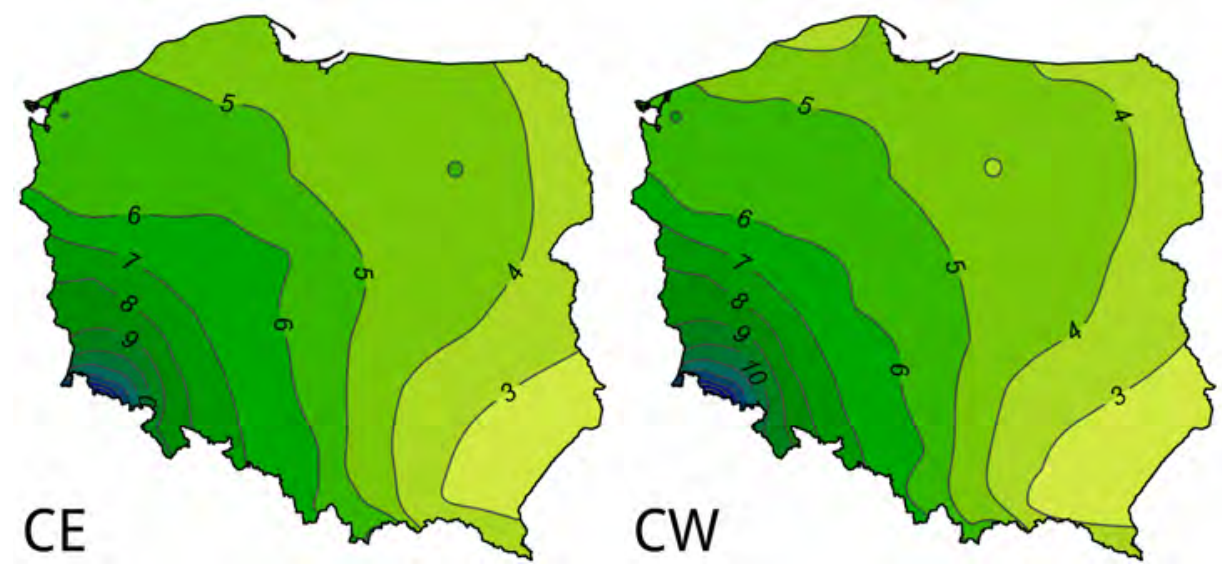

Rys. 6.6. Średnie dobowe sumy opadów $M C P[\mathrm{~mm}]$ na obszarze Polski, odpowiadające położeniu niżów $M E C$ na opadotwórczych odcinkach szlaku centralnego - CE (lewa mapa) i CW (prawa mapa) (wg Degirmendžića i Kożuchowskiego, 2015c)

\section{Zachodni szlak niżów MEC}

Szlak niżów, zaliczonych do klasy zachodniej (W) jest usytuowany bardzo podobnie do szlaku C w granicach basenu Morza Śródziemnego. Jednak centra niżów przemieszczających się tym szlakiem nie pojawiają się nad Adriatykiem. Znad Półwyspu Apenińskiego kierują się prosto na północ, nad Niemcy. Nad centralną częścią Niemiec trajektoria dzieli się na dwie odnogi - zachodnią (WW), która kieruje się nad Morze Północne oraz wschodnią (WE), która kończy się nad zachodnim Bałtykiem (rys. 6.7). Tor W jest wyraźnie krótszy w porównaniu z pozostałymi typami torów MEC. Niewielka jest także częstość występowania niżów na tym szlaku - wynosi 7,7\%.

Opadotwórczy odcinek na zachodnim szlaku niżów obejmuje większą część tego szlaku od Morza Liguryjskiego aż do Morza Północnego (szlak WW) i do Bałtyku (szlak WE). W przeciwieństwie do innych szlaków, opady śródziemnomorskie w Polsce wzrastają w miarę przesuwania się niżów klasy W ku północy, osiągając maksima przy położeniu ośrodków niżowych nad Morzem Północnym i Bałtykiem (rys. 6.8). Maksima te nie są jednak tak wysokie, jak w przypadku niżów, przemieszczających się pozostałymi szlakami.

Opady dobowe, związane ze szlakiem zachodnim niżów śródziemnomorskich (W) nie są w Polsce wysokie i osiągają zaledwie połowę średniej obfitości opadów atmosferycznych (tab. 6.1). Jedynie w Tatrach średnie sumy 
opadowe są bliskie lub nieco wyższe od średniej obfitości opadów w tym regionie (7-8 mm/dzień).

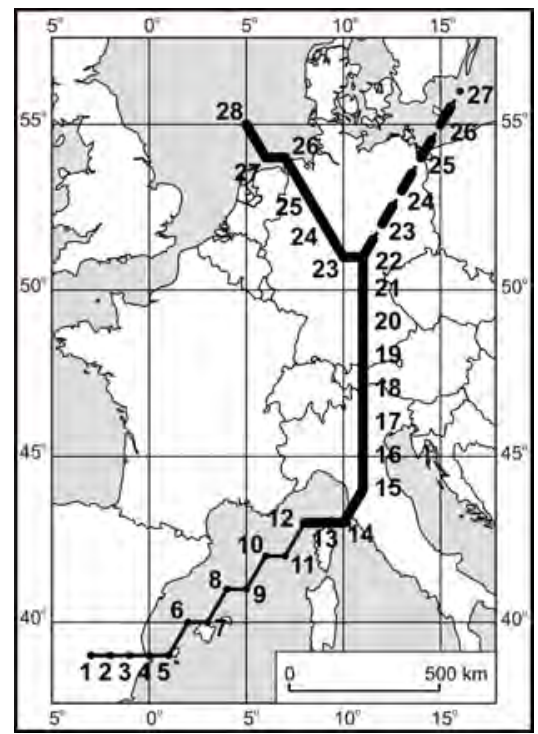

Rys. 6.7. Średnie położenie szlaku zachodniego (W) niżów śródziemnomorskich z gałęzią wschodnią (WE) i zachodnią (WW). Oznaczenia jak na rys. 6.1

(wg Degirmendžića i Kożuchowskiego, 2015c)

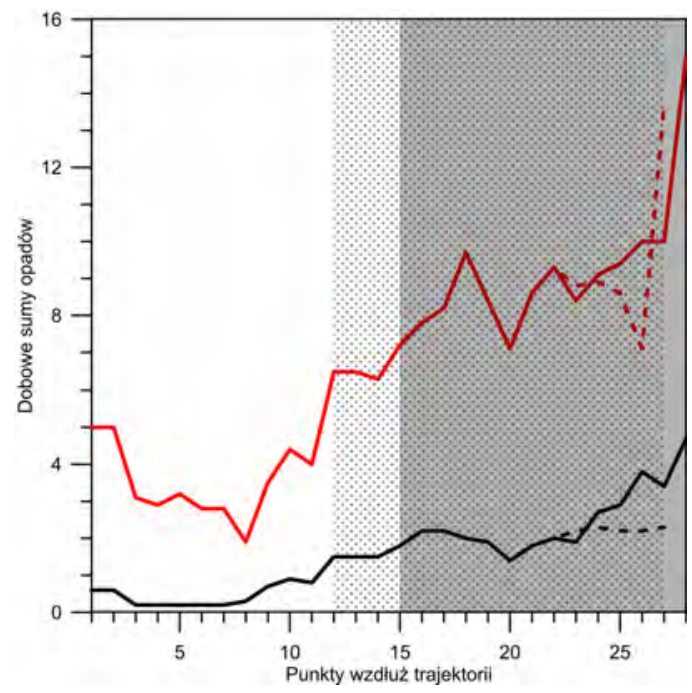

Rys. 6.8. Średnie dobowe wysokości opadów $M C P$ [mm] w Polsce w zależności od położenia ośrodków niżów $M E C$ na szlaku zachodnim. Oznaczenia jak na rys. 6.5 (wg Degirmendžića i Kożuchowskiego, 2015c) 
W pasie od Karpat aż do Pomorza średnie opady dobowe, związane z niżami MEC na szlaku zachodnim osiągają miejscami 3-4 mm, na wschodzie kraju zmniejszają się do wartości poniżej 1 mm (rys. 6.9).
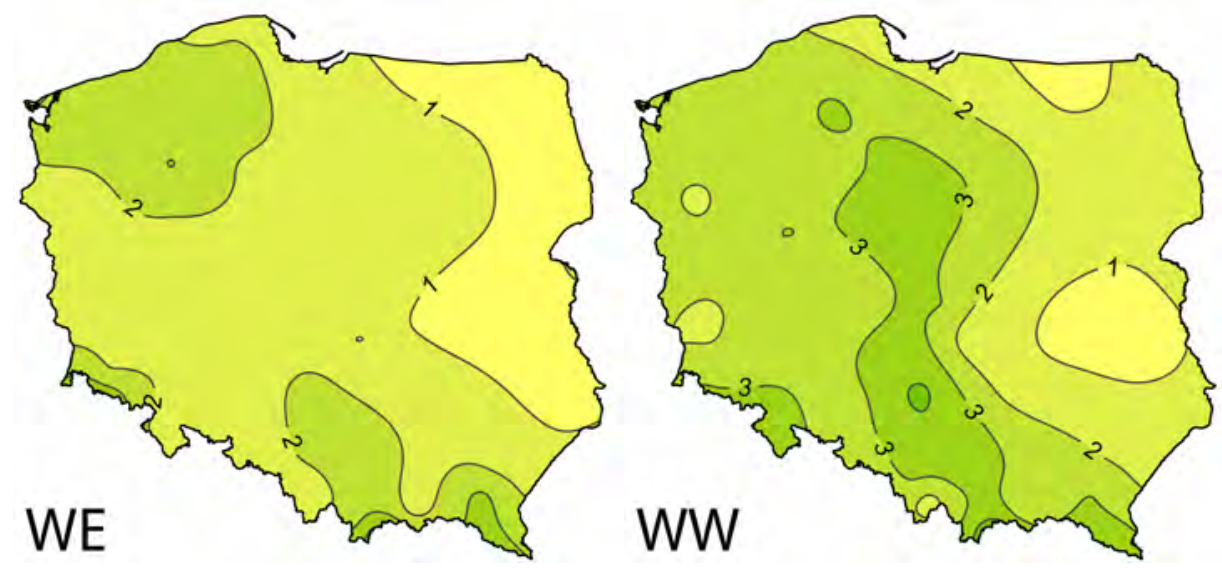

Rys. 6.9. Średnie dobowe sumy opadów $M C P[\mathrm{~mm}]$ na obszarze Polski, odpowiadające położeniu niżów $M E C$ na opadotwórczych odcinkach szlaku zachodniego - WE (lewa mapa) i WW (prawa mapa) (wg Degirmendžića i Kożuchowskiego, 2015c)

\section{Południowy szlak niżów MEC}

Położenie szlaku południowego (S) nad basenem Morza Śródziemnego nie różni się istotnie od położenia pozostałych torów. Układy niżowe tej klasy, po przejściu przez Adriatyk, przemieszczają się równoleżnikowo na wschód przez Węgry i Rumunię, a dopiero nad Ukrainą wędrują na północny wschód (rys. 6.10). Szlakiem S przemieszcza się 25,9\% niżów MEC.

Najwyższe maksymalne opady wiążą się ze szlakiem południowym niżów przy ich położeniu na odcinku ciągnącym się przez Węgry i Rumunię. Opady szybko maleją, gdy szlak niżowy S zwraca się ku północy w swym końcowym odcinku (rys. 6.11).

Wysokie opady związane ze szlakiem południowym niżów śródziemnomorskich (S) występują jedynie w południowej Polsce, zwłaszcza w Tatrach. Na Kasprowym Wierchu średnie sumy dobowe osiągają $16 \mathrm{~mm}$, na Hali Gąsienicowej prawie $18 \mathrm{~mm}$ (odpowiednio 206 i 231\% obfitości opadów całkowitych). Średnia suma krajowa nie jest jednak wielka (3,3 mm tj. 87\% średniej obfitości całkowitych opadów), gdyż w całej północnej połowie kraju sumy dobowe MCP kształtują się na poziomie zaledwie 1-2 mm (rys. 6.12). 


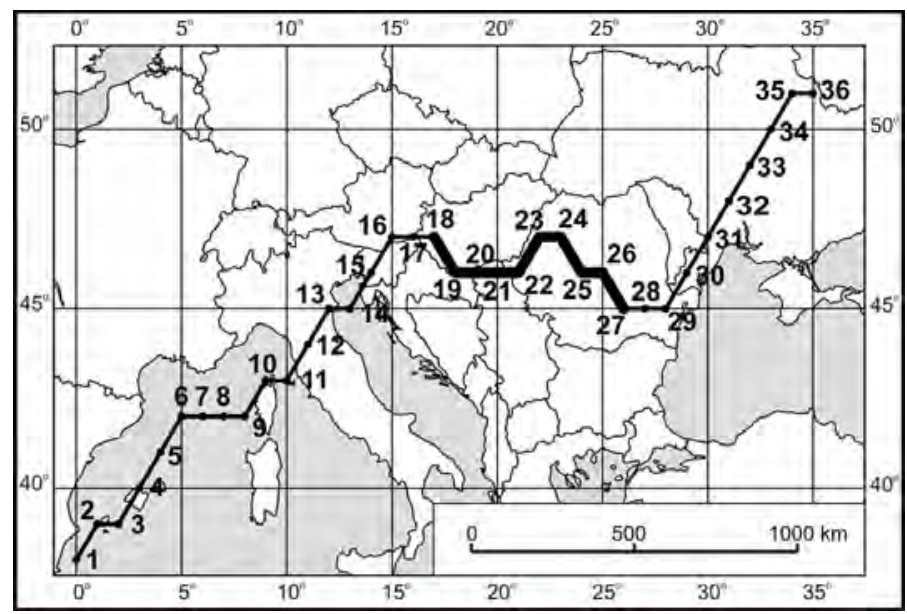

Rys. 6.10. Średnie położenie szlaku południowego (S) niżów śródziemnomorskich. Oznaczenia jak na rys. 6.1 (wg Degirmendžića i Kożuchowskiego, 2015c)

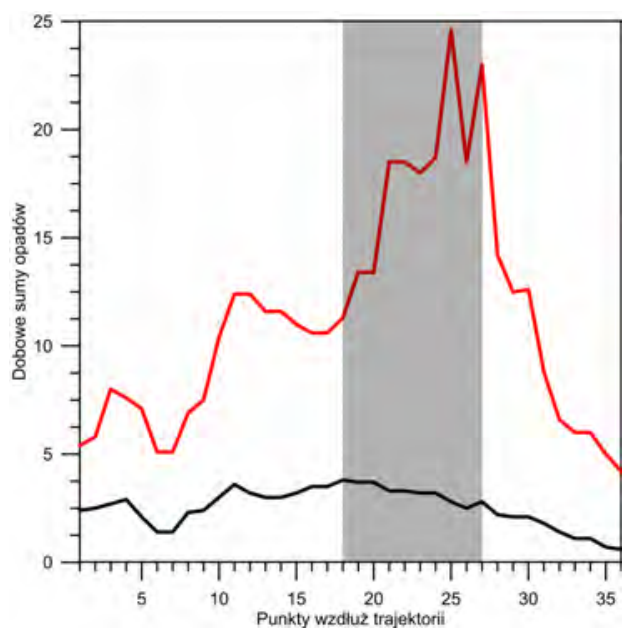

Rys. 6.11. Średnie dobowe wysokości opadów $M C P$ [mm] w Polsce w zależności od położenia ośrodków niżów $M E C$ na szlaku południowym. Oznaczenia jak na rys. 6.2 (wg Degirmendžića i Kożuchowskiego, 2015c) 


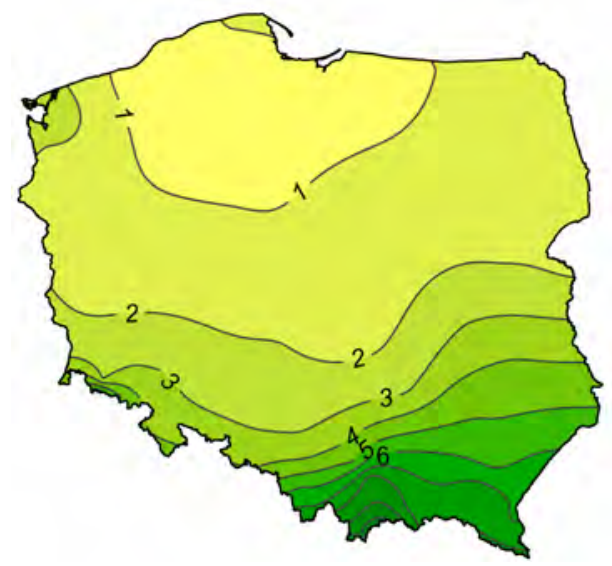

Rys. 6.12. Średnie dobowe sumy opadów $M C P[\mathrm{~mm}]$ na obszarze Polski, odpowiadające położeniu niżów $M E C$ na opadotwórczym odcinku szlaku południowego (wg Degirmendžića i Kożuchowskiego, 2015c)

\section{Maksima średnich opadów MCP}

Opady MCP przewyższające średnią obfitość opadu całkowitego w określonych stacjach na terenie Polski wiążą się z czterema szlakami niżów: CW, CE, E lub S. Obliczone wskaźniki efektywności opadów $M C P$ związanych ze szlakami, przynoszącymi najwyższe opady w poszczególnych stacjach meteorologicznych przekraczają wszędzie $100 \%$, co świadczy o tym, że $M C P$ w całej Polsce odznaczają się podwyższoną obfitością. Najwyższe wskaźniki (największa efektywność opadów $M C P$ ) występują w Sudetach i na Dolnym Śląsku (Śnieżka 328\%, Jelenia Góra 327\%, Legnica 290\%, Zgorzelec 279\%). Dość wysokie są wskaźniki efektywności w zachodniej części Karpat i Pogórza oraz na Wyżynach (Bielsko 267\%, Lublin 263\%, Hala Gąsienicowa 231\%, Dobczyce 239\%, Kraków 237\%, Częstochowa 230\%, Tarnów 220\%, Racibórz 217\%, Kasprowy Wierch 207\%, Zakopane 206\%, Katowice 203\%). Najniższe wartości są charakterystyczne dla Wybrzeża (Ustka 108\%, Łeba 111\%).

Na mapie wskaźnika Ie (rys. 6.13) można wyróżnić południową połowę kraju, w której $M C P$ dwu- a nawet trzykrotnie przekraczają średnią obfitość całkowitych opadów, oraz pozostałą część północną, z sumami $M C P$ w granicach 100-200\% średniej obfitości opadów. Za charakterystyczne trzeba uznać trzy strefy względnie wysokich opadów śródziemnomorskich, obejmujące Dolny Śląsk, Małopolskę i Lubelszczyznę, którym odpowiadają wskaźniki 
Ie $>220 \%$ (rys. 6.13). Zwraca uwagę w szczególności region dolnośląski, w którym opady MCP charakteryzują się największą efektywnością.

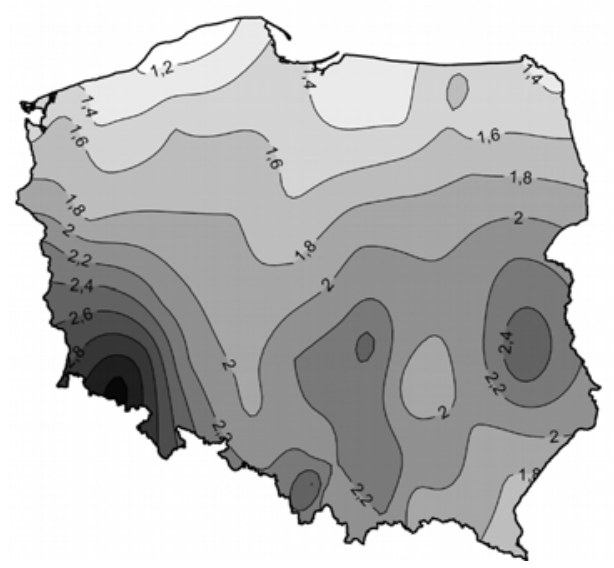

Rys. 6.13. Wskaźnik efektywności najwyższych średnich opadów MCP w Polsce

(wg Degirmendžića i Kożuchowskiego, 2015c)

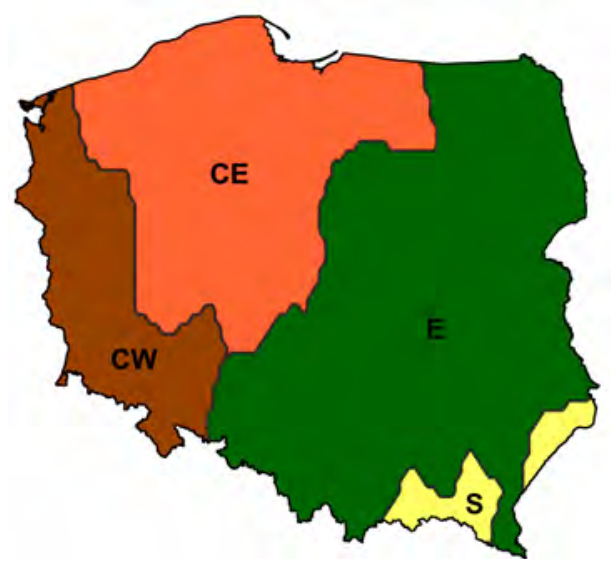

Rys. 6.14. Zasięgi występowania najwyższych średnich dobowych opadów MCP w Polsce, odpowiadających szlakom E, CE, CW i S (wg Degirmendžića i Kożuchowskiego, 2015c)

Najwyższe $M C P$ w zachodniej Polsce związane są ze szlakiem niżowym CW, w północnej i środkowo-zachodniej Polsce - ze szlakiem CE, na krańcach południowo-wschodnich maksima opadowe wiążą się ze szlakiem S, w pozostałej, największej obszarowo części kraju, najwyższe sumy $M C P$ przynoszą niże wędrujące szlakiem E. Obszar dominacji opadów, związanych z tym szlakiem ogranicza od zachodu linia biegnąca od Opola do Kętrzyna. Na zachód 
od tej linii opady o najwyższych sumach dobowych wiążą się z oddziaływaniem niżów ze szlaku centralnego (C), przy czym na obszarze położonym na zachód od Opola, Poznania i Kołobrzegu są to niże wędrujące szlakiem CW (rys. 6.14).

Warto zauważyć, że wykreślone granice zasięgu oddziaływania poszczególnych szlaków niżowych (E, CE i CW) niemal dokładnie odpowiadają przebiegowi szlaku centralnego $C$ wraz $z$ jego gałęziami $C W$ i CE (por. rys. 6.14 i rys. 6.4). Najwyższe opady $M C P$ występują po lewej (zachodniej) stronie tych szlaków. Obszar objęty oddziaływaniem niżów ze szlaku E (południowo-wschodnia połowa kraju) znajduje się także po lewej, zachodniej stronie szlaku E. Podobnie ma się rzecz z zaznaczonymi fragmentami południowo-wschodnich regionów, pozostających w zasięgu oddziaływań niżów, przemieszczających się szlakiem S - maksymalne opady notowane są po lewej (północnej) stronie szlaku.

Średnie wysokości sum dobowych $M C P$ w regionach opadowych, przyporządkowanych poszczególnym szlakom niżowym według kryterium opadu najwyższego, wahają się od 5 do $10 \mathrm{~mm}$, a wskaźniki efektywności od 150 do $241 \%$ (tab. 6.1).

Tab. 6.1. Średnie dobowe wysokości opadów śródziemnomorskich (mm) i wskaźniki ich efektywności (\%) w zależności od klasy szlaku niżów śródziemnomorskich

(wg Degirmendžića i Kożuchowskiego, 2015c)

\begin{tabular}{lrrrrrr}
\hline Charakterystyki & \multicolumn{7}{c}{ Klasa szlaków MEC } \\
& WW & WE & CW & CE & E & S \\
\hline $\begin{array}{l}\text { Średnie krajowe opadów MCP } \\
\quad \text { Wysokość opadu } \\
\quad \text { Efektywność }\end{array}$ & 2,49 & 1,97 & 5,48 & 5,60 & 5,89 & 3,33 \\
\hline $\begin{array}{l}\text { Najwyższe średnie opadów MCP* } \\
\quad \text { Wysokość opadu }\end{array}$ & 65 & 52 & 143 & 147 & 154 & 87 \\
$\quad$ Efektywność & - & - & 8,68 & 5,20 & 7,90 & 10,06 \\
\hline $\begin{array}{l}\text { Ponadprzeciętne opady MCP** } \\
\quad \text { Wysokość opadu } \\
\text { Efektywność }\end{array}$ & - & - & 241 & 150 & 206 & 200 \\
\hline
\end{tabular}

* - średnie dobowe sumy MCP na obszarach wg rys. 6.14

** - średnie dobowe sumy MCP na obszarach wg rys. 6.15 W nawiasach wartości dotyczace 1-3 stacji meteorologicznych. 


\section{Efektywne opady MCP}

Ponadprzeciętną wysokością (tzn. wskaźnikiem Ie>100\%), podobnie jak najwyższe średnie opady $M C P$, charakteryzują się w Polsce opady związane przede wszystkim ze szlakami CW, CE, E i S (zanotowano jedynie kilka przypadków, w których takiej wysokości opad wiązał się z zachodnim typem szlaków niżowych). Zasięgi występowania $M C P$ wyższych od średniej obfitości opadów całkowitych („opadów efektywnych” $M C P$ ) nakładają się, ale warto podkreślić, że w całym kraju te ponadprzeciętne opady dobowe związane są $\mathrm{z}$ dwoma, trzema, a miejscami nawet z czterema szlakami niżów $M E C$.
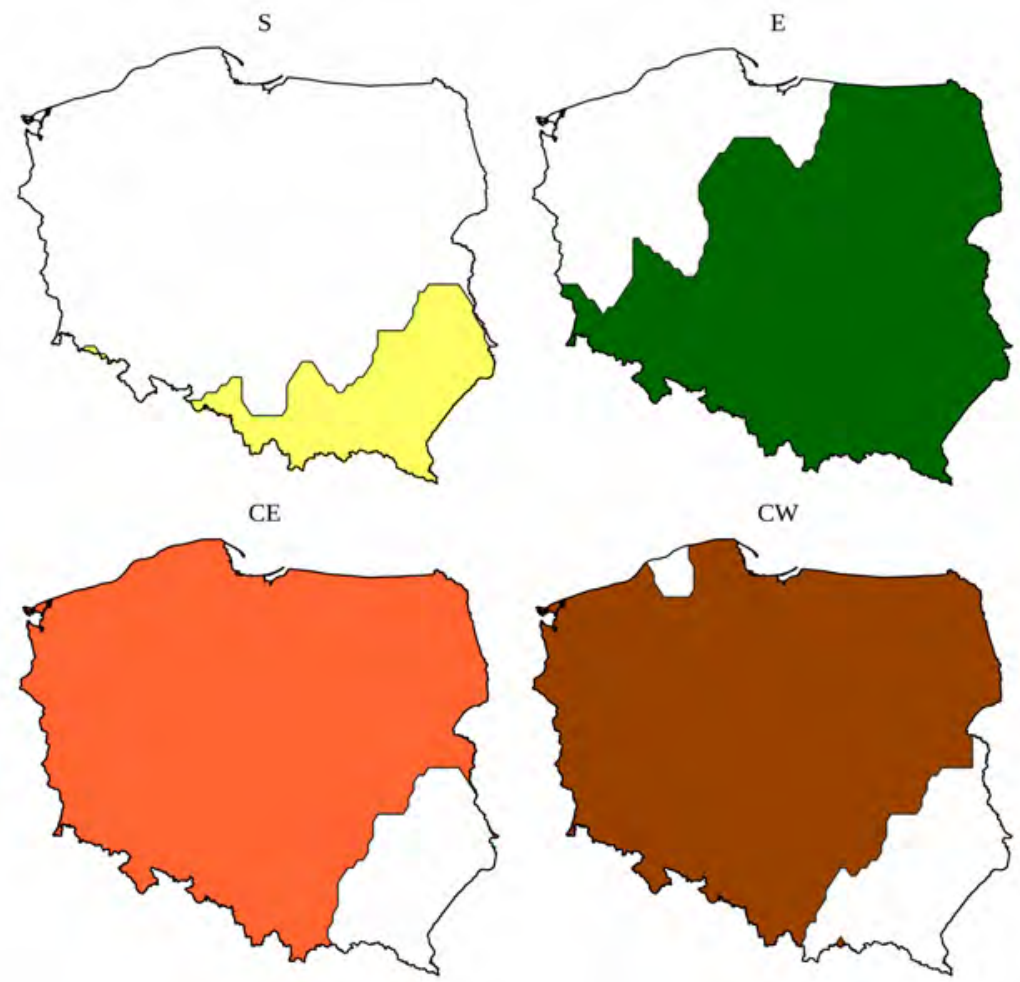

Rys. 6.15. Zasięgi występowania efektywnych opadów $M C P$ (Ie>100\%) na obszarze Polski, związanych z położeniem $M E C$ na szlaku południowym (S), wschodnim (E), oraz centralnym (CE i CW) (wg Degirmendžića i Kożuchowskiego, 2015c)

Największy zasięg występowania $M C P$ o wysokości większej od średniej obfitości opadów wiąże się z centralnym położeniem szlaków niżowych, tj. ze szlakami typu CW i CE. Nie obejmuje on jedynie Polski Południowo-Wschod- 
niej. W tym bowiem regionie do ponadprzeciętnych opadów MCP przyczyniają się niże wędrujące szlakiem południowym (S). Niże ze szlaku wschodniego (E) powodują natomiast ponadprzeciętne opady w przeważającej, południowo wschodniej części Polski - aż po linię przechodzącą przez okolice Poznania, Bydgoszczy i Olsztyna (rys. 6.15). Średnie dobowe wysokości opadów MCP w regionach występowania ponadprzeciętnych opadów, związanych z oddziaływaniem niżów CW, CE, E i S wahają się w granicach 6-8 mm, a wskaźniki efektywności od 158 do 187\% (tab. 6.1).

Tab. 6.2. Średnia obfitość całkowitych opadów atmosferycznych w wybranych stacjach [mm/dzień], średnie dobowe sumy opadów śródziemnomorskich w zależności od typu szlaku niżów śródziemnomorskich oraz wskaźnikowe typy szlaków związanych z najwyższą $\left(M C P_{\text {MAX }}\right)$ oraz z wyższą od średniej (Ie>100\%) obfitością opadów śródziemnomorskich (wg Degirmendžića i Kożuchowskiego, 2015c)

\begin{tabular}{|c|c|c|c|c|c|c|c|c|c|}
\hline \multirow{2}{*}{ Stacje } & \multirow{2}{*}{$\begin{array}{c}\text { Obfitość } \\
\text { opadu } \\
\text { całkowi- } \\
\text { tego }\end{array}$} & \multicolumn{6}{|c|}{$\begin{array}{l}\text { Obfitość opadu MCP związana } \\
\text { z danym typem szlaku MEC }\end{array}$} & \multicolumn{2}{|c|}{ Wskaźnikowe typy szlaków } \\
\hline & & WW & WE & CW & CE & $\mathbf{E}$ & $\mathbf{S}$ & $M C P_{\text {MAX }}$ & le $>100 \%$ \\
\hline Świnoujście & 3,3 & 1,8 & 1,4 & 4,4 & 4,4 & 0,7 & 2,4 & CW & CW CE \\
\hline Śnieżka & 5,2 & 4,0 & 4,8 & 17,1 & 16,3 & 10,5 & 7,5 & CW & CW CE E S \\
\hline Poznań & 3,2 & 3,0 & 1,7 & 6,0 & 6,2 & 3,0 & 1,3 & $\mathrm{CE}$ & CW CE \\
\hline Łódź & 3,4 & 3,1 & 1,8 & 5,3 & 5,5 & 7,1 & 1,2 & $E$ & CW CE E \\
\hline Lublin & 3,4 & 0,7 & 0,5 & 3,4 & 3,3 & 8,9 & 3,8 & $E$ & CW ES \\
\hline Bielsko Biała & 5,4 & 2,8 & 1,2 & 5,7 & 6,8 & 14,5 & 6,3 & $\mathrm{E}$ & CW CE E S \\
\hline Zakopane & 5,6 & 4,2 & 3,8 & 5,5 & 5,9 & 11,6 & 10,4 & $E$ & CE E S \\
\hline Przemyśl & 4,1 & 1,7 & 1,3 & 2,4 & 2,6 & 6,0 & 7,1 & $\mathrm{~S}$ & ES \\
\hline Hala Gąsienicowa & 7,6 & 9,1 & 8,1 & 10,7 & 11,2 & 15,3 & 17,6 & $\mathrm{~S}$ & WW WE CW CE E S \\
\hline Kasprowy Wierch & 7,7 & 7,1 & 6,1 & 9,6 & 9,5 & 15,8 & 15,8 & $S$ & CW CE E S \\
\hline
\end{tabular}

W tab. 6.2 zamieszczono dane, ilustrujące rozkład średnich dobowych sum $M C P$ związanych z typami szlaków niżów śródziemnomorskich.

I tak na przykład, najwyższe średnie opady $M C P$ w Świnoujściu wiążą się z zachodnią gałęzią szlaku C, a opady $M C P$ przekraczające średnią wysokość opadów całkowitych są związane ze szlakami CW i CE. Na Hali Gąsienicowej maksymalny opad MCP wiąże się z południowym szlakiem niżów, przy czym wszystkie typy niżów (WW, WE, CW, CE, E i S) powodują opady $M C P$ większe od średniej obfitości opadów całkowitych. W tabeli 6.2 zamieszczone także „wskaźnikowe” szlaki niżów, określone według najwyższych średnich opadu $M C P\left(M C P_{\mathrm{MAX}}\right)$ i według wskaźnika efektywności Ie $>100 \%$. 


\section{Wnioski}

Średnie dobowe sumy opadów związanych z niżami śródziemnomorskimi są w Polsce wyższe od przeciętnej obfitości opadów atmosferycznych. Wyższe od przeciętnej obfitości całkowitych opadów są te opady MCP, które wiążą się z niżami, wędrującymi znad Morza Śródziemnego przez obszar Polski (klasa C), na wschód (klasa niżów E) oraz na południe od granic kraju (klasa niżów $S$ ).

Najwyższe średnie sumy MCP (>10 mm/dzień) występują w górach i na ich przedpolu, przy czym w Karpatach związane są one z działalnością MEC na szlakach wschodnim i południowym, w Sudetach - z niżami na szlakach centralnych $\mathrm{CW}$ i $\mathrm{CE}$. Można więc wnioskować, że zagrożenie najwyższymi opadami $w$ dorzeczu Odry wiąże się $z$ niżami MEC na szlaku centralnym, $w$ dorzeczu Wisły - $z$ niżami na szlakach wschodnim i południowym.

Najwyższe opady MCP występują po lewej (zachodniej) stronie południkowo biegnących szlaków CW, CE i E, w strefach panowania składowej północnej i wschodniej cyrkulacji cyklonalnej. Na południowym wschodzie Polski najwyższe opady MCP wiążą się też ze szlakiem niżów klasy S - występują na północ od tego szlaku.

Średnie dobowe wysokości opadów MCP pozwalają stwierdzić, że są to wartości stanowiące na ogół około $1 \frac{1}{2}$, a tylko wyjątkowo (na Śnieżce i w Tatrach) 3-krotność średniej obfitości całkowitych opadów. Najwyższe średnie (w Tatrach) sięgają do $18 \mathrm{~mm} /$ dzień. Jednakże największą efektywność (przewyższenie średniej obfitości opadów całkowitych) wykazują MCP na Dolnym Śląsku.

Wysokość, jak i rozmieszczenie MCP na obszarze Polski wykazują wyraźną zależność od położenia trajektorii niżów MEC. O porządku przestrzennym rozkładu opadów MCP na obszarze Polski decyduje w szczególności trajektoria przemieszczania się niżów na szlaku centralnym.

Degirmendžić J., Kożuchowski K., 2015c, Szlaki niżów śródziemnomorskich nad Europa Środkowo-Wschodnią a opady w Polsce. Przegląd Geograficzny, 87, 3, s. 377-397 


\section{Rozdział 7 \\ Niże śródziemnomorskie, zawartość wilgoci w atmosferze i temperatura powietrza}

\section{„Precipitable water"}

Wielkość określana jako zawartość wody opadowej w atmosferze (precipitable water) była dotąd dość rzadko wykorzystywana w polskich badaniach klimatologicznych. W odniesieniu do niżów śródziemnomorskich wielkość ta stanowi jedną z najistotniejszych charakterystyk tych układów cyrkulacyjnych, uznawanych za przyczynę obecności nad Europą ŚrodkowoWschodnią mas powietrza zawierających duże zasoby wilgoci, pochodzącej z parowania ciepłych akwenów morskich położonych na południu kontynentu i umożliwiającej powstawanie wysokich opadów atmosferycznych między innymi w Polsce.

Fortuniak (2003) jako pierwszy przedstawił obraz rocznego cyklu zmian zawartości wody opadowej nad Polską Środkowąa ${ }^{6}$ Maksimum tego cyklu przypada na pierwszą dekadę sierpnia, najniższe wartości utrzymują się w styczniu, lutym i marcu, a średnią roczną wartość reprezentuje słup wody opadowej o wysokości około $15 \mathrm{~mm}$.

Zawartość wody opadowej w atmosferze (PW) jest silnie skorelowana z obfitością opadów w Polsce (DP); współczynnik korelacji średnich pentadowych wartości PW i DP wynosi 0,97 (rys. 7.1).

Średnia roczna wartość ilorazu DP/PW, określającego stopień wykorzystania wilgoci atmosferycznej w powstawaniu opadów (efektywność procesów opadotwórczych), wynosi 0,26 (Kożuchowski, 2015b). Najniższe wartości

${ }^{6}$ Jednym z pierwszych (lub pierwszym) doniesieniem na ten temat był artykuł: Hay J.E., 1970, Precipitable water over Canada. Atmosphere, vol. 8, s. 128-143. 
DP/PW występują w jesieni (średnia w dniach 26-30.09 wynosi 0,19), najwyższe pojawiają się wiosną (średnia w dniach 6-10.04 wynosi 0,30) (rys. 7.2).

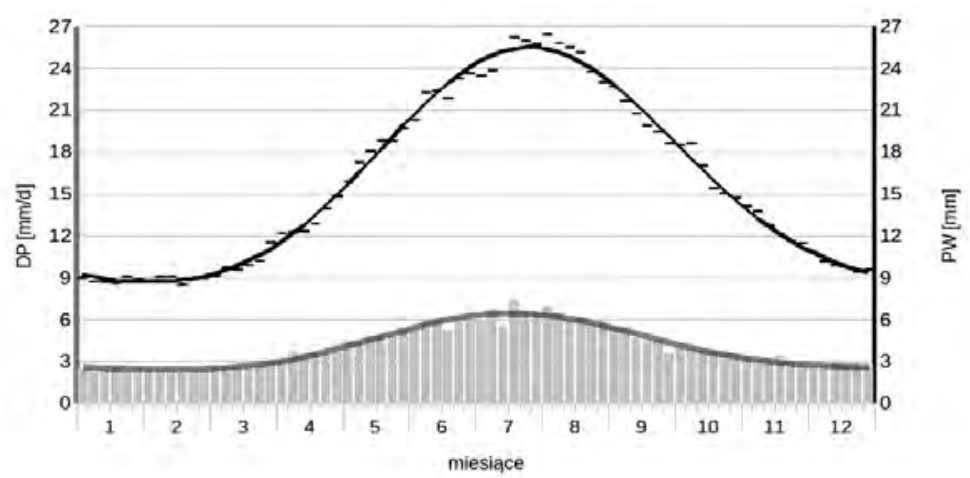

Rys. 7.1. Roczny przebieg średniej pentadowej obfitości opadów w Polsce (DP w mm/dobę, słupki) i średniej pentadowej zawartości wilgoci w atmosferze (PW w mm, kreski) oraz ich składowe harmoniczne

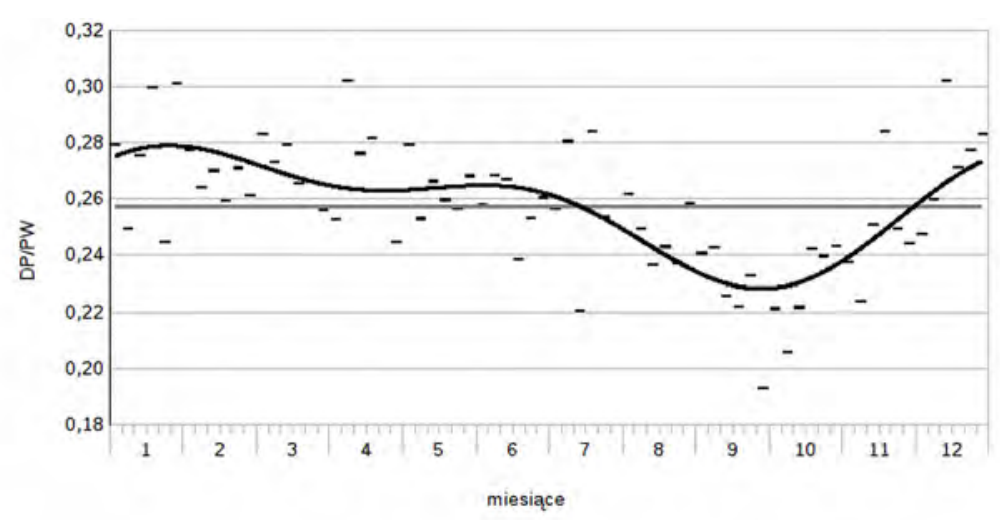

Rys. 7.2. Roczny przebieg stosunku obfitości opadów w Polsce do zawartości wilgoci w atmosferze (DP/PW) - średnie wartości w pentadach (kreski) oraz suma głównych składowych harmonicznych

Malinowska i Miętus (2010) zawartość wody opadowej uznali za jeden z czynników, warunkujących powstawanie opadów o dużym natężeniu w Gdyni. Stwierdzili jednakże występowanie tych silnych opadów przy wysokiej, ale mocno zróżnicowanej zawartości wody opadowej w atmosferze; opadom o dużym natężeniu najczęściej towarzyszy zawartość wody opadowej w granicach 28,1-32,0 mm, a jej wartości bliskie maksymalnym (>36 mm) zdarzają się 
z częstością niewiele wyższą od wartości równych i niższych od średniej rocznej zawartości wody opadowej nad Polską (tab. 7.1).

Tab. 7.1. Rozkład zawartości wody opadowej w atmosferze (PW) związanej z opadami o dużym natężeniu w Gdyni (wg Malinowskiej i Miętusa, 2010)

\begin{tabular}{lccccccc}
\hline PW [mm] & $12,1-16$ & $16,1-20$ & $20,1-24$ & $24,1-28$ & $28,1-32$ & $32,1-36$ & $>36$ \\
Częstość [\%] & 9,6 & 13,5 & 15,4 & 13,5 & 23,1 & 11,5 & 13,5 \\
\hline
\end{tabular}

Bernas i Kolendowicz (2013) stwierdzili, że wysokość maksymalnych opadów w Poznaniu jest ściśle związana ze średnią zawartością wody opadowej w atmosferze, ale pokazali jednocześnie, iż najwyższe opady występują w sytuacjach, kiedy zawartość wody opadowej nie jest zbyt duża $(17 \mathrm{~mm}$ przy opadach powstających w zatoce niżu znad Wielkiej Brytanii lub 24 mm przy opadach związanych z aktywnością niżu z centrum nad południową Polską).

Świątek (2013a) zauważyła, że opady nawalne mogą wielokrotnie przewyższać aktualną zawartość wody opadowej. Suligowski (2013) przewyższenie to nazywa „współczynnikiem efektywności układu”; według tego autora stosunek wysokości maksymalnych opadów dobowych w rejonie Kielc do słupa wody opadowej w atmosferze osiąga wartość 3,23. Stach (2009) wykazał, że maksymalne opady dobowe w Polsce, także w nizinnej części kraju, charakteryzującej się względnie skąpymi opadami, osiągają co najmniej $80 \mathrm{~mm}$. To oznacza, że są one dwukrotnie większe od maksymalnej zawartości wody opadowej w atmosferze, która tylko nieznacznie przekracza wartość $40 \mathrm{~mm}$.

Głównym czynnikiem wymiany wilgoci w atmosferze nad Polską, poza opadami i parowaniem, jest cyrkulacja atmosferyczna, dzięki której kształtuje się poziomy strumień transportu wilgoci. Według Lenarta (1983) średnia gęstość strumienia wilgoci, przenoszonej nad obszar Polski na ogół z zachodu lub z południa, zmienia się od $60-70 \mathrm{~kg} / \mathrm{m} / \mathrm{s}$ w styczniu do ponad $100 \mathrm{~kg} / \mathrm{m} / \mathrm{s}$ w lipcu.

Sobik i Błaś (2010) wykazali, że najwyższe opady powstają przy silnej konwergencji i dużych prędkościach wiatru ponad warstwą graniczną atmosfery. Takie warunki panują $\mathrm{w}$ aktywnym i nie przemieszczającym się zbyt szybko niżu, w atmosferze charakteryzującej się silnie zaznaczoną chwiejnością baroklinową (por. też Ziemiański, 2002). Nasuwa się więc wniosek, że powstawanie opadów o dużym natężeniu uwarunkowane jest dostateczną zawartością wilgoci w atmosferze, ale przede wszystkim układem cyrkulacyjnym, który zapewnia dopływ wilgoci i kondensację pary wodnej. Układ taki 
kształtują przede wszystkim fronty atmosferyczne, z którymi związana jest większość (2/3) ekstremalnych opadów w Polsce (Łupikasza, 2010a).

Ulbrich i in. (2003), którzy analizowali warunki synoptyczne, towarzyszące powodzi w dorzeczu Łaby w 2002 r. ustalili, że czynnikami aktywizującymi niże śródziemnomorskie są: zatoka w polu powierzchni izobarycznej $300 \mathrm{hPa}$ nad zachodnią Europą, silna dywergencja w pobliżu tropopauzy oraz znaczne kontrasty termiczne uczestniczących w cyklonalnej cyrkulacji mas powietrznych. Podano przykład różnicy temperatur powietrza po południowej (Mediolan) i północnej (Konstanca) stronie Alp, wynoszącej $9^{\circ} \mathrm{C}$.

Świątek (2013a), na przykładzie dwu epizodów nawalnych opadów w Polsce Południowej, związanych z działalnością niżów śródziemnomorskich w latach 1997 i 2010, wykazała istnienie nad Polską układu zbieżności mas powietrza polarno-morskiego, polarno-kontynentalnego i powietrza zwrotnikowego, napływających z różnych kierunków odpowiednio na wysokości 500, 2000 i $4000 \mathrm{~m}$ n.p.m. Poziome gradienty temperatury na obszarze Polski osiągały w tych warunkach "około $10^{\circ} \mathrm{C}$.

Konwergencja w dolnej części troposfery i kształtująca się w związku z nią makroskalowa konwekcja są według Sobika i Błasia (2010) bezpośrednimi przyczynami powstawania obfitych opadów w niżach wędrujących lub stagnujących nad Polską i sąsiednimi obszarami. W strefie zbieżności quasistacjonarny front chłodny oddziela ciepłe masy powietrza zwrotnikowego, napływające znad Morza Śródziemnego od chłodnego powietrza polarnego, ulokowanego po zachodniej stronie niżu i tworzącego tzw. „kroplę chłodu” nad Europą Zachodnią. W związku z istniejącymi kontrastami termicznymi atmosfera wykazuje silną baroklinowość, która sprzyja aktywności niżu.

Podobny obraz uzyskał wcześniej Ziemiański (2002), przedstawiając model niestabilności baroklinowej, który odzwierciedla rozwój położonych obok siebie (w odległości rzędu tysiąca kilometrów) komórek ruchu zstępującego w atmosferze nad chłodną „kroplą” i ruchu wstępującego w ciepłym wycinku cyklonu.

Można przyjąć, że kolejnym, a w istocie pierwotnym czynnikiem kształtującym aktywność niżów śródziemnomorskich, skutkującą m.in. wysokimi opadami, jest silnie zróżnicowane pole temperatury. Można ponadto sądzić, iż decydujące pod tym względem są strefowe gradienty temperatury - różnice między wschodnimi i zachodnimi obszarami cyklogenezy, a w rezultacie peryferiami niżów $M E C$.

W literaturze polskiej funkcjonują rozmaite odpowiedniki określenia precipitable water: „woda opadowa” (Niedźwiedź (red.), 2003a), „grubość skon- 
densowanej pary wodnej” (Fortuniak, 2003), „zawartość wody opadowej” (Wibig i Siedlecki, 2007), „zapas wody opadowej (PrecWat)” (Malinowska i Miętus, 2010), „opad potencjalny (PP)” (Suligowski, 2013), „wskaźnik dostępnej wody opadowej (pw)" (Bernas i Kolendowicz, 2013). Krótką dyskusję na temat tych terminów zamieszczono w artykule o obfitości opadów w Polsce (Kożuchowski, 2015a). Warto tu dodać, że według AMS Glossary (2012) równoznacznymi terminami są precipitable water oraz precipitable water vapour.

Rozważając znaczenie różnych spotykanych odpowiedników terminu precipitable water/precipitable water vapour zdecydowano $\mathrm{w}$ niniejszym tekście pisać dalej o „zawartości wilgoci w atmosferze”, używając także akronimu PW.

\section{Cele i materiał badań}

Celem niniejszej części opracowania jest określenie zmian zawartości wilgoci w atmosferze nad Polską, związanych z obecnością niżów śródziemnomorskich MEC nad Europą Środkowo-Wschodnią. Zawartość wilgoci (PW) porównano $\mathrm{z}$ wysokością opadów pochodzenia śródziemnomorskiego $(M C P)$ w celu oceny efektywności wykorzystania wilgoci atmosferycznej w procesach powstawania opadów.

Obliczono współczynniki DP/PW, tj. ilorazy obfitości opadów i zawartości wilgoci w atmosferze. Przedstawiono także średnią zawartość wilgoci w atmosferze podczas występowania najwyższych dobowych opadów pochodzenia śródziemnomorskiego ( $M C P>90 \mathrm{~mm} /$ dobę) .

Ponadto przedstawiono średnie pole PW oraz średnie pole temperatury przyziemnych warstw powietrza nad Europą, uformowane pod wpływem aktywności MEC. Wykonano ocenę korelacji między zawartością wilgoci w atmosferze i gradientami w polu temperatury a wysokością $M C P$ w Polsce.

W pracy wykorzystano uśrednione położenie zarejestrowanych szlaków niżowych w ramach czterech wyróżnionych klas MEC (zob. rozdz. 6), przy czym pominięto pewną nieliczną grupę niżów klasy BS, wędrujących „szlakiem wstecznym" - na zachód (rys. 7.3).

W analizie opadów atmosferycznych, związanych z oddziaływaniem niżów śródziemnomorskich wykorzystano dobowe sumy opadów z 66 stacji równomiernie rozmieszczonych na obszarze Polski z okresu 1958-2008. Sumy te powiązano z obecnością niżów $M E C$ na wydzielonych szlakach ich przemieszczania się nad Europą Środkowo-Wschodnią. Średnie obszarowe sumy dobowe opadów MCP w Polsce (średnie z 66 stacji) wyznaczono na podstawie 
wartości z dni, kiedy $M E C$ znajdowały się na tzw. opadotwórczym odcinku określonego szlaku lub w jego pobliżu (obszerniejszy opis procedury wyznaczania opadów MCP znajduje się w rozdz. 3).

Zawartość wilgoci w atmosferze nad Polską (PW) określono na podstawie danych reanaliz NCEP/NCAR (Kalnay i in., 1996). Obliczono średnie wartości PW na podstawie sześciu punktów gridowych o współrzędnych $15^{\circ} \mathrm{E}, 17,5^{\circ} \mathrm{E}$, $20^{\circ} \mathrm{E}$ i $22,5^{\circ} \mathrm{E}$ na równoleżniku $52,5^{\circ} \mathrm{N}$ oraz $20^{\circ} \mathrm{E}$ i $22,5^{\circ} \mathrm{E}$ na szerokości geograficznej $50^{\circ} \mathrm{N}$. Wyznaczono średnie dobowe wartości PW dla każdego dnia w roku, a następnie obliczono względne odchylenia PW od średniej wieloletniej wartości PW w dniach występowania opadów $M C P$.

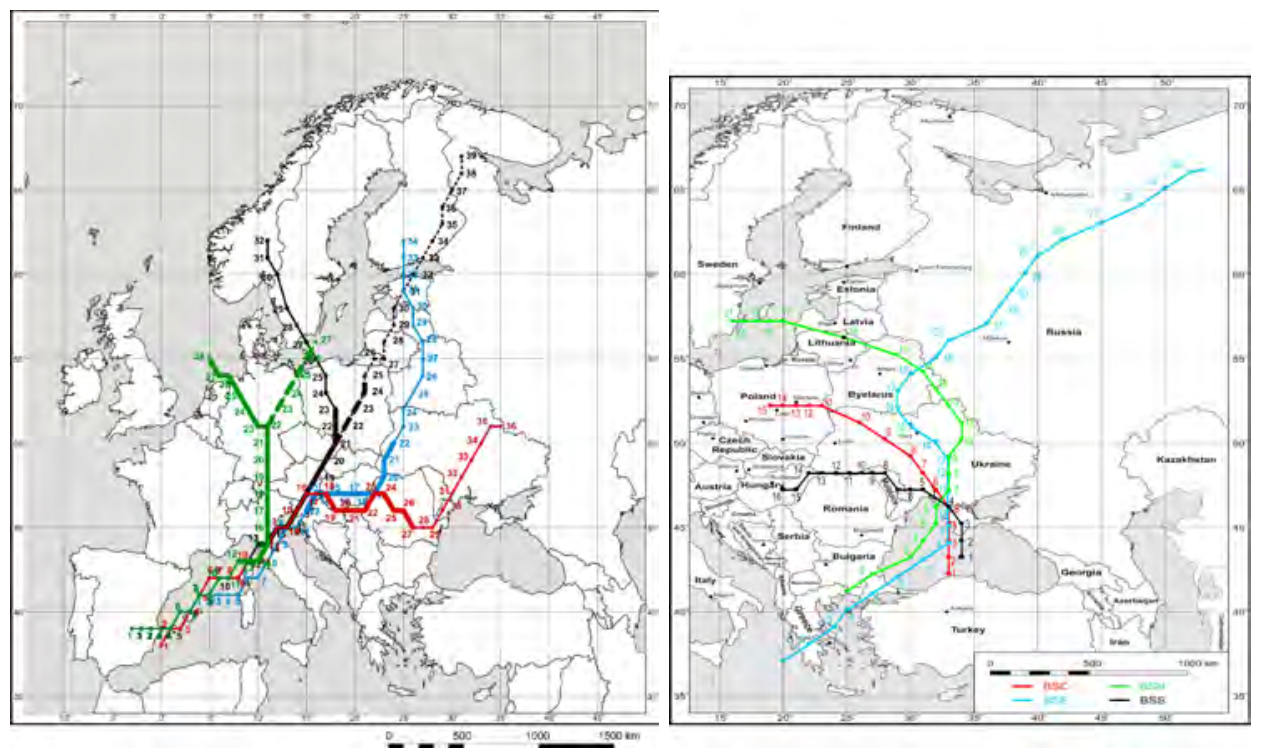

Rys. 7.3. Lewy panel: średnie położenie szlaków niżów śródziemnomorskich (MEC) przemieszczających się nad Europą Środkowo-Wschodnią. E - szlak wschodni (niebieski), C - szlak centralny (z gałęziami CW i CE; czarny), W - szlak zachodni (z gałęziami WW i WE; zielony), S - szlak południowy (czerwony). Prawy panel: średnie trajektorie niżów czarnomorskich typu BS (BSN - trajektoria północna, BSC - centralna, BSS - południowa, BSE - wschodnia). Numeracja punktów na trajektorii zgodnie z ruchem $M E C$

W pracy o zawartości wody opadowej w atmosferze nad Europą Wibig i Siedlecki (2007) stwierdzili zgodność danych o zawartości wody opadowej, otrzymywanych w wyniku reanaliz NCEP/NCAR z wynikami analizy radiosondaży atmosfery, które można uznać za podstawowe źródło danych o profilu 
wilgotności właściwej powietrza, niezbędnych do określeniu masy słupa wody w atmosferze. Wykorzystane tu wartości PW można więc uznać za dostatecznie adekwatne miary zasobów wilgoci atmosferycznej.

\section{Szlaki niżów MEC, zawartość wilgoci w atmosferze i opady w Polsce}

Niże śródziemnomorskie, obejmujące swym wpływem obszar Polski przynoszą wzrost zawartości wilgoci w atmosferze, który ponadto różnicuje się w zależności od położenia i szlaku przemieszczania się niżu. W analizowanym okresie 1958-2008 odnotowano 563 dni, w których niże śródziemnomorskie znajdowały się na tzw. opadotwórczych odcinkach swych szlaków. Względna częstość występowania tych dni wynosi zaledwie ok. 3\%. Najczęstsze były niże wędrujące szlakiem centralnym C (prawie 46\%), najrzadziej występowały niże na szlaku zachodnim W (10\%) (tab. 7.2).

Obliczone średnie wartości PW w dniach występowania MEC oraz porównanie tych wartości ze średnimi dobowymi PW w wieloleciu (tj. określenie względnych odchylen " $\Delta$ ” od wartości średniej z cyklu rocznego PW) pozwala ocenić średni, „klimatyczny” wpływ cyrkulacji sterowanej przez MEC na zawartość wilgoci w atmosferze nad Polską. Tab. 7.2 zawiera wyniki tych ocen, z których widać, że średnie PW nad Polską podczas występowania MEC na opadotwórczych odcinkach torów jest o $14,5 \%$ wyższa od średnich wieloletnich dobowych PW (odpowiednio $\mathrm{PW}=18,14$ i PW=15,93 $\mathrm{mm}$ ). Dla niżów wędrujących torem $\mathrm{W}$ i powodujących adwekcję południową w Polsce, jest ona o 21,6\% wyższa i wynosi $19,53 \mathrm{~mm}$, a gdy niże wędrują torem E i przeważa adwekcja z północy - zawartość wilgoci $(\mathrm{PW}=16,02 \mathrm{~mm})$ jest tylko o 4,5\% większa od średniej. Pojawienie się $M E C$ na szlaku zachodnim (W) i centralnym (C) skutkuje wzrostem wartości PW nad Polska średnio o 5 i 4 mm, wzrosty PW związane z niżami na szlakach $\mathrm{E}$ i S są o połowę mniejsze (rys. 7.4). Zwraca uwagę znaczny spadek zawartości wilgoci w atmosferze, następujący po przejściu niżu szlakiem E, świadczący najprawdopodobniej o adwekcji chłodnego i suchego powietrza na zachodnich peryferiach niżu.

Średnia zawartość wilgoci podczas występowania MEC jest wyższa od jej średniej wieloletniej, ale poszczególne wartości PW w dniach występowania niżów $M E C$ wykazują znaczną zmienność - najwyższe i najniższe wartości są bliskie ekstremom PW w Polsce: przy niżach MEC notowano wartości PW od 3,77 do 36,58 mm (tab. 7.2). Zmienność ta może znaleźć wyjaśnienie 
w charakterystycznych cechach układów cyrkulacyjnych $M E C$, w szczególności związanej z nimi zbieżności różnorodnych mas powietrza - zarówno wilgotnego powietrza „śródziemnomorskiego”, jak i bardziej suchego powietrza napływającego z północy lub ze wschodu. Zróżnicowanie PW w zależności od szlaku wędrówki $M E C$ potwierdza ten wniosek.

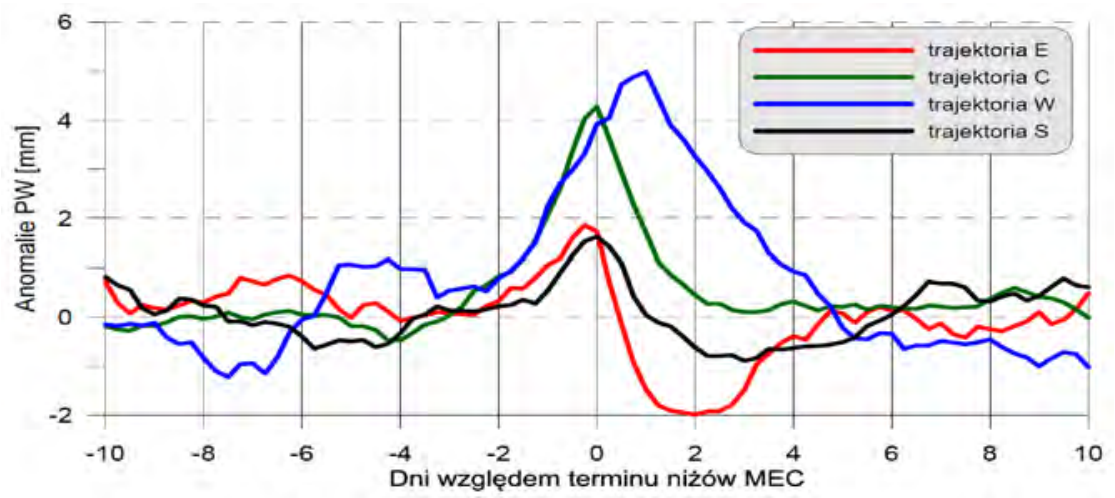

Rys. 7.4. Przebieg anomalii dobowych wartości PW nad Polską uśrednionych względem terminu wystąpienia niżów $M E C$ na opadotwórczych odcinkach szlaku E, C, W i S

Tab. 7.2. Zawartość wilgoci w atmosferze nad Polską (PW) w dniach występowania MEC na opadotwórczych odcinkach szlaków W, C, S, E oraz jej wartości wieloletnie (1958-2008) (wg Degirmendžića i Kożuchowskiego, 2015b)

\begin{tabular}{|c|c|c|c|c|c|c|c|}
\hline \multirow{2}{*}{$\begin{array}{l}\text { Szlaki niżów } \\
\text { MEC }\end{array}$} & \multicolumn{3}{|c|}{ Częstość } & \multicolumn{4}{|c|}{ PW } \\
\hline & N & F1 & F2 & $\begin{array}{r}\text { Minimum } \\
{[\mathrm{mm}]}\end{array}$ & $\underset{[\mathrm{mm}]}{\text { Maksimum }}$ & $\begin{array}{r}\text { Średnia } \\
{[\mathrm{mm}]}\end{array}$ & $\Delta$ \\
\hline W & 58 & 0,31 & 10,3 & 6,44 & 31,08 & 19,53 & 0,216 \\
\hline C & 258 & 1,39 & 45,8 & 5,30 & 36,41 & 19,36 & 0,197 \\
\hline $\mathrm{S}$ & 126 & 0,68 & 22,4 & 4,84 & 36,58 & 17,03 & 0,096 \\
\hline$E$ & 121 & 0,65 & 21,5 & 3,77 & 31,99 & 16,02 & 0,045 \\
\hline$\Sigma M E C$ & 563 & 3,02 & 100 & 3,77 & 36,58 & 18,14 & 0,145 \\
\hline PW 1958-2008 & $\begin{array}{r}18615 \\
\text { (365 dni } \times 51 \text { lat) }\end{array}$ & .00 & - & 1,86 & 40,97 & 15,93 & 0,000 \\
\hline
\end{tabular}

$\Delta$ - względne odchylenie PW od średniej wieloletniej zawartości wilgoci,

$\mathrm{N}$ - liczba dni kiedy niże MEC znajdowały się na opadotwórczych odcinkach ich trajektorii $w$ okresie 51 lat,

F1 - częstość w \% sumy rocznej,

F2 - częstość w \% liczby dni z opadem MCP. 
Średnia obfitość MCP jest wyższa od obfitości opadów całkowitych w Polsce i wynosi 5,8 mm/dobę. Stanowi to $32 \%$ średniej zawartości wilgoci w atmosferze $\mathrm{w}$ dniach występowania niżów MEC. Procent ten jest wyższy od tego, który charakteryzuje obfitość całkowitych opadów w Polsce i średnią zawartość wilgoci $(\mathrm{DP} / \mathrm{PW}=0,26)$ (tab. 7.3).

Torowi E niżów odpowiada największa obfitość opadów $(5,9 \mathrm{~mm} /$ dobę $)$ przy najmniejszej zawartości wilgoci $(16 \mathrm{~mm})$ : stosunek DP/PW sięga 0,37. Torowi C odpowiada stosunek 0,29. Mała obfitość opadów śródziemnomorskich i niskie ilorazy DP/PW związane są z torami W i S. Stosunki DP/PW są w tych przypadkach niższe od średniej krajowej 0,26 i wynoszą odpowiednio 0,11 i 0,19 (tab. 7.3).

Tab. 7.3. Średnia obfitość MCP (DP) i średnia zawartość wilgoci nad Polską (PW) w zależności od toru $M E C$, średnia wieloletnia obfitość całkowitych opadów w Polsce

(DP-PL) oraz średnie wieloletnie zawartości wilgoci (PW-PL) oraz współczynnika DP/PW (wg Degirmendžića i Kożuchowskiego, 2015b)

\begin{tabular}{lccc}
\hline Tor MEC & $\begin{array}{c}\text { DP* } \\
\text { [mm/dobę }\end{array}$ & $\begin{array}{c}\text { PW* } \\
\text { [mm] }\end{array}$ & DP/PW \\
\hline W & 2,2 & 19,5 & 0,11 \\
C & 5,6 & 19,4 & 0,29 \\
S & 3,3 & 17,0 & 0,19 \\
E & 5,9 & 16,0 & 0,37 \\
\hline$\Sigma M E C$ & 5,8 & 18,1 & 0,32 \\
\hline PL & 4,1 & 15,9 & 0,26 \\
\hline
\end{tabular}

* - wartości uśredniono z terminów kiedy niże MEC znajdowały się na opadotwórczych odcinkach ich trajektorii

Zróżnicowanie ilorazów DP/PW, które są wskaźnikiem wykorzystania wilgoci atmosferycznej w procesie powstawania opadu, kształtują związane ze szlakami MEC kierunki adwekcji nad Polską: przy adwekcji północnej (szlak E) wskaźnik sięga 0,37, przy adwekcji południowej (szlak W) wynosi tylko 0,11, chociaż wartość PW jest przy tym wysoka (tab. 7.3). Przejawia się także reguła, zgodnie z którą największe opady występują na zachód (lub po lewej stronie, patrząc w kierunku ruchu układów) od położenia ośrodków niżowych i zarazem od szlaków ich przemieszczania się (Wrona, 2008; Sobik i Błaś, 2010, Świątek, 2013b).

Opady MCP charakteryzuje istotna, ale niezbyt silna korelacja z zawartością wilgoci w atmosferze nad Polską. Dla opadów, związanych z niżami, 
wędrującymi torem zachodnim współczynnik korelacji tych dwu zmiennych (PW i MCP) wynosi 0,44, natomiast współczynnik korelacji cząstkowej, z wyeliminowanym wpływem korelacji MCP z poziomym gradientem temperatury nad Europą między 0 i $25^{\circ} \mathrm{E}$ - osiąga wartość 0,51 (tab. 7.4). Charakterystyczną cechą korelacji opadów i zawartości wilgoci w atmosferze jest jej związek $\mathrm{z}$ wielkością zasobów wilgoci. W niżach na szlaku $\mathrm{W}$, zasoby te są największe w związku z południowym kierunkiem adwekcji nad Polską ( $\Delta \mathrm{PW}=3,53 \mathrm{~mm})$, a opady wykazują najsilniejszy związek korelacyjny z ilością wilgoci. W niżach na szlaku wschodnim i północnej adwekcji, zawartość wilgoci w atmosferze nad Polską jest względnie mała $(\Delta \mathrm{PW}=1,09 \mathrm{~mm})$, a jej korelacja $\mathrm{z}$ opadami również niewysoka $(r=0,28)$. Warto tu jeszcze raz wskazać, że obfitość opadów w niżach na szlaku W jest najmniejsza, na szlaku E - największa (por. tab. 7.3). Okazuje się wiec, iż niewielkie opady są silniej skorelowane z zawartością wilgoci od obfitych opadów, powstających w słabym związku z zawartością wilgoci. Wniosek ten znajduje potwierdzenie m.in. w dalej przedstawionych analizach, dotyczących opadów ekstremalnych.

Tab. 7.4. Średnie anomalie zawartości wilgoci w atmosferze nad Polską $(\Delta \mathrm{PW})$ oraz współczynniki korelacji prostej (r) i cząstkowej (r*) wysokości opadów $M C P$ i zawartości wilgoci w atmosferze $(\Delta \mathrm{PW})$. Anomalie obliczono jako różnice między wartościami średniej PW w dniach z niżami $M E C$ na odcinkach opadotwórczych trajektorii oraz analogicznymi średnimi z wielolecia 1958-2008

\begin{tabular}{lccc}
\hline Tor & $\mathbf{\Delta P W}[\mathrm{mm}]$ & $\mathbf{r}$ & $\mathbf{r}^{*}$ \\
\hline W & 3,53 & $\mathbf{0 , 4 4}$ & $\mathbf{0 , 5 1}$ \\
$\mathrm{C}$ & 3,28 & $\mathbf{0 , 3 9}$ & $\mathbf{0 , 3 8}$ \\
$\mathrm{S}$ & 1,29 & $\mathbf{0 , 3 1}$ & $\mathbf{0 , 3 0}$ \\
$\mathrm{E}$ & 1,09 & $\mathbf{0 , 2 8}$ & $\mathbf{0 , 3 0}$ \\
\hline
\end{tabular}

r* - korelacja czastkowa $z$ wyeliminowanym wpływem strefowego gradientu temperatury (TzaCH - TwsCH). Sektory uśredniania temperatury na zachodzie i wschodzie Europy jak na rys. 7.15-7.18. Pogrubiono współczynniki istotne na poziomie 0,05.

Średnie wysokości opadów MCP na obszarze Polski, niezależnie od toru przemieszczania się $M E C$, są pozytywnie skorelowane z odchyleniami zawartości wilgoci od jej wieloletniego cyklu rocznego ( $\Delta$ PW). Jednakże tylko 10,2\% zmienności opadów wyjaśniają zmiany zawartości wilgoci w atmosferze. Według równania regresji liniowej przyrost wartości PW o $10 \mathrm{~mm}$ powoduje wzrost opadu MCP jedynie o 3,2 $\mathrm{mm}$ :

$$
M C P=0,32 \Delta \mathrm{PW}+3,7[\mathrm{~mm}]
$$


"Siłę” związku wartości MCP i PW określa współczynnik korelacji $r=0,32$, który spełnia warunek statystycznej istotności na poziomie 0,05 .

Obraz związku korelacyjnego (rys. 7.5) skłania do powtórzenia wniosku o znacznej zmienności PW w dniach występowania opadów MCP. Wysokość tych opadów wykazuje tendencję rosnącą wraz ze wzrostem PW, ale nie można twierdzić, że to zawartość wilgoci w atmosferze jest czynnikiem decydującym o obfitości opadów, związanych z niżami śródziemnomorskimi.

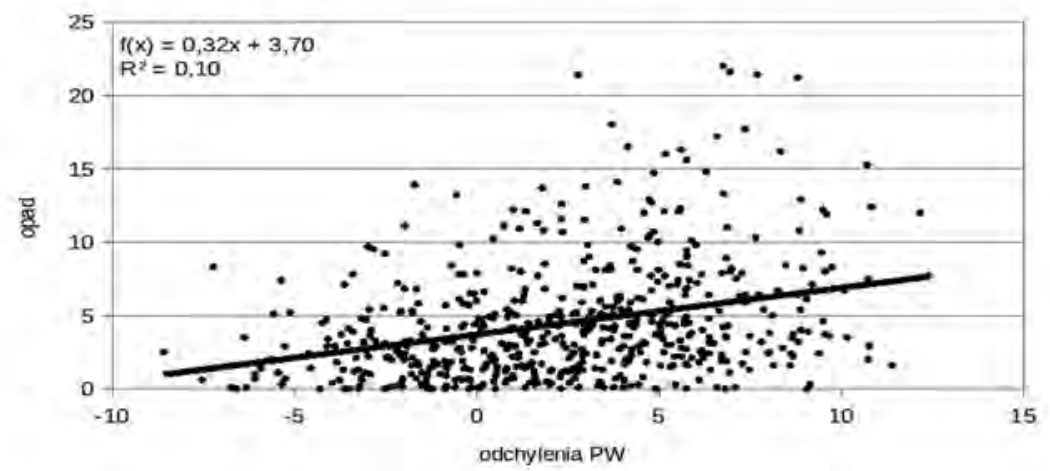

Rys. 7.5. Średni opad $M C P$ [mm] versus odchylenia PW [mm] od cyklu rocznego w terminach kiedy $M E C$ usytuowane były na opadotwórczych odcinkach trajektorii E, C, W oraz S w okresie 1958-2008. Wartości MCP oraz PW uśredniono dla obszaru Polski. Przedstawiono linię regresji wraz z równaniem i współczynnikiem determinacji $\left(\mathrm{R}^{2}\right)$

\section{Ekstremalne opady i zawartość wilgoci w atmosferze}

Na podstawie wartości średnich można uznać, że opady „zużywają” zaledwie część zapasu wilgoci atmosferycznej. Uwzględniając jednak maksymalne sumy opadów dostrzegamy, że wysokość dobowego opadu, w tym opadu MCP, może kilkukrotnie przewyższać aktualną zawartość wilgoci w atmosferze. Jest to skutek adwekcji wilgotnego powietrza w sprzyjającym kondensacji pary wodnej układzie cyrkulacyjnym.

W tab. 7.5 zestawiono wartości dobowych sum opadu, zawartości wilgoci w atmosferze, jej odchylenia od średniej wieloletniej oraz ilorazu DP/PW, odpowiadające 13 przypadkom dobowych sum opadów MCP o wysokościach większych od $90 \mathrm{~mm}$. Były to opady od $99 \mathrm{~mm} /$ dobę (Kraków, 9.09 .1963 r.) do 
$234 \mathrm{~mm} /$ dobę (Hala Gąsienicowa, 8.07.1997 r.). Ponadto zestawiono te same charakterystyki odpowiadające skrajnie wysokim opadom w Polsce, przekraczającym $200 \mathrm{~mm} /$ dobę, w tym „rekordu” opadów dobowych - sięgającego $300 \mathrm{~mm}$ opadu $\left(\mathrm{P}_{\text {EXTR }}\right)$ na Hali Gąsienicowej z dnia 30.06.1973 r.

Tab. 7.5. Obfitość (DP) najwyższych opadów dobowych i odpowiadająca im zawartość wilgoci w atmosferze (PW), jej względne odchylenia od średniej wieloletniej $(\Delta)$ oraz ilorazy DP/PW (wg Degirmendžića i Kożuchowskiego, 2015b)

\begin{tabular}{|c|c|c|c|c|}
\hline Wartość & $\mathrm{DP}$ [mm/doba] & $\mathrm{PW}[\mathrm{mm}]$ & $\Delta$ & DP/PW \\
\hline \multicolumn{5}{|c|}{$M C P_{\mathrm{MAX}}>90 \mathrm{~mm}(\mathrm{n}=13)$} \\
\hline Minimum & 99 & 23,50 & $-0,076$ & 3,24 \\
\hline Średnia & 143 & 29,81 & 0,187 & 4,88 \\
\hline Maksimum & 234 & 35,30 & 0,407 & 7,88 \\
\hline \multicolumn{5}{|c|}{$P_{\text {MAX }}>200 \mathrm{~mm}(n=9)$} \\
\hline Średnia & 225 & 29,23 & 0,267 & 7,74 \\
\hline$P_{\text {EXTR }}$ & 300 & 30,56 & 0,304 & 9,82 \\
\hline
\end{tabular}

$M C P_{\text {MAX }}$ - maksymalne opady pochodzenia śródziemnomorskiego (MCP),

$\mathrm{P}_{\mathrm{MAX}}$ - najwyższe opady $w$ Polsce,

$\mathrm{P}_{\mathrm{EXTR}}$ - maksimum dobowe $z$ dnia 30.06.1973 r.,

$\mathrm{n}$ - liczba przypadków.

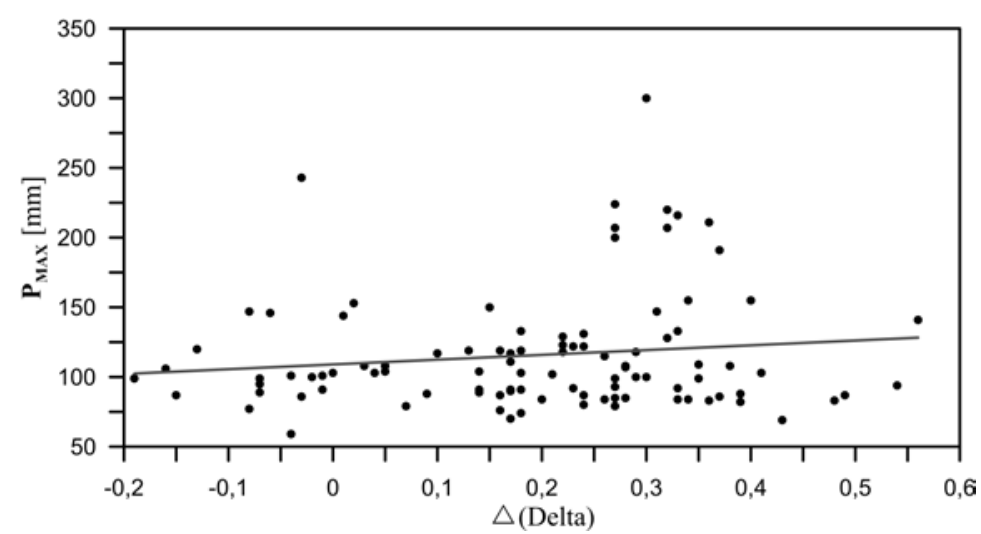

Rys. 7.6. Najwyższe sumy dobowe opadów w Polsce $\left(\mathrm{P}_{\mathrm{MAX}}\right)$ w zależności od odchyleń zawartości wilgoci w atmosferze ( $\Delta$-Delta). Uwzględniono 100 przypadków maksymalnych opadów dobowych z lat 1958-2008. $\Delta$ - względne odchylenie zawartości wilgoci (PW) od średniej wieloletniej PW z dnia wystąpienia opadu $\mathrm{P}_{\mathrm{MAX}}$

Ekstremalnie wysokie opady $M C P$ występowały w dniach, w których zawartość wilgoci $\mathrm{w}$ atmosferze nad Polską utrzymywała się na poziomie od 23,5 do 35,3 mm, średnio był to poziom bliski wartości $30 \mathrm{~mm}$, czyli dwukrot- 
nie przekraczającej średnią wartość wieloletnią. Zdarzyły się jednak sytuacje, w których wysokim opadom towarzyszyła zawartość wilgoci nieco niższa od średniej dobowej z wielolecia $(\Delta<0)$. Najwyższe opady $M C P$ były 3-8-krotnie wyższe od zawartości wilgoci w atmosferze $(3,24<\mathrm{DP} / \mathrm{PW}<7,88$, tab. 7.5). Skrajne sumy dobowe (DP $>200 \mathrm{~mm}$ ) pojawiły się w warunkach, kiedy zawartość wilgoci w atmosferze przewyższała wyraźnie średnią wieloletnią, a opad niemal 8-krotnie, a w przypadku rekordowego opadu z 30.06.1973 r. - prawie 10-krotnie przekroczył aktualną wartość PW.

Wraz ze wzrostem wysokości opadów ekstremalnych rośnie iloraz DP/PW, który obrazuje wydajność procesów formujących opad. Występuje także tendencja wzrostowa wartości $\Delta$, odzwierciedlającej odchylenie zawartości wilgoci PW od jej średniej dobowej (rys. 7.6).

Opadom ekstremalnie wysokim towarzyszy przeważnie „nadwyżka” zawartości wilgoci. Wzrost wysokości opadów ekstremalnych ( $\left.\mathrm{P}_{\mathrm{MAx}}\right)$ przy rosnącej nadwyżce wilgoci $(\Delta)$ można opisać równaniem $\mathrm{P}_{\mathrm{MAX}}=34,3 \Delta+109 .{ }^{7}$

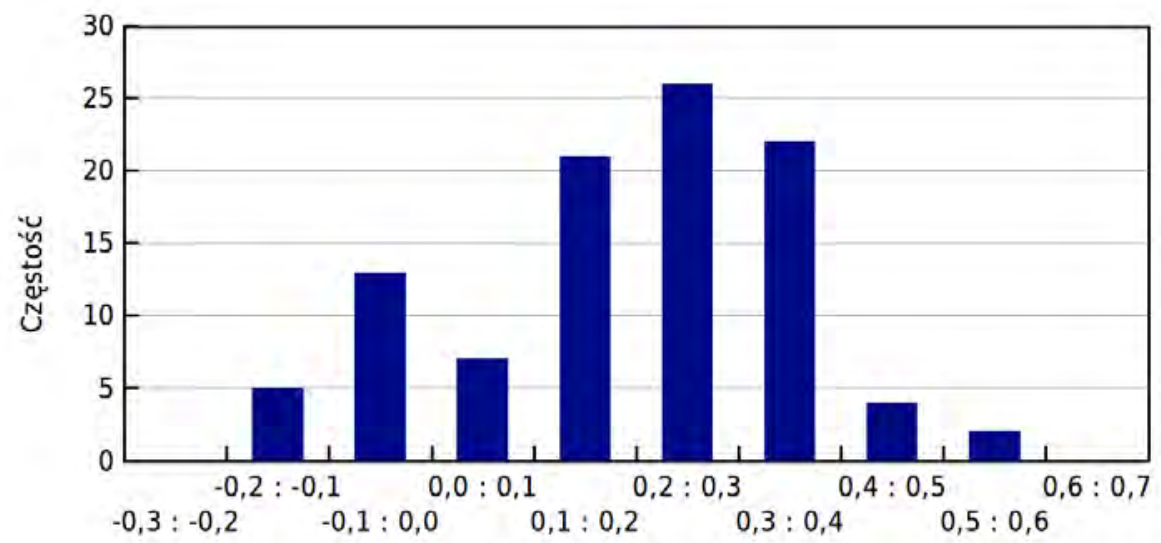

Przedziały delta

Rys. 7.7. Rozkład częstości odchyleń dobowych wartości PW ( $\Delta$-delta) w dniach występowania maksymalnych opadów w Polsce. Objaśnienia jak na rys. 7.6

Zależność wysokości opadu od zawartości wilgoci nie jest jednak istotna; zmienność odchylenia $\Delta$ wyjaśnia zaledwie $2 \%$ wariancji opadów maksymalnych, które mogą powstawać także przy „niedoborach” wilgoci w atmosferze. Wydajność procesu wykorzystania wilgoci atmosferycznej w powstawaniu

7 Równanie opisuje związek z zawartością wilgoci w atmosferze $(\Delta) 100$ najwyższych sum dobowych opadu $\mathrm{P}_{\mathrm{MAX}}$, obserwowanych w Polsce w latach 1958-2008, niezależnie od ich genezy. 
opadów może być bardzo różna. Większość skrajnie wysokich opadów występuje jednak przy dużych nadwyżkach wilgoci, sięgających do około $150 \%$ jej średniej zawartości w atmosferze (rys. 7.7). Najczęściej maksymalnym opadom towarzyszą jednak „nadwyżki” PW w granicach 20-30\%. Dotyczy to zarówno opadów pochodzenia śródziemnomorskiego $(M C P)$, jak i opadów o innej genezie.

Zawartość wilgoci w atmosferze nad Polską (PW) charakteryzuje się prawostronnie skośnym rozkładem częstości (rys. 7.8), a jej skrajne wartości w latach 1958-2008 zawierały się w przedziale 1,86 $\mathrm{mm} \leq \mathrm{PW} \leq 40,97 \mathrm{~mm}$ przy średniej 15,93 mm.

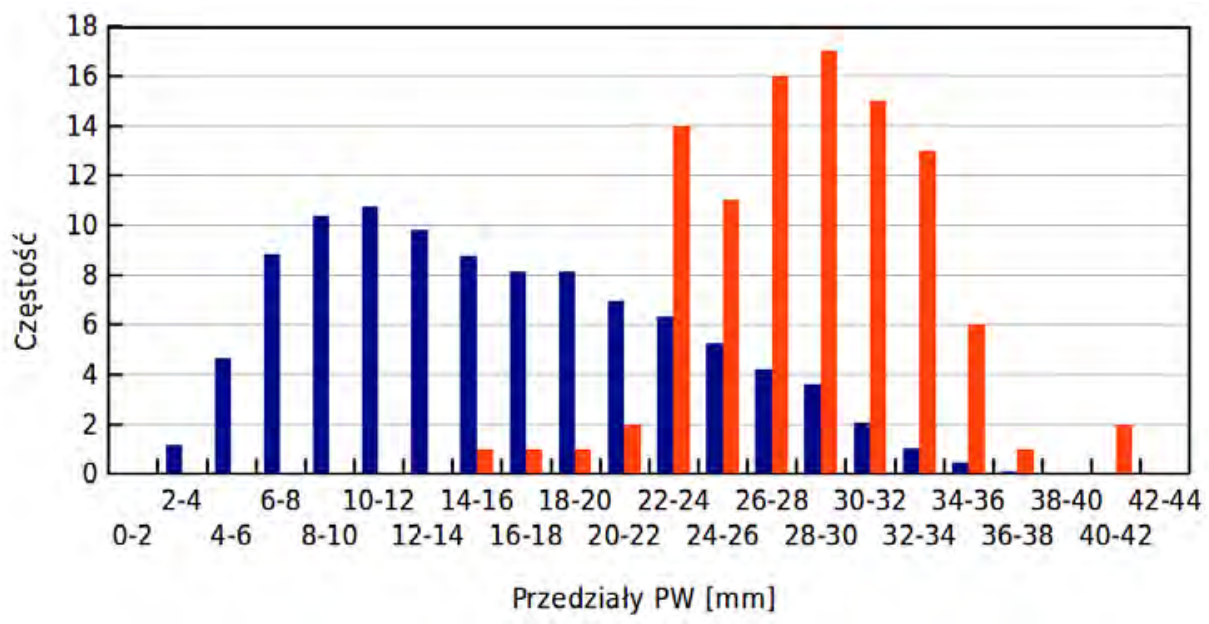

Rys. 7.8. Rozkład średnich dobowych zawartości wilgoci w atmosferze nad Polską w okresie 1958-2008 (PW - niebieski) oraz rozkład zawartości wilgoci w terminach wystąpienia 100 przypadków ekstremalnych opadów dobowych (czerwony)

Maksymalne opady dobowe $\left(\mathrm{P}_{\mathrm{MAX}}\right)$ związane są ze zróżnicowaną, ale na ogół wysoką zawartością wilgoci w atmosferze. Rozkład częstości wartości PW, odpowiadających wystąpieniu maksymalnych opadów dobowych w Polsce (tj. wybranych 100 przypadków maksimów opadowych) wskazuje, że najczęściej maksymalne opady dobowe występowały przy zawartości wilgoci w atmosferze $28 \leq \mathrm{PW} \leq 30 \mathrm{~mm}, 95 \%$ opadów $\mathrm{P}_{\mathrm{MAX}}$ wystąpiło przy wartościach PW $>22 \mathrm{~mm}$, ponad połowa przy wartościach PW > $28 \mathrm{~mm}$. Rozkład ten wyróżnia się znamiennie na tle rozkładu charakteryzującego cały zbiór PW (rys. 7.8). Jest za to bardzo podobny do cytowanego wyżej (tab. 7.1) rozkładu wartości PW przy dużych opadach w Gdyni (Malinowska i Miętus, 2010). 


\section{Niże MEC a zawartość wilgoci w atmosferze nad Europą i północnym Atlantykiem}

Układom cyklonalnym na ich torach przemieszczania się nad Europą Środkowo-Wschodnią towarzyszy charakterystyczne rozmieszczenie wilgoci $\mathrm{w}$ atmosferze. Wschodnim peryferiom MEC odpowiadają nadwyżki wilgoci atmosferycznej, w zachodnich sektorach występują niedobory wilgoci. Izolinie anomalii PW przybierają postać typowego dipola, z „biegunami” rozmieszczonymi odpowiednio po wschodniej i zachodniej stronie toru MEC. Zerowe wartości anomalii PW rozciągają się mniej więcej wzdłuż szlaku niżowego. Prawidłowości te można $\mathrm{z}$ łatwością dostrzec na podstawie analizy map anomalii PW, związanych z niżami MEC na torach W, C, S i E (rys. 7.9).

Niżom $M E C$ na torze zachodnim (W) odpowiada kulminacja nadwyżek PW, sięgająca $6 \mathrm{~mm}$ i zlokalizowana nad południowym Bałtykiem i wybrzeżami Niemiec. Jednocześnie nad południową Anglią, a także Półwyspem Iberyjskim atmosfera charakteryzuje się niedoborami wilgoci i anomaliami PW $<-2$ mm (rys. 7.9, tor W)

Niże na torze centralnym $(\mathbf{C})$ kształtują podwyższoną zawartość wilgoci $\mathrm{w}$ atmosferze nad Polską ( $\Delta \mathrm{PW} \geq 4 \mathrm{~mm})$, niedobory wilgoci $(\Delta \mathrm{PW} \leq-3 \mathrm{~mm}$ ) powstają natomiast nad Francją (rys. 7.9, tor C).

Układ anomalii PW związany z niżami MEC na szlaku południowym (S) reprezentują izolinie przesunięte na południe względem ich położenia, odpowiadającego niżom ze szlaku centralnego. Kulminacja nadwyżek PW leży nad Słowacją $(\Delta \mathrm{PW}=4 \mathrm{~mm})$, depresja występuje nad południową Francją $(\Delta \mathrm{PW}=-2 \mathrm{~mm})$ (rys. 7.9, tor $\mathrm{S})$.

Największe kontrasty anomalii PW związane są z niżami na szlaku wschodnim. Wysokie dodatnie anomalie $(\Delta \mathrm{PW}=6 \mathrm{~mm})$ pojawiają się nad Białorusią, ujemne wartości $(\triangle \mathrm{PW}=-4 \mathrm{~mm}$ ) reprezentuje depresja zlokalizowana nad południową Francją (rys. 7.9, tor E).

Na przykładzie niżów $M E C$, poruszających się szlakiem wschodnim ( Vb) przedstawiono cyrkulacyjne uwarunkowania zróżnicowanego pola PW nad Europą. Rys. 7.10 przedstawia strumienie wilgoci atmosferycznej uruchamiane wskutek działalności MEC na szlaku wschodnim. Widać, że dodatnia anomalia PW nad Białorusią (rys. 7.9, tor E) jest skutkiem napływu wilgoci w masach powietrza znad Morza Śródziemnego: „gęsty” strumień wilgoci biegnie od Korsyki i Sardynii, przez południowe Włochy i Bałkany, właśnie nad Białoruś. Dalej, poprzez Litwę, wilgoć dociera od północy także nad Polskę. Tor strumienia ma najwyraźniej cyklonalną krzywiznę (por. rys. 7.11) 

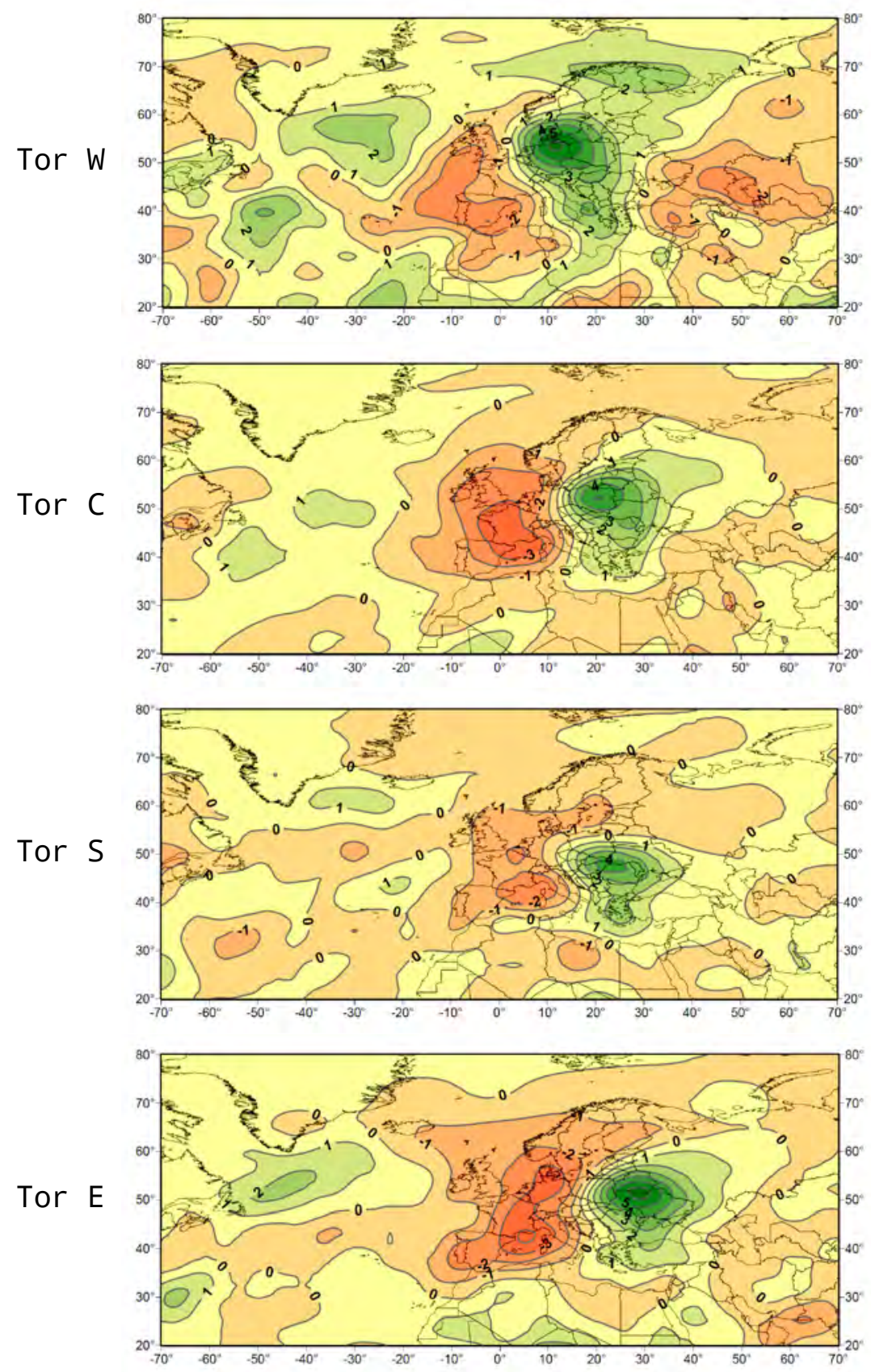

Rys. 7.9. Anomalie słupa wody opadowej (PW) w Eurazji [mm]. Anomalie obliczono jako różnice między wartościami średniej PW w dniach z niżami $M E C$ na odcinkach opadotwórczych trajektorii W, C, S i E oraz analogicznymi średnimi z wielolecia 1958-2008 


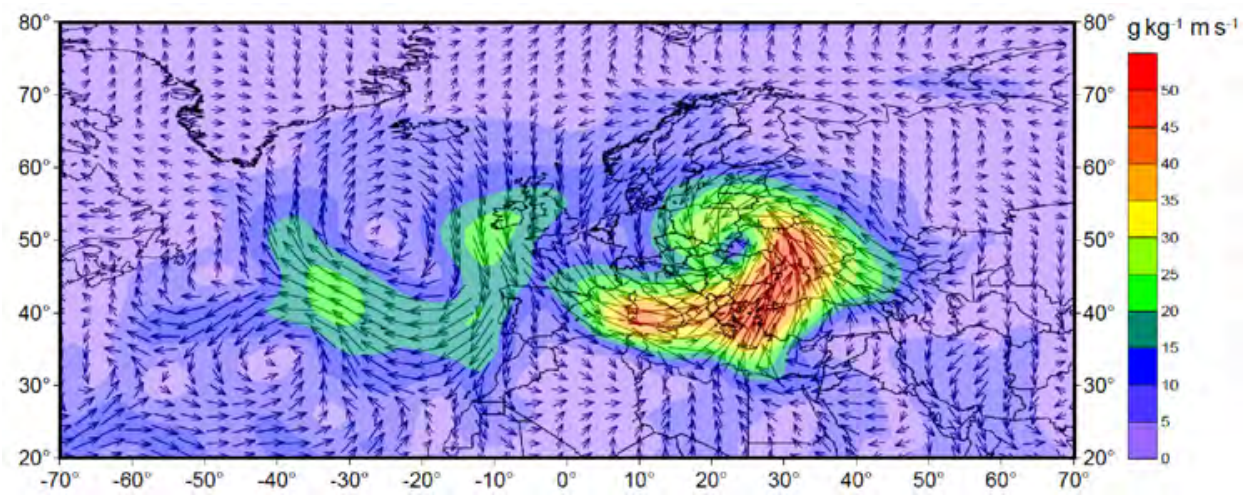

Rys. 7.10. Anomalie strumieni wilgoci uśrednione w terminach kiedy niże $M E C$ wystąpiły na opadotwórczym odcinku trajektorii E w okresie 1958-2008. Objaśnienia procedury liczenia anomalii jak na rys. 7.9

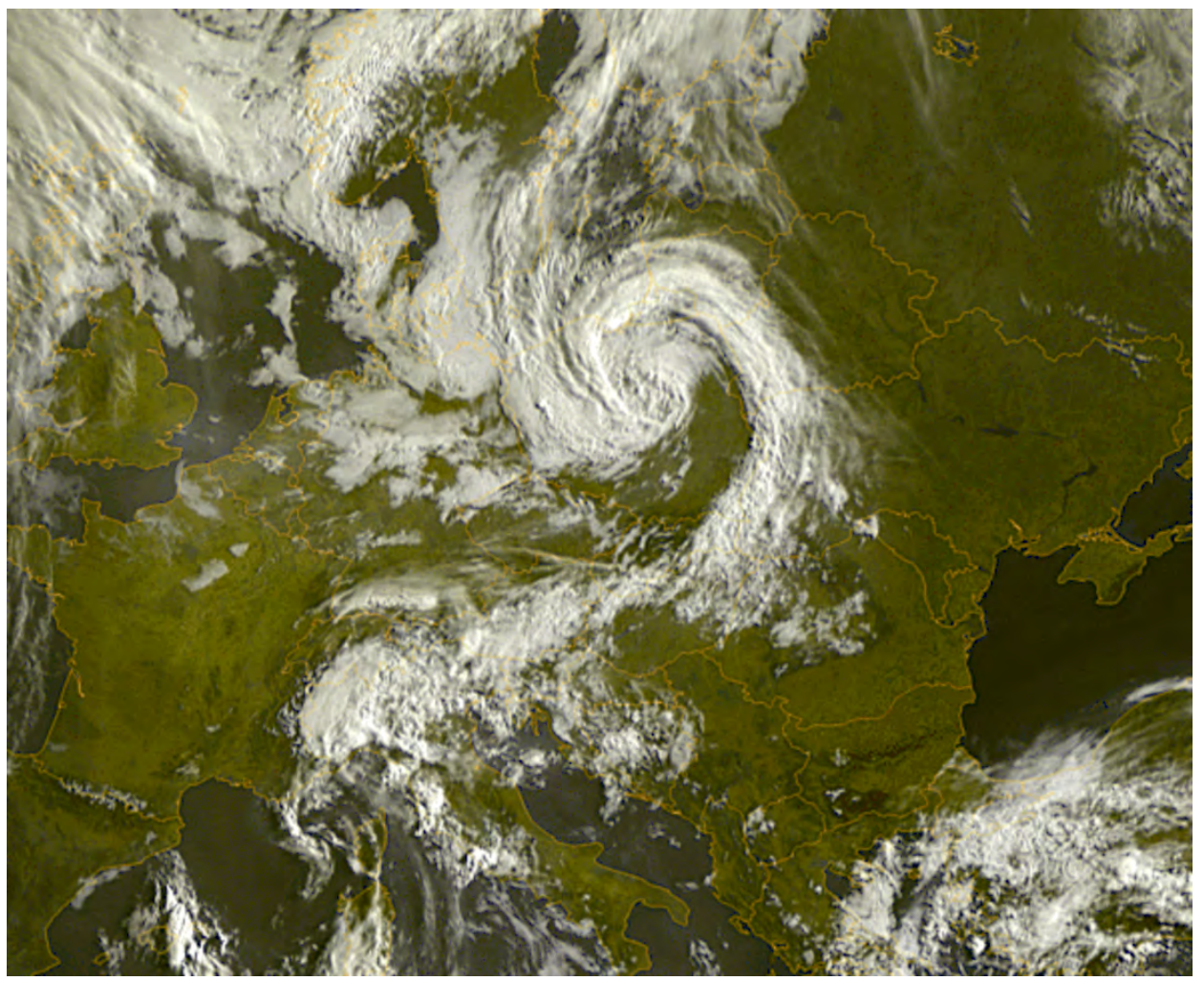

Rys. 7.11. Zachmurzenie związane z niżem MEC nad Polską (wg zbiorów Katedry Klimatologii UŚ) 
O nadwyżkach wilgoci w atmosferze nad Środkowo-Wschodnią Europą decyduje jednak przede wszystkim konwergencja strumieni wilgoci, która posiada swe maksimum we wschodniej Polsce oraz na wschód od granic kraju - nad Ukrainą i Białorusią (rys. 7.12). Można także zauważyć, że źródłem zasilania strumieni wilgoci nad Europą jest cały basen Morza Śródziemnego, zwłaszcza jego wschodnia część, nad którym ma miejsce dywergencja strumieni wilgoci.

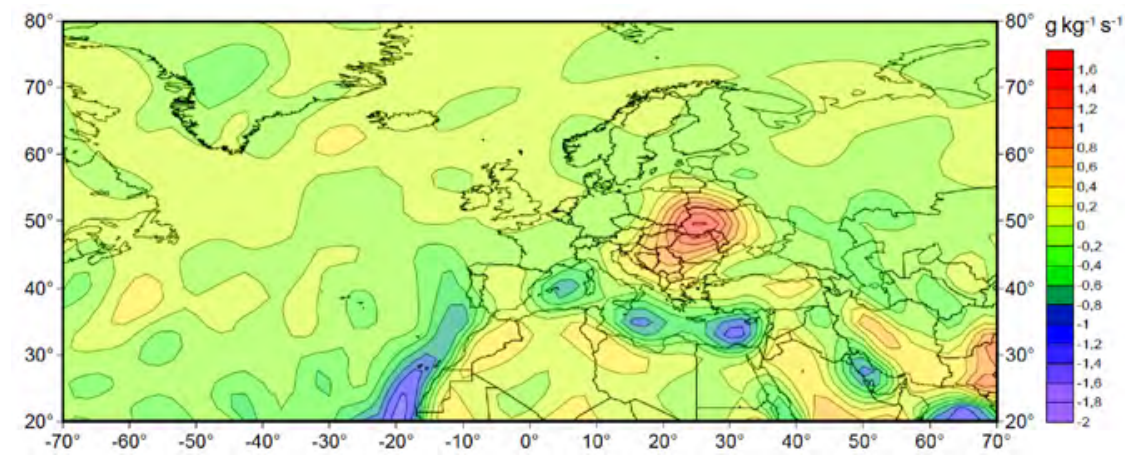

Rys. 7.12. Konwergencja strumieni wilgoci $\left[\times 10^{-4} \mathrm{~g} \mathrm{~kg}^{-1} \mathrm{~s}^{-1}\right]$ uśredniona w terminach kiedy niże $M E C$ występowały na opadotwórczym odcinku trajektorii $\mathrm{E}$ w okresie 1958-2008

\section{Niże MEC, pole temperatury w Europie i nad północnym Atlantykiem oraz opady w Polsce}

Rozkład anomalii PW nad Europą wykazuje ścisły związek z polem anomalii temperatury; największe nadwyżki wilgoci atmosferycznej pokrywają się z obszarami ciepłymi, a depresje wilgoci leżą w obszarach chłodu.

Na rys. 7.13 przedstawiono średnie izanomale temperatury powietrza odpowiadające niżom MEC na ich wschodnim szlaku. Maksimum dodatnich anomalii temperatury jest umiejscowione nad Ukrainą i Turcją, tj. w przybliżeniu zgodnie z występowaniem największych nadwyżek PW. Ujemne anomalie temperatury nad Francją, Szwajcarią i Niemcami stanowią dopełnienie tego dipolu termicznego, w którym poziomy gradient temperatury przekracza $7^{\circ} \mathrm{C}$.

Analogiczne związki pola anomalii PW i temperatury występują przy niżach MEC na pozostałych szlakach ich ruchu. Niżom na szlaku zachodnim (W) odpowiada gradient temperatury (różnica Тzach - $\mathrm{Twsch}_{\mathrm{ws}}-5,5^{\circ} \mathrm{C}$, niżom na szlaku C - gradient $-5,3^{\circ} \mathrm{C}$, a niżom, które występują na torze $\mathrm{S}$ - gradient 
$-3,9^{\circ} \mathrm{C}$ (tab. 7.6). $M E C$ pojawiają się w Europie Środkowo-Wschodniej w różnych porach roku, w związku z czym temperatura panująca w dniach ich występowania jest silnie zróżnicowana. Po wschodniej stronie torów niżowych współwystępujące z niżami $M E C$ wartości temperatury zawierały się w przedziale od -6 do $+26^{\circ} \mathrm{C}$, po zachodniej stronie - od -10 do $+15^{\circ} \mathrm{C}$. Rozkład wartości temperatury (rys. 7.14) uwidacznia tendencję, według której w niżach $M E C$ temperatura wzrasta z zachodu na wschód.

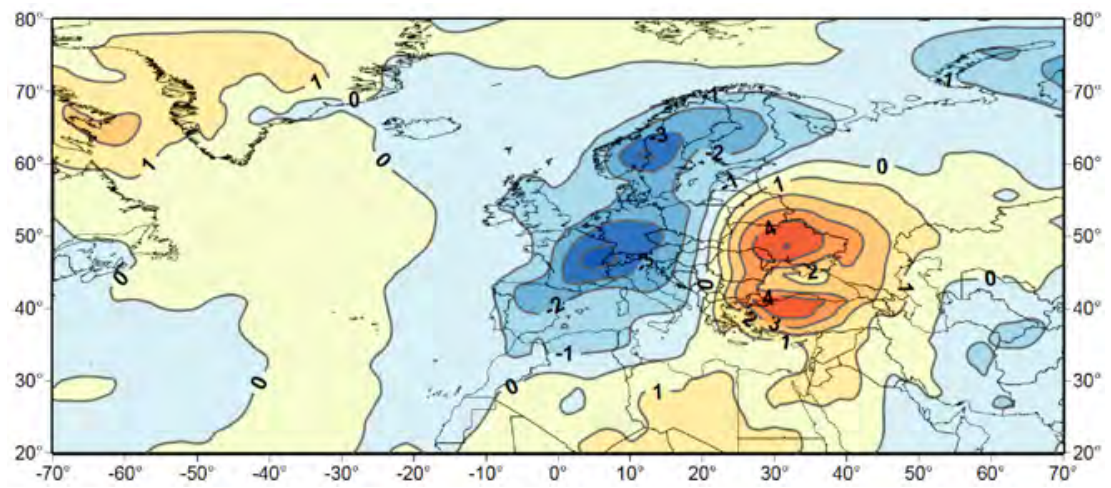

Rys. 7.13. Anomalie temperatury powietrza [ ${ }^{\circ} \mathrm{C}$ ] na wys. $2 \mathrm{~m}$ npt. uśrednione w terminach kiedy $M E C$ występowały na opadotwórczym odcinku trajektorii $\mathrm{E}$ w okresie 1958-2008. Objaśnienia procedury liczenia anomalii jak na rys. 7.9

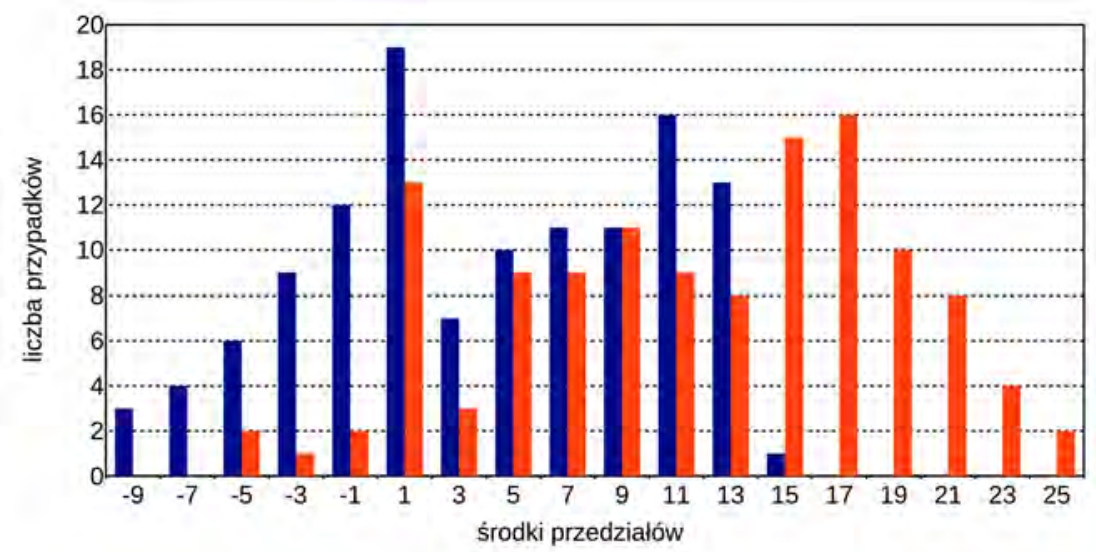

Rys. 7.14. Rozkłady częstości średniej temperatury w zachodniej (niebieski) i wschodniej Europie (czerwony) w okresie występowania MEC na opadotwórczym odcinku toru E. Przedziały o rozpiętości $2{ }^{\circ} \mathrm{C}$. Sektory, w granicach których uśredniono wartości temperatury jak na rys. 7.15 
Bardziej jednoznaczny obraz tej tendencji zawierają rozkłady anomalii temperatury, występującej po zachodniej i wschodniej stronie torów ruchu MEC (rys. 7.15-7.18). Na zachodzie dominują wyraźnie anomalie ujemne, na wschodzie - dodatnie. Średnie anomalie termiczne w zachodniej Europie, w centrum obszaru chłodu ${ }^{8}$, wahają się (w zależności od toru przemieszczania się niżu) od $-1,9$ do $-3,4^{\circ} \mathrm{C}$. Na wschodzie Europy, w obszarze najcieplejszym, wynoszą od $2^{\circ} \mathrm{C}$ do $3,7^{\circ} \mathrm{C}$ (tab. 7.6).

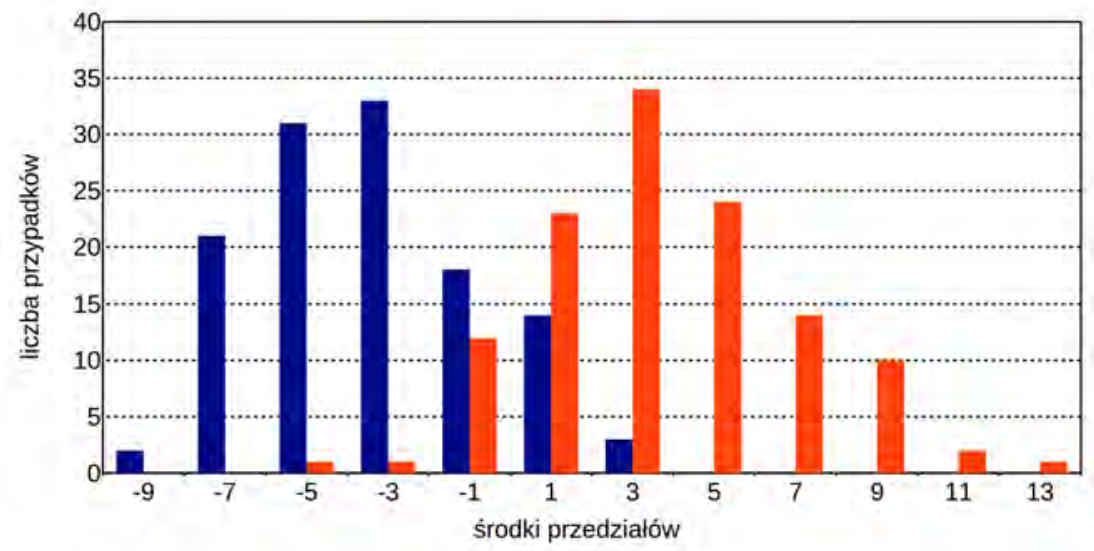

Rys. 7.15. Rozkłady anomalii średniej obszarowej temperatury na wys. $2 \mathrm{~m}$ n.p.t. w gridzie $2^{\circ}-14^{\circ} \mathrm{E} ; 43^{\circ}-52^{\circ} \mathrm{N}$ (Tzach - niebieski) oraz gridzie $27^{\circ}-37^{\circ} \mathrm{E} ; 4^{\circ}-52^{\circ} \mathrm{N}$ (Twsch - czerwony) w terminach kiedy MEC wystąpily na opadotwórczym odcinku trajektorii E w okresie 1958-2008. Wyeliminowano cykl roczny z serii temperatury.

Przedziały o rozpiętości $2^{\circ} \mathrm{C}$

Rozkłady anomalii termicznych (rys. 7.15-7.18) wykazują nieco większą zmienność temperatury po wschodniej stronie szlaków niżowych. Obok dominujących wartości dodatnich, dość często zdarzają się tam także ujemne anomalie temperatury. Występują także bardzo znaczne dodatnie anomalie, sięgające kilkunastu stopni (jak np. przy niżach na szlaku E i C). W rezultacie empiryczne rozkłady częstości tych anomalii są bardziej spłaszczone od rozkładów, charakteryzujących anomalie, występujące po zachodniej stronie szlaków niżowych. Adwekcje chłodu po zachodniej stronie niżów kształtują spadki temperatury na ogół nie sięgające 10 stopni, ale w ogromnej większości przypadków niżom $M E C$ towarzyszą ujemne anomalie termiczne w zachodniej

8 Określenia „obszar chłodu”, a także „obszar najcieplejszy” oznaczają tu położenie największych bezwzględnych odchyleń temperatury od jej średniego cyklu rocznego i nie odnoszą się do umiejscowienia najniższych bądź najwyższych wartości temperatury. 
Europie. Jest to wspomniana na wstępie tego rozdziału „kropla chłodu” - charakterystyczny czynnik i składnik cyklonalnej cyrkulacji niżów śródziemnomorskich.

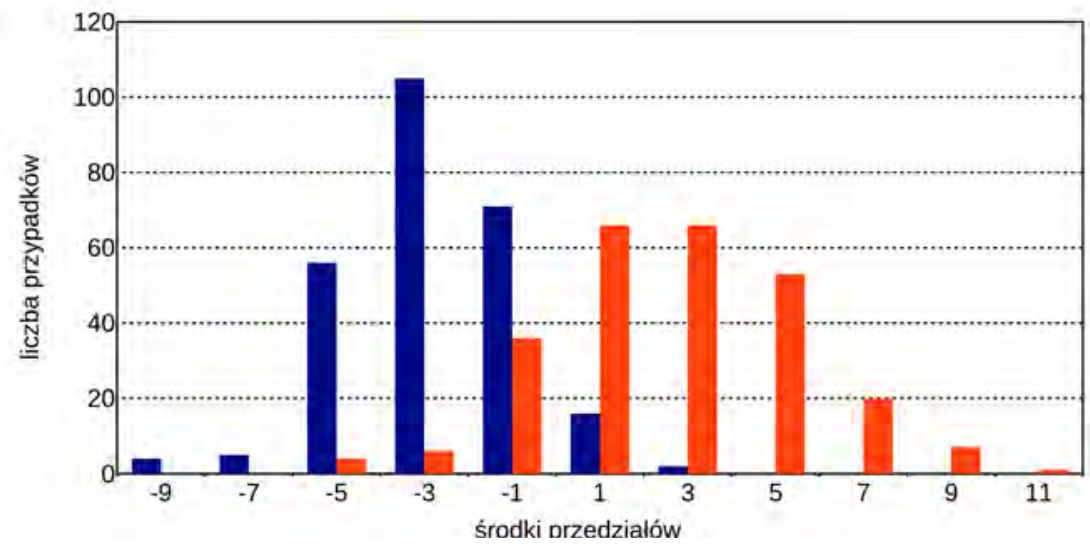

Rys. 7.16. Rozkłady anomalii średniej obszarowej temperatury na wys. $2 \mathrm{~m}$ n.p.t. w gridzie $5^{\circ} \mathrm{W}-10^{\circ} \mathrm{E} ; 40^{\circ}-50^{\circ} \mathrm{N}$ (Tzach - niebieski) oraz gridzie $22^{\circ}-31^{\circ} \mathrm{E} ; 41^{\circ}-52^{\circ} \mathrm{N}$ (Twsch - czerwony) w terminach kiedy MEC wystąpiły na opadotwórczym odcinku trajektorii C w okresie 1958-2008. Dalsze objaśnienia jak na rys. 7.15

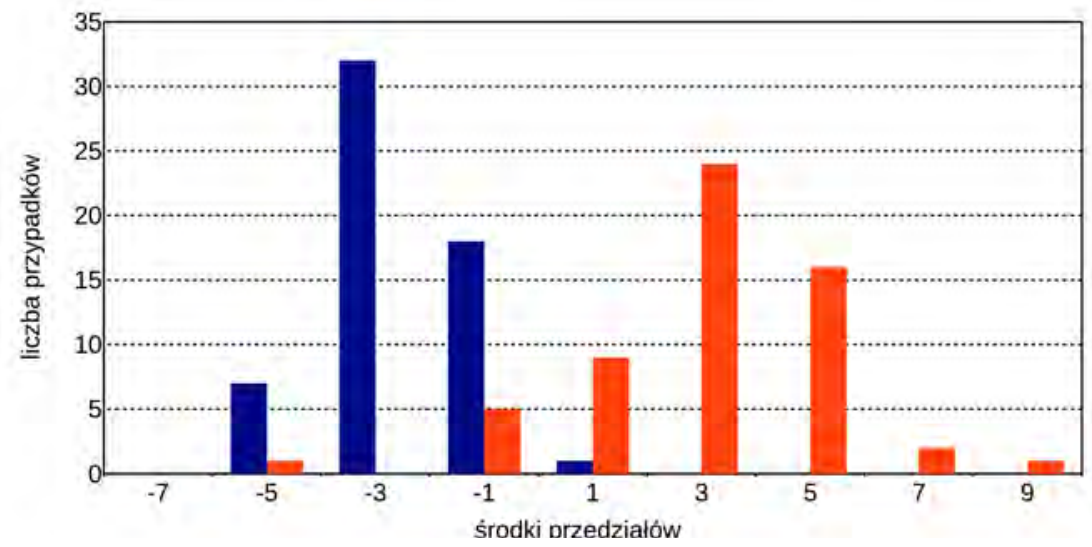

Rys. 7.17. Rozkłady anomalii średniej obszarowej temperatury na wys. $2 \mathrm{~m}$ n.p.t. w gridzie $10^{\circ} \mathrm{W}-0^{\circ} \mathrm{E} ; 35^{\circ}-45^{\circ} \mathrm{N}$ (TzACH - niebieski) oraz gridzie $13^{\circ}-25^{\circ} \mathrm{E} ; 48^{\circ}-55^{\circ} \mathrm{N}$ (Twsch - czerwony) w terminach kiedy MEC wystąpiły na opadotwórczym odcinku trajektorii W w okresie 1958-2008. Dalsze objaśnienia jak na rys. 7.15

Kontrasty termiczne, które towarzyszą niżom $M E C$ oddziałują na ich aktywność, a więc zarazem także na wysokość opadów atmosferycznych z nimi związanych. Analizując serie opadów MCP w Polsce oraz temperaturę 
$\mathrm{w}$ dniach ich występowania znaleziono istotne korelacje między sumami dobowymi $M C P$ i temperaturą, szczególnie temperaturą, panującą po zachodniej stronie szlaków niżowych. Niższej temperaturze w zachodniej Europie odpowiadają większe opady $M C P$ w Polsce. Dotyczy to opadów, związanych z niżami na szlakach E, C i S. Współczynnik korelacji prostej między opadami w Polsce, przynoszonymi przez niże na szlaku E i anomaliami temperatury panującej nad obszarem środkowych i zachodnich Niemiec wynosi $-0,25$. Po wyeliminowaniu wpływu zawartości wilgoci na opady, korelację cząstkową wyraża współczynnik -0,42, bliski korelacji opadów i zawartości wilgoci w atmosferze (odpowiednio: tab. 7.6 i tab. 7.4).

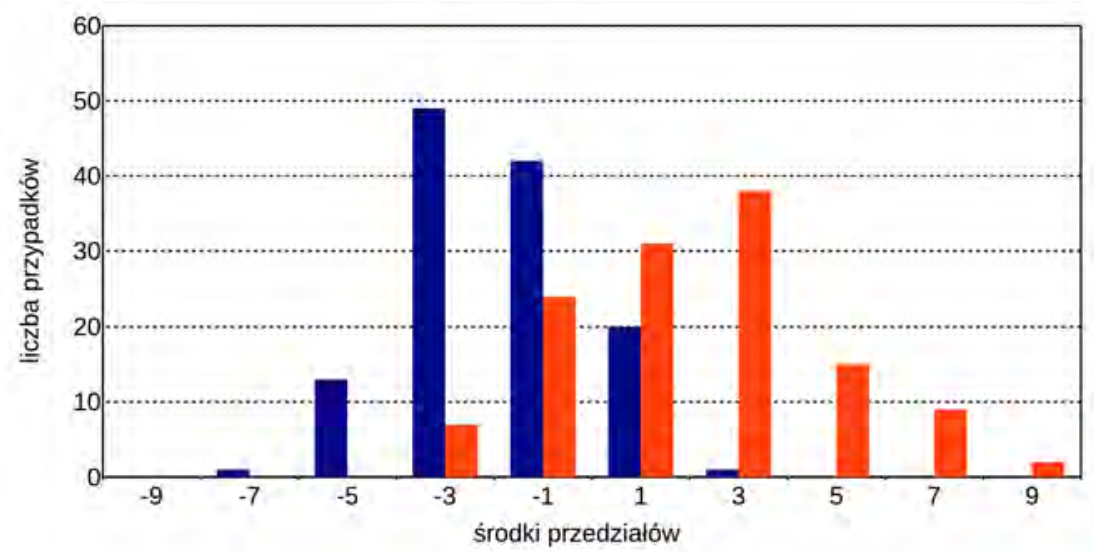

Rys. 7.18. Rozkłady anomalii średniej obszarowej temperatury na wys. $2 \mathrm{~m}$ n.p.t. w gridzie $4^{\circ} \mathrm{W}-10^{\circ} \mathrm{E} ; 41^{\circ}-52^{\circ} \mathrm{N}$ (Tzach - niebieski) oraz gridzie $21^{\circ}-33^{\circ} \mathrm{E} ; 38^{\circ}-49^{\circ} \mathrm{N}$ (Twsch - czerwony) w terminach kiedy MEC wystąpiły na opadotwórczym odcinku trajektorii S w okresie 1958-2008. Dalsze objaśnienia jak na rys. 7.15

Z kolei opady, związane z niżami na szlaku W są skorelowane z anomaliami temperatury nad Polską i Białorusią (tab. 7.6); korelacja jest negatywna, co oznaczać może, że przy adwekcji ciepłych mas powietrza opady nie są zbyt intensywne, bo w tych warunkach chwiejność konwekcyjna zanika. Warto jeszcze dodać, że, jak już wykazano, opady po wschodniej stronie torów niżowych są w ogóle niewielkie. Zanikające opady na wschodnich peryferiach niżów mogą oznaczać rozpogodzenie, a zarazem insolację i wzrost temperatury.

Korelacja opadów MCP i różnicy temperatur między zachodnimi i wschodnimi częściami niżów $M E C$, z jednym wyjątkiem, nie jest znacząca. Zamieszczone w tab. 7.6 współczynniki korelacji sugerują, iż wysokość opadów związanych z $M E C$ podlega przede wszystkim wpływowi rozwijającej się adwekcji (i/lub obecności) chłodnego powietrza na zachodnich peryferiach ni- 
żów. Wszystkie zidentyfikowane opady $M C P$ w Polsce są jednak dość słabo skorelowane z temperaturą w zachodniej Europie; współczynnik korelacji między dobowymi sumami MCP i anomaliami temperatury, występującymi po zachodniej stronie szlaków niżowych wynosi $-0,20$. Według równania regresji do wzrostu średniego opadu MCP o $1 \mathrm{~mm}$ przyczynia się zmiana anomalii temperatury sięgająca $2,7^{\circ} \mathrm{C}$ (rys. 7.19). Opady $M C P$ wykazują słabą korelację z różnicą temperatury między zachodnimi i wschodnimi peryferiami niżów MEC. Współczynnik korelacji wynosi -0,14. Wzrost $M C P$ o $1 \mathrm{~mm}$ skorelowany jest z przyrostem tej różnicy temperatur o $6,2^{\circ} \mathrm{C}$ (rys. 7.20).

Tab. 7.6. Średnie anomalie temperatury w obszarach położonych na zachód (TzACH) i na wschód (Twsch) od szlaków niżów $M E C$, ich różnice (TzACH-Twsch) $\left[{ }^{\circ} \mathrm{C}\right]$ oraz współczynniki korelacji (r) wysokości opadów $M C P$ w Polsce z anomaliami temperaturami TzACH, Twsch i różnicą TzACH-Twsch.

Zaznaczono współczynniki istotne na poz. 0,05

\begin{tabular}{ccccc}
\hline Szlak niżu & $\mathbf{W}$ & $\mathbf{C}$ & $\mathbf{S}$ & $\mathbf{E}$ \\
\hline Położ. (ZACH) & $10^{\circ} \mathrm{W}-0^{\circ} \mathrm{E}$ & $5-10^{\circ} \mathrm{E}$ & $4^{\circ} \mathrm{W}-10^{\circ} \mathrm{E}$ & $2-14^{\circ} \mathrm{E}$ \\
Średnia TzACH & $35-45^{\circ} \mathrm{N}$ & $40-50^{\circ} \mathrm{N}$ & $41^{\circ}-52^{\circ} \mathrm{N}$ & $43-52^{\circ} \mathrm{N}$ \\
$\mathbf{r}$ & $-2,49$ & $-2,76$ & $-1,92$ & $-3,36$ \\
r* & 0,00 & $-0,13$ & $-0,14$ & $-0,25$ \\
\hline \multirow{2}{*}{ Położ. (WSCH) } & $-0,04$ & $-0,16$ & $-0,25$ & $-0,42$ \\
Średnia Twsch & $13-25^{\circ} \mathrm{E}$ & $22-31^{\circ} \mathrm{E}$ & $21-33^{\circ} \mathrm{E}$ & $27-37^{\circ} \mathrm{E}$ \\
r & $48-55^{\circ} \mathrm{N}$ & $41-52^{\circ} \mathrm{N}$ & $38-49^{\circ} \mathrm{N}$ & $45-52^{\circ} \mathrm{N}$ \\
r* & 3,03 & 2,58 & 2,02 & 3,71 \\
\hline Różnica TzACH-TwsCH & $-0,20$ & 0,04 & 0,05 & $-0,06$ \\
r & $-0,38$ & $-0,15$ & $-0,07$ & $-0,10$ \\
\hline r* & $-5,52$ & $-5,34$ & $-3,94$ & $-7,07$ \\
& 0,19 & $-0,11$ & $-0,15$ & $-0,11$ \\
\hline
\end{tabular}

r* - korelacja cząstkowa - bez udziału PW.

Okazuje się, że kontrasty termiczne w niżach $M E C$ mają pewne znaczenie dla kształtowania się wysokości opadów MCP. W szczególności do wzrostu opadów przyczynia się ujemna anomalia temperatury, występująca po zachodniej stronie niżów. Owa „kropla chłodu”, podobnie jak zasoby wilgoci w atmosferze („plama wilgoci”), spełnia rolę składnika systemu niżowego, którego obecność warunkuje powstawanie opadów atmosferycznych $M C P$, ale nie wpływa bezwzględnie (a przynajmniej słabo wpływa) na ich wysokość. 


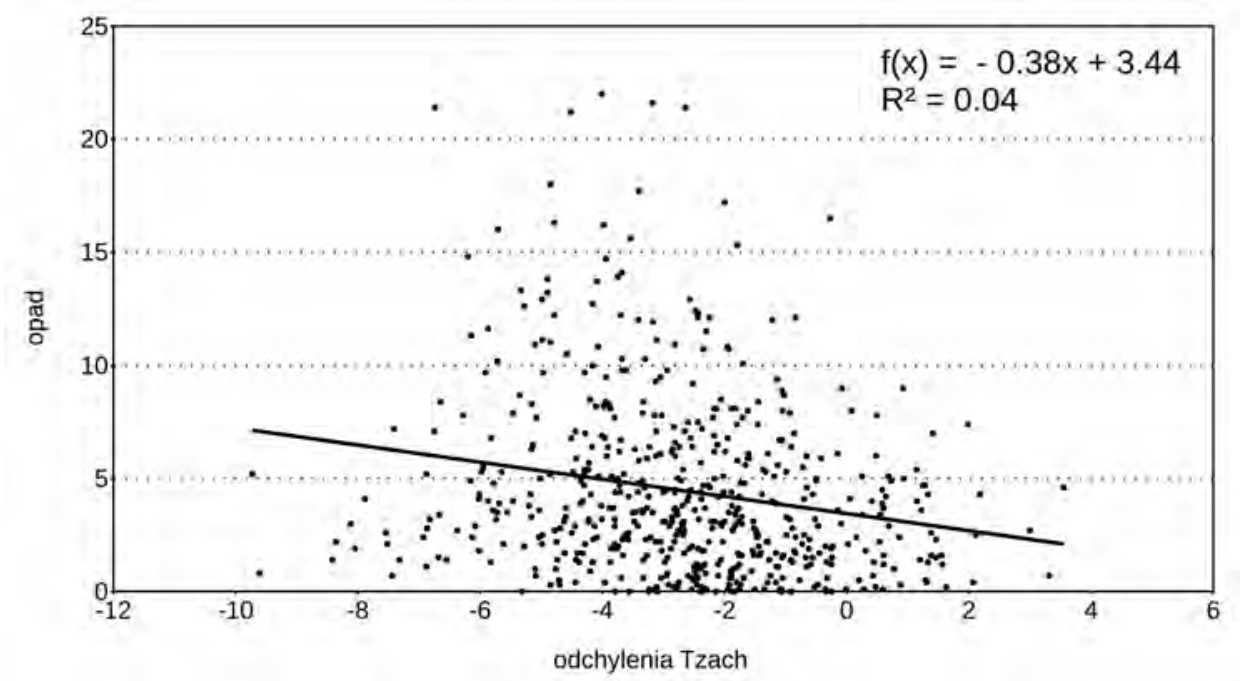

Rys. 7.19. Średni opad MCP w Polsce [mm] versus odchylenia temperatury na zachodzie Europy [Tzach, ${ }^{\circ} \mathrm{C}$ ]. Przedstawiono odchylenia temperatury od cyklu rocznego w terminach kiedy niże $M E C$ usytuowane były na opadotwórczych odcinkach

trajektorii E, C, W oraz S w okresie 1958-2008. Sektory Europy Zachodniej jak na rys. 7.15-7.18. Wartości MCP uśredniono dla obszaru Polski. Przedstawiono linię regresji wraz z równaniem i współczynnikiem determinacji $\left(\mathrm{R}^{2}\right)$

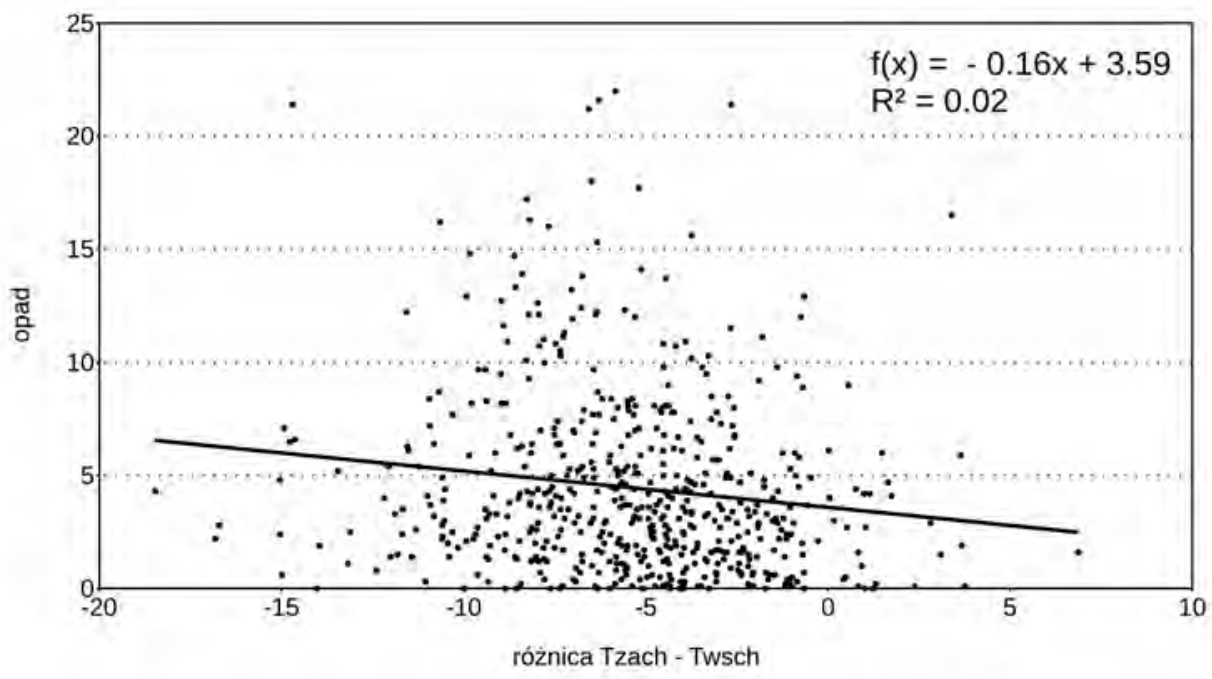

Rys. 7.20. Średni opad $M C P$ w Polsce [mm] versus różnice temperatury po zachodniej i wschodniej stronie szlaków niżowych [ $\left.{ }^{\circ} \mathrm{C}\right]$ (Tzach-Twsch).

Dalsze objaśnienia jak na rys. 7.19 


\section{Wnioski}

Pod wpływem niżów śródziemnomorskich zawartość wilgoci w atmosferze nad Polską wzrasta średnio o około 15\%; największy przyrost PW powodują niże wędrujące szlakiem zachodnim (22\%), najmniejszy - niże ze szlaku wschodniego (5\%).

Dobowe sumy opadów związanych z niżami MEC stanowią średnio od 11\% (opady związane z zachodnim szlakiem) do 37\% (opady niżów ze szlaku wschodniego) średniej zawartości wilgoci $w$ atmosferze. Skrajnie wysokie opady MCP stanowią jednakże wielokrotność słupa wilgoci atmosferycznej - mogą przewyższać go nawet 8-9 razy. Wysokość ekstremalnych opadów wykazuje słabą tendencję rosnącą w zależności od aktualnych zasobów PW. Wszystkie zidentyfikowane opady MCP wykazują istotną, ale niezbyt silną korelację z zawartością wilgoci. Zmiany zawartości wilgoci wyjaśniają jedynie $10 \%$ zmienności sum MCP.

MEC sterują napływem wilgoci znad Morza Śródziemnego i formują „plamę” wilgoci, zlokalizowaną nad Polską i na wschód od jej obszaru wskutek mającej tam miejsce konwergencji strumieni wilgoci.

Niżom MEC towarzyszy zarazem charakterystyczne zróżnicowanie temperatur nad Europą; średnie wartości różnic temperatury w przekroju równoleżnikowym niżów wynoszą około $7^{\circ} \mathrm{C}$. Temperatura przyziemnych warstw powietrza wzrasta z zachodu na wschód.

Wysokość opadów pochodzenia śródziemnomorskiego w Polsce wykazuje słabe korelacje $\mathrm{z}$ intensywnością adwekcji chłodu, tj. $\mathrm{z}$ ujemnymi anomaliami temperatury na zachodnich peryferiach $M E C$.

Degirmendžić J., Kożuchowski K., 2015b, The Mediterranean cyclones, precipitable water and precipitation in Poland. Geographia Polonica (w druku);

Kożuchowski K., 2015a, Obfitość opadów w Polsce w przebiegu rocznym. Przegląd Geofizyczny, t. LX, z. 1-2, s. 27-38;

Kożuchowski K., 2015b, Zawartość wilgoci w atmosferze i opady w Polsce. Przegląd Geofizyczny (w druku) 



\section{Rozdział 8 Tendencje zmian wieloletnich}

\section{Ocieplenie, cyrkulacja atmosferyczna i opady od połowy XX wieku}

Dominującą tendencją klimatyczną ubiegłego półwiecza było ocieplenie, które w Polsce osiągnęło rozmiary przekraczające średnią wielkość przyrostu temperatury w skali globalnej. Od połowy XX w. średnie temperatury roczne w Polsce podniosły się o około $1^{\circ} \mathrm{C}$, w końcu zimy, a także w marcu i w sierpniu przyrosty temperatury przekroczyły nawet $2^{\circ} \mathrm{C}$ (Michalska, 2011).

Ocieplenie powiązane jest ze zmianami pozostałych komponentów systemu klimatycznego, w tym z opadami i cyrkulacja atmosferyczną. Związki te są jednak złożone i nie zawsze jednoznaczne. W odniesieniu do opadów atmosferycznych oraz tzw. zjawisk ekstremalnych (do których można także zaliczyć niże śródziemnomorskie, przynoszące nawalne opady i powodzie) dominuje pogląd, że wraz z postępującym ociepleniem w Europie Środkowej zmniejszą się sumy opadów letnich, wzrosną opady zimowe, a także częstość i intensywność opadów ekstremalnych (Kundzewicz i in., 2006). Przewiduje się, między innymi, że „opady będą skoncentrowane w epizodach deszczów o dużej intensywności, rozdzielonych dłuższymi okresami posusznymi” (Dankers i Hiederer, 2008).

Także Ulbrich i in. (2003) wskazali na związany ze zmianą klimatu wzrost częstości opadów intensywnych w Europie, przy równoczesnym spadku całkowitych sum opadów letnich. Autorzy ci podkreślili ponadto związek liczby dni z intensywnymi opadami i południkowych typów sytuacji synoptycznych, kształtujących baryczną zatokę w środkowej i górnej troposferze nad Europą Zachodnią i Środkową. Takie sytuacje powodują tworzenie się dolnych niżów wędrujących szlakiem Vb. Powstaje pytanie o realizację scenariuszy klimatycznych, w tym m.in. o dotychczas obserwowane tendencje częstości występowania niżów „Vb”, a także o sprzyjające im warunki makrocyrkulacyjne. 
Roczne liczby MEC wykazują znaczną zmienność; w niektórych latach zarejestrowano zaledwie 3 niże (np. w r. 1976, 1990, 1998), w innych - głównie w pierwszej połowie analizowanego okresu (r. 1963, 1975) - aż 13 niżów MEC. Mała częstość występowania niżów w Europie Środkowo-Wschodniej charakteryzowała lata 1980. W tym czasie obecność niżów nad Zatoką Genueńską, głównym obszarem cyklogenezy śródziemnomorskiej, była także wyjątkowo rzadka (Bartholy i in., 2009), a głębokie niże wędrujące szlakiem T7 (odpowiednik szlaku Vb) w ciągu lat 1980-1987 w ogóle nie występowały (cyt. za Bielec-Bąkowska, 2010).

Druga połowa XX wieku była okresem postępującego rozwoju, a następnie dość gwałtownego „załamania się” frekwencji południkowych form cyrkulacji atmosferycznej. Pod koniec wieku zmalała szczególnie częstość makroformy E cyrkulacji (wg klasyfikacji Vangengeima-Girsa), kształtująca zatokę nad Europą Środkową (Sepp, 2011) (rys. 8.1). Wcześniej, mniej więcej do końca lat 1970., forma E wyróżniała się rosnącą frekwencją (Kożuchowski, 1993). Warto zauważyć, iż przebieg częstości pojawiania się południkowych makroform cyrkulacji pozostaje w sprzeczności z sugerowanym rozwojem sytuacji synoptycznych, sprzyjających zatoce nad Europą Zachodnią i Środkową. Taką zatokę reprezentuje makrotyp E, którego częstość, w ostatniej epoce cyrkulacyjnej, wykazuje wyraźną tendencję malejącą (rys. 8.1).

Syntetyczny obraz tendencji zmian opadów atmosferycznych w Europie stanowi zestawienie trendów sezonowych sum opadów, różniących się w charakterystyczny sposób na jej obszarze: północne obszary wyróżniają się rosnącymi opadami, na południu kontynentu - opady zmniejszają się (tab. 8.1). Owe zróżnicowanie znajduje także swoje odbicie na mapie zmian opadów w Polsce (rys. 8.2).

Na podstawie wyników różnych analiz można jednak przyjąć, że średnie opady w Polsce nie wykazywały od połowy XX wieku znaczących zmian. Według Miętusa (Projekt Klimat, 2009) średnie obszarowe sumy opadów w Polsce w okresie 1961-2009 „wykazują lekką tendencję spadkową”. Marosz i in. (2011) na przeważającej części obszaru Polski znaleźli malejące tendencje opadów rocznych, szczególnie silne na Dolnym Śląsku, gdzie w latach 1961-2008 opady zmniejszyły się o ponad $100 \mathrm{~mm}$. Czarnecka i NidzgorskaLencewicz (2012) nie stwierdziły istotnych zmian w opadach sezonowych i rocznych w Polsce w latach 1951-2010. Zauważono jedynie „niewielką tendencję do wzrostu opadów w sezonach wiosennym i jesiennym oraz malejący udział opadów letnich w sumie rocznej". Tendencji tej towarzyszyły, sygnalizowane także w niektórych innych pracach, przyrosty sum opadowych, obser- 
wowane w północnej części Polski, przy na ogół malejących opadach na południu kraju (rys. 8.2).

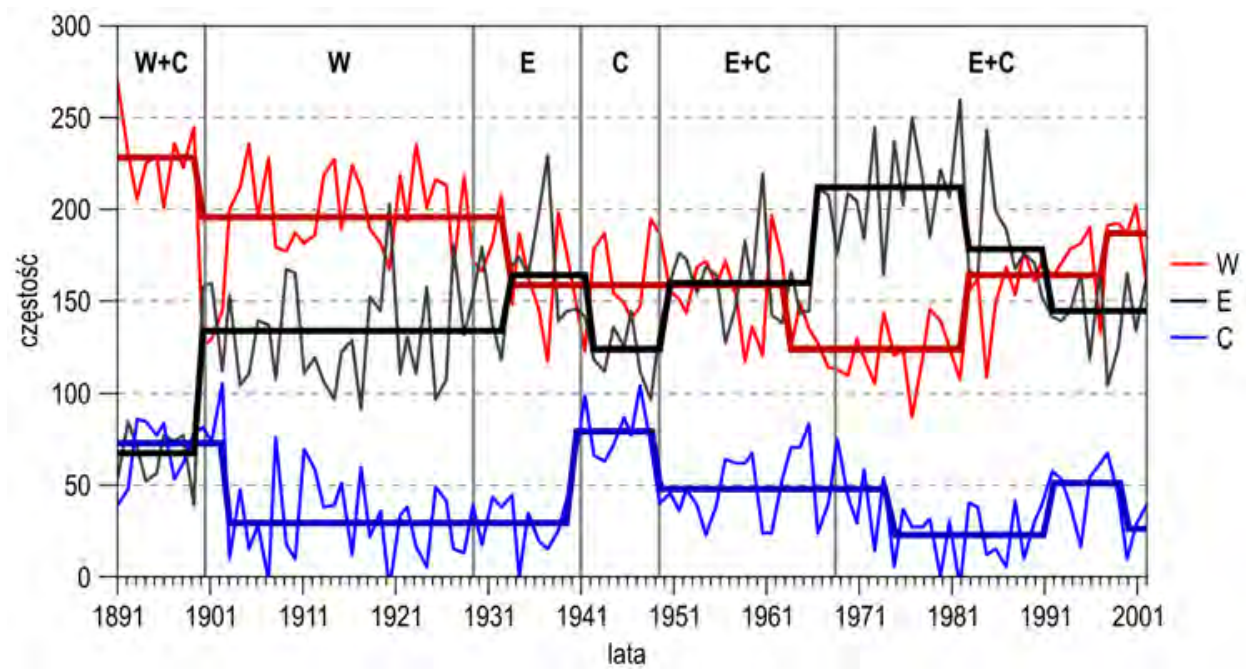

Rys. 8.1. Roczne częstości makroformy cyrkulacji W, E, C (wg Vangengeima-Girsa)

i epoki cyrkulacyjne od 1891 do 2001 roku. Dla zwiększenia czytelności wykresu wartość 50 dodano do częstości makroformy W oraz odjęto od częstości makroformy C (wg Sepp'a, 2011)

Tab. 8.1. Trendy sezonowych sum opadów w Europie w latach 1951-2010 [mm/10 lat] (wg Besselaar i in., 2012)

\begin{tabular}{lrrrr}
\hline Obszar & $\begin{array}{r}\text { Zima } \\
\text { (XII-II) }\end{array}$ & $\begin{array}{r}\text { Wiosna } \\
\text { (III-V) }\end{array}$ & $\begin{array}{r}\text { Lato } \\
\text { (VI-VIII) }\end{array}$ & $\begin{array}{r}\text { Jesień } \\
\text { (IX-XI) }\end{array}$ \\
\hline Europa Północna, $\varphi>48^{\circ} \mathrm{N}$ & 5,08 & 4,05 & $-0,99$ & 4,86 \\
Europa Południowa, $\varphi<48^{\circ} \mathrm{N}$ & $-5,33$ & $-0,53$ & $-2,03$ & 3,17 \\
\hline
\end{tabular}

Marosz i in. (2011) zauważyli natomiast „niemal w całym kraju” rosnącą tendencję liczby dni $z$ opadem. Tendencja ta rzutuje na zmianę obfitości opadów, która skutkiem tego wykazuje trend malejący. Jest on znaczący w sezonie letnim, a w górach charakteryzuje średnioroczną obfitość opadów (tab. 8.1). Obfitość opadów zmniejszała się zarówno w górach, co stwierdziła Żmudzka (2010) na przykładzie danych z Kasprowego Wierchu (1966-2006), jak i w południowo-zachodniej części Polski, „gdzie wyraźny wzrost liczby dni z opadem jest stowarzyszony ze spadkiem sum opadów..." (Marosz i in., 2011). Badania Wibig (2009) wykazały, że od połowy XX wieku wzrosła w Polsce częstość występowania opadów o niskich sumach dobowych, natomiast 
opady wysokie (na poziomie 5., 10. i 25. percentyla), jak również maksymalne sumy dobowe cechowała tendencja malejąca. Wniosek o zmniejszających się wysokościach maksimów opadowych w Polsce w latach 1951-2006 przedstawiła też Łupikasza (2010b), która wykazała ponadto, że w większości trendy te były stabilne w ciągu wielolecia. W opozycji do wniosku o malejącej obfitości opadów pozostają opinie, wskazujące na wzrastającą liczbę dni z wysokimi sumami opadów. W Projekcie Klimat (2010) stwierdzono m.in., że na przełomie XX i XXI stulecia wzrosła $\mathrm{w}$ Polsce częstość dni z opadem $>10 \mathrm{~mm}$ (wzrost do 4 dni/10 lat), dni z opadem $>30 \mathrm{~mm}$ (wzrost o 3 dni/10 lat) i z opadem ponad $50 \mathrm{~mm}$ (wzrost do 2 dni/10 lat). Według Lorenc i Oleckiej (2006), cały okres 1971-2002 charakteryzował się rosnącym trendem częstości dni z opadem $>10,>20$ i $>30 \mathrm{~mm}$, a okresy bezopadowe $\mathrm{w}$ tym czasie uległy skróceniu. Jednakże w pracy Cebulak i Pyrca (2006) przedstawiono znaczący wniosek o zmienności liczby dni z opadami $>100 \mathrm{~mm}$ w ciągu XX wieku (do 2005 r.). Częstość występowania tych wysokich opadów w dorzeczu górnej Wisły była szczególnie duża w latach 1960. i 1970., natomiast w l. 1980. i późniejszych - wyraźnie zmniejszyła się. Według badań ekstremalnych opadów w całej Polsce (48 stacji) większość ocen trendów opadowych wykazuje malejącą tendencję zmian wysokości i frekwencji maksymalnych opadów. Najsilniejsze negatywne trendy obserwowano w lecie i w zimie, szczególnie na południu kraju (Łupikasza, 2010b). Malejące trendy wskaźników maksymalnych opadów są pewną osobliwością południowej części Polski; w Niemczech jak i w Czechach dominują bowiem trendy rosnące (Łupikasza i in., 2011; Kysely, 2009).

Malejące trendy wartości zawartości wilgoci $w$ atmosferze $\mathrm{w}$ latach 1958-2005 stwierdzili Wibig i Siedlecki (2007). Autorzy ci wskazują, że nad kontynentami zawartość wilgoci w atmosferze podlega zarówno wpływom wilgotności podłoża atmosfery, jak i adwekcji wilgoci, zależnej od cyrkulacji atmosferycznej (Wibig, 2008). W Europie istnieją obszary charakteryzujące się zróżnicowanymi trendami PW - rosnące tendencje zaobserwowano m.in. na wschodzie i na północy kontynentu, malejące - przede wszystkim na południu Europy, w tym nad Polską.

Wyniki przytoczonych tu analiz nie są w pełni porównywalne, choćby ze względu na różne wykorzystane w nich serie pomiarowe opadów, a przy tym trendy w częstości występowania wysokich czy niskich opadów nie przesądzają o tendencji uśrednionej sumy dobowej, zwanej obfitością opadu. 


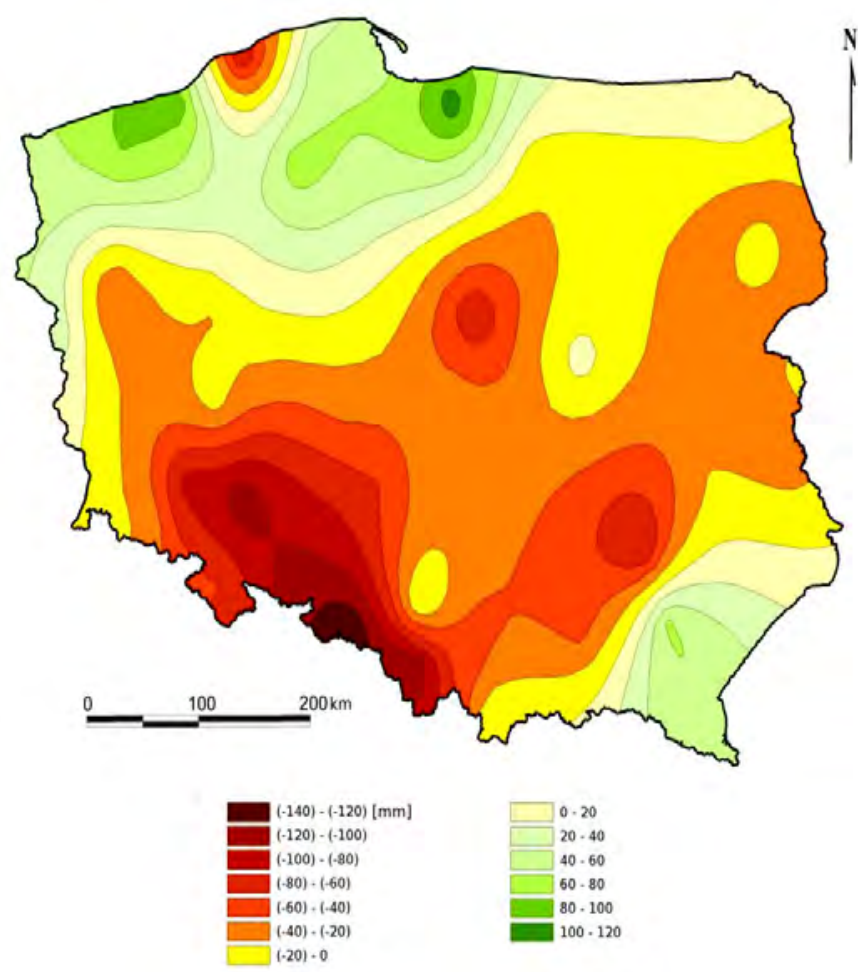

Rys. 8.2. Wielkość zmian rocznych sum opadów [mm] w Polsce w okresie 1961-2008 (wg Marosza i in., 2011)

\section{Cele, materiał i metody analizy}

Celem tej części opracowania jest określenie wieloletnich tendencji zmian częstości i aktywności występujących w badanym okresie niżów śródziemnomorskich MEC oraz opadów w Polsce, związanych z działalnością tych niżów. Wyniki wykonanych analiz statystycznych stanowić mogą przyczynek do weryfikacji hipotezy o rosnącej intensywności ekstremalnych zjawisk hydrometeorologicznych, towarzyszących współczesnym zmianom klimatycznym. Niże śródziemnomorskie tworzą niewątpliwie warunki sprzyjające takim skrajnym zjawiskom w Polsce, jak rozlewne i nawalne opady oraz wezbrania i powodzie. Weryfikacji poddano także hipotezę o związku powstających nad basenem Morza Śródziemnego i wędrujących szlakami nad Europą Środkowo-Wschodnią niżów z makroformami cyrkulacji atmosferycznej 


\section{w atlantycko-euroazjatyckim sektorze półkuli północnej. Potwierdze- nie tej hipotezy może stanowić wyjaśnienie obserwowanej zmienności występowania MEC.}

Wieloletnie zmiany MEC w okresie 1958-2008 opisano na podstawie ich rocznej i sezonowej częstości oraz średnich rocznych i sezonowych wartości, wyznaczonych na podstawie maksymalnej wirowości, największej spadkowej tendencji ciśnienia oraz minimalnego ciśnienia w centrum każdego niżu MEC. Te parametry wybrano spośród wszystkich terminów (maksymalny laplasjan, minimalne ciśnienie) oraz 6-godzinnych etapów (maksymalne pogłębianie) składających się na cykl życiowy niżu $M E C$. W ten sposób, poza frekwencją niżów, otrzymano charakterystyki zmian aktywności niżów w wieloleciu.

Trendy opadów MCP określono na podstawie średnich obszarowych sum opadów w dniach, w których opad na danej stacji związano z aktywnością niżu MEC (metoda najmniejszej ortodromy - zob. opis w rozdz. 3). Uwzględniono ponadto obfitość („wydajność”) tych opadów, tzn. średnie sumy przypadające na dzień z opadem. Te same charakterystyki zastosowano do oceny trendów zmian całkowitych opadów na obszarze Polski oraz w nizinnej i górskiej części kraju.

Zawartość wilgoci w atmosferze nad Polską $(P W)$ określono na podstawie danych reanaliz NCEP/NCAR (Kalnay i in., 1996). Wyznaczono średnie dobowe wartości PW dla każdego dnia w roku, a następnie obliczono względne odchylenia PW od średniej wieloletniej wartości PW w dniach występowania opadów $M C P(\Delta)$ (zob. rozdz. 3).

Obliczono współczynniki trendów liniowych dla średnich rocznych i średnich sezonowych (wg kalendarzowych pór roku) wartości łącznie 17 charakterystyk niżów $M E C$, opadów $M C P$ i opadów całkowitych w Polsce oraz zawartości wilgoci w atmosferze (PW). Istotność obserwowanych tendencji sprawdzono, stosując test Mann Kendalla i przyjmując poziom istotności $\alpha=0,05$.

Obliczono ponadto średnie wartości PW, odpowiadające działalności niżów $M E C$ na ich wyróżnionych szlakach, obfitość opadów $M C P$ oraz ilorazy wysokości dobowych opadów (DP) i odpowiadającej im zawartości wilgoci PW. Ilorazy DP/PW stanowią odpowiednik współczynnika efektywności układu opadotwórczego, który na przykładzie opadów w Kieleckiem badał Suligowski $(2004,2013)$. Przedstawiono także średnią zawartość wilgoci w atmosferze podczas występowania najwyższych dobowych opadów pochodzenia śródziemnomorskiego ( $M C P>90 \mathrm{~mm} /$ dobę) .

Wykorzystując tezę zakładającą występowanie cyklonów śródziemnomorskich na szlaku Vb w warunkach rozwoju południkowych form cyrkulacji V-G, 
sprawdzono zbieżność frekwencji $M E C$ na głównym obszarze ich cyklogenezy, tj. w basenie Morza Śródziemnego oraz na opadotwórczych odcinkach trajektorii w Europie Środkowo-Wschodniej i frekwencji makrotypów cyrkulacji południkowej E i C oraz makrotypu cyrkulacji strefowej W wg klasyfikacji Vangengeima-Girsa (V-G, Girs, 1971). Wykorzystano w tym celu katalog makrotypów cyrkulacji, opublikowany przez Dimitrieeva i Belyazo (2006). Obliczono też trendy wieloletnich zmian frekwencji makrotypów cyrkulacji V-G w celu porównania ich ze zmianami występowania niżów MEC.

\section{Liczba i cechy niżów śródziemnomorskich w okresie 1958-2008}

Pierwsze dwie, trzy dekady analizowanego okresu lat 1958-2008 wyróżniają się podwyższoną częstością występowania niżów $M E C$, zidentyfikowanych na opadotwórczych odcinkach ich torów, a także niżów $M E C_{0}$, obecnych nad basenem Morza Śródziemnego. Liczba niżów na opadotwórczych odcinkach $\left(M E C_{\mathrm{P}}\right)$ w latach 1958-1967 stanowiła 130\% „normy” wieloletniej, a niżów nad Morzem Śródziemnym - 121\% średniej wieloletniej. W ostatniej dekadzie (1998-2007) liczby te zmniejszyły się odpowiednio do 87 i $82 \%$ (tab. 8.2). Szczególnie „ostry” spadek dotyczył niżów, wędrujących torem wschodnim (E): ich liczba zmniejszyła się ponad 2,5-krotnie (od 167 do 63\% „normy”). Za to wzrosła nieco liczba niżów na szlaku W. Wobec niewielkiej częstości tej klasy niżów można jednak przyjąć wniosek, iż ogólna częstość występowania niżów $M E C$ w badanym okresie zmalała znacząco.

Malała całkowita liczba zidentyfikowanych niżów śródziemnomorskich, docierających do Europy Środkowo-Wschodniej w wieloleciu 1958-2008. Roczna liczba $M E C$ wykazuje istotny trend zniżkowy (rys. 8.3). Ich częstość zmalała o ponad połowę jej średniej wartości (6,9 niżów w roku, tab. 8.2). Ujemne, ale nieistotne trendy dotyczą częstości $M E C$ we wszystkich porach roku (tab. 8.3).

Niejednoznaczne, sezonowo zróżnicowane są tendencje zmian ciśnienia w niżach śródziemnomorskich (tab. 8.3). Znaczący okazuje się jedynie trend, który oznacza wzrost średniego ciśnienia w centrum niżów $M E C$ w sezonie zimowym. Słaby, nieistotny trend dodatni obserwuje się także na wiosnę oraz w serii wartości rocznych, ale latem i w jesieni - niże $M E C$ w ciągu wielolecia pogłębiały się. Tendencja zmian ciśnienia w niżach, charakteryzująca dynamikę cyklogenezy, wykazuje nie znaczące zmiany. Względnie wysoki, choć także 
nie istotny współczynnik trendu przypada na jesień, co świadczy, iż w tej porze roku nieco wzrosła dynamika niżów. W jesieni wzrastała także wirowość cyrkulacji w niżach. Można sądzić, że jesienne niże stały się bardziej aktywne, a ich liczba zmniejszała się nieznacznie, podczas gdy zimowe wykazywały coraz mniejszą częstość i aktywność.

Tab. 8.2. Częstości $M E C$ w latach 1958-2007. Średnie 10-letnie liczby dni w \% średniej 50-letniej oraz łączna średnia liczba dni z niżami $M E C$ w 50-leciu

\begin{tabular}{|c|c|c|c|c|c|c|}
\hline \multirow{2}{*}{ Okres } & \multicolumn{5}{|c|}{$\begin{array}{c}\text { Niże } \text { MEC }_{p} \\
\text { na opadotwórczych odcinkach toru [\%] }\end{array}$} & \multirow{2}{*}{$\begin{array}{c}\text { Niże } \text { MEC }_{0} \\
\text { nad basenem } \\
\text { M. Śródziemnegc } \\
{[\%]}\end{array}$} \\
\hline & $\mathbf{E}$ & C & W & $\mathbf{S}$ & Razem & \\
\hline 1958-1967 & 167 & 114 & 86 & 148 & 130 & 121 \\
\hline 1968-1977 & 88 & 110 & 27 & 128 & 101 & 116 \\
\hline 1978-1987 & 83 & 100 & 164 & 80 & 99 & 101 \\
\hline 1988-1997 & 100 & 83 & 86 & 68 & 83 & 79 \\
\hline 1998-2007 & 63 & 93 & 138 & 76 & 87 & 82 \\
\hline $\begin{array}{l}\text { Średnia roczna } \\
\text { liczba dni (1958-2007) }\end{array}$ & 2,4 & 5,1 & 1,1 & 2,5 & 11,1 & 6,9 \\
\hline
\end{tabular}

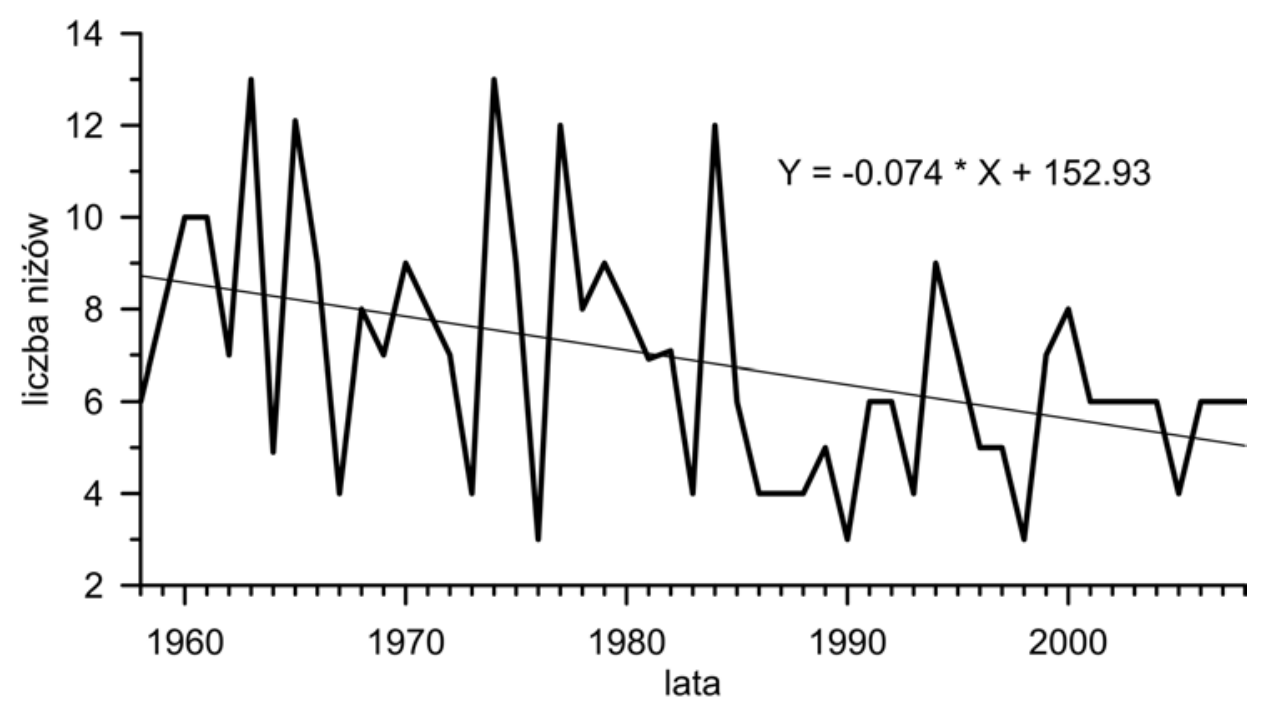

Rys. 8.3. Roczna liczba niżów śródziemnomorskich nad Europą Środkowo-Wschodnią w okresie 1958-2008 oraz trend liniowy MEC (wg Degirmendžića

i Kożuchowskiego, 2105b) 


\section{Zmiany opadów pochodzenia śródziemnomorskiego}

W latach 1958-2008 opady o genezie śródziemnomorskiej w Polsce wykazywały znaczną zmienność; ich uśrednione na obszarze kraju roczne sumy wahały się od 20 do ponad $150 \mathrm{~mm}$. W zmienności tej dominowała tendencja malejąca. „Nadwyżki” opadów MCP dominowały do 1981 roku, później przeważały ich „niedobory”. Trendy liniowe 51-letniej serii $M C P$ wykazują systematyczny spadek ich wysokości, zarówno w ciągu roku, jak i w porach roku, $\mathrm{z}$ wyjątkiem lata. Na obszarze górskim malejącym trendem charakteryzują się także opady w sezonie letnim (tab. 8.3).

W analizowanym okresie 1958-2008 roczne sumy MCP w Polsce zmniejszyły się o $29 \mathrm{~mm}$, co stanowi 43\% ich średniej wieloletniej wysokości. W górach spadek ten wyniósł $63 \mathrm{~mm}(56 \%)$. Są to statystycznie istotne $(\alpha=0,05)$ trendy malejące. Istotny jest także malejący trend opadów $M C P \mathrm{w}$ zimie na obszarze kraju (tab. 8.3).

Średnie roczne sumy opadów pochodzenia śródziemnomorskiego na obszarze Polski $\mathrm{w}$ analizowanym wieloleciu zmniejszyły się, podobnie jak częstość występowania niżów $M E C$. Zmalały znacząco opady $M C P$ w sezonie zimowym, co daje się połączyć z malejącą głębokością niżów $M E C$ w tym sezonie (tab. 8.3). Szczególnie wyraźnie zmniejszyły się opady MCP w górach; istotne malejące trendy wykazały opady wiosenne, jesienne i zimowe, a także roczne sumy $M C P$. Na nizinach zmiany te okazały się nie istotne, z wyjątkiem $M C P$ w okresie zimy, które zmalały znacząco, zgodnie z malejącą częstością i głębokością $M E C$.

Ujemne trendy opadów MCP odpowiadają malejącej tendencji częstości występowania cyklonów śródziemnomorskich; na podstawie trendu liniowego częstości układów MEC można stwierdzić, iż w ciągu wielolecia 1958-2008 liczba cyklonów śródziemnomorskich zmniejszyła się od 8,7 do $5 \mathrm{MEC/rok}$ (tab. 8.3). Największym spadkiem częstości wyróżniały się cyklony MEC na wiosnę (spadek 1,3 MEC), w sezonie letnim ich liczba zmniejszyła się zaledwie o 0,43 MEC (MCP w tym sezonie pozostały praktycznie bez zmian). Dość znacznie zmniejszyła się liczba cyklonów śródziemnomorskich w zimie $(1,13)$. W tym też sezonie odnotowano istotny trend malejący opadów $M C P$.

Porównanie przebiegu $M C P$ na tle całkowitych sum opadów w Polsce (rys. 8.4), jak i współczynniki trendów opadu $M C P$ i opadu całkowitego wskazują na malejący udział MCP w sumie całkowitych opadów w Polsce. Trendy sum rocznych są zbliżone, chociaż MCP stanowią zaledwie około $10 \%$ sumy 
całkowitych opadów. Malejący trend MCP jest istotny, podczas gdy całkowite opady zmniejszały się nie znacząco, a w jesieni i w zimie wykazywały słabą tendencje rosnącą (tab. 8.3).

Tab. 8.3. Wartości średnie i współczynniki kierunkowe trendów (a/50 lat) parametrów $M E C$, sum i obfitości opadów w Polsce, zawartości wilgoci w atmosferze nad Polską oraz liczby dni z makroformami cyrkulacji Vangengeima-Girsa (V-G). Wyróżniono współczynniki ( $\mathrm{p} \leq$ 0,05) (wg Degirmendžića i Kożuchowskiego, 2015b, zmienione)

\begin{tabular}{lrrrrrr}
\hline Parametry & Średnia & Rok & Wiosna & Lato & Jesień Zima \\
\hline Cyklony MEC & & & & & & \\
Liczba MEC & 6,88 & $-\mathbf{3 , 7 0}$ & $-1,32$ & $-0,43$ & $-0,80$ & $-1,13$ \\
Minimalne ciśnienie [hPa] & 997,50 & 0,15 & 0,05 & $-0,55$ & $-3,45$ & $\mathbf{6 , 3 0}$ \\
Maksymalna tendencja ciśnienia [hPa/6h] & $-2,85$ & 0,05 & 0,30 & 0,00 & $-0,75$ & 0,00 \\
Laplasjan ciśnienia [mPa/km²] & 17,40 & 0,80 & 1,70 & 2,55 & 4,45 & $-4,00$ \\
\hline
\end{tabular}

\section{Sumy opadów [mm]}

Średni opad całkowity w Polsce

$$
\begin{array}{rrrrrr}
686,8 & -28,3 & -1,8 & -29,3 & 2,6 & 3,7 \\
66,2 & \mathbf{- 2 7 , 9} & -9,0 & 1,4 & -13,0 & -\mathbf{- 7 , 8} \\
1019,5 & -57,2 & -1,7 & -57,2 & 29,1 & -12,1 \\
112,4 & \mathbf{- 6 2 , 1} & \mathbf{- 2 0 , 4} & -11,4 & \mathbf{- 1 6 , 9} & \mathbf{- 1 4 , 5} \\
605,2 & -21,7 & 1,4 & -22,8 & -3,2 & 7,3 \\
54,9 & -20,1 & -6,5 & 4,4 & -12,0 & -\mathbf{6 , 3}
\end{array}
$$

Opady MCP w Polsce

Średni opad całkowity - góry i przedgórza

Opad MCP - góry i przedgórza

Średni opad całkowity w Polsce nizinnej

Opad MCP w Polsce nizinnej

\section{Obfitość opadów [mm/dzień]}

Średnia obfitość opadów całkowitych w Polsce

$\begin{array}{llllll}4,1 & -0,29 & 0,01 & \mathbf{- 0 , 8 2} & -0,10 & -0,09\end{array}$

Obfitość opadów MCP w Polsce

$\begin{array}{llllll}5,8 & 0,78 & 0,52 & 2,35 & -1,08 & 0,22\end{array}$

Średnia obfitość opadów całkowitych

- góry i przedgórza

$\begin{array}{llllll}5,3 & -0,49 & -0,36 & -1,05 & 0,16 & -0,47\end{array}$

Średnia obfitość opadów MCP - góry i przedgórza

$\begin{array}{llllll}8,0 & -0,82 & -0,76 & 0,80 & -2,62 & -0,97\end{array}$

Średnia obfitość opadów całkowitych

w Polsce nizinnej

$\begin{array}{llllll}3,7 & -0,24 & 0,10 & -\mathbf{0 , 7 3} & -0,19 & 0,00\end{array}$

Średnia obfitość opadów MCP w Polsce nizinnej

\section{Zawartość wilgoci $w$ atmosferze [mm]}

Średnia zawartość wilgoci w atmosferze nad Polską

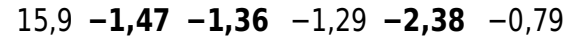

\section{Makroformy cyrkulacji V-G}

Liczba dni E

175,4-60,6 - $6-$

Liczba dni W

$\begin{array}{rrrrrr}102,4 & 75,3 & - & - & - & -\end{array}$

Liczba dni C

$\begin{array}{llllll}87,5 & -14,7 & - & - & - & -\end{array}$ 


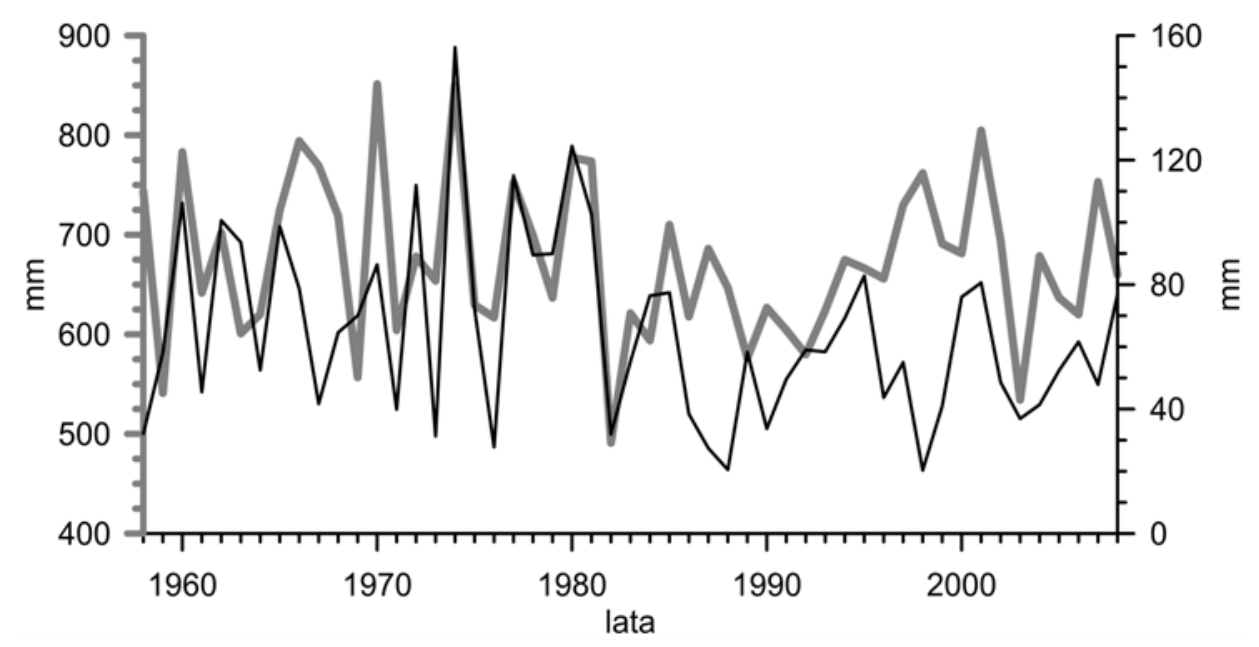

Rys. 8.4. Średnie roczne sumy opadów całkowitych w Polsce (linia pogrubiona, oś rzędnych po lewej) i opadów MCP w okresie 1958-2008 (wg Degirmendžića i Kożuchowskiego, 2015b)

Rozkład przestrzenny zmian sum opadów na obszarze Polski w latach 1961-2008 (rys. 8.2) pozwala na sformułowanie tezy, że znaczącym czynnikiem ukształtowania pola tych zmian są malejące opady pochodzenia śródziemnomorskiego. Zmniejszone opady koncentrują się na południowym zachodzie kraju i występują w południkowo zorientowanych pasmach, sięgających aż do centralnych i wschodnich dzielnic Polski.

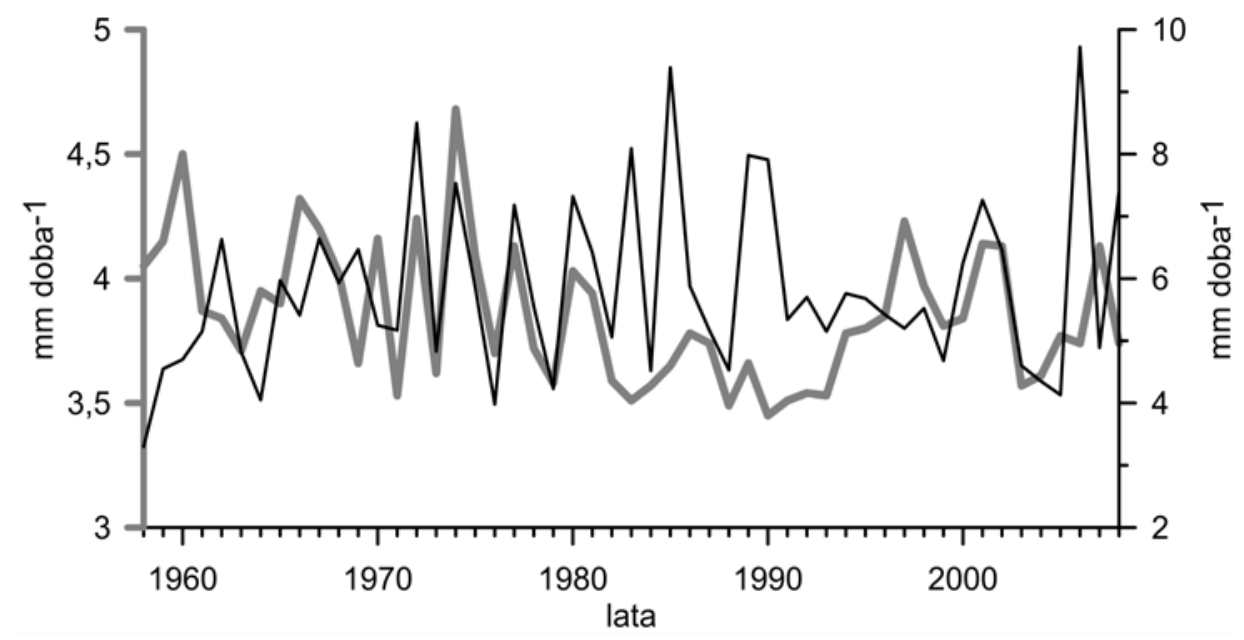

Rys. 8.5. Średnia roczna obfitość opadów całkowitych w Polsce (linia pogrubiona, oś rzędnych po lewej) i obfitość opadów MCP w okresie 1958-2008

(wg Degirmendžića i Kożuchowskiego, 2015b) 
Obfitość opadów związanych z niżami śródziemnomorskimi wykazywała wieloletnią tendencję rosnącą. Trend obfitości opadów MCP jest dodatni, a w przypadku opadów występujących w sezonie letnim w nizinnej części Polski - istotny, w przeciwieństwie do malejącego trendu obfitości całkowitych sum opadowych (tab. 8.3). Na rys. 8.5 można zauważyć rosnącą od lat 1980. przewagę obfitości opadów MCP nad obfitością całkowitych opadów w Polsce (których średnie wieloletnie wynoszą odpowiednio 5,8 i 4,1 mm/doba). Mimo malejących sum MCP ich obfitość (średni opad przypadający na dobę opadową) zwiększała się skutkiem znacznego spadku częstości niżów MEC i zarazem dni z opadami $M C P$.

\section{Zmiany zawartości wilgoci w atmosferze}

Średnia wieloletnia zawartość wilgoci w atmosferze nad Polską (PW) wynosi $15,93 \mathrm{~mm}$. Charakteryzuje ją wyraźny cykl roczny z maksimum letnim (najwyższa średnia dobowa 26,43 $\mathrm{mm}$ ) i minimum w zimie (najniższa średnia dobowa 8,53 mm). Skrajne wartości PW zawierają się w przedziale 1,86 < PW $<40,97 \mathrm{~mm}$. W przebiegu rocznym średnia zawartość wilgoci w atmosferze i obfitość opadów w Polsce są ściśle skorelowane (współczynnik korelacji wynosi 0,97$)$.

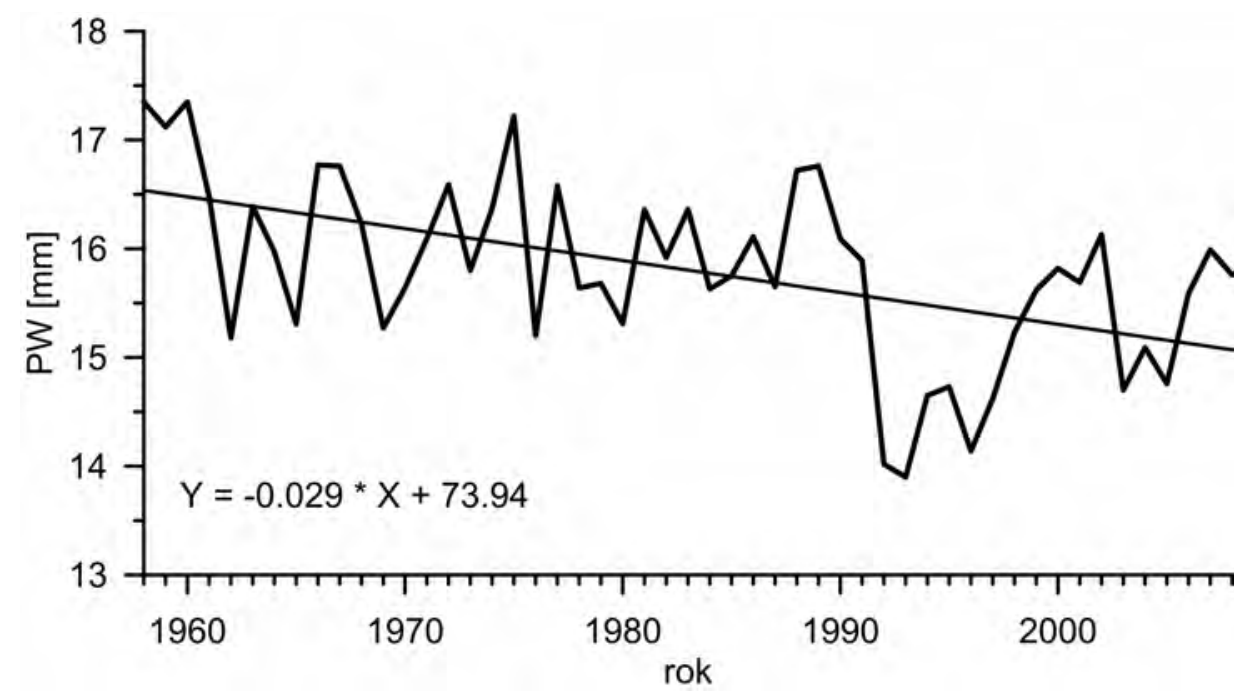

Rys. 8.6. Średnia roczna zawartość wilgoci w atmosferze nad Polską (PW) w latach 1958-2008 oraz trend liniowy PW (wg Degirmendžića i Kożuchowskiego, 2015b) 
Wieloletni przebieg zawartości wilgoci w atmosferze nad Polską charakteryzuje się tendencja malejącą (rys. 8.6). W okresie 1958-2008 średnie roczne wartości PW zmalały o prawie $10 \%$ i była to zmiana statystycznie istotna (tab. 8.3). Znacząco zmalały też średnie sezonowe PW na wiosnę i w jesieni. Szczególnie niskie średnie roczne wartości PW wystąpiły w latach 1990. (rys. 8.6). Można zauważyć zbieżność tej depresji PW z wystąpieniem znaczącego ocieplenia klimatu (szczególnie ciepły okres 1989-1995). Przede wszystkim jednak zbieżne są wieloletnie (1958-2008) trendy zawartości wilgoci w atmosferze nad Polską i liczby niżów śródziemnomorskich (rys. 8.3 i rys. 8.6). Na lata 1980. przypada zarówno „załamanie” liczebności $M E C$, jak i opadów $M C P$ oraz zawartości wilgoci w atmosferze (PW). W tym samym czasie zmalała też częstość panowania makroform cyrkulacji E, sprzyjających transportowi wilgoci z południa nad Europę Środkowo-Wschodnią, a także wędrówce niżów szlakiem Vb.

\section{Makroforma cyrkulacji południkowej E i niże śródziemnomorskie}

Makroforma E cyrkulacji odpowiada fali długiej (Rossby'ego) w położeniu, które steruje spływem powietrza w środkowej i górnej troposferze (na powierzchni izobarycznej 500-300 hPa) z północy nad zachodnimi wybrzeżami Europy i adwekcją południową nad Europą Środkowo-Wschodnią. Oś bruzdy, związanej z tą falą, biegnie od Morza Północnego na południe, sięgając Afryki na wybrzeżach Algierii (rys. 8.7). Cyrkulacja nad Europą w takiej formie ma zdecydowanie południkowy charakter, a między wschodnią (cieplejszą) i zachodnią częścią kontynentu kształtują się silne gradienty termiczne, które powodują, że atmosfera przyjmuje strukturę baroklinową, co też sprzyja cyklogenezie i wędrówce niżów dolnotroposferycznych torami zbliżonymi do szlaku $\mathrm{Vb}$.

Frekwencja niżów śródziemnomorskich w badanym okresie 1958-2008 oraz częstość występujących w tych latach makroform cyrkulacji pozwala zauważyć wyraźną zbieżność pojawiania się $M E C$ i makroform cyrkulacji południkowej E.

Niże $M E C$ pojawiają się najczęściej przy makroformie E, zwłaszcza $M E C$ wędrujące prosto na północ (szlakami C i W). Towarzyszy im ponad 1,8 razy większa od średniej częstość formy E (makroforma E występuje średnio przez $48 \%$ dni w roku, przy niżach na szlaku C i W pojawia się z częstością >70\%) 
(tab. 8.4). Niże w basenie Morza Śródziemnego oraz MEC na opadotwórczych odcinkach ich szlaków w Europie są najczęściej związane z panowaniem makroformy E (odpowiednio 67,1 i 69,4\% przypadków).

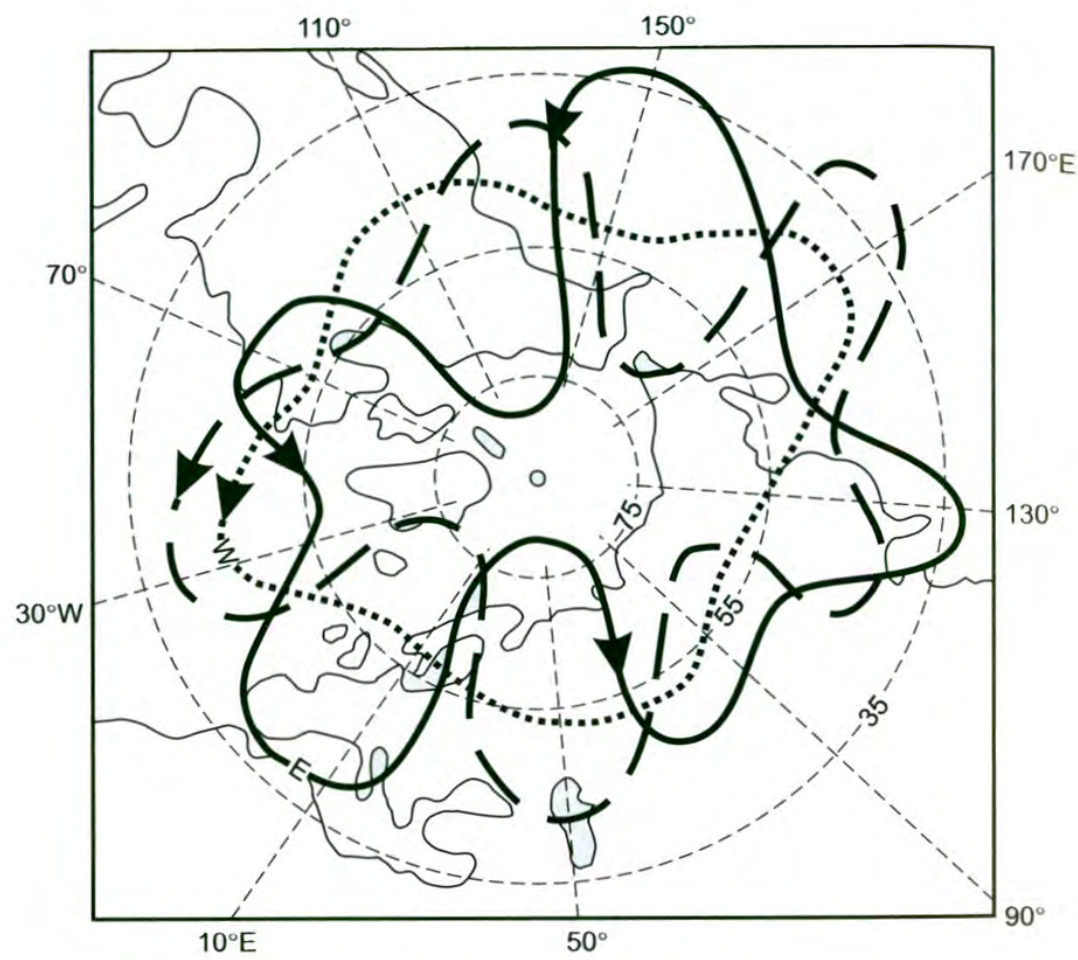

Rys. 8.7. Położenie fal długich na półkuli północnej w makroformach cyrkulacji E, C i W (wg Vangengeima-Girsa, za A. A. Marsz, 2013)

Około 1/3 przypadków MEC związanych jest z innymi formami - W lub C, przy czym łatwo jednakże zauważyć, że częstość niżów związanych z formą W lub C jest wyraźnie mniejsza od średniej częstości występowania tych form (odpowiednio 28 i 23,9\%). Niże MEC częściej i „łatwiej” powstają przy zatoce górnotroposferycznej, odpowiadającej makroformie E.

Związek niżów MEC z makroformą cyrkulacji E znajduje potwierdzenie w wieloletnim przebiegu zmian częstości $M E C$ i częstości E. Korelacja rocznej częstości $M E C$ i makroform E jest istotna, choć niezbyt wysoka - współczynnik $\mathrm{r}=0,33$. Niemniej widać, że przypadający na lata 1980. spadek frekwencji niżów MEC zbiega się z malejącą frekwencją makroform E (rys. 8.8). W ciągu półwiecza roczna liczba MEC zmniejszyła się o ponad połowę, liczba dni z makroformą E - o 35\% (por. współczynniki trendów w tab. 8.3). 
Tab. 8.4. Częstość (w \%) makroform cyrkulacji Vangengeima-Girsa (V-G) w dniach z niżami $M E C$ w okresie 1958-2008

\begin{tabular}{lcccr}
\hline \multirow{2}{*}{ Niże śródziemnomorskie MEC } & \multicolumn{3}{c}{ Makroformy V-G } & \begin{tabular}{r} 
Liczba \\
\cline { 2 - 4 }
\end{tabular} \\
\cline { 2 - 4 } & E & W & C & przypadków \\
\hline MEC w basenie Morza Śródziemnego & 67,1 & 16,2 & 16,7 & 346 \\
MEC na odcinkach opadotwórczych & 69,4 & 16,6 & 14,0 & 556 \\
MEC na odcinku szlaku E & 65,3 & 17,4 & 17,4 & 121 \\
MEC na odcinku szlaku C & 72,8 & 18,1 & 9,1 & 254 \\
MEC na odcinku szlaku W & 70,9 & 14,6 & 14,6 & 55 \\
MEC na odcinku szlaku S & 65,9 & 13,5 & 20,6 & 126 \\
Średnia roczna częstość makroform V-G & 48,0 & 28,0 & 23,9 & $51 \times 365$ \\
\hline
\end{tabular}

W okresie 1958-2008 malejącemu trendowi częstości makroformy E (-1,21 dni/rok) towarzyszyła rosnąca częstość występowania makroformy cyrkulacji W (1,51 dni/rok). Częstość tej strefowej formy cyrkulacji osiągnęła maksimum w 2008 roku (179 dni z formą W). Niewielkim trendem malejącym charakteryzowała się druga forma cyrkulacji południkowej - C $(-0,29$ dni/rok) (rys. 8.9). Można więc uznać, że w analizowanym wieloleciu, a zwłaszcza w jego drugiej połowie, rozwijała się strefowa forma cyrkulacji (W), której częstość przy końcu okresu niemal zrównała się z łączną częstością występowania dwu form cyrkulacji południkowej - E i C.

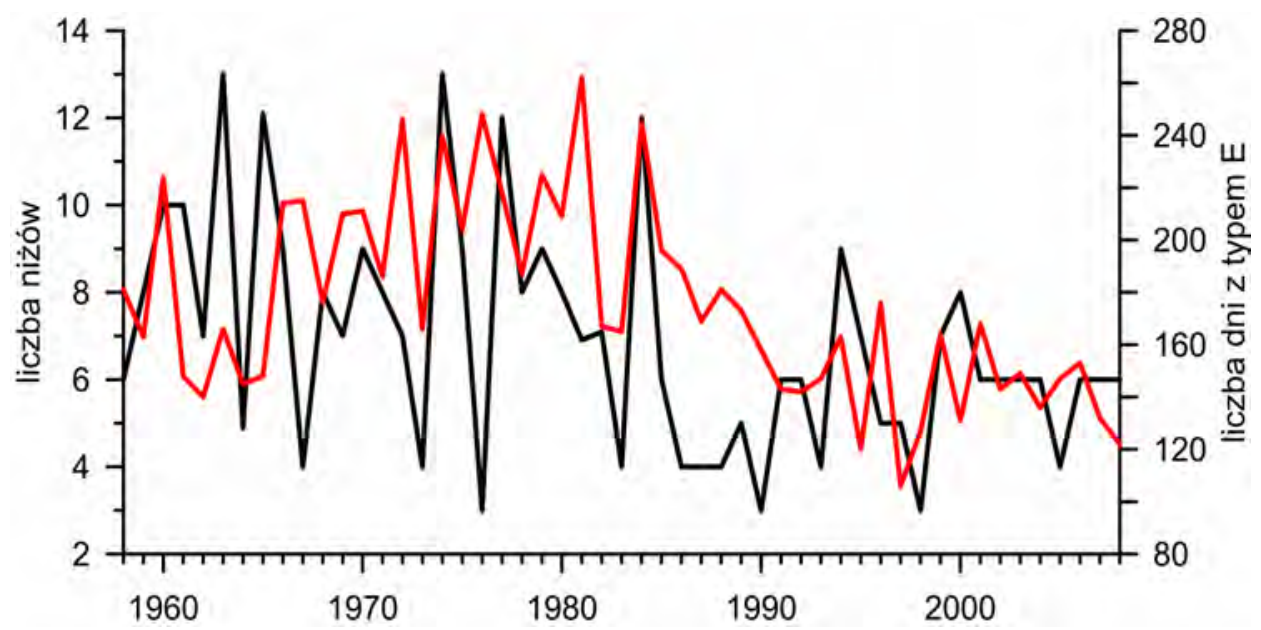

Rys. 8.8. Roczna liczba niżów śródziemnomorskich MEC (czarna krzywa) i roczna liczba dni z makrotypem cyrkulacji E (czerwona) w okresie 1958-2008 


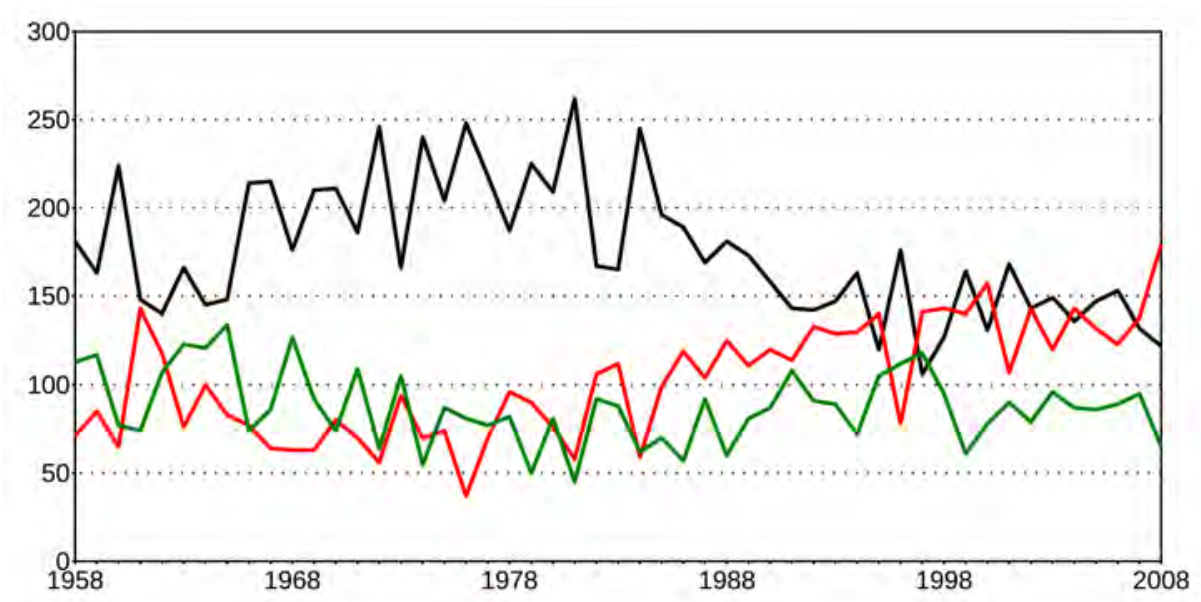

Rys. 8.9. Roczne liczby dni z makroformami cyrkulacji E (kolor czarny), W (kolor czerwony) i C (kolor zielony) w latach 1958-2008

Obserwowane tendencje wieloletnich zmian charakteru cyrkulacji atmosferycznej, przybierającej coraz częściej formę strefowego, zachodniego przepływu powietrza w środkowej i górnej troposferze stanowią wyjaśnienie stwierdzonego malejącego trendu występowania niżów wędrujących południkowymi torami nad Europą. Te same tendencje mogą też sugerować, że pod koniec XX wieku ukształtowała się kolejna epoka cyrkulacyjna, w której dominującą rolę spełniają strefowe formy cyrkulacji. Taką epokę zapowiadali już wcześniej Sidorenkov i Svirenko (1983), którzy okres 1973-2005 określili mianem epoki W+E, bądź Surova (1984), która koniec XX wieku zaliczyła do epoki $\mathrm{W}+\mathrm{C}$. Być może warunki cyrkulacyjne powracają do stanu, który je cechował na przełomie XIX i XX wieku i któremu odpowiadały epoki cyrkulacyjne W+C (1891-1899) i W (1900-1928) (wg Girsa, 1971).

Makroformy W i C nie sprzyjają wędrówce niżów śródziemnomorskich na północ. Niże $M E C$, jak już wyżej zauważono, związane są przede wszystkim z aktywnością makroformy E.

O korelacji występowania $M E C$ z makroformą cyrkulacji E świadczy średnie ukształtowanie pola geopotencjału powierzchni $500 \mathrm{hPa}$, towarzyszące niżom na ich opadotwórczych odcinkach szlaków E, C, W i S (rys. 8.10). Izohipsy powierzchni $500 \mathrm{hPa}$ odzwierciedlają położenie zatoki rozciągającej się znad północnej Europy na południe - jej wschodnie skrzydło wyznacza szlaki niżów MEC: szlakowi wschodniemu (E), a także południowemu (S) odpowiadają zatoki przesunięte ku wschodowi, natomiast szlakowi centralnemu (C) i zachodniemu (W) towarzyszą zatoki o osiach leżących na zachód od pozosta- 
łych. Przebieg izohips nawiązuje do ukształtowania pola geopotencjału powierzchni $500 \mathrm{hPa}$, reprezentowanego przez makroformę cyrkulacji E; wskutek uśrednienia ich południkowy układ jest nieco „rozmyty”, ale podstawowe elementy pola geopotencjału pozostają wspólne z makroformą - nad zachodnią Europą odzwierciedlają one istnienie północnej składowej adwekcji w środkowej troposferze, nad wschodnią częścią Europy widoczna jest składowa południowa.

Makroformy E, C i W stanową pewien modelowy schemat cyrkulacji, któremu w mniejszym lub większym stopniu odpowiadają realne układy cyrkulacyjne. Uśrednione pole geopotencjału, związane z niżami $M E C$ na szlakach ich wędrówki (rys. 8.10) uwzględnia także ewolucję tego pola (wraz z możliwą zmianą makroformy) w ciągu całego czasu aktywności niżów.

W celu dalszej weryfikacji tezy, zakładającej korelację występowania niżów MEC z makroformą cyrkulacji południkowej E rozpatrzono kilka przypadków ukształtowania izopowierzchni $500 \mathrm{hPa}$ w dniach występowania aktywnych $M E C$ i związanych z nimi wysokich opadów MCP w Polsce. Wybrano cztery doby, charakteryzujące się ekstremalnymi opadami w różnych miejscowościach Polski (tab. 8.5). Przedstawiono mapy geopotencjału powierzchni $500 \mathrm{hPa}$ z tych 4 . terminów (rys. 8.11-8.14).

Ukształtowanie powierzchni $500 \mathrm{hPa}$ nad Europą z dnia 21.08.1972 r. (rys. 8.11) charakteryzowało się układem najwyraźniej zbieżnym z modelem makrotypu cyrkulacji E. Od Skandynawii aż do Adriatyku i południowej części Półwyspu Apenińskiego rozciągała się głęboka bruzda z depresją, zlokalizowaną nad Węgrami i świadczącą o znacznej amplitudzie i rozwijającym się „odcięciu” fali długiej w jej położeniu nad Europą Środkową. Na wschodzie Europy zalegał wierzchołek tej fali, sięgający aż poza północne wybrzeża Rosji i powodujący blokadę cyrkulacji strefowej nad większą częścią Europy.

Tab. 8.5. Opady MCP i towarzyszące im makroformy cyrkulacji V-G

\begin{tabular}{lclccc}
\hline $\begin{array}{l}\text { Data } \\
\text { (dzień } \mathbf{n})\end{array}$ & $\begin{array}{c}\text { Opad dobowy } \begin{array}{c}\text { MCP } \\
\text { [mm] }\end{array} \\
\text { Stacja }\end{array}$ & \multicolumn{3}{c}{ Makroforma V-G } \\
\cline { 3 - 5 } 21.08 .1972 & 147 & Bielsko-Biała & w dniu n & w dniu n-1 & w dniu n-2 \\
30.07 .1977 & 150 & Śnieżka & E & E & E \\
08.08 .1978 & 133 & Słubice & W & W & W* \\
08.07 .1997 & 224 & Hala Gąsienicowa & C & E & E \\
\hline
\end{tabular}

* - makroforma E wystapiła $w$ dniu n-6 

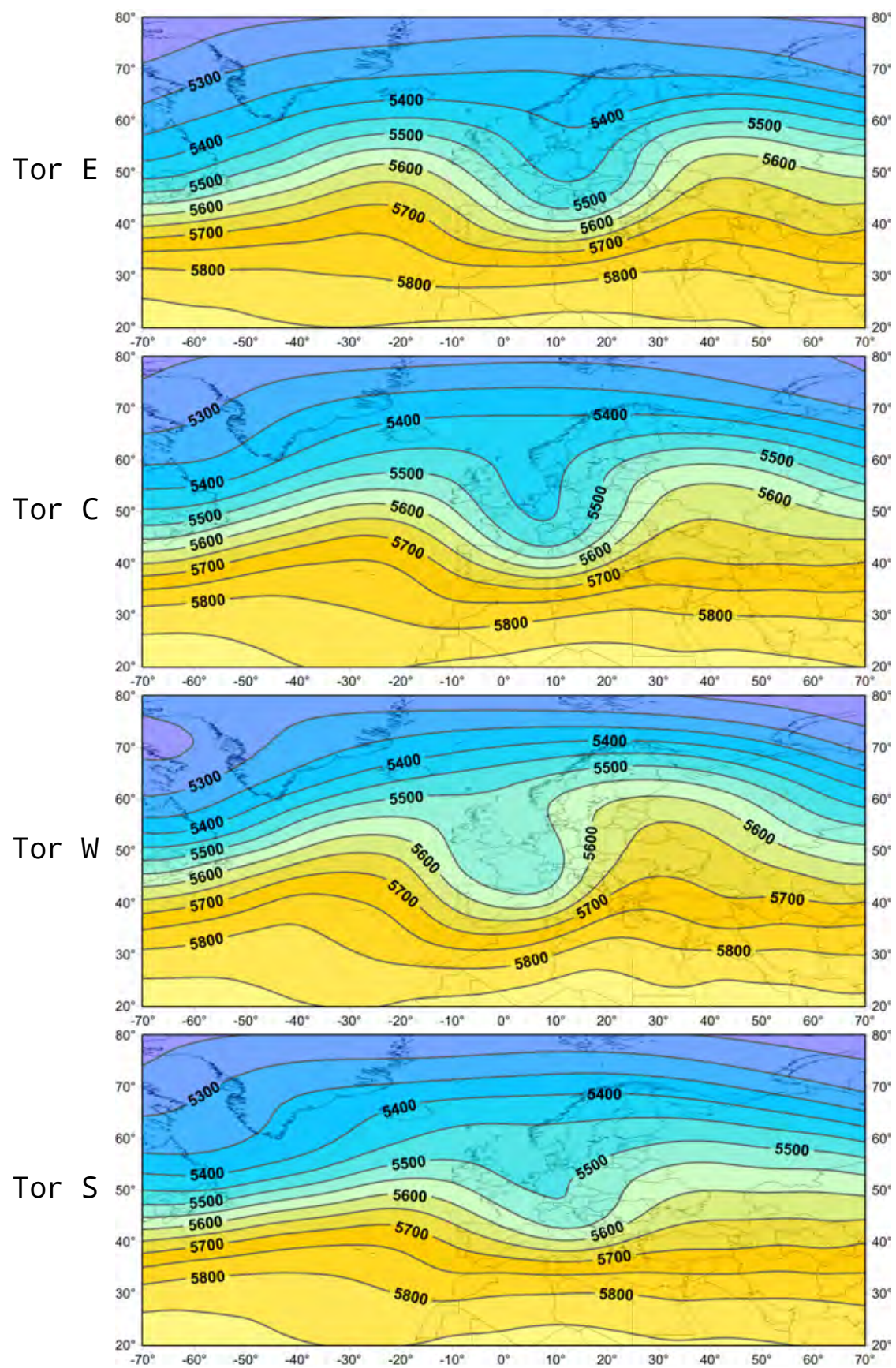

Rys. 8.10. Średnie pole geopotencjału powierzchni $500 \mathrm{hPa}[\mathrm{m}] \mathrm{w}$ terminach, w których niże $M E C$ znajdowały się na opadotwórczych odcinkach torów E, C, W, S. Okres 1958-2008 
W przypadku z dnia 30.07.1977 r. makrotyp cyrkulacji E wystąpił w „zaburzonej" postaci. Właściwa mu dolina fali długiej uległa rozczłonkowaniu, w jej zachodniej części - nad Francją ukształtowała się najgłębsza depresja w polu izopowierzchni $500 \mathrm{hPa}$, drugi człon depresji rozciągał się jednak od Skandynawii po Ukrainę, a makroformie E (wg kalendarza Dimitreeva i Belyazo, 2006) odpowiadały jedynie izohipsy, rozciągające się południkowo na odcinku od Irlandii do Portugalii oraz od Morza Białego po Morze Kaspijskie (rys. 8.12). Rozpatrywany przypadek reprezentuje długotrwały epizod panowania i ewolucji makroformy cyrkulacji E (26.07-12.08.1977 r.), a widoczne na mapie izopowierzchni $500 \mathrm{hPa}$ zaburzenie fali długiej (klin nad południową Europą) stanowi zapowiedź przekształcenia makroformy E w makroformę C, która pojawiła się jednak dopiero po dwu tygodniach (13.08.1977 r.).

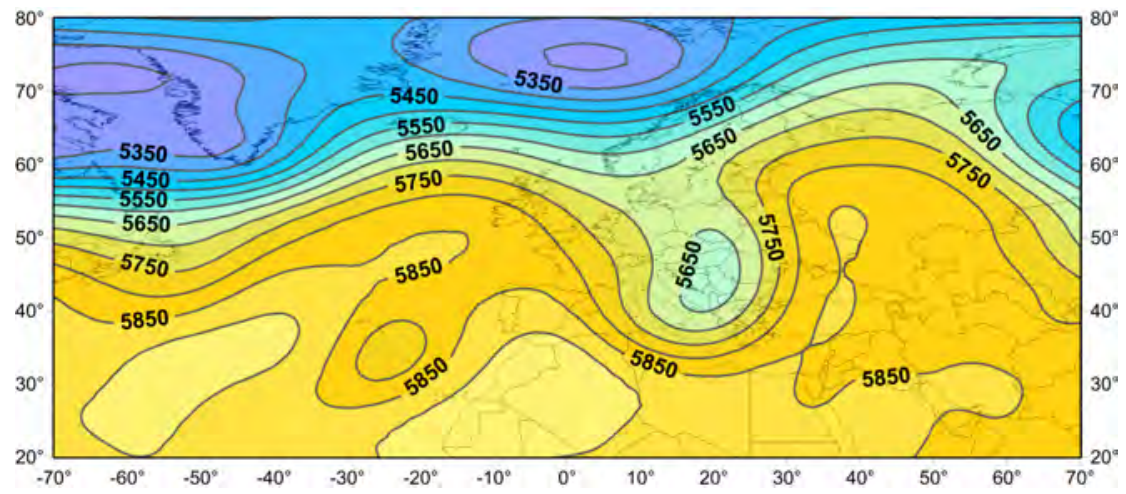

Rys. 8.11. Pole geopotencjału powierzchni 500 hPa [m] w dniu 21.08.1972 r.

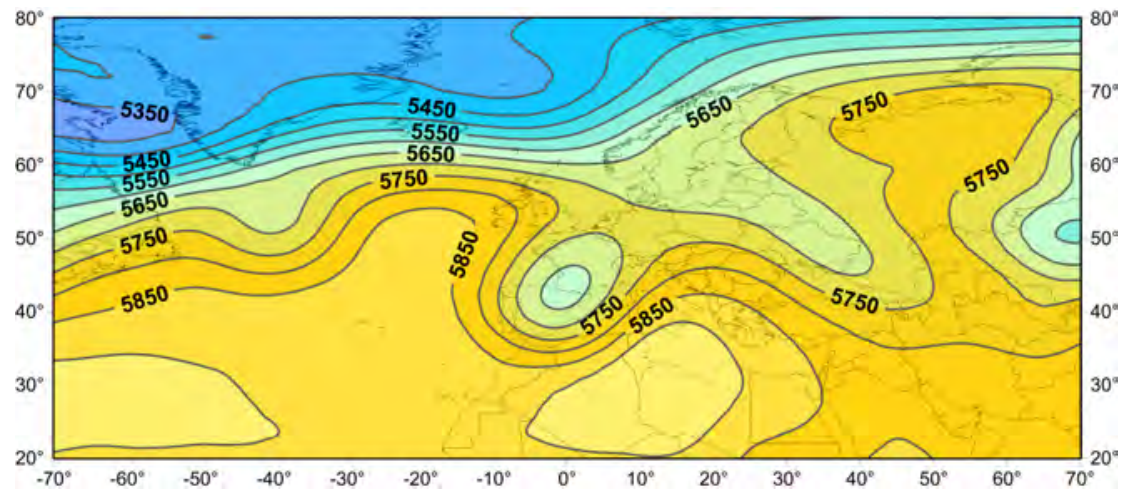

Rys. 8.12. Pole geopotencjału powierzchni 500 hPa [m] w dniu 30.07.1977 r. 
W przypadku z dnia 08.08.1978 r. (rys. 8.13) oś zatoki w polu izopowierzchni 500 hPa biegła od Finlandii do Morza Północnego, ale nad przeważająca częścią Europy izohipsy miały przebieg strefowy, stąd więc w kalendarzu makroform cyrkulacji cały układ cyrkulacyjny zakwalifikowano jako makroformę W, która jednak już w kolejnym dniu (9.08.1978 r.) przekształciła się w południkowy makrotyp cyrkulacji C. Niemniej, zatoka w polu izopowierzchni $500 \mathrm{hPa}$ nad północna i zachodnią Europą była w analizowanym przypadku obecna, a jej położenie sprawiło, ze właśnie w Słubicach odnotowano ekstremalnie wysoki opad MCP (tab. 8.5).

Skutkiem odcięcia doliny fali długiej, reprezentującej makrotyp E, ukształtowała się sytuacja w dniu 08.07.1997 r. (rys. 8.14). Ślad makroformy E reprezentuje wyraźna depresja, ulokowana przy południowo-wschodnich granicach Polski, z centrum nad Wschodnimi Karpatami. Izohipsy nad środkowo-wschodnią Europą występowały w układzie zbliżonym do opisanego wyżej układu z dnia 21.08.1972 r. (rys. 8.11). Za charakterystyczną cechę wszystkich wybranych tu przypadków układów cyrkulacyjnych, generujących wysokie opady $M E C$ w Polsce, można więc uznać wyróżniające się, oderwane depresje w polu $500 \mathrm{hPa}$, kształtujące cyklonalne zawirowanie w troposferze.

Przypadek z dnia 08.07.1997 r. reprezentuje warunki cyrkulacyjne, które przyczyniły się do powstania pierwszej fali nawalnych opadów, trwających od 4. do 9.07.1997 r. i wywołujących „powódź tysiąclecia” w lipcu 1997 r. Opady dobowe 8.07.1997 r. w Beskidzie Śląskim, Małym, Żywieckim, w Gorcach i na Podhalu z reguły były wyższe od $100 \mathrm{~mm}$ (w Poroninie opad dobowy osiągnął $156 \mathrm{~mm}$ ). W Tatrach opady przekroczyły $200 \mathrm{~mm}$ (Hala Gąsienicowa 224, Dolina Pięciu Stawów $208 \mathrm{~mm}$ ). W ciągu całego 6-dniowego okresu tych deszczów stacje w Sudetach oraz w zachodniej części Polskich Karpat notowały opady sięgające ponad $400 \mathrm{~mm}$ (Grela i in., 1997).

Kierunki adwekcji mas powietrza napływających nad rejon Raciborza na poziomach 500, 2000 i 4000 m n.p.t. podczas epizodu nawalnych opadów 5 i 7 lipca 1997 r. opisała Świątek (2013a). Początkowo, (5.07) do południowej Polski docierało wilgotne i ciepłe powietrze znad Morza Śródziemnego, następnie jednak (7.07) kierunek adwekcji zmienił się zasadniczo, a trajektorie ruchu mas powietrza na poziomie 500 i $2000 \mathrm{~m}$ n.p.t. wskazywały na adwekcję z północy i północnego-wschodu, wyżej (4000 m n.p.t.) - utrzymywała się nadal adwekcja „powietrza śródziemnomorskiego”.

Rekonstrukcja trajektorii wstecznych ruchu powietrza w dniach 4, 6 . i 8.07.1997 r. potwierdza znamienną ewolucję cyrkulacji podczas występowania nawalnych deszczów w lipcu 1997 r. (rys. 8.15-8.17). 


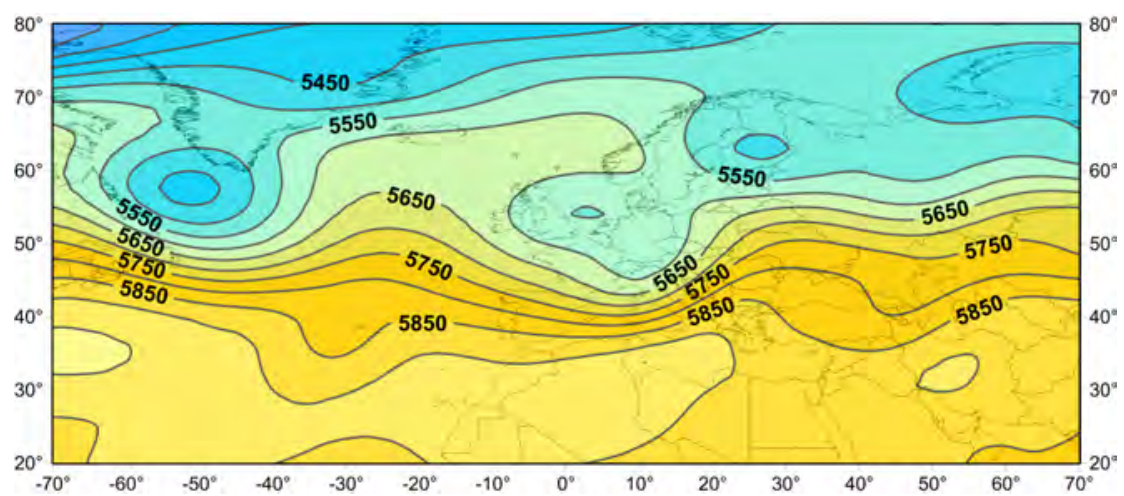

Rys. 8.13. Pole geopotencjału powierzchni 500 hPa [m] w dniu 08.08.1978 r.

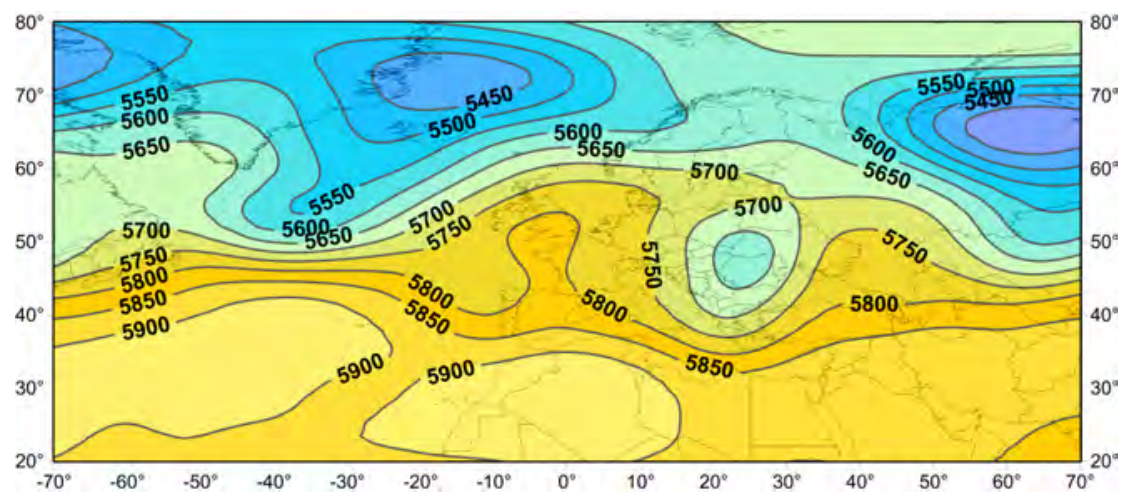

Rys. 8.14. Pole geopotencjału powierzchni $500 \mathrm{hPa}[\mathrm{m}] \mathrm{w}$ dniu 8.07.1997 r.

Dnia 4 lipca nad południową Polskę napływało powietrze znad Morza Śródziemnego, ale w środkowej i północnej części kraju zidentyfikowano masy pochodzenia atlantyckiego, m.in. znad Zatoki Biskajskiej (rys. 8.15). Istotna wydaje się zbieżność tych dwu „strumieni” nad Dolnym Śląskiem i Wyżynami. Dnia 6 lipca adwekcja nad Polską przybrała północny kierunek, choć jednak źródłowy obszar napływających mas powietrza znajdował się na zachodzie Europy (rys. 8.16). Północna składowa ruchu ujawniła się najwyraźniej w dniu 8 lipca, równocześnie z najwyższymi opadami w górach (rys. 8.17). Niewątpliwie efekt orograficzny, ale także i widoczna zbieżność trajektorii napływających z północnego zachodu i z północnego wschodu mas powietrza stały się głównymi przyczynami tak wysokich opadów w tym dniu. 


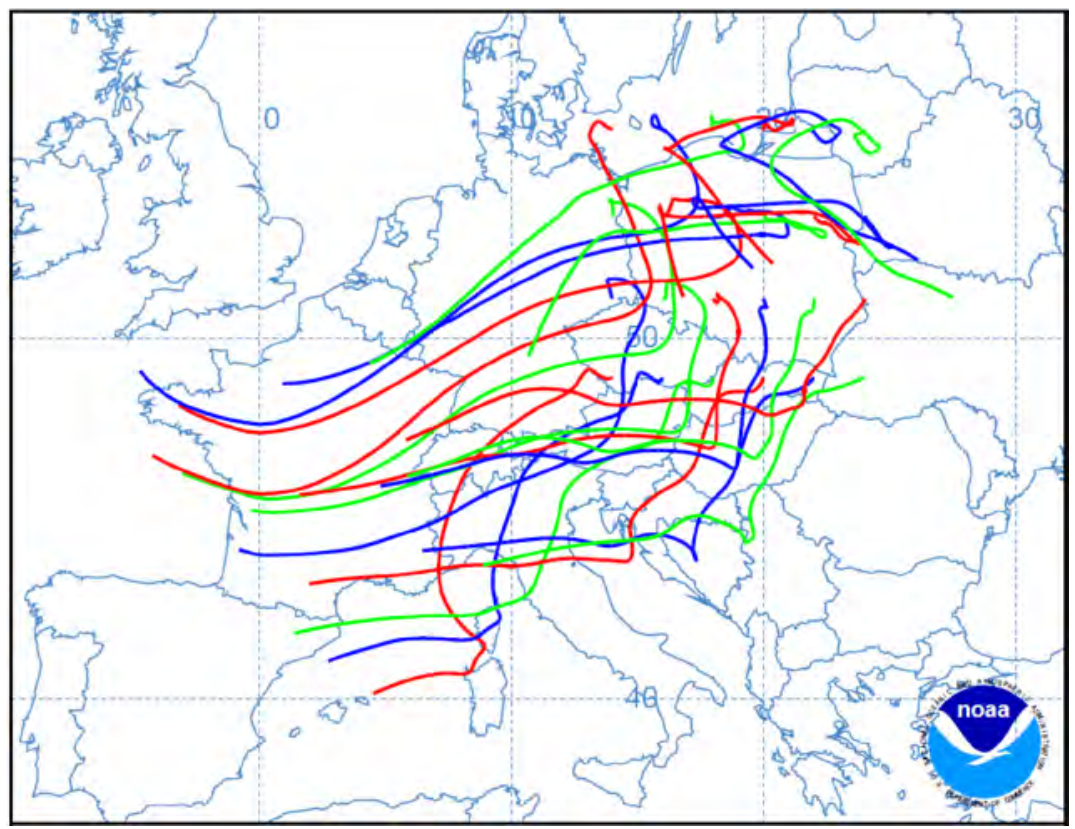

Rys. 8.15. Trajektorie wsteczne 96 godzinne z godz. 12 UTC dnia 4.07.1997 r. Punkty docelowe trajektorii w obszarze między 14 i $24^{\circ} \mathrm{E}$ i między 49 i $55^{\circ} \mathrm{N}$, rozmieszczone co $2^{\circ}$ szerokości i długości geograficznej na wys. $500 \mathrm{~m}$ n.p.t.

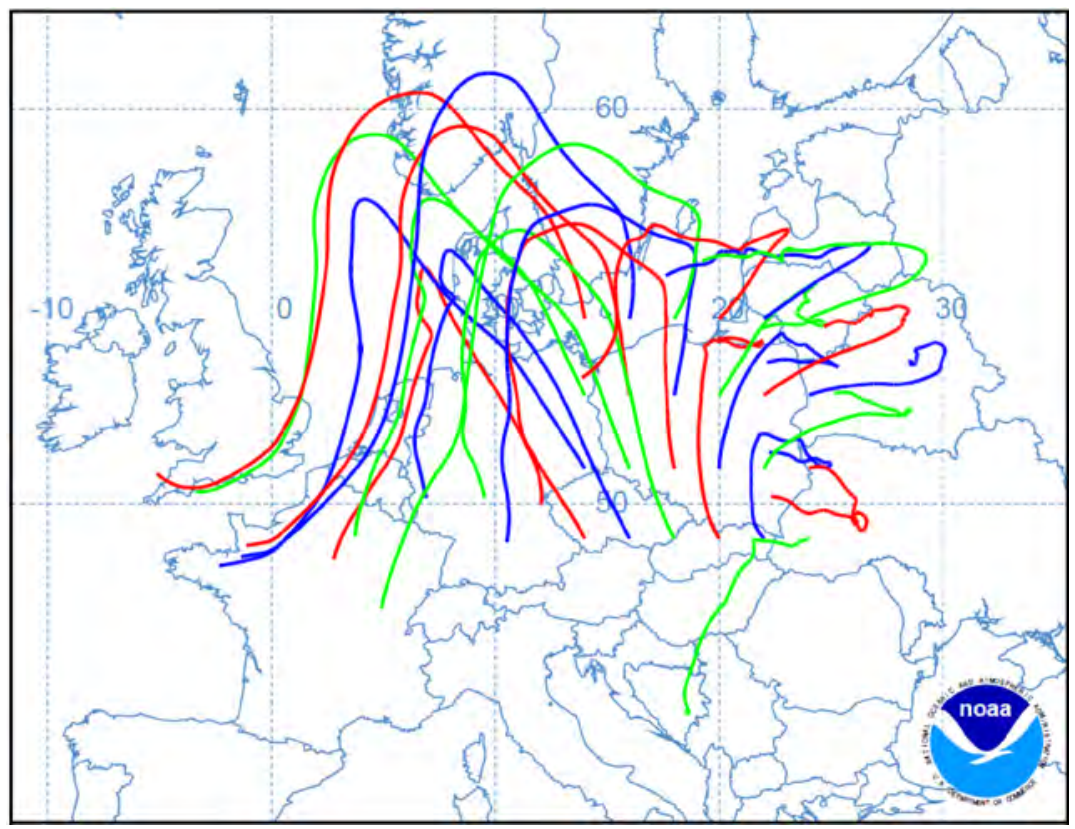

Rys. 8.16. Jak na rys. 8.15 - trajektorie z dnia 6.07.1997 r. 


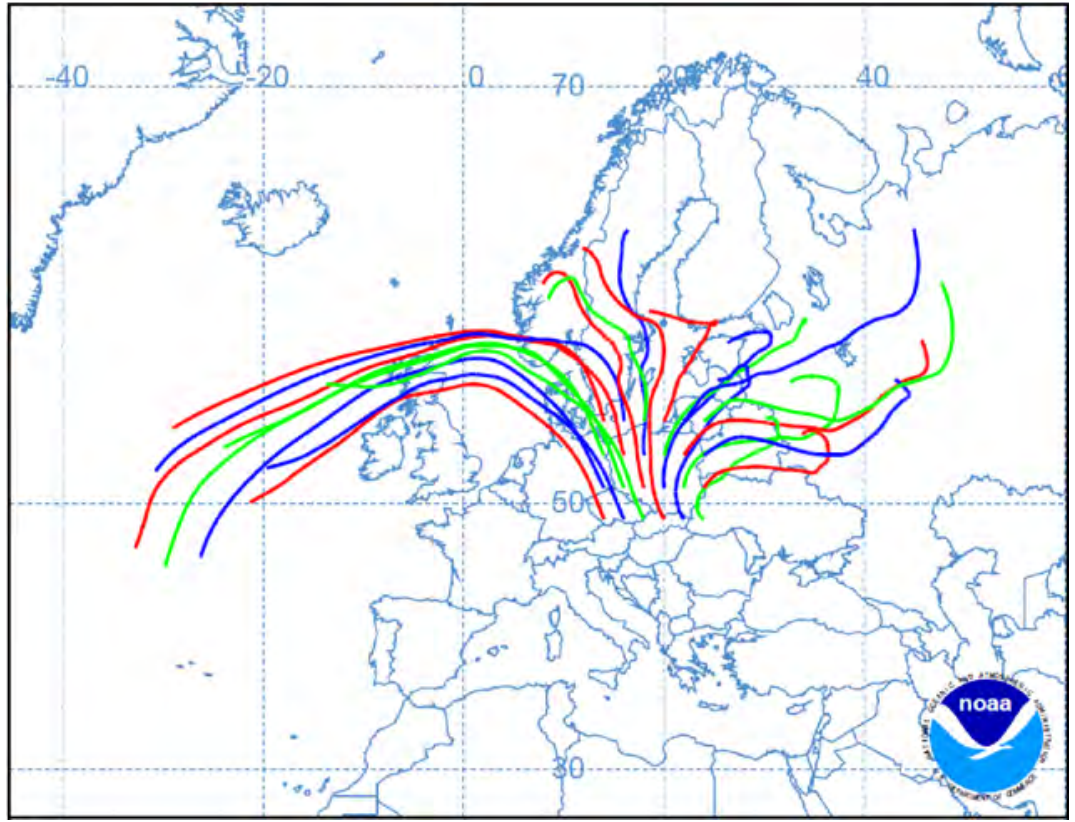

Rys. 8.17. Jak na rys. 8.15 - trajektorie z dnia 8.07.1997 r.

\section{Wnioski}

W wieloleciu 1958-2008 zmalała całkowita liczba zidentyfikowanych niżów śródziemnomorskich, docierających do Europy ŚrodkowoWschodniej. Roczna liczba MEC wykazuje istotny trend zniżkowy $(-3,7 / 50$ lat przy średniej 6,9). Największy ubytek częstości dotyczy niżów wędrujących torem wschodnim oraz niżów w sezonie wiosennym i jesiennym.

W analizowanym okresie 1958-2008 roczne sumy MCP w Polsce zmniejszyły się o $29 \mathrm{~mm}$, co stanowi $43 \%$ ich średniej wieloletniej wysokości. Trendy opadowe wskazują na malejący udział MCP w sumie całkowitych opadów w Polsce. Obfitość opadów MCP nie zmieniła się jednak znacząco.

Wieloletni przebieg zawartości wilgoci w atmosferze nad Polską charakteryzuje się również tendencja malejącą. W okresie 1958-2008 średnie roczne wartości PW zmalały o prawie $10 \%$ i była to zmiana statystycznie istotna. 
Niże w basenie Morza Śródziemnego oraz MEC na opadotwórczych odcinkach ich szlaków w Europie są najczęściej związane z panowaniem makroformy cyrkulacji południkowej E (odpowiednio 67,1 i 69,4\% przypadków).

Średni układ izohips powierzchni $500 \mathrm{hPa}$, odpowiadający występowaniu niżów $M E C$, nawiązuje do ukształtowania pola geopotencjału powierzchni $500 \mathrm{hPa}$, reprezentowanego przez makroformę cyrkulacji E. Najistotniejszą cechą tego pola, towarzyszącą formowaniu się i wędrówce $M E C$ jest południkowo zorientowana zatoka (wraz z odseparowaną w niej depresją) w środkowej troposferze nad Europą Środkową oraz zróżnicowane i zmienne kierunki adwekcji w dolnej troposferze.

Związek niżów MEC z makroformą cyrkulacji E znajduje potwierdzenie w wieloletnim przebiegu zmian częstości MEC i częstości E. Korelacja rocznej częstości niżów MEC i makroform E jest istotna, choć niezbyt wysoka - współczynnik $r=0,33$. Przypadający na lata 1980. spadek frekwencji $M E C$ zbiega się z malejącą frekwencją makroform E. W ciągu półwiecza roczna liczba niżów $M E C$ zmniejszyła się o ponad połowę, liczba dni z makroformą E - o 35\%. Malejąca zawartość wilgoci w atmosferze nad Polską ma też prawdopodobnie związek z tymi tendencjami.

Jeśli niże $M E C$, a zwłaszcza związane z nimi wysokie opady atmosferyczne zaliczyć można do kategorii zjawisk ekstremalnych, to hipoteza o rosnącej częstości tych zjawisk w epoce współczesnego ocieplenia klimatu, w świetle przeprowadzonych analiz, nie znajduje potwierdzenia.

Degirmendžić J., Kożuchowski K., 2015a, Precipitation of the Mediterranean origin in Poland - its seasonal and long-term variability. Quaestiones Geographicae, vol. 34, z.1, s.37-53;

Degirmendžić J., Kożuchowski K., 2015b, The Mediterranean cyclones, precipitable water and precipitation in Poland. Geographia Polonica (w druku) 


\section{Rozdział 9 \\ Niże śródziemnomorskie a warunki cyrkulacyjne w górnej troposferze}

W celu scharakteryzowania procesów górnotroposferycznych mających wpływ na rozwijające się niże $M E C$ sporządzono średnie pola wiatru, dywergencji całkowitej oraz dywergencji związanej z jet streak ${ }^{9}$ (ageostrophic transverse divergence, zob. opis $\mathrm{w}$ rozdz. 3) na powierzchni izobarycznej $300 \mathrm{hPa}$. Pola te uśredniono w terminach występowania MEC na opadotwórczych odcinkach trajektorii.

Z niżami śródziemnomorskimi, które przemieszczają się nad Europę Środkowo-Wschodnią związana jest górna zatoka o osi usytuowanej nad zachodnią Europą (rys. 9.1). Oś przesuwa się na zachód (znad Niemiec nad Francję) wraz ze zmianą toru niżów MEC z E i C do W. W trakcie takiej zmiany pozycji fala także ulega skróceniu - trajektorii W towarzyszy odcięty układ niskiego ciśnienia widoczny $\mathrm{w}$ uśrednionym polu wiatru. Wędrówka niżu wzdłuż trajektorii E, C, W lub S związana jest z obecnością jet streak rozwiniętym w podzwrotnikowym prądzie strumieniowym (STJ - Subtropical Jet). Jet streak usytuowane są w dolinie zatoki; nieco na wschód od jej osi w przypadku torów E i C. Posiadają one krzywiznę cyklonalną, co powoduje wzmocnienie stref dywergencji po tej stronie prądu strumieniowego (Beebe i Bates, 1955). Wyjątkiem jest jet streak związany z torem południowym niżów (S), który wykazuje charakter quasi-prostoliniowy. Jet streak występują nad zachodnią częścią akwenu Morza Śródziemnego oraz nad północną Afryką. Średnia maksymalna prędkość wiatru w obrębie każdego z jet streak przekracza nieznacznie $30 \mathrm{~ms}^{-1}$ (rys. 9.1). Warto odnotować, że jedynie z trajektorią

${ }^{9}$ Autorzy wykorzystują w tekście pojęcie jet streak - jest to $\alpha$-mezoskalowe maksimum prędkości wiatru osadzone w osi prądu strumieniowego. Z uwagi na brak syntetycznego polskiego odpowiednika tego pojęcia, w tekście występuje słowo jet streak zaznaczone kursywą. 
E (zbliżoną do toru $\mathrm{Vb}$ ) związany jest słaby jet streak widoczny również w prądzie polarnym $\left(\sim 21 \mathrm{~ms}^{-1}\right)$ nad Litwą, Łotwą i Estonią. Obecność dwóch jet streak (drugi o krzywiźnie antycyklonalnej położony w dół strumienia względem jet streak osadzonego w osi STJ) może wzmacniać dywergencję pomiędzy nimi (Uccellini i Kocin, 1987).

Warto zaznaczyć, że niektóre scenariusze zmian klimatu prognozują przesunięcie atlantyckiego prądu strumieniowego dalej na wschód, nad Europę (Pinto i in., 2009). Taki proces mógłby spowodować przemieszczenie zatoki widocznej na rys. 9.1 także na wschód i w konsekwencji spadek liczby MEC wędrujących nad Europę Środkowo-Wschodnią.

Najsilniejsza dodatnia dywergencja $\left(10 \times 10^{-6} \mathrm{~s}^{-1}\right)$ związana jest $\mathrm{z}$ dwoma sprzężonymi jet streak rozwiniętymi w okresie wędrówki niżów wschodnich (E) nad Europę Środkowo-Wschodnią (rys. 9.2). Pole wiatru w górnej troposferze uśrednione w terminach występowania niżów C oraz S generuje dywergencję nieco słabszą - $\mathrm{w}$ rejonie nad średnim cyklonem rozwija się dywergencja ok. $8 \times 10^{-6} \mathrm{~s}^{-1}$. Niże na torze $\mathrm{W}$ związane są $\mathrm{z}$ jeszcze słabszym wsparciem z górnej troposfery (ok. $7 \times 10^{-6} \mathrm{~s}^{-1}$ ). Warto zwrócić uwagę, że w okresach dominacji niżów $M E C$ nad Europą rozwinięty jest dipol dywergencji - obszary dodatniej dywergencji pokrywają środkową (aż do granicy niemiecko-francuskiej) i wschodnią Europę, konwergencja rozwija się nad zachodnią Europą. Dipol związany z torem W przesunięty jest nieco dalej na zachód (rys. 9.2). Dipol dywergencji sugeruje silny związek pola tego parametru z krzywizną fali - we wschodnim skrzydle rozwija się dodatnia dywergencja, w zachodnim konwergencja. Maksima górnej dywergencji widoczne nad obszarami aktywności MEC wskazują na największy udział górnej troposfery w kształtowaniu aktywności niżów E, a najsłabszy w przypadku niżów klasy W.

Średnia dywergencja nad niżami $M E C$, z zakresu $7-10 \times 10^{-6} \mathrm{~s}^{-1}$, jest zbliżona do wartości charakterystycznych dla bomb (cyklonów o standaryzowanej tendencji ciśnienia < -1 Bergeron) występujących nad Europą i północnym Atlantykiem (Degirmendžić, 2011). Klasę modalną bomb stanowi przedział 8-10 × $10^{-6} \mathrm{~s}^{-1} \mathrm{w}$ każdej porze roku z wyjątkiem lata. To porównanie sugeruje, że niże $M E C$ na opadotwórczych odcinkach ich trajektorii mogą cechować się znaczną aktywnością. Taki wniosek potwierdzają także badania wpływu górnej dywergencji na dynamikę niżów - układy niskiego ciśnienia pogłębiają się, a także zwiększają swoją wirowość (dodatni przyrost laplasjanu ciśnienia), kiedy średnia dywergencja w górnej troposferze w ich sąsiedztwie przekracza ok. $5 \times 10^{-6} \mathrm{~s}^{-1}$ (Sauer, 1995 - rys. 76; Degirmendžić, 2011). 
Pole dywergencji związanej z jet streak (obliczonej na podstawie pola składowej ageostroficznej normalnej względem przepływu geostroficznego, zob. rozdz. 3) cechuje się najwyższymi wartościami - ok. 3,5 × 10-6 $\mathrm{s}^{-1}$ - w przypadku niżów klasy E (rys. 9.3). Region górnej troposfery o podwyższonych wartościach dywergencji rozciąga się wzdłuż szlaku E. Podwyższona dywergencja wiąże się z dwoma sprzężonymi układami jet streak, pierwszym usytuowanym w górę strumienia w STJ oraz drugim osadzonym w osi PFJ (Polar Front Jet - polarny prąd strumieniowy). Taka konfiguracja powoduje nałożenie pola dodatniej dywergencji związanej z deltą jet streak STJ oraz dywergencji związanej z sektorem wejścia jet streak PFJ (tzw. Delta-entrance dual jet configuration). Podobne sprzężenie dwóch układów jet streak towarzyszyło cyklonowi Kyrill II rozwijającemu się nad Europą (Fink i in., 2009).

Warto zauważyć, że pole dywergencji związanej z jet streak w okresach dominacji niżów E pokrywa się z rozkładem przestrzennym gęstości trajektorii niżów Vb, prezentowanym przez Nissen i in. (2013 - rys. 9). Fakt ten wskazuje, że jet streak osadzone w podzwrotnikowym prądzie strumieniowym są ważnym czynnikiem w aktywizacji niżów MEC.

Maksimum dywergencji towarzyszące niżom klasy $C$ jest niższe (ok. $2 \times 10^{-6} \mathrm{~s}^{-1}$ ) prawdopodobnie wskutek braku rozwiniętego jet streak w polarnym prądzie strumieniowym. Najsłabsza dywergencja związana z jet streak towarzyszy niżom poruszającym się szlakiem W. Warto zauważyć kwadrupol w polu dywergencji związanej z południową trajektorią MEC. Rozkład ten pozostaje w zgodzie z modelem 4QM (Four Quadrant Model - model 4-sektorowego jet streak) quasi-prostoliniowego jet streak, według którego dodatnie wartości sytuują się w prawym sektorze wejścia (RR) i lewym sektorze wyjścia (LF), konwergencja natomiast widoczna jest w lewym sektorze wejścia (LR) oraz prawym sektorze wyjścia (RF) (m.in. Beebe i Bates, 1955). Wymienione strefy można zaobserwować nad północną Afryką w rejonie gór Atlas (RR, maks. +0,5 × $10^{-6} \mathrm{~s}^{-1}$ ), nad Słowacją, Polską, Węgrami i Ukrainą (LF; maks. $2 \times 10^{-6} \mathrm{~s}^{-1}$ ), nad Francją w rejonie Pirenejów (LR; min. $-1 \times 10^{-6} \mathrm{~s}^{-1}$ ) oraz nad Morzem Jońskim (RF; min. $-0,5 \times 10^{-6} \mathrm{~s}^{-1}$ ) (rys. 9.3). 

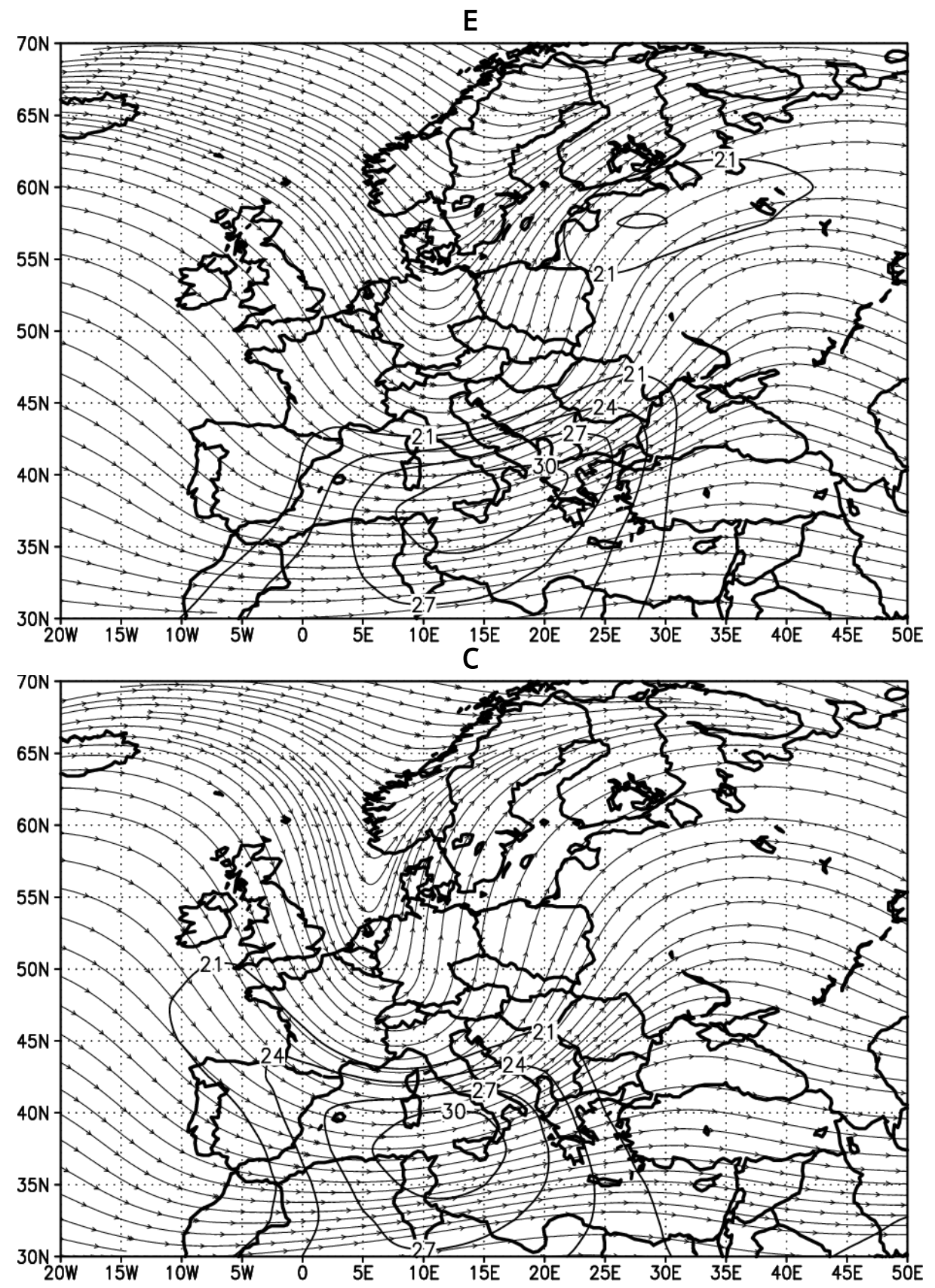

Rys. 9.1. Pola wiatru na powierzchni $300 \mathrm{hPa}$ (linie prądu, izotachy $>20 \mathrm{~ms}^{-1}$ ) uśrednione w terminach występowania niżów $M E C$ na opadotwórczych odcinkach trajektorii E, C, S oraz W. Okres 1958-2008 (wg Degirmendžića i Kożuchowskiego, 2016) 

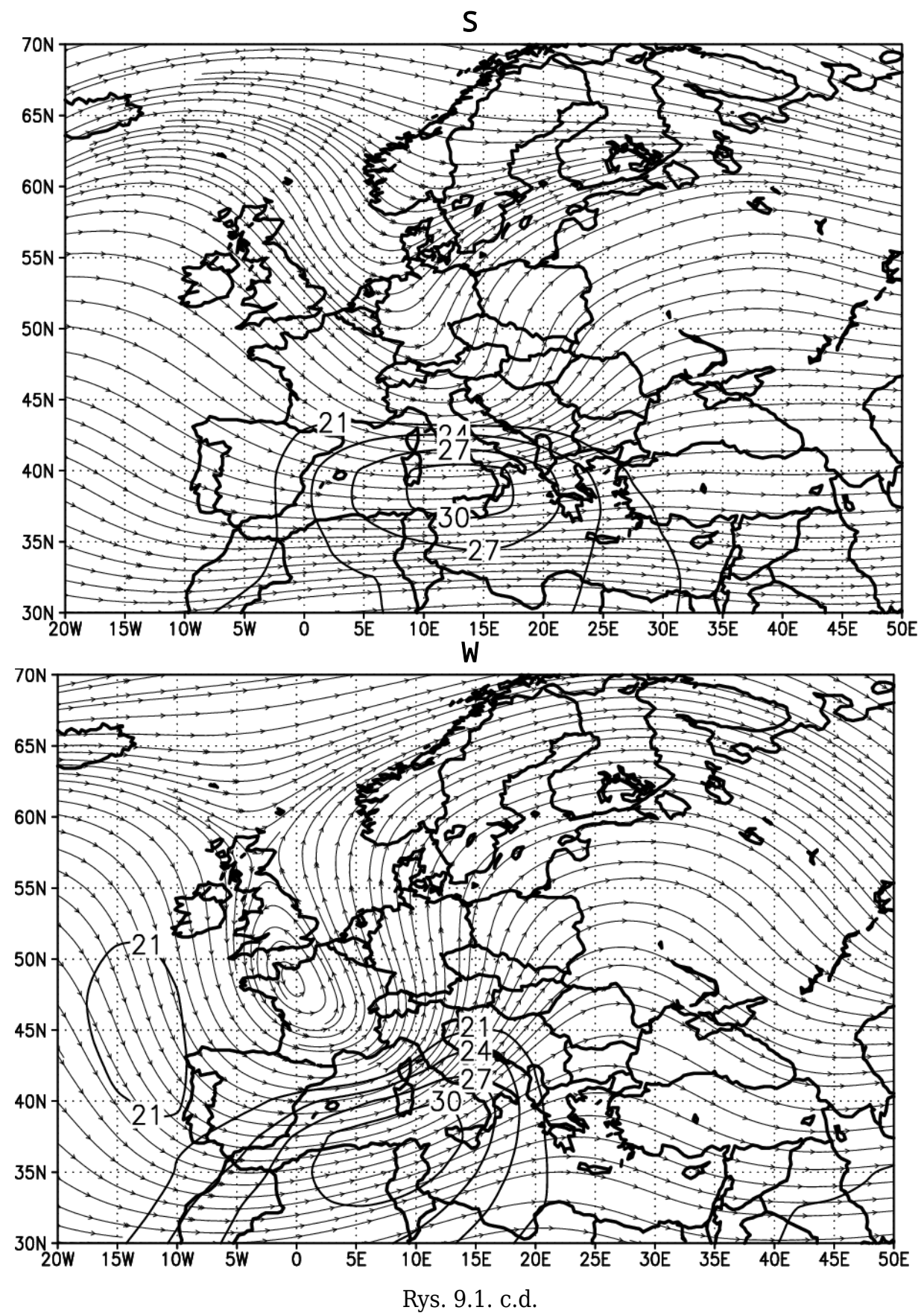

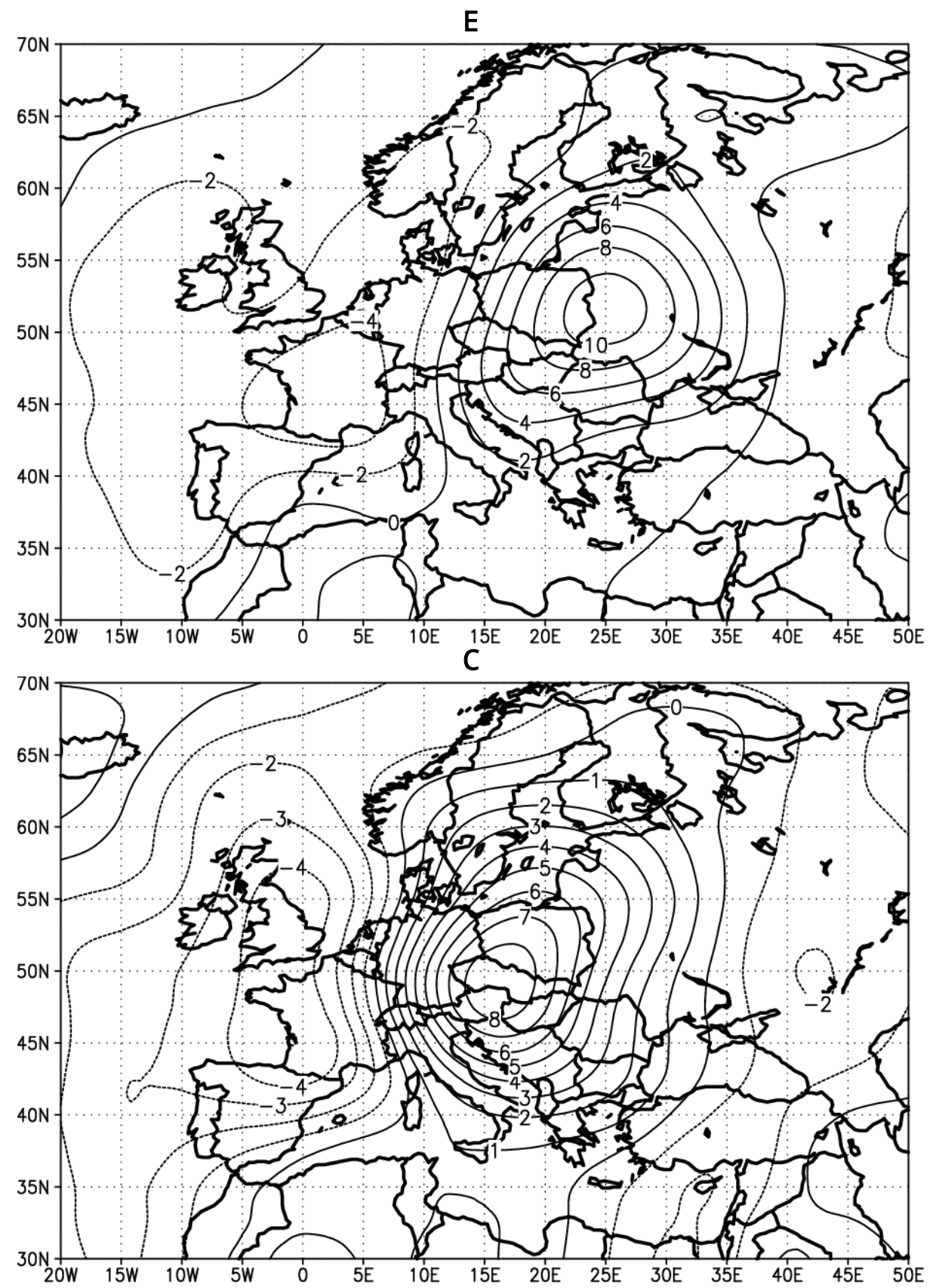

Rys. 9.2. Dywergencja $\left(\times 10^{-6} \mathrm{~s}^{-1}\right)$ na powierzchni $300 \mathrm{hPa}$ uśredniona w terminach występowania niżów $M E C$ na opadotwórczych odcinkach trajektorii E, C, S oraz W. Okres 1958-2008 (wg Degirmendžića i Kożuchowskiego, 2016) 

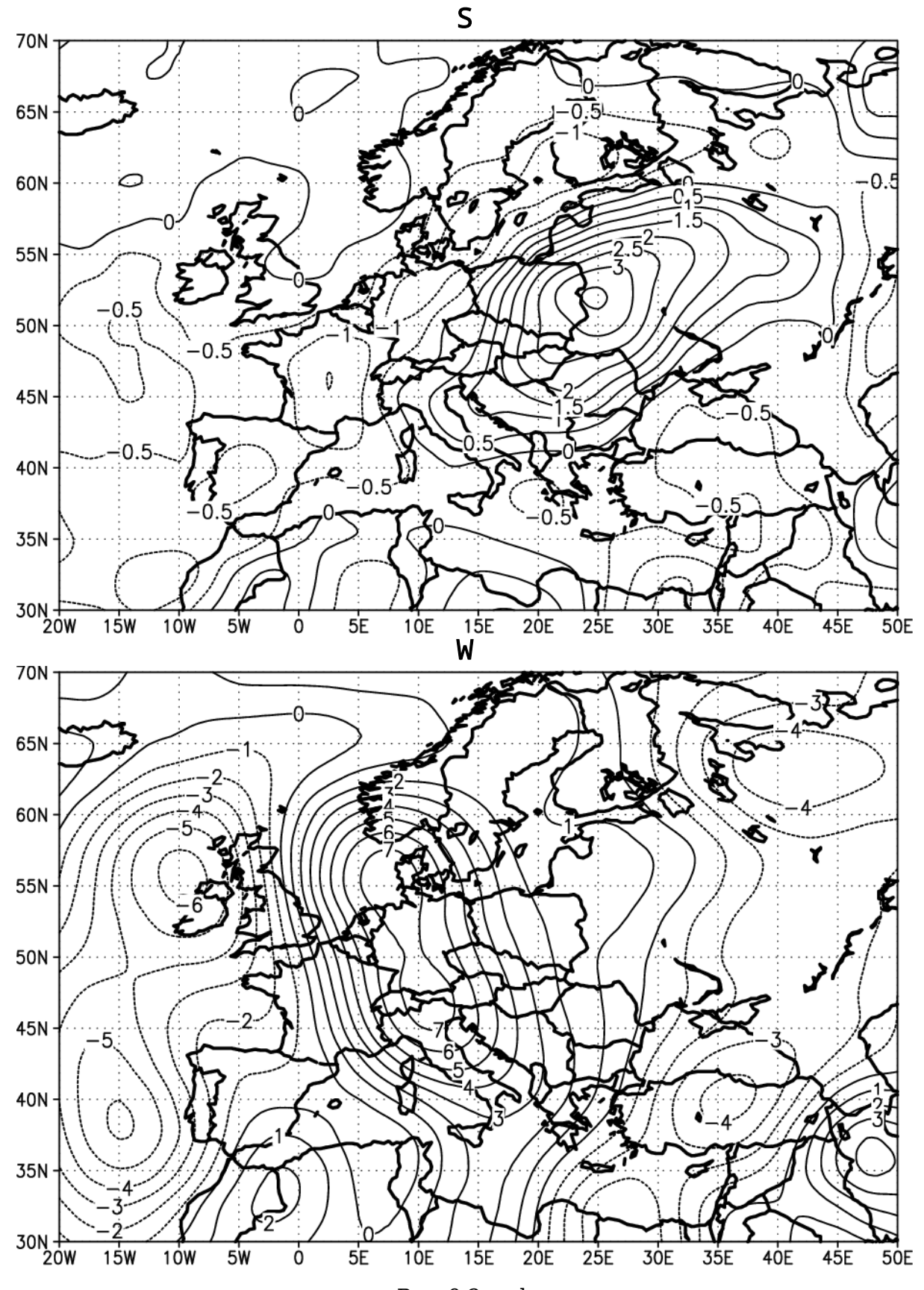

Rys. 9.2. c.d. 

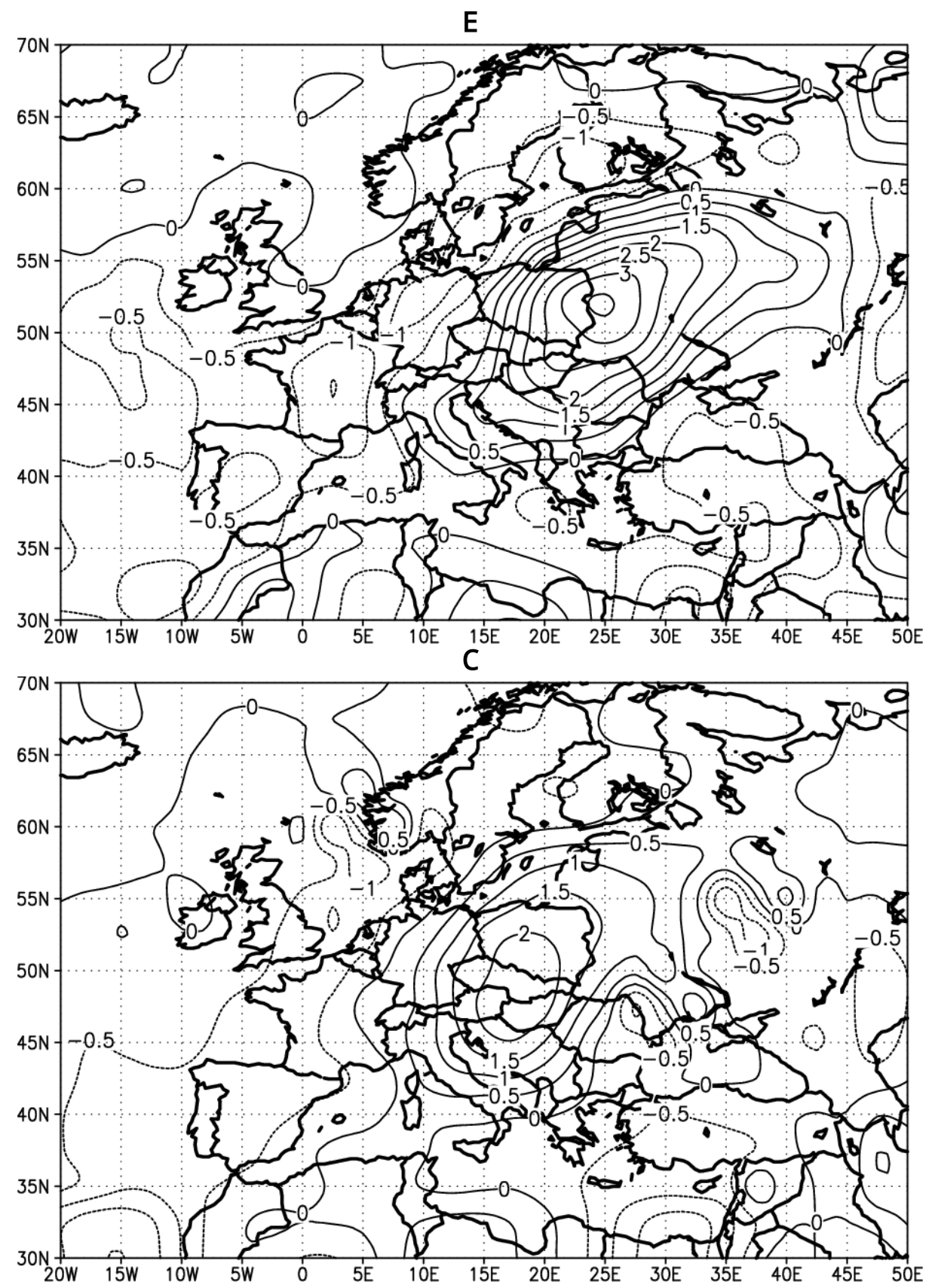

Rys. 9.3. Dywergencja związana z jet streak $\left(\times 10^{-6} \mathrm{~s}^{-1}\right)$ na powierzchni $300 \mathrm{hPa}$ uśredniona w terminach występowania niżów $M E C$ na opadotwórczych odcinkach trajektorii E, C, S oraz W. Okres 1958-2008 

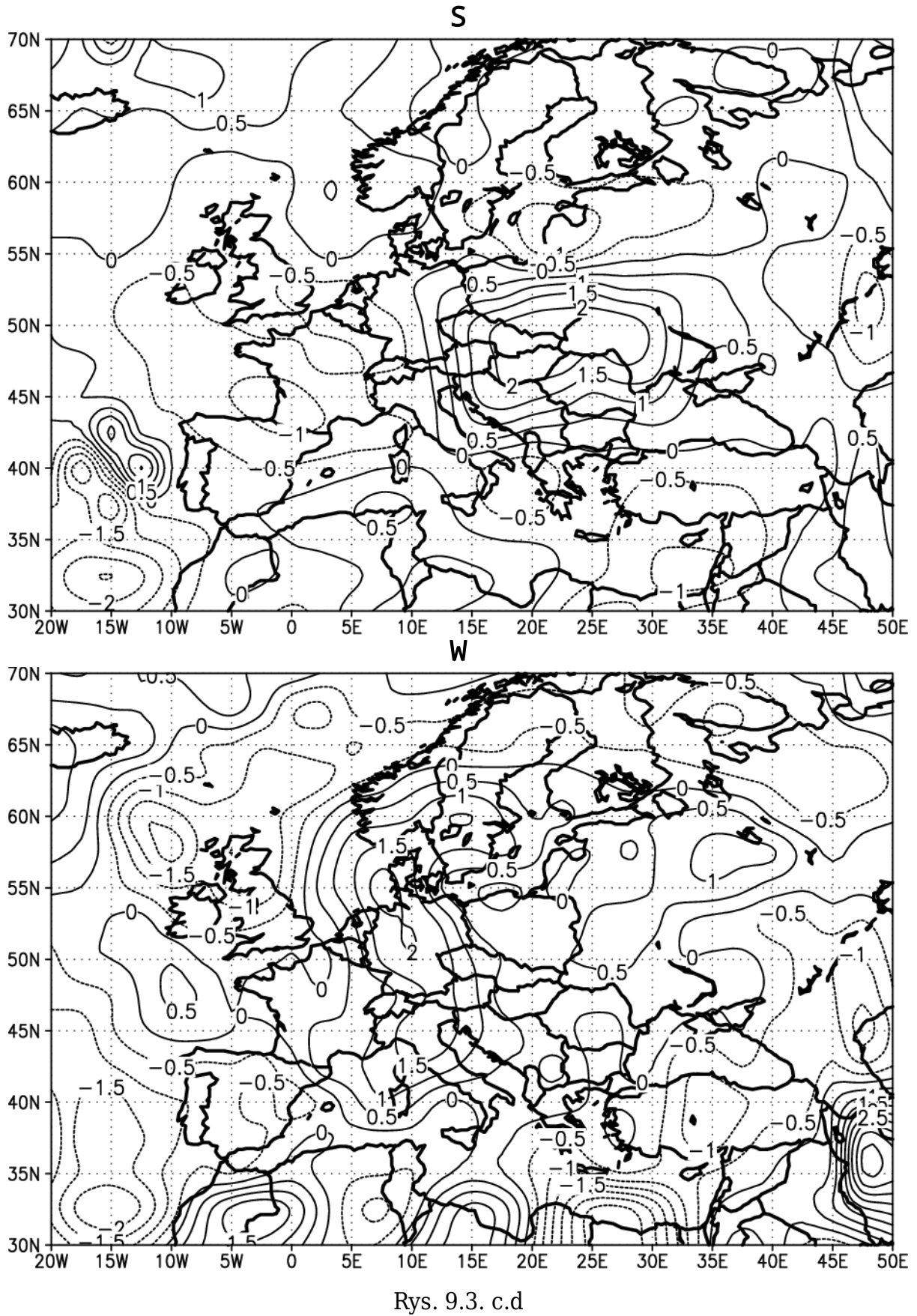


\section{Wnioski}

Górna zatoka nad zachodnią Europą (a w szczególności jej wschodnie skrzydło) oraz jet streak osadzony w pobliżu jej osi, w podzwrotnikowym prądzie strumieniowym, są istotnymi czynnikami, które sprzyjają rozwojowi niżów MEC na opadotwórczych odcinkach ich trajektorii. Nad odcinkami trajektorii E, C, W oraz S, w górnej troposferze rozwija się dodatnia dywergencja o średnich wartościach 7-10 $\times 10^{-6} \mathrm{~s}^{-1}$. Taki zakres dywergencji odpowiada klasie modalnej dywergencji charakterystycznej dla bomb rozwijających się nad obszarem Europy i wschodniego Atlantyku. Najwyższe wartości towarzyszą niżom klasy E (ok. $\left.10 \times 10^{-6} \mathrm{~s}^{-1}\right)$. Pole dywergencji związane z tą klasą MEC wynika w części ze sprzężenia dwóch jet streak, widocznych w STJ i PFJ, cechujących się odpowiednio cyklonalną i antycyklonalną krzywizną. Według niektórych scenariuszy zmian klimatu przewidywane przesunięcie atlantyckiego prądu strumieniowego ku wschodowi, nad kontynent Europy, może zmniejszyć istotnie częstość występowania sytuacji TrM (wg klasyfikacji Großwetterlagen) nad zachodnią i środkową Europą i w konsekwencji również ograniczyć liczbę MEC. 


\section{Rozdział 10 Podsumowanie i wnioski}

Wykonane opracowanie pozwala na rozstrzygnięcie postawionych na wstępie hipotez badawczych. Poniżej zamieszczono argumenty, potwierdzające te hipotezy (z jednym istotnym wyjątkiem) w kolejności, ustalonej w rozdziale 2:

1. Można uznać, że niże śródziemnomorskie należą do rzadkich układów cyrkulacyjnych w Europie Środkowej. Statystyki wyróżnionych niżów MEC potwierdzają, że częstość występowania niżów śródziemnomorskich nad Europą Środkowo-Wschodnią jest stosunkowo niewielka: rocznie notuje się przeciętnie 7 takich przypadków, a prawdopodobieństwo wystąpienia $w$ danym dniu roku niżu śródziemnomorskiego nie sięga $\mathbf{2 \%}$.

2. Stwierdzono, że częstość występowania $M E C$ charakteryzuje się sezonową zmiennością. Zmienność ta charakteryzuje się półroczną cyklicznością z maksimami w kwietniu i październiku. Maksimum wiosenne jest najbardziej rozwinięte. Niże śródziemnomorskie stosunkowo rzadko zdarzają się w lipcu, chociaż wtedy ryzyko związanych z nimi skrajnie wysokich opadów atmosferycznych w środkowej Europie jest szczególnie duże.

3. Niże MEC docierają do Europy Środkowej i Środkowo-Wschodniej charakterystycznymi, ale zróżnicowanymi trajektoriami. Wydzielono szereg klas (typów) tych trajektorii. Niże pochodzące znad basenu Morza Śródziemnego najczęściej wykorzystują szlak typu C - przechodzący centralnie przez Polskę. Dość wysoką frekwencją charakteryzuje się też szlak biegnący na wschód od Polski (typ E), który w przybliżeniu odpowiada torowi $\mathrm{Vb}$, wskazanemu przez van Bebbera.

4. Opady pochodzenia śródziemnomorskiego w Polsce wyróżniają się dużą obfitością i stanowią znaczącą część całkowitej sumy opadów. Analizując wartości średnie stwierdzono względną przewagę obfitości opadów MCP w relacji do średniej obfitości opadów w Polsce. Udział MCP 
w całkowitej sumie opadów w Polsce można uznać za wysoki po uwzględnieniu niewielkiej częstości występowania niżów MEC. Średnia obfitość „opadów śródziemnomorskich” (wysokość opadu MCP/dzień z opadem) stanowi około $150 \%$ średniej obfitości wszystkich opadów w Polsce. Opady związane z działalnością niżów śródziemnomorskich stanowią średnio około $10 \%$ całkowitej wysokości opadów atmosferycznych występujących w Polsce. W kwietniu (6-10.04) opady śródziemnomorskie stanowią blisko 1/3 całkowitych sum opadów w Polsce. Udział opadów MCP w całkowitych sumach opadowych wzrasta wraz z wysokością tych sum. Opady dobowe o wysokości $>80 \mathrm{~mm}$ składają się średnio prawie $\mathrm{w} \mathbf{1} / \mathbf{z}$ opadów $M C P$.

5. Rozkład przestrzenny $M C P$ na obszarze Polski zależy od trajektorii przemieszczania się $M E C$. Wyższe od przeciętnej obfitości całkowitych opadów są te opady $M C P$, które wiążą się z niżami, wędrującymi znad Morza Śródziemnego przez obszar Polski (klasa C), na wschód (klasa niżów E) oraz na południe od granic kraju (klasa niżów S). Najwyższe opady MCP występują po lewej (zachodniej) stronie południkowo biegnących szlaków CW, CE i E, w strefach panowania składowej północnej i wschodniej cyrkulacji cyklonalnej. Na południowym wschodzie Polski najwyższe MCP wiążą się też ze szlakiem niżów klasy S - występują na północ od tego szlaku. O porządku przestrzennym rozkładu opadów MCP na obszarze Polski decyduje w szczególności trajektoria przemieszczania się niżów na szlaku centralnym. Najwyższe średnie sumy MCP (>10 mm/dzień) występują w górach i na ich przedpolu, przy czym w Karpatach związane są one z działalnością MEC na szlakach wschodnim i południowym, w Sudetach - z niżami na szlakach centralnych CW i CE. Można więc wnioskować, że zagrożenie najwyższymi opadami w dorzeczu Odry wiąże się z niżami MEC na szlaku centralnym, w dorzeczu Wisły - z niżami na szlakach wschodnim i południowym.

6. Opady $M C P$ formują się $\mathrm{w}$ warunkach podwyższonej, ponadprzeciętnej zawartości wilgoci w atmosferze. Okazuje się jednak, że wpływ zawartości wilgoci w atmosferze na wysokość opadów nie jest zbyt wielki. Pod wpływem niżów śródziemnomorskich zawartość wilgoci $w$ atmosferze nad Polską wzrasta średnio o około 15\%; największy średni przyrost PW powodują niże wędrujące szlakiem zachodnim (22\%), najmniejszy - niże ze szlaku wschodniego (5\%). Średnie dobowe sumy opadów związanych z MEC stanowią średnio od 11\% (opady związane z zachod- 
nim szlakiem) do $37 \%$ (opady niżów ze szlaku wschodniego) średniej zawartości wilgoci $w$ atmosferze. Skrajnie wysokie opady MCP stanowią jednakże wielokrotność słupa wilgoci atmosferycznej - mogą przewyższać go nawet 8-9 razy. Wszystkie zidentyfikowane opady $M C P$ wykazują istotną, ale niezbyt silną korelację z zawartością wilgoci. Zmiany zawartości wilgoci wyjaśniają jedynie $10 \%$ zmienności sum MCP. Niże MEC sterują napływem wilgoci znad Morza Śródziemnego i formują „plamę” wilgoci zlokalizowaną nad Polską i na wschód od jej obszaru wskutek mającej tam miejsce konwergencji strumieni wilgoci.

7. Niże $M E C$ i związane $\mathrm{z}$ nimi wysokie opady pojawiają się $\mathrm{w}$ okresach panowania południkowych makroform cyrkulacji atmosferycznej. Niże w basenie Morza Śródziemnego oraz MEC na opadotwórczych odcinkach ich szlaków w Europie są najczęściej związane z makroformą cyrkulacji południkowej $E$ (ponad 2/3 występuje $w$ dniach panowania makroformy E). Związek niżów MEC z makroformą cyrkulacji E znajduje potwierdzenie $w$ wieloletnim przebiegu ich zmian. Korelacja rocznej częstości MEC i makroform $E$ jest istotna, choć niezbyt wysoka $(r=0,33)$. Przypadający na lata 1980. spadek frekwencji MEC zbiega się $\mathrm{z}$ malejącą frekwencją makroform $\mathrm{E}$. W ciągu półwiecza roczna liczba niżów MEC zmniejszyła się o ponad połowę, liczba dni z makroformą E - o 35\%. Niżom MEC towarzyszy zarazem charakterystyczne zróżnicowanie temperatur nad Europą, świadczące o panowaniu południkowych form cyrkulacji. Średnie wartości różnic temperatury w przekroju równoleżnikowym niżów wynoszą około $7^{\circ} \mathrm{C}$. Temperatura przyziemnych warstw powietrza wzrasta $\mathrm{z}$ zachodu na wschód. Wysokość opadów pochodzenia śródziemnomorskiego $w$ Polsce wykazuje słabe korelacje $\mathrm{z}$ intensywnością adwekcji chłodu, tj. $\mathrm{z}$ ujemnymi anomaliami temperatury na zachodnich peryferiach niżów MEC.

Wykazano, że do rozwoju aktywności niżów MEC na opadotwórczych odcinkach ich trajektorii przyczyniają się w szczególności warunki cyrkulacyjne w górnej troposferze: górna zatoka nad zachodnią Europą oraz jet streak osadzony w pobliżu jej osi, w podzwrotnikowym prądzie strumieniowym. Nad odcinkami trajektorii $E, C$, $W$ oraz $S$ panuje silna dodatnia dywergencja o średnich wartościach charakterystycznych dla bomb rozwijających się nad obszarem Europy i wschodniego Atlantyku. Najwyższe wartości dywergencji towarzyszą niżom klasy E. 
8. Niże $M E C$ i opady $M C P$ należą do klasy ekstremalnych zjawisk hydrometeorologicznych, a ich częstość i intensywność wzrasta wraz z postępującym globalnym ociepleniem klimatu. Niektóre absolutne maksima sum dobowych opadów w Polsce mają genezę śródziemnomorską. Rozlewne opady i powodzie, związane z aktywnością MEC, obok względnie małej częstości występowania tych sytuacji synoptycznych, pozwalają na ich zaliczenie do klasy zjawisk ekstremalnych.

W wieloleciu 1958-2008 zmalała całkowita liczba zidentyfikowanych niżów śródziemnomorskich, docierających do Europy ŚrodkowoWschodniej. Roczna liczba MEC wykazuje istotny trend zniżkowy $(-3,7$ w okresie 50 lat przy średniej 6,9). Największy ubytek częstości dotyczy niżów wędrujących torem wschodnim ( Vb). W analizowanym okresie roczne sumy MCP w Polsce zmniejszyły się o 29 mm, co stanowi $43 \%$ ich średniej wieloletniej wysokości. Trendy opadowe wskazują na malejący udział MCP w sumie całkowitych opadów w Polsce. Wieloletni przebieg zawartości wilgoci w atmosferze nad Polską charakteryzuje się również tendencją malejącą. W okresie 1958-2008 średnie roczne wartości PW zmalały o prawie $10 \%$ i była to zmiana statystycznie istotna.

Jeśli MEC, a zwłaszcza związane $\mathrm{z}$ nimi wysokie opady atmosferyczne zaliczyć można do kategorii zjawisk ekstremalnych, to hipoteza o rosnącej częstości tych zjawisk w epoce współczesnego ocieplenia klimatu, w świetle przeprowadzonych analiz, nie znajduje potwierdzenia. Malejąca częstość makroform cyrkulacji, sprzyjających niżom śródziemnomorskim docierającym do Europy Środkowo-Wschodniej, stanowi prawdopodobne wyjaśnienie obserwowanych trendów częstości MEC i wysokości sum MCP. Należy jednakże dodać, że przy malejącej częstości niżów MEC i malejącej zawartości wilgoci w atmosferze, obfitość opadów MCP utrzymywała się w ciągu badanego wielolecia na nie zmienionym znacząco poziomie, $\mathrm{z}$ czego wynika, że efektywność procesów opadodotwórczych w niżach $M E C$ mogła wzrastać.

Według niektórych scenariuszy zmian klimatu przewidywane przesunięcie atlantyckiego prądu strumieniowego ku wschodowi, nad kontynent Europy, może zmniejszyć istotnie częstość występowania sytuacji TrM (wg klasyfikacji Großwetterlagen) nad zachodnią i środkową Europą i w konsekwencji również ograniczyć liczbę MEC.

Niże śródziemnomorskie w Europie Środkowo-Wschodniej, jak i opady o genezie śródziemnomorskiej oraz zawartość wilgoci w atmosferze nad Pol- 
ską podlegają niewątpliwie oddziaływaniu zmian globalnych. Należy jednak zauważyć, iż bezpośrednim czynnikiem tych oddziaływań jest cyrkulacja atmosferyczna i jej przekształcenia w skali hemisferycznej, których rezultatem są zarówno obserwowane trendy niżów śródziemnomorskich i opadów pochodzenia śródziemnomorskiego, jak i znaczący trend zawartości wilgoci w atmosferze, w Polsce malejący - wbrew postępom ocieplenia. 



\section{Spis tabel}

Tab. 4.1. Liczba niżów śródziemnomorskich w Europie Środkowo-Wschodniej w latach 1958-2008 (wg Degirmendžića i Kożuchowskiego, 2014) 36

Tab. 4.2. Udział miesięcznej liczby niżów śródziemnomorskich w ich liczbie rocznej (\%) oraz współczynniki nierównomierności miesięcznych częstości niżów (Vn) (wg Degirmendžića i Kożuchowskiego, 2014) ....

Tab. 4.3. Współczynniki korelacji miesięcznych częstości niżów śródziemnomorskich i harmoniki półrocznej (r6) oraz rocznej (r12) (wg Degirmendžića i Kożuchowskiego, 2014)

Tab. 4.4. Prawdopodobieństwo empiryczne dnia z niżem śródziemnomorskim MEC (w \%) i z niżem typu centralnego (C) w poszczególnych miesiącach oraz w ciągu roku (I-XII) (wg Degirmendžića i Kożuchowskiego, 2014)

Tab. 5.1. Średnie sezonowe i roczne sumy opadów o genezie śródziemnomorskiej (MCP), całkowite sumy opadów i udział MCP w całkowitych sumach opadów na obszarze Polski, na obszarach górskich i przedgórskich oraz w pozostałej części Polski (1958-2008) (wg Degirmendžića i Kożuchowskiego, 2015a)

Tab. 5.2. Całkowita liczba dni z opadem, liczba dni z opadem MCP i obfitość tych opadów [mm/doba] (wg Degirmendžića i Kożuchowskiego, 2015a)

Tab. 5.3. Ilorazy obfitości opadów MCP i pozostałej części opadów (wg Degirmendžića i Kożuchowskiego, 2015a)

Tab. 6.1. Średnie dobowe wysokości opadów śródziemnomorskich $(\mathrm{mm})$ i wskaźniki ich efektywności (\%) w zależności od klasy szlaku niżów śródziemnomorskich (wg Degirmendžića i Kożuchowskiego, 2015c)

Tab. 6.2. Średnia obfitość całkowitych opadów atmosferycznych w wybranych stacjach [mm/dzień], średnie dobowe sumy opadów śródziemnomorskich w zależności od typu szlaku niżów śródziemnomorskich oraz wskaźnikowe typy szlaków związanych $\mathrm{z}$ najwyższą $\left(M C P_{\mathrm{MAX}}\right)$ oraz $\mathrm{z}$ wyższą od średniej (Ie $>100 \%$ ) obfitością opadów śródziemnomorskich (wg Degirmendžića i Kożuchowskiego, 2015c)

Tab. 7.1. Rozkład zawartości wody opadowej w atmosferze (PW) związanej z opadami o dużym natężeniu w Gdyni (wg Malinowskiej i Miętusa, 2010). ... 77

Tab. 7.2. Zawartość wilgoci w atmosferze nad Polską (PW) w dniach występowania $M E C$ na opadotwórczych odcinkach szlaków W, C, S, E oraz jej wartości wieloletnie (1958-2008) (wg Degirmendžića i Kożuchowskiego, 2015b) 
Tab. 7.3. Średnia obfitość MCP (DP) i średnia zawartość wilgoci nad Polską (PW) w zależności od toru $M E C$, średnia wieloletnia obfitość całkowitych opadów w Polsce (DP-PL) oraz średnie wieloletnie zawartości wilgoci (PW-PL) oraz współczynnika DP/PW (wg Degirmendžića i Kożuchowskiego, 2015b)

Tab. 7.4. Średnie anomalie zawartości wilgoci w atmosferze nad Polską $(\Delta \mathrm{PW})$ oraz współczynniki korelacji prostej (r) i cząstkowej ( $\left.r^{*}\right)$ wysokości opadów $M C P$ i zawartości wilgoci w atmosferze $(\Delta \mathrm{PW})$. Anomalie obliczono jako różnice między wartościami średniej PW w dniach z niżami MEC na odcinkach opadotwórczych trajektorii oraz analogicznymi średnimi $\mathrm{z}$ wielolecia 1958-2008

Tab. 7.5. Obfitość (DP) najwyższych opadów dobowych i odpowiadająca im zawartość wilgoci w atmosferze (PW), jej względne odchylenia od średniej wieloletniej $(\Delta)$ oraz ilorazy DP/PW (wg Degirmendžića i Kożuchowskiego, 2015b)

Tab. 7.6. Średnie anomalie temperatury w obszarach położonych na zachód (ТzACH) i na wschód (Twsch) od szlaków niżów $M E C$, ich różnice (TzAcH-Twsch) $\left[{ }^{\circ} \mathrm{C}\right]$ oraz współczynniki korelacji (r) wysokości opadów $M C P \mathrm{w}$ Polsce $\mathrm{z}$ anomaliami temperaturami TzACH, Twsch i różnicą TzACH-Twsch . Zaznaczono współczynniki istotne na poz. 0,05

Tab. 8.1. Trendy sezonowych sum opadów w Europie w latach 1951-2010 [mm/10 lat] (wg Besselaar i in., 2012)

Tab. 8.2. Częstości MEC w latach 1958-2007. Średnie 10-letnie liczby dni w \% średniej 50-letniej oraz łączna średnia liczba dni z niżami MEC w 50-leciu ... 108

Tab. 8.3. Wartości średnie i współczynniki kierunkowe trendów (a/50 lat) parametrów $M E C$, sum i obfitości opadów w Polsce, zawartości wilgoci w atmosferze nad Polską oraz liczby dni z makroformami cyrkulacji Vangengeima-Girsa (V-G). Wyróżniono współczynniki (p $\leq 0,05)$ (wg Degirmendžića i Kożuchowskiego, 2015b, zmienione)

Tab. 8.4. Częstość (w \%) makroform cyrkulacji Vangengeima-Girsa (V-G) w dniach z niżami $M E C$ w okresie 1958-2008 .......................................... 115

Tab. 8.5. Opady MCP i towarzyszące im makroformy cyrkulacji V-G .................... 117 


\section{Spis rysunków}

Rys. 1.1. Szlaki niżowe w Europie (wg van Bebbera, 1891)

10

Rys. 1.2. Szlak niżowy T7 i częstość występowania głębokich niżów na tym szlaku (wg Bielec-Bąkowskiej, 2010)

Rys. 3.1. Siatka równoleżników i południków wyznaczająca sektory Europy Środkowo-Wschodniej - W, E, S, N i C (wg Degirmendžića i Kożuchowskiego, 2014)

Rys. 3.2. Stacje meteorologiczne wykorzystane w opracowaniu. Stacje górskie i przedgórskie oznaczono czarnymi kropkami (wg Degirmendžića i Kożuchowskiego, 2015a)

Rys. 4.1. Trajektorie niżów śródziemnomorskich typu C1. Zaznaczono miejsca cyklogenezy (puste koła) i cyklolizy (szare koła) (wg Degirmendžića i Kożuchowskiego, 2014)

Rys. 4.2. Trajektorie niżów śródziemnomorskich typu S1. Oznaczenia jak na rys. 4.1 (wg Degirmendžića i Kożuchowskiego, 2014)

Rys. 4.3. Trajektorie niżów śródziemnomorskich typu E2. Oznaczenia jak na rys. 4.1 (wg Degirmendžića i Kożuchowskiego, 2014)

Rys. 4.4. Miesięczne liczby niżów śródziemnomorskich w Europie Środkowo-Wschodniej w okresie 1958-2008 oraz ich półroczna składowa harmoniczna (wg Degirmendžića i Kożuchowskiego, 2014)

Rys. 5.1. Rozkład wartości ortodrom [km] określających odległość stacji, na której wystąpił opad $M C P$ od położenia centrum niżu śródziemnomorskiego (MEC). Okres 1958-2008 (wg Degirmendžića i Kożuchowskiego, 2015a)

Rys. 5.2. Średnie położenie toru Vb niżów śródziemnomorskich (MEC) oraz usytuowanie obszaru (okrąg o promieniu $250 \mathrm{~km}$ i środku w danym punkcie trajektorii), z którym związane są najwyższe opady MCP na obszarze Polski (wg Degirmendžića i in., 2014)

Rys. 5.3. Udział procentowy dobowych sum MCP w całkowitych sumach opadów na obszarze Polski: według decyli rozkładu sum dobowych (lewy wykres) i według przedziałów sum dobowych 0-10, 10-20, 20-30 mm itd. (przedziały prawostronnie domknięte; prawy wykres). Na prawym wykresie zaznaczono liczbę stacji meteorologicznych, na których zanotowano opad MCP (wg Degirmendžića i Kożuchowskiego, 2015a)

Rys. 5.4. Średni udział MCP [\%] w całkowitych sumach opadów rocznych i sezonowych na obszarze Polski w okresie 1958-2008 (wg Degirmendžića i Kożuchowskiego, 2015a) 
Rys. 5.5. Średnia roczna i sezonowa obfitość $M C P$ w Polsce [mm/doba] w okresie 1958-2008 (wg Degirmendžića i Kożuchowskiego, 2015a) ............................. 53

Rys. 5.6. Sumy miesięczne MCP [mm] w Polsce w sierpniu 1972 r. (wg Degirmendžića i Kożuchowskiego, 2015a)

Rys. 5.7. Średnie pentadowe sumy opadów $M C P$ (a) i całkowite sumy opadów na obszarze Polski (b) oraz udział $M C P$ w całkowitej sumie opadów (c). Dodano średnią ruchomą 7-elementową (wg Degirmendžića i Kożuchowskiego, 2015a)

Rys. 6.1. Średnie położenie szlaku wschodniego (E) niżów śródziemnomorskich. Punkty trajektorii ponumerowano zgodnie z kierunkiem ruchu niżów. Linią pogrubioną oznaczono opadotwórczy odcinek trajektorii (wg Degirmendžića i Kożuchowskiego, 2015c)

Rys. 6.2. Średnie dobowe wysokości opadów $M C P$ [mm] w Polsce w zależności od położenia ośrodków niżów $M E C$ na szlaku wschodnim. Linia czerwona oznacza najwyższe średnie dobowe w Polsce, linia czarna - średnie obszarowe sumy opadów na obszarze Polski. Pole zaciemnione odpowiada opadotwórczemu odcinkowi szlaku (wg Degirmendžića i Kożuchowskiego, 2015c) .. 62

Rys. 6.3. Średnie dobowe sumy $M C P[\mathrm{~mm}]$ na obszarze Polski, odpowiadające położeniu niżów $M E C$ na opadotwórczym odcinku szlaku wschodniego (wg Degirmendžića i Kożuchowskiego, 2015c)

Rys. 6.4. Średnie położenie szlaku centralnego (C) niżów śródziemnomorskich z gałęziami wschodnią (CE) i zachodnią (CW). Oznaczenia - jak na rys. 6.1 (wg Degirmendžića i Kożuchowskiego, 2015c)

Rys. 6.5. Średnie dobowe wysokości opadów $M C P$ [mm] w Polsce w zależności od położenia ośrodków niżów $M E C$ na szlaku centralnym. Linia czerwona oznacza najwyższe średnie dobowe w Polsce, linia czarna - średnie obszarowe sumy opadów na obszarze Polski (linie przerywane - odpowiednio opady związane z położeniem niżów na wschodniej gałęzi szlaku). Pole zaciemnione odpowiada opadotwórczemu odcinkowi szlaku centralnego, szraf dotyczy opadotwórczego odcinka wschodniej gałęzi szlaku (wg Degirmendžića i Kożuchowskiego, 2015c)

Rys. 6.6. Średnie dobowe sumy opadów $M C P$ [mm] na obszarze Polski, odpowiadające położeniu niżów $M E C$ na opadotwórczych odcinkach szlaku centralnego - CE (lewa mapa) i CW (prawa mapa) (wg Degirmendžića i Kożuchowskiego, 2015c)

Rys. 6.7. Średnie położenie szlaku zachodniego (W) niżów śródziemnomorskich z gałęzią wschodnią (WE) i zachodnią (WW). Oznaczenia jak na rys. 6.1 (wg Degirmendžića i Kożuchowskiego, 2015c)

Rys. 6.8. Średnie dobowe wysokości opadów $M C P$ [mm] w Polsce w zależności od położenia ośrodków niżów MEC na szlaku zachodnim. Oznaczenia jak na rys. 6.5 (wg Degirmendžića i Kożuchowskiego, 2015c)

Rys. 6.9. Średnie dobowe sumy opadów $M C P$ [mm] na obszarze Polski, odpowiadające położeniu niżów MEC na opadotwórczych odcinkach szlaku zachodniego - WE (lewa mapa) i WW (prawa mapa) (wg Degirmendžića i Kożuchowskiego, 2015c)

Rys. 6.10. Średnie położenie szlaku południowego (S) niżów śródziemnomorskich. Oznaczenia jak na rys. 6.1 (wg Degirmendžića i Kożuchowskiego, 2015c) 
Rys. 6.11. Średnie dobowe wysokości opadów $M C P$ [mm] w Polsce w zależności od położenia ośrodków niżów $M E C$ na szlaku południowym. Oznaczenia jak na rys. 6.2 (wg Degirmendžića i Kożuchowskiego, 2015c)

Rys. 6.12. Średnie dobowe sumy opadów $M C P$ [mm] na obszarze Polski, odpowiadające położeniu niżów MEC na opadotwórczym odcinku szlaku południowego (wg Degirmendžića i Kożuchowskiego, 2015c)

Rys. 6.13. Wskaźnik efektywności najwyższych średnich opadów MCP w Polsce (wg Degirmendžića i Kożuchowskiego, 2015c)

Rys. 6.14. Zasięgi występowania najwyższych średnich dobowych opadów $M C P$ w Polsce, odpowiadających szlakom E, CE, CW i S (wg Degirmendžića i Kożuchowskiego, 2015c)

Rys. 6.15. Zasięgi występowania efektywnych opadów MCP (Ie>100\%) na obszarze Polski, związanych z położeniem MEC na szlaku południowym (S), wschodnim (E), oraz centralnym (CE i CW) (wg Degirmendžića i Kożuchowskiego, 2015c)

Rys. 7.1. Roczny przebieg średniej pentadowej obfitości opadów w Polsce (DP w mm/dobę, słupki) i średniej pentadowej zawartości wilgoci w atmosferze (PW w mm, kreski) oraz ich składowe harmoniczne

Rys. 7.2. Roczny przebieg stosunku obfitości opadów w Polsce do zawartości wilgoci w atmosferze (DP/PW) - średnie wartości w pentadach (kreski) oraz suma głównych składowych harmonicznych

Rys. 7.3. Lewy panel: średnie położenie szlaków niżów śródziemnomorskich $(M E C)$ przemieszczających się nad Europą Środkowo-Wschodnią. E - szlak wschodni (niebieski), C - szlak centralny (z gałęziami CW i CE; czarny), W - szlak zachodni (z gałęziami WW i WE; zielony), S - szlak południowy (czerwony). Prawy panel: średnie trajektorie niżów czarnomorskich typu BS (BSN - trajektoria północna, BSC - centralna, BSS - południowa, BSE - wschodnia). Numeracja punktów na trajektorii zgodnie z ruchem $M E C$

Rys. 7.4. Przebieg anomalii dobowych wartości PW nad Polską uśrednionych względem terminu wystąpienia niżów $M E C$ na opadotwórczych odcinkach szlaku E, C, W i S

Rys. 7.5. Średni opad $M C P$ [mm] versus odchylenia PW [mm] od cyklu rocznego w terminach kiedy $M E C$ usytuowane były na opadotwórczych odcinkach trajektorii E, C, W oraz S w okresie 1958-2008. Wartości MCP oraz PW uśredniono dla obszaru Polski. Przedstawiono linię regresji wraz z równaniem i współczynnikiem determinacji $\left(\mathrm{R}^{2}\right)$

Rys. 7.6. Najwyższe sumy dobowe opadów w Polsce $\left(\mathrm{P}_{\mathrm{MAX}}\right)$ w zależności od odchyleń zawartości wilgoci w atmosferze ( $\Delta$-Delta). Uwzględniono 100 przypadków maksymalnych opadów dobowych z lat 1958-2008. $\Delta$ - względne odchylenie zawartości wilgoci (PW) od średniej wieloletniej PW z dnia wystąpienia opadu $\mathrm{P}_{\mathrm{MAX}}$

Rys. 7.7. Rozkład częstości odchyleń dobowych wartości PW ( $\Delta$-delta) w dniach występowania maksymalnych opadów w Polsce. Objaśnienia jak na rys. 7.6 
Rys. 7.8. Rozkład średnich dobowych zawartości wilgoci w atmosferze nad Polską w okresie 1958-2008 (PW - niebieski) oraz rozkład zawartości wilgoci w terminach wystąpienia 100 przypadków ekstremalnych opadów dobowych (czerwony)

Rys. 7.9. Anomalie słupa wody opadowej (PW) w Eurazji [mm]. Anomalie obliczono jako różnice między wartościami średniej $\mathrm{PW}$ w dniach z niżami $M E C$ na odcinkach opadotwórczych trajektorii W, C, S i E oraz analogicznymi średnimi z wielolecia 1958-2008

Rys. 7.10. Anomalie strumieni wilgoci uśrednione w terminach kiedy niże $M E C$ wystąpiły na opadotwórczym odcinku trajektorii E w okresie 1958-2008. Objaśnienia procedury liczenia anomalii jak na rys. 7.9

Rys. 7.11. Zachmurzenie związane z niżem MEC nad Polską (wg zbiorów Katedry Klimatologii UŚ)

Rys. 7.12. Konwergencja strumieni wilgoci $\left[\times 10^{-4} \mathrm{~g} \mathrm{~kg}^{-1} \mathrm{~s}^{-1}\right]$ uśredniona w terminach kiedy niże $M E C$ występowały na opadotwórczym odcinku trajektorii E w okresie 1958-2008

Rys. 7.13. Anomalie temperatury powietrza $\left[{ }^{\circ} \mathrm{C}\right]$ na wys. $2 \mathrm{~m}$ npt. uśrednione w terminach kiedy $M E C$ występowały na opadotwórczym odcinku trajektorii E w okresie 1958-2008. Objaśnienia procedury liczenia anomalii jak na rys. 7.9

Rys. 7.14. Rozkłady częstości średniej temperatury w zachodniej (niebieski) i wschodniej Europie (czerwony) w okresie występowania $M E C$ na opadotwórczym odcinku toru E. Przedziały o rozpiętości $2^{\circ} \mathrm{C}$. Sektory, w granicach których uśredniono wartości temperatury jak na rys. 7.15

Rys. 7.15. Rozkłady anomalii średniej obszarowej temperatury na wys. $2 \mathrm{~m}$ n.p.t. w gridzie $2^{\circ}-14^{\circ} \mathrm{E} ; 43^{\circ}-52^{\circ} \mathrm{N}$ ( TzACH - niebieski) oraz gridzie $27^{\circ}-37^{\circ} \mathrm{E}$; $45^{\circ}-52^{\circ} \mathrm{N}$ ( Twsch - czerwony) w terminach kiedy MEC wystąpiły na opadotwórczym odcinku trajektorii E w okresie 1958-2008. Wyeliminowano cykl roczny z serii temperatury. Przedziały o rozpiętości $2^{\circ} \mathrm{C}$

Rys. 7.16. Rozkłady anomalii średniej obszarowej temperatury na wys. $2 \mathrm{~m}$ n.p.t. $\mathrm{W}$ gridzie $5^{\circ} \mathrm{W}-10^{\circ} \mathrm{E} ; 40^{\circ}-50^{\circ} \mathrm{N}$ ( TzACH - niebieski) oraz gridzie $22^{\circ}-31^{\circ} \mathrm{E}$; $41^{\circ}-52^{\circ} \mathrm{N}$ ( Twsch - czerwony) w terminach kiedy MEC wystąpiły na opadotwórczym odcinku trajektorii C w okresie 1958-2008. Dalsze objaśnienia jak na rys. 7.15

Rys. 7.17. Rozkłady anomalii średniej obszarowej temperatury na wys. 2 m n.p.t. w gridzie $10^{\circ} \mathrm{W}-0^{\circ} \mathrm{E} ; 35^{\circ}-45^{\circ} \mathrm{N}$ ( TzACH - niebieski) oraz gridzie $13^{\circ}-25^{\circ} \mathrm{E}$; $48^{\circ}-55^{\circ} \mathrm{N}$ ( Twsch - czerwony) w terminach kiedy MEC wystąpiły na opadotwórczym odcinku trajektorii W w okresie 1958-2008. Dalsze objaśnienia jak na rys. 7.15

Rys. 7.18. Rozkłady anomalii średniej obszarowej temperatury na wys. 2 m n.p.t. W gridzie $4^{\circ} \mathrm{W}-10^{\circ} \mathrm{E} ; 41^{\circ}-52^{\circ} \mathrm{N}$ ( TzAcH - niebieski) oraz gridzie $21^{\circ}-33^{\circ} \mathrm{E}$; $38^{\circ}-49^{\circ} \mathrm{N}$ ( Twsch - czerwony) w terminach kiedy MEC wystąpiły na opadotwórczym odcinku trajektorii S w okresie 1958-2008. Dalsze objaśnienia jak na rys. 7.15 
Rys. 7.19. Średni opad $M C P$ w Polsce [mm] versus odchylenia temperatury na zachodzie Europy [Tzach, ${ }^{\circ} \mathrm{C}$ ]. Przedstawiono odchylenia temperatury od cyklu rocznego w terminach kiedy niże $M E C$ usytuowane były na opadotwórczych odcinkach trajektorii E, C, W oraz S w okresie 1958-2008. Sektory Europy Zachodniej jak na rys. 7.15-7.18. Wartości $M C P$ uśredniono dla obszaru Polski. Przedstawiono linię regresji wraz z równaniem i współczynnikiem determinacji $\left(\mathrm{R}^{2}\right)$

Rys. 7.20. Średni opad MCP w Polsce [mm] versus różnice temperatury po zachodniej i wschodniej stronie szlaków niżowych $\left[{ }^{\circ} \mathrm{C}\right]$ (Тzach-Twsch). Dalsze objaśnienia jak na rys. 7.19

Rys. 8.1. Roczne częstości makroformy cyrkulacji W, E, C (wg Vangengeima-Girsa) i epoki cyrkulacyjne od 1891 do 2001 roku. Dla zwiększenia czytelności wykresu wartość 50 dodano do częstości makroformy W oraz odjęto od częstości makroformy C (wg Sepp'a, 2011) ...

Rys. 8.2. Wielkość zmian rocznych sum opadów [mm] w Polsce w okresie 1961-2008 (wg Marosza i in., 2011) ......

Rys. 8.3. Roczna liczba niżów śródziemnomorskich nad Europą Środkowo-Wschodnią w okresie 1958-2008 oraz trend liniowy MEC (wg Degirmendžića i Kożuchowskiego, 2105b)

Rys. 8.4. Średnie roczne sumy opadów całkowitych w Polsce (linia pogrubiona, oś rzędnych po lewej) i opadów MCP w okresie 1958-2008 (wg Degirmendžića i Kożuchowskiego, 2015b)

Rys. 8.5. Średnia roczna obfitość opadów całkowitych w Polsce (linia pogrubiona, oś rzędnych po lewej) i obfitość opadów MCP w okresie 1958-2008 (wg Degirmendžića i Kożuchowskiego, 2015b)

Rys. 8.6. Średnia roczna zawartość wilgoci w atmosferze nad Polską (PW) w latach 1958-2008 oraz trend liniowy PW (wg Degirmendžića i Kożuchowskiego, 2015b)

Rys. 8.7. Położenie fal długich na półkuli północnej w makroformach cyrkulacji

E, C i W (wg Vangengeima-Girsa, za A. A. Marsz, 2013)

Rys. 8.8. Roczna liczba niżów śródziemnomorskich MEC (czarna krzywa) i roczna liczba dni z makrotypem cyrkulacji E (czerwona) w okresie 1958-2008

Rys. 8.9. Roczne liczby dni z makroformami cyrkulacji E (kolor czarny), W (kolor czerwony) i C (kolor zielony) w latach 1958-2008

Rys. 8.10. Średnie pole geopotencjału powierzchni $500 \mathrm{hPa}[\mathrm{m}] \mathrm{w}$ terminach, w których niże $M E C$ znajdowały się na opadotwórczych odcinkach torów $\mathrm{E}$, C, W, S. Okres 1958-2008

Rys. 8.11. Pole geopotencjału powierzchni 500 hPa [m] w dniu 21.08.1972 r. ...... 119

Rys. 8.12. Pole geopotencjału powierzchni 500 hPa [m] w dniu 30.07.1977 r. ...... 119

Rys. 8.13. Pole geopotencjału powierzchni $500 \mathrm{hPa}[\mathrm{m}] \mathrm{w}$ dniu 08.08.1978 r. ....... 121

Rys. 8.14. Pole geopotencjału powierzchni 500 hPa [m] w dniu 8.07.1997 r. ........ 121

Rys. 8.15. Trajektorie wsteczne 96 godzinne z godz. 12 UTC dnia 4.07.1997 r. Punkty docelowe trajektorii w obszarze między 14 i $24^{\circ} \mathrm{E}$ i między 49 i $55^{\circ} \mathrm{N}$, rozmieszczone co $2^{\circ}$ szerokości i długości geograficznej na wys. 500 m n.p.t.

Rys. 8.16. Jak na rys. 8.15 - trajektorie z dnia 6.07.1997 r. 
Rys. 8.17. Jak na rys. 8.15 - trajektorie z dnia 8.07.1997 r. ................................ 123

Rys. 9.1. Pola wiatru na powierzchni $300 \mathrm{hPa}$ (linie prądu, izotachy $>20 \mathrm{~ms}^{-1}$ ) uśrednione $\mathrm{w}$ terminach występowania niżów $M E C$ na opadotwórczych odcinkach trajektorii E, C, S oraz W. Okres 1958-2008 (wg Degirmendžića i Kożuchowskiego, 2016) ........................................................................... 128

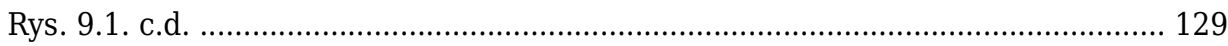

Rys. 9.2. Dywergencja $\left(\times 10^{-6} \mathrm{~s}^{-1}\right)$ na powierzchni $300 \mathrm{hPa}$ uśredniona w terminach występowania niżów $M E C$ na opadotwórczych odcinkach trajektorii E, C, S oraz W. Okres 1958-2008 (wg Degirmendžića i Kożuchowskiego, 2016)

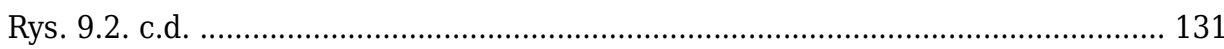

Rys. 9.3. Dywergencja związana z jet streak $\left(\times 10^{-6} \mathrm{~s}^{-1}\right)$ na powierzchni $300 \mathrm{hPa}$ uśredniona $\mathrm{w}$ terminach występowania niżów $M E C$ na opadotwórczych odcinkach trajektorii E, C, S oraz W. Okres 1958-2008

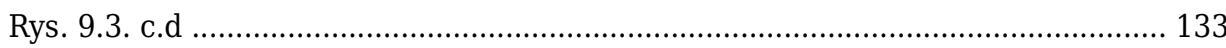




\section{Literatura}

Alpert P., Neeman B.U., Shay-El Y., 1990, Climatological analysis of Mediterranean cyclones using ECMWF data. Tellus, 42A, s. 65-77.

Alpert P., Neeman B.U., Shau-El Y., 1990, Interannual variability of cyclone tracks in the Mediterranean. Journal of Climate, 3, 12, s. 1474-1478.

Anagnostopoulou Chr., Tolika K., Flocas H., Maheras P., 2006, Cyclones in the Mediterranean region: present and future climate scenarios derived from a general circulation model (HadAM3P). Advances in Geosciences, 7, s. 9-14.

Apostol L., 2008, The Mediterranean cyclones - the role in ensuring water resources and their potential of climatic risk, in the east of Romania. Present environment and sustainable development, 2, s. 143-164.

Banacos P.C., Schultz D.M., 2005, The Use of Moisture Flux Convergence in Forecasting Convective Initiation: Historical and Operational Perspectives. Weather and Forecasting. Forecaster's Forum, 20, s. 351-366.

Bartholy J., Pongracz R., Pattantyus-Abraham M., 2009, Analyzing the genesis, intensity, and tracts of western Mediterranean cyclones. Theoretical and Applied Climatology, 96, s. 133-144.

Bartoszek K., 2006, Niże śródziemnomorskie. Przegląd Geofizyczny, 51, 1, s. 35-43.

Bebber W.J. van, 1891, Die Zugstrassen der barometrischen Minima. Meteorologische Zeitschrift, ss. 361.

Beebe R.G., Bates F.C., 1955, A Mechanism for Assisting in the Release of Convective Stability. Monthly Weather Review, 83, s. 1-10.

Bernas M., Kolendowicz L., 2013, Wpływ cyrkulacji atmosferycznej na występowanie ekstremalnych opadów atmosferycznych w Poznaniu w latach 1920-2010. Badania Fizjograficzne, 4, seria A - Geografia Fizyczna, s. 7-27.

Besselaar E.J.M., Klein Tank A.M.G., Buishand T.A., 2013, Trends in European precipitation extremes over 1951-2010. International Journal of Climatology, 33, 12 , s. $2682-2689$.

Bielec Bąkowska Z., 2010, A classification of deep cyclones over Poland (1971-2000). Physics and Chemistry of the Earth, 35, 9-12, s. 491-497.

Bluestein H. B., 1992, Synoptic-Dynamic Meteorology in Midlatitudes, I, Principles of Kinematics and Dynamics. Oxford University Press, ss. 431. 
Bogdanowicz E., Stachy J., 1998, Maksymalne opady deszczu w Polsce. Charakterystyki projektowe. Materiały Badawcze IMGW, ser. Hydrologia i Oceanologia., 23, ss. 85.

Bogdanowicz E., Stachy J., 2002, Maximum rainfall in Poland - a design approach, [w:] Snorasson A., Finnsdottir H.P., Moss M. (red.), The Extremes of the Extremes: Extraordinary Floods. IAHS Publication 227, s. 15-18.

Bogucka M., 1998, Niektóre aspekty zmienności opadów maksymalnych dobowych w Warszawie i okolicy. Acta Universitatis Lodziensis, Folia Geographica Physica, 3, s. 417-425.

Buchert L., Cebulak E., Drwal-Tylmann A., Wojtczak-Gaglik E., Kilar P., Limanówka D., Łapińska E., Mizera M., Ogórek S., Pyrc R., Winnicki W., Zawiślak T., 2013, Vademecum. Niebezpieczne zjawiska meteorologiczne. Geneza, skutki, częstość występowania. IMGW PIB, Warszawa. http://www.imgw.pl/attachments/ /1605_vademecum_wiosna_lato.pdf

Cahynova M., Huth R., 2009, Long-term trends in the frequency of atmospheric circulation types in European regions. Geophysical Abstracts, 11, EGU 2009-7543-1, EGU General Assemby 2009.

Cebulak E., 1992, Maksymalne opady dobowe w dorzeczu górnej Wisły. Zeszyty Naukowe UJ, Prace Geograficzne, 90, s. 80-96.

Cebulak E., Pyrc R., 2006, Metody opracowania zdarzeń ekstremalnych na przykładzie opadów atmosferycznych o natężeniu $>100 \mathrm{~mm} /$ dobę $w$ dorzeczu górnej Wisły w XX i XXI wieku, [w:] Maciejewski M., Ostojski M. (red.), Zagrożenia środowiska naturalnymi zjawiskami ekstremalnymi. Monografie IMiGW, Warszawa, s. 9-26.

Czarnecka M., Nidzgorska-Lencewicz J., 2012, Wieloletnia zmienność sezonowych opadów w Polsce. Woda-Środowisko-Obszary Wiejskie, 12, 2 (38), s. 45-60.

Dankers R., Hiederer R., 2008, Extreme Temperatures and Precipitation in Europe: Analysis of a High-Resolution Climate Change Scenario. European Commission, Joint Research Centre, Office for Official Publications of the European Communities. http://ies.jrc.ec.europa.eu/ .

Defant A., 1926, Wetter und Wettervorhersage (Synoptische Meteorologie). Franz Deuticke, Lepzig und Wien, ss. 346.

Degirmendžić J., 2011, Wpływ górnotroposferycznych prąów strumieniowych na rozkład przestrzenny niżów barycznych nad Europa. Wydawnictwo UŁ, ss. 332.

Degirmendžić J., Kożuchowski K., 2006, O drogach i kierunkach adwekcji mas powietrza nad obszar Polski, [w:] Trepińska J., Olecki Z., (red.) Klimatyczne aspekty środowiska geograficznego. Instytut Geografii i Gospodarki Przestrzennej UJ, Kraków, s. 339-350.

Degirmendžić J., Kożuchowski K., 2014, Sezonowe wahania liczby niżów śródziemnomorskich $w$ Europie Środkowo-Wschodniej. Przegląd Geofizyczny, LVIX, 1-2, s. 5-18.

Degirmendžić J., Kożuchowski K., 2015a, Precipitation of the Mediterranean origin in Poland - its seasonal and long-term variability. Quaestiones Geographicae 34(1), s. 37-53. 
Degirmendžić J., Kożuchowski K., 2015b, The Mediterranean cyclones, precipitable water and precipitation in Poland. Geographia Polonica (w druku).

Degirmendžić J., Kożuchowski K., 2015c, Szlaki niżów śródziemnomorskich nad Europa Środkowo-Wschodnią a opady w Polsce. Przegląd Geograficzny, 87, 3, s. 377-397.

Degirmendžić J., Kożuchowski K., 2016, Aktywność niżów śródziemnomorskich nad Polska a cyrkulacja w górnej i środkowej troposferze. Przegląd Geofizyczny, LXI, 1-2, s. 3-30.

Degirmendžić J., Kożuchowski K., Wibig J., 2000, Epoki cyrkulacyjne XX wieku i zmienność typów cyrkulacji atmosferycznej w Polsce. Przegląd Geofizyczny, XLV, 3-4, s. 221-238.

Degirmendžić J., Walisch M., Szmidt A., 2014, Pola opadów w Polsce związane z niżami $\mathrm{Vb}$ van Bebbera. Acta Universitatis Lodziensis, 13, s. 3-15.

Dimitrieev A.A., Belyazo V.A., 2006, Kosmos, planetarnaya klimaticheskaya izmenchivost' i atmosfera polarnykh regionov. Gidrometeoizdat, St. Petersburg, ss. 358.

Dubicka M., 1991, Opady atmosferyczne we Wrocławiu i ich zwiazek z cyrkulacja atmosferyczna. Prace Instytutu Geograficznego, seria A. Geografia Fizyczna, VI, Wydawnictwo UWr., s. 55-84.

Fink A. H., Brücher T., Ermert V., Krüger A., Pinto J. G., 2009, The European Storm Kyrill in January 2007, Synoptic Evolution, Meteorological Impacts and Some Considerations with Respect to Climate Change. Natural Hazards and Earth System Sciences, 9, s. 405-423.

Flocas A. H., Simmonds I., Kouroutzoglou J., Keay K., Hatzaki M., Bricolas V., Asimakopoulos D., 2010, On Cyclonic Tracks over Eastern Mediterranean. Journal of Climate, 23, s. 5243-5257.

Fortuniak K., 2003, Miejska wyspa ciepła. Podstawy energetyczne, studia eksperymentalne, modele numeryczne i statystyczne. Wydawnictwo UŁ, Łódź, ss. 233.

Girs A.A., 1971, Mnogoletnije kolebania atmosfernoj cirkulacii i dolgosrocnyje gidrometeorologiceskije prognozy. Gidrometeoizdat, Leningrad, ss. 280.

Glossary of American Meteorological Society, 2012, „Precipitable water”. http://glossary.ametsoc.org/wiki/Precipitable_water.

Gordon A., Grace W., Schwerdtfeger P., Byron-Scott R., 1998, Dynamic meteorology: a basic course. Oxford University Press, New York, ss. 325.

Grela J., Słota H., Zieliński J. (red.), 1997, Monografia powodzi, lipiec 1997. Wydawnictwo IMiGW., Warszawa.

Hann J., 1906, Lehrbuch der Meteorologie. Chr. Herm. Tauchnitz. Leipzig. ss. 642.

Harris I., 2014, NCEP/NCAR Reanalysis, Climatic Research Unit, University of East Anglia, http://www.cru.uea.ac.uk/cru/data/ncep/ (dostęp: listopad 2014)

Hess P., Brezowsky H., 1952, Katalog des Grosswetterlagen Europa. Berichte desDeutschen Wetterdienstesin der US Zone. 33, Bad Kissingen. 
HYSPLIT - Hybrid Single Particle Lagrangian Integrated Trajectory Model, ARL NOAA, http://ready.arl.noaa.gov/hypub-bin/trajtype.pl?runtype=archive (dostęp: Maj 2015).

Ivanov M.A., Evtimov S.N., 2010, 1963: the break point of the Northern Hemisphere temperature trend during the twentieth century. International Journal of Climatology, 30, s. 1738-1746.

Kalnay E., Kanamitsu M., Kistler R., Collins W., Deaven D., Gandin L., Iredell M., Saha S., White G., Woollen J., Zhu Y., Leetmaa A., Reynolds R., Chelliah M., Ebisuzaki W., Higgins W., Janowiak J., Mo K. C., Ropelewski C., Wang J., Jenne R., Joseph D., 1996, The NCEP/NCAR 40-Year Reanalysis Project. Bulletin of the American Meteorological Society, 77, s. 437-471.

Kaszewski B., 2012, Zastosowanie typologii cyrkulacji atmosferycznej $w$ badaniach klimatologicznych w Polsce na poczatku XXI wieku, [w:] Bielec Bąkowska Z., Łupikasza E., Widawski A. (red.), Rola cyrkulacji atmosfery w kształtowaniu klimatu. Wydawnictwo Wydziału Nauk o Ziemi UŚ, Sosnowiec, s. 53-66.

Kendrew W.G., 1930, Climate. A treatise on the principles of weather and climate. The Clarendon Press. Oxford, ss. 329.

Kirschenstein M., 2013, Zmienność temperatury powietrza i opadów atmosferycznych $w$ Polsce północno-zachodniej. Wydawnictwo Naukowe Akademii Pomorskiej, Słupsk, ss. 238.

Kłysik K., Fortuniak K., 1993, Maksymalne opady dobowe w środkowej Polsce. Przegląd Geograficzny, LXIV, 1-2, s. 97-110.

Köppen V., 1882, Monatliche Übersichten der Seewarte 1877 and Osterreich. Meteorologische Zeitschrift, ss. 257.

Kosiba A., 1972, Klimat Wrocławia w 1962 roku. Acta UWr., Studia Geograficzne, Prace Obserwatorium Meteorologicznego, 19.

Kożuchowski K., 1993, Makrotypy ogólnej cyrkulacji atmosfery a główne typy cyrkulacji nad Polską. Przegląd Geofizyczny, 38, 3-4, s. 241-247.

Kożuchowski K., 2003, Cyrkulacyjne czynniki klimatu Polski. Czasopismo Geograficzne, 74 (1-2), s. 93-105.

Kożuchowski K., 2010, Klimat Polski. Nowe spojrzenie. Wydawnictwo Naukowe PWN, Warszawa, ss. 293.

Kożuchowski K., 2015a, Obfitość opadów w Polsce $w$ przebiegu rocznym. Przegląd Geofizyczny, 60, 1-2, s. 27-38.

Kożuchowski K., 2015b. Zawartość wilgoci w atmosferze i opady w Polsce. Przegląd Geofizyczny (w druku).

Kożuchowski K., Wibig J., 1988, Kontynentalizm pluwialny w Polsce: zróżnicowanie geograficzne i zmiany wieloletnie. Acta Geographica Lodziensia, 55. ss. 102.

Kundzewicz Z.W., Radziejewski M., Pińskwar I., 2006, Precipitation extremes in the changing climate of Europe. Climate Research, 31, s. 51-58.

Lenart W., 1983, Transport pary wodnej nad terytorium Polski. Przegląd Geofizyczny, 28, 3-4, s. 281-290. 
Lorenc H., Olecka A., 2006, Tendencje występowania opadów o dużym natężeniu w Polsce, [w:] Współczesne problemy klimatu Polski - fakty i niepewności. IMiGW, Warszawa, s. 23-36.

Loughe A. F., Lai C. C., Keyser D., 1994, A technique for diagnosing three-dimensional ageostrophic circulation in baroclinic disturbances on limited area domains. Monthly Weather Review, 123, s. 1476-1504.

Łupikasza E., 2010a, Genetyczne typy opadów ekstremalnych w sezonie letnim w Polsce oraz ich zmienność wieloletnia w okresie 1951-2007, [w:] Bednorz E. (red.), Klimat Polski na tle klimatu Europy. Warunki termiczne i opadowe. Bogucki Wydawnictwo Naukowe, Poznań, s. 131-145.

Łupikasza E., 2010b, Spatial and temporal variability of extreme precipitation in Poland in the period 1951-2006. International Journal of Climatology, 30, s. 991-1007.

Łupikasza E., 2013, Typy genetyczne opadów ekstremalnych $w$ Europie oraz ich uwarunkowania synoptyczne (1951-2008). Prace Wydziału Nauk o Ziemi Uniwersytetu Śląskiego, 81, Katowice, ss. 302.

Łupikasza E., Hansel S., Matschullat J., 2011, Regional and seasonal variability of extreme precipitation trends in southern Poland and central-eastern Germany 1951-2006. International Journal of Climatology, 31, s. 2249-2271.

Majewski G., Przewoźniczuk W., Kleniewska M., 2010, Warunki opadowe na stacji meteorologicznej Ursynów SGGW w latach 1960-2009. Przegląd Naukowy - Inżynieria i Kształtowanie Środowiska 2, 48, s. 3-22.

Malik K. M., Taylor P. A., 2011, Characteristics of Moisture Flux Convergence over the Mackenzie River Basin for Water Years 1991-2008. Atmosphere-Ocean, 49, 3, s. 279-288.

Malinowska M., Miętus M., 2010, Opady o dużym natężeniu w Gdyni i ich uwarunkowania atmosferyczne, [w:] Ciupa T., Suligowski R. (red.), Woda w badaniach geograficznych. Instytut Geografii Uniwersytetu Jana Kochanowskiego, Kielce, s. 49-58.

Marosz M., Wójcik R., Biernacik D., Jakusik E., Pilarski M., Owczarek M., Miętus M., 2011, Zmienność klimatu Polski od połowy XX wieku. Rezultaty projektu KLIMAT. Prace i Studia Geograficzne, 47, s. 51-66.

Martyn D., 2000, Klimaty kuli ziemskiej. Wydawnictwo Naukowe PWN, Warszawa, ss. 360 .

Morozowska I., 1987, Prognoza obfitych opadów w Polsce związanych z przemieszczaniem się cyklonów południowoeuropejskich. Wiadomości IMGW, 21, 4, s. 63-78.

Mundelsee M., Börngen M., Tetzlaff G., Grünewald U., 2004, Extreme floods in central Europe over the past 500 years: Role of cyclone pathway "Zugstrasse Vb". Journal of Geophysical Research, 109, D23101.

Murray, R. J., Simmonds I., 1991, A numerical scheme for tracking cyclone centres from digital data. Part I: Development and operation of the scheme. Australian Meteorological Magazine, 39, s. 155-166. 
Mycielska H., Michalczewski J., 1972, Meteorologiczne przyczyny wezbrania $w$ lipcu 1970, [w:] Powódź w lipcu 1970, Wydawnictwo Komunikacji i Łączności, Warszawa, s. 17-42.

Nakamura H., 1993, Horizontal Divergence Associated with Zonally Isolated Jet Streams. Journal of Atmospheric Sciences, 50, s. 2310-2313.

Niedźwiedź T. (red.), 2003a. Słownik meteorologiczny. PTGeof.-IMiGW, Warszawa, Ss. 496.

Niedźwiedź T., 2003b, Extreme precipitation in Central Europe and its synoptic background. Papers on Global Change, 10, s. 15-30.

Nissen K. M., Ulbrich U., Leckebusch G. C., 2013, Vb cyclones and associated rainfall extremes over Central Europe under present day and climate change conditions. Meteorologische Zeitschrift, 22, 6, s. 649-660.

O’Neill P., 1997, Chemia środowiska. Wydawnictwo Naukowe PWN, Warszawa, Ss. 308.

Osuchowska-Klein B., 1978, Katalog typów cyrkulacji atmosferycznej. Wydawnictwo Komunikacji i Łączności, Warszawa, ss. 192.

Otop I., 2004, Maksymalne dobowe opady atmosferyczne $w$ Karkonoszach $w$ drugiej połowie XX wieku, [w:] Geoekologicke problemy Krkonos. Sborn. Mez. Ved. Konf., Szklarska Poręba, s. 25-29.

Panofsky H. A., Brier G. W., 1958, Some application of Statistics to Meteorology. The Pennsylvania State University, ss. 224.

Peixoto J. P., Oort A. H., 1992, Physics of climate. American Institute of Physics, New York, ss. 521.

Pietkiewicz A. 1889, Stosunki opadu atmosferycznego w Warszawie. Pamiętnik Fizjograficzny, IX, s. 159-194.

Pinto J. G., Zacharis S., Fink A. H., Leckebusch G. C., Ulbrich U., 2009, Factors contributing to the development of extreme North Atlantic cyclones and their relationship with the NAO. Climate Dynamics, 32, s. 711-737.

Piotrowski P., 2009, Obiektywna metoda klasyfikacji cyrkulacji atmosferycznej dla Polski. Acta Universitatis Lodziensis. Folia Geographica Physica, 10, Wydawnictwo UŁ, ss. 216.

Projekt KLIMAT, 2010, Wpływ zmian klimatu na środowisko, gospodarkę i społeczeństwo (zmiany, skutki i sposoby ich ograniczania, wnioski dla nauki, praktyki inżynierskiej i planowania gospodarczego), Zadanie nr 4: Klęski żywiołowe a bezpieczeństwo wewnętrzne kraju. IMGW, Warszawa, http://klimat.imgw.pl/ /wp-content/uploads/2011/02/zad.4_R2010.pdf (dostęp: lipiec 2014)

Projekt KLIMAT, 2009, Wpływ zmian klimatu na środowisko, gospodarkę i społeczeństwo, Zadanie nr 1: Zmiany klimatu i ich wpływ na środowisko naturalne Polski oraz określenie ich skutków ekonomicznych. IMiGW, Warszawa, http://klimat.imgw.pl/wp-content/uploads/2010/09/zad.1.r2009web.pdf (dostęp: lipiec 2014)

Prokop P., 2006, Maksymalne opady oraz czas ich trwania na świecie i $w$ Polsce. Przegląd Geofizyczny, LI, 2, s. 147-160. 
Rzepa M., 2004, Najwyższe dobowe, pięciodniowe i dziesięciodniowe sumy opadów atmosferycznych $w$ Łodzi w latach 1903-2003. Acta Geographica Lodziensia, 89 , s. $87-100$.

Sauer E. L., 1995, The effect of 300-mb divergence on surface cyclogenesis. Naval Postgraduate School, Monterey, California, maszynopis powielany, ss. 131.

Sechrist F. S., Whittaker T. M., 1979, Evidence of jet streak Vertical Circulations. Monthly Weather Review, 107, s. 1014-1021.

Sepp M., 2011, Regime shift in atmospheric circulation in the Baltic Sea region (in Eston.). Publicationes Instituti Geographici Universitatis Tartuenesis, 109, s. $72-89$.

Serreze M.C., 2009, Northern Hemisphere Cyclone Locations and Characteristics from NCEP/NCAR Reanalysis Data. Boulder, Colorado USA: National Snow and Ice Data Center. Digital media, ftp://sidads.colorado.edu/pub/DATASETS/ /atmosphere/nsidc0423_cyclone_ncep_ncar_reanalysis/(dostęp: wrzesień 2011)

Sidorenkov N.S., Svirenko P.I., 1983, K voprosu o mnogoletnich kolebanijach atmosfernoj cirkulacyi. Meteorologija i Gidrologia, 11.

Siwek K., 2010, Występowanie na Lubelszczyźnie dobowych sum opadu atmosferycznego >100 mm i ich uwarunkowania cyrkulacyjne (1951-2000). Annales UMCS, Seria B., LXV, 2, s. 117-125.

Skowera B., Wojkowski J., 2003, Changes in Hydrothermal Conditions in Poland in the Period 1931-1990. Acta Universitatis Wratislaviensis 2542, Studia Geograficzne 75, s. 262-267.

Sobik M., Błaś M., 2010, Wyjątkowe zdarzenia meteorologiczne [w:] Migoń P. (red.), Wyjątkowe zdarzenia przyrodnicze na Dolnym Śląsku. Uniwersytet Wrocławski, Wrocław, s. 35-59.

Stach A., 2009, Analiza struktury przestrzennej i czasoprzestrzennej maksymalnych opadów dobowych $w$ Polsce $w$ latach 1956-1980. Wydawnictwo Naukowe UAM, seria Geografia, 85, Poznań. ss. 323.

Suligowski R., 2004, Struktura czasowa i przestrzenna opadów atmosferycznych $w$ Polsce. Próba regionalizacji. Prace Instytutu Geografii Akademii Swiętokrzyskiej, Kielce, 12, ss. 112.

Suligowski R. 2013, Opady maksymalne na potrzeby hydrologii. SGGW. pre_suligowski.pdf (dostęp: maj 2015)

Surova N.AQ., 1984, Sovremennyje izmenenija klimata na Bolszom Kaukazie. Trudy Vysokogronogo Geofiziczeskogo Instituta, 52.

Świątek M., 2009, Wpływ cyrkulacji atmosferycznej na zmienność opadów na polskim wybrzeżu Bałtyku. Rozprawy i Studia DCCCXXVI, Wydawnictwo Naukowe USz., Szczecin, ss. 150.

Świątek M., 2013a, Advection of air masses responsible for extreme rainfall totals in Poland, and exemplified by catastrophic floods in Raciborz (July 1997) and Dobczyce (May 2010). Acta Agrophysica, 20 (3), s. 481-494. 
Świątek M., 2013b, Związek opadów atmosferycznych na polskim wybrzeżu Bałtyku $z$ położeniem niżów barycznych nad Europa. Przegląd Geograficzny, 85, 1, s. 87-102.

Tamulewicz J., 1993, Struktura pola opadów atmosferycznych Polski w okresie 1951-1980. Wydawnictwo Naukowe UAM, Poznań, ss. 182.

Twardosz R., 1997, Ekstremalne sumy dobowe opadów w Krakowie, [w:] Ekstremalne zjawiska meteorologiczne, hydrologiczne i oceanograficzne. Materiały Sympozjum Jubileuszowego PTGeof., 12-14.11.1997, Warszawa, s. 161-163.

Twardosz R., 2000, Wieloletnia zmienność sum dobowych opadów w Krakowie w powiązaniu z sytuacjami synoptycznymi. Prace Geograficzne, 105, IG UJ, s. 22-105.

Twardosz R., 2007, Opady atmosferyczne [w:] Matuszko D. (red.), Klimat Krakowa w XX i XXI wieku. Wydawnictwo IGiPZ UJ, Kraków, s. 127-138.

Uccellini L. W., Kocin P. J., 1987, The Interaction of jet streak Circulation during Heavy Snow Events along the Coast of the United States. Weather and Forecasting, 2, s. 289-308.

Ulbrich U., Brücher T., Fink A. H., Leckebusch G. C., Kruger A., Pinto J. G., 2003, The central European floods of August 2002, Part 2 - Synoptic causes and considerations with respect to climatic change. Weather, 58, s. 434-442.

Ustrnul Z., Czekierda D., 2009, Atlas ekstremalnych zjawisk meteorologicznych oraz sytuacji synoptycznych $w$ Polsce. Wydawnictwo IMiGW, Warszawa.

H.M.S.O., 1962, Weather in the Mediterranean. 1, General meteorology. $2^{\text {nd }}$ ed, Her Majesty's Stationery Office, ss. 362.

Wibig J., 1999a, Cyrkulacja atmosferyczna nad Europa na powierzchni izobarycznej $500 \mathrm{hPa}$. Część II: Wiosna, lato, jesień. Przegląd Geofizyczny, XLIV 1-2, s. 25-38.

Wibig J., 1999b, Cyrkulacja atmosferyczna nad Europa na powierzchni izobarycznej 500 hPa. Częśc I: Zima. Przegląd Geofizyczny, XLIV, 1-2, s. 15-24.

Wibig J., 2001, Wpływ cyrkulacji atmosferycznej na rozkład przestrzenny anomalii temperatury i opadów w Europie. Wydawnictwo UŁ, Łódź, ss. 208.

Wibig J., 2008, Transport of Water Vapor over Europe and its Relation to Circulation Patterns, [w:] Media Session at the $7^{\text {th }}$ Annual EMS Meeting, San Lorenzo de El Escorial, Spain, 1-5 October 2007, European Meteorological Society, Media Committee, Wydawnictwo Environmental Agency of the Republic of Slovenia, Ljubljana, ss. 2.

Wibig J., 2009, Variability of daily precipitation totals in Poland (1951-2000). Geographia Polonica, 82, s. 21-32.

Wibig J., Fortuniak K., 1998, The extreme precipitation conditions in the period 1931-1995, [w:] Klimat i bioklimat miast. Acta Universitatis Lodziensis, Folia Geographica Physica, 3, s. 241-250. 
Wibig J., Siedlecki M., 2007, Przestrzenny i czasowy rozkład zawartości wody opadowej $w$ atmosferze nad Europa (1958-2005), [w:] Piotrowicz K., Twardosz R. (red.), Wahania klimatu w różnych skalach przestrzennych i czasowych. Wydawnictwo UJ., Kraków, s. 195-204.

Woś A., 1994, Klimat Niziny Wielkopolskiej. Wydawnictwo Naukowe UAM, Poznań, Ss. 192.

Woś A., 1996, Struktura sezonowa klimatu Polski. Bogucki Wydawnictwo Naukowe, Poznań, ss. 144.

Wrona B., 2008, Meteorologiczne i morfologiczne uwarunkowania ekstremalnych opadów atmosferycznych $w$ dorzeczu górnej i środkowej Odry. Materiały Badawcze IMiGW, seria Meteorologia, 41, ss. 120.

Zawora T., Ziernicka A., 2003, Precipitation variability in time in Poland in the light of multi-annual mean values (1891-2000). Acta Universitatis Wratislaviensis 2545, Studia Geogr. 75, s. 123-128.

Ziemiański M., 2002, Systemy baryczne umiarkowanych szerokości geograficznych jako wynik działania niestabilności baroklinowej, [w:] Marsz A.A., Styczyńska A., (red.) Oscylacja północnego Atlantyku i jej rola w kształtowaniu zmienności warunków klimatycznych hydrologicznych Polski. Wydawnictwo Uczelniane Akademii Morskiej, Gdynia, s. 205-214.

Ziernicka-Wojtaszek A., 2006, Zmienność opadów atmosferycznych na obszarze Polski w latach 1971-2000, [w:] Trepińska J., Olecki Z. (red.), Klimatyczne aspekty środowiska geograficznego. IGiPZ UJ. Kraków, s. 139-148.

Zmiany klimatyczne $w$ Polsce. http://poznajpogode.pl/zmiany-klimatyczne-w-polsce (dostęp: listopad 2015).

Żmudzka E., 2010, Współczesne zmiany wielkości i charakteru opadów w Tatrach, [w:] Nauka a zarządzanie obszarem Tatr i ich otoczeniem, TPN, Zakopane, 1, s. 157-164. 



\section{Summary - Mediterranean Cyclones as a Factor of the Climate of Poland}

\section{Aims}

The preliminary aim of the climatological analysis of the activity of Mediterranean cyclones in Europe is to define the object of study. The type of atmospheric circulation is defined: a Mediterranean cyclone in Central and Eastern Europe (MEC - Mediterranean European Cyclone), i.e. a cyclonic system moving along a trajectory which originates in the Mediterranean Sea basin and reaches an adequately defined area of Europe. As a result of their activity, MECs were assigned precipitation of Mediterranean origin in Poland (Mediterranean Cyclonal Precipitation - MCP).

In Polish climatological literature, we do not yet have a synthetic description of $M E C$ cyclones. They have been, nonetheless, mentioned in a number of works, the most complete synthesis of information on Mediterranean cyclones being contained in Bartoszek's article (2006). However, we do not yet know how often MECs appear in Central and Eastern Europe, what their actual trajectories are (is the 'classic' Vb track the only one?), whether the incidence of $M E C$ cyclones is seasonal in nature, and, finally: are we facing longterm changes in the frequency of $M E C$ cyclones?

Furthermore, there are a number of questions concerning precipitation of Mediterranean origin, its overall volume, its share in the precipitation total in the area of Poland as well as its spatial distribution and long-term changes. It should also be checked whether the thesis is valid that a significant amount of $M C P$ precipitation is determined by the moisture content in the air which participates in the MEC cyclonic circulation. An important issue is also the thermal and moisture structure of MECs - due to their cyclogenesis area and peculiar trajectory, are they distinguished by any specific characteristics?

This study aims to elaborate a climatological description of MEC cyclones: an assessment of the frequency of their occurrence as well as their se- 
asonal and long-term variability. The study also aims at a climatological description of precipitation of Mediterranean origin in Poland.

Several research assumptions have been verified in the study:

1) Mediterranean cyclones rarely occur in Central Europe;

2) the incidence of $M E C s$ is characterized by seasonal variability;

3) $M E C$ cyclones reach Central and Eastern Europe along characteristic but different tracks;

4) precipitation of Mediterranean origin in Poland is characterized by high intensity and is a considerable part of total precipitation;

5) the spatial distribution of $M C P$ in the area of Poland depends on the trajectory of $M E C$;

6) $\mathrm{MCP}$ is formed under conditions of elevated, higher than the average moisture content in the atmosphere;

7) MECs and the related high precipitation appear during periods of prevalence of meridional macro-circulation forms;

8) $M E C$ cyclones and $M C P$ precipitation belong to the class of extreme hydro-meteorological phenomena, and their frequency and intensity increase with progressing global warming.

\section{Data}

The study uses the database "Northern Hemisphere Cyclone Locations and Characteristics from NCEP/NCAR Reanalysis Data", containing the list of low pressure systems developing over the Northern Hemisphere in the period between 1.01.1958 and 31.12.2008 (Serreze, 2009). In order to select the Mediterranean cyclones passing from the Mediterranean Sea, the Black Sea or the Azov Sea to Central Europe, the following two criteria were used:

1) at any stage of the development of a cyclonic system, its centre is located over the basins of the Mediterranean Sea, the Black Sea or the Azov Sea;

2) at a later stage of development, the centre of the cyclone moves over an area lying no farther than $350 \mathrm{~km}$ from the Polish borders.

As a result 351 systems meeting the above conditions were selected in the years 1958-2008.

The MEC trajectories were grouped into classes. In the classification procedure, the trajectory path running from the Mediterranean Sea or the Black Sea to Central and Eastern Europe was taken into consideration. 
As a result of the procedure used, 12 types of trajectories were distinguished along which Mediterranean cyclones move from over the Mediterranean Sea, the Black Sea or the Azov Sea to Central or Eastern Europe:

- eastern types: E (E1, E2) (trajectories running east of Poland: they correspond to van Bebber's Vb track),

- western types: W (W1, W2) (trajectories running west of Poland),

- central types: $\mathrm{C}(\mathrm{C} 1, \mathrm{C} 2)$ (trajectories passing centrally through the territory of Poland),

- southern types: S (S1, S2) (trajectories running south of Poland),

- Black Sea types (BS - Black Sea):

-BSS (point of cyclolysis south of Poland),

- BSN (point of cyclolysis north of Poland),

- BSE (trajectories running east of Poland),

- BSC (trajectories entering the territory of Poland).

The analysis of precipitation is based on the series of daily precipitation totals derived from 66 meteorological stations distributed evenly throughout the territory of Poland. The series cover the years 1958-2008. The data were obtained from the Institute of Meteorology and Water Management (IMGW). It was verified how MECs modify the thermal and moisture conditions in the lower troposphere over Europe. Furthermore, the $500 \mathrm{hPa}$ geopotential field was characterized as well as the wind and divergence field in the upper troposphere associated with MECs situated on the tracks passing through Central and Eastern Europe. The following data series were used for the analysis:

- PW content in the atmosphere [mm] (PW - Precipitable water) as well as specific humidity at the $1000 \mathrm{hPa}$ surface $\left[\mathrm{g} \mathrm{kg}^{-1}\right]$,

- air temperature at a height of $2 \mathrm{~m}$ AGL $\left[{ }^{\circ} \mathrm{C}\right]$,

- wind components at the 1000 and $300 \mathrm{hPa}$ surfaces [m s${ }^{-1}$ ],

- geopotential of the 500 and $300 \mathrm{hPa}$ surfaces [m].

The series come from the NCEP-NCAR Reanalysis database (Kalnay et al. 1996) and are available on the website of the Climate Research Unit, University of East Anglia. The data are characterized by 6-hourly temporal resolution on a $2,5^{\circ} \times 2,5^{\circ}$ grid. They refer to the period 1958-2008.

The influence of macro-scale circulation factors on the frequency of occurrence of $M E C$ cyclones was determined. In order to do this, information on macro-circulation types taken from Vangengeim-Girs classification and included in Dmitriev's and Belyazo's catalogue (2006) and its update was used. 


\section{Results}

The study performed makes it possible to resolve the research hypotheses. Below are the arguments supporting the hypotheses (with one notable exception):

1. Mediterranean cyclones rarely occur in Central Europe. The statistics for the MECs confirm that the frequency of Mediterranean cyclones over Central and Eastern Europe is relatively small: there are on average 7 such cases annually, and the likelihood of the occurrence of a $M E C$ on a given day of the year is less than $2 \%$.

2. It was stated that the incidence of MECs is characterized by seasonal variability. This variability is characterized by 6 -month cycle with maxima in April and October. The spring maximum is the most developed. Mediterranean cyclones rarely happen in July, although then the risk of extremely high precipitation associated with them in Central Europe is particularly great.

3. $M E C$ cyclones reach Central and Eastern Europe along characteristic but different tracks. A number of classes (types) of such trajectories were separated. Cyclones originating over the Mediterranean Sea basin most commonly use the type $C$ track, i.e. the one passing centrally through Poland. The track running east of Poland (type E), which roughly corresponds to the Vb track distinguished by Van Bebber, is also quite highly frequented.

4. Precipitation of Mediterranean origin in Poland is characterized by high intensity and is a considerable part of total precipitation. By analyzing the average values, it was stated that there is a relative predominance of MCP intensity over the average intensity of precipitation in Poland. The share of $M C P$ in the total precipitation in Poland can be considered high, given the low frequency of MECs. The average intensity of "Mediterranean precipitation" (amount of MCP precipitation/rainy day) accounts for approximately $150 \%$ of the average intensity of the total precipitation in Poland. Precipitation associated with the activity of Mediterranean cyclones accounts for about $10 \%$ of the total amount of precipitation occurring in Poland. In April (6-10.04), Mediterranean precipitation represents nearly 1/3 of the total precipitation in Poland. The share of $M C P$ in precipitation totals increases with the amount of these totals. A daily precipitation of $>80 \mathrm{~mm}$ contains on average nearly one fourth of $M C P$. 
5. The spatial distribution of $M C P$ in the area of Poland depends on the trajectory of $M E C s . M C P$ higher than average intensity of the total precipitation is associated with cyclones passing from the Mediterranean Sea through Poland (class C), to the east (class E) and south (class S) of the Poland's borders. The highest MCP occurs on the left (western) side of the meridionally running tracks: CW (western branch of the $C$ track), CE (eastern branch of the $C$ track) and $E$, in the zones of prevalence of the northerly and easterly cyclonic circulation components. In the south east of Poland, the highest MCP precipitation levels are also associated with class $S$ cyclone tracks; they occur north of the track. The spatial distribution of $M C P$ in the territory of Poland is in particular determined by the course of $C$ track. The highest average $M C P$ totals (> $10 \mathrm{~mm} /$ day) occur in the mountains and their foreland, being related to the activity of $M E C$ on the eastern and southern tracks in the Carpathians, while in the Sudetes to the cyclones on the CW and CE central tracks. Thus it can be concluded that the Oder river basin is threatened with the highest precipitation associated with MECs on the central track, whereas the Vistula basin - with cyclones on the eastern and southern tracks.

6. $M C P$ is formed under conditions of elevated, higher than the average moisture content in the atmosphere. As it turns out, however, the impact of the moisture content in the atmosphere on the amount of precipitation is not too great. Under the influence of Mediterranean cyclones, the moisture content in the atmosphere over Poland increases on average by ca $15 \%$; the largest average increase of $P W$ is brought about by cyclones moving along the western track (22\%), the smallest by cyclones on the eastern track (5\%). The mean daily precipitation totals associated with MECs represent on average from 11\% (precipitation associated with the western track) to $37 \%$ (precipitation associated with the eastern track) of the average moisture content in the atmosphere. Extremely high $M C P$, however, represents a multiple of the precipitable water column - it may be even 8-9 times higher. All identified MCP precipitation shows a significant, but not strong correlation with the precipitable water content. Changes in the moisture content account only for $10 \%$ of the variability of $M C P$ totals. $M E C$ cyclones control the influx of moisture from over the Mediterranean Sea and form a "stain" of moisture located over Poland and east of its area as a result of moisture flux convergence taking place there. 
7. MECs and the related high precipitation appear during periods of prevalence of meridional macro-circulation forms. Cyclones in the Mediterranean Sea basin and MECs on most rainfall-efficient sections of their tracks in Europe are most commonly associated with the E meridional macro-circulation form (more than 2/3 occur during the prevalence of $\mathrm{E}$ macro form). The relationship of $M E C$ with the $\mathrm{E}$ macro-circulation form is confirmed by their long-term course. The correlation of annual incidence of MECs and $E$ macro forms is significant, although not very high $(r=0.33)$. The 1980 s drop in the frequency of MECs coincides with the declining frequency of the $E$ form. During fifty years, the annual number of MECs decreased by more than a half, while the number of days with the E macro form - by about 35\%. MEC cyclones are also accompanied by characteristic differences in temperature over Europe, proving the prevalence of meridional circulation forms. The average values of temperature differences in the cyclone latitudinal cross-section are about $7^{\circ} \mathrm{C}$. The air temperature at $2 \mathrm{~m}$ AGL increases from the west to the east. The amount of precipitation of Mediterranean origin in Poland shows weak correlation with the intensity of cold advection, i.e. with the negative temperature anomalies in the western sectors of MECs.

It has been demonstrated that it is circulation conditions in the upper troposphere, i.e. the upper trough over western Europe and a jet streak embedded close to its axis in a subtropical jet stream, that particularly contribute to the development of MECs situated on most rainfall-efficient sections of their trajectories. Above the sections of trajectories $\mathrm{E}, \mathrm{C}, \mathrm{W}$ and $\mathrm{S}$ there is a strong positive divergence aloft with average values characteristic of cyclonic bombs developing over the area of Europe and the eastern Atlantic. The highest values of divergence accompany the class $E$ cyclones.

8. $M E C$ cyclones and $M C P$ precipitation belong to the class of extreme hydro-meteorological phenomena, and their frequency and intensity increase with progressing global warming. Some absolute maxima of daily precipitation totals in Poland are of Mediterranean origin. Torrential precipitation and flooding associated with the activity of MECs, besides a relatively low incidence of such synoptic situations, allow to include them in the class of extreme weather events.

In the period 1958-2008, the total number of identified Mediterranean cyclones reaching Central and Eastern Europe decreased. The 
annual number of MECs shows a significant downward trend (-3.7/50 years as against an average of 6.9$)$. The biggest decline in incidence concerns cyclones travelling the eastern track $(\sim \mathrm{Vb})$. In the analyzed period, the annual MCP totals in Poland decreased by $29 \mathrm{~mm}$, which accounts for $43 \%$ of their long-term average amount. The precipitation trends show a declining share of $M C P$ in the total precipitation in Poland. The multi-year course of the moisture content in the atmosphere over Poland is also characterized by a decreasing trend. In the period 1958-2008, the average annual values of PW decreased by almost $10 \%$, and that was a statistically significant change.

If MECs, and notably the related high precipitation, can be regarded as extreme weather events, the hypothesis of increasing incidence of such phenomena in the contemporary era of global warming does not find confirmation in the light of the analyses performed. The decreasing frequency of occurrence of macro-circulation forms, conducive to Mediterranean cyclones reaching Central and Eastern Europe, is a plausible explanation for the observed trends in the incidence of MECs and the amount of MCP totals. However, it should be noted that with the decreasing frequency of MECs and the decreasing moisture content in the atmosphere, the intensity of $M C P$ precipitation continued to remain throughout the studied multi-year period at a level not significantly changed, which means that the efficiency of precipitation generating processes in MECs could have been growing.

According to some climate change scenarios, the predicted Atlantic jet stream shift eastward to the continental Europe can significantly reduce the incidence of the TrM situation (according to the Großwetterlagen classification) over Western and Central Europe, and consequently limit the number of MECs, too.

Mediterranean cyclones in Central and Eastern Europe, precipitation of Mediterranean origin as well as the moisture content in the atmosphere over Poland are no doubt subject to the impact of global changes. It should be noted, however, that the direct factor in these interactions is the atmospheric circulation and its transformations on a hemispheric scale; they result in both the observed trends in Mediterranean cyclones and precipitation of Mediterranean origin, and in a significant trend of moisture content in the atmosphere, decreasing in Poland in spite of the progress of global warming. 
